Keywords: SCIX, DWPF, Titanium, Glass, Durability

Retention: Permanent

\title{
Impacts of Small Column Ion Exchange Streams on DWPF Glass Formulation: KT05 and KT06-Series Glass Compositions
}

K. M. Fox

T. B. Edwards

December 2010

Savannah River National Laboratory Savannah River Nuclear Solutions, LLC Aiken, SC 29808

Prepared for the U.S. Department of Energy under contract number DE-AC09-08SR22470.

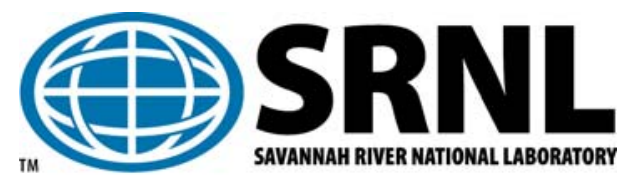




\section{DISCLAIMER}

This work was prepared under an agreement with and funded by the U.S. Government. Neither the U.S. Government or its employees, nor any of its contractors, subcontractors or their employees, makes any express or implied:

1. warranty or assumes any legal liability for the accuracy, completeness, or for the use or results of such use of any information, product, or process disclosed; or

2. representation that such use or results of such use would not infringe privately owned rights; or

3. endorsement or recommendation of any specifically identified commercial product, process, or service.

Any views and opinions of authors expressed in this work do not necessarily state or reflect those of the United States Government, or its contractors, or subcontractors.

\section{Printed in the United States of America \\ Prepared for U.S. Department of Energy}




\section{REVIEWS AND APPROVALS}

AUTHORS:

K. M. Fox, Process Technology Programs

Date

T. B. Edwards, Applied Computational Engineering and Statistics

Date

TECHNICAL REVIEW:

D. K. Peeler, Process Technology Programs

Date

APPROVAL:

C. C. Herman, Manager

Date

Process Technology Programs

F. M. Pennebaker, Manager

Date

SRNL SCIX Program

S. L. Marra, Manager

Date

Environmental \& Chemical Process Technology Research Programs

J. E. Occhipinti, Manager

Date

Waste Solidification Engineering

T. H. Huff, Manager

Date

SCIX Engineering 


\section{EXECUTIVE SUMMARY}

This report is the second in a series of studies of the impacts of the addition of Crystalline Silicotitanate (CST) and Monosodium Titanate (MST) from the Small Column Ion Exchange (SCIX) process on the Defense Waste Processing Facility (DWPF) glass waste form and the applicability of the DWPF process control models. The KT05-series glasses were selected, fabricated, and characterized to further study glass compositions where iron titanate crystals had been previously found to form. The intent was to better understand the mechanisms and compositions that favored the formation of crystals containing titanium. Formation of these crystalline phases was confirmed. Increased $\mathrm{Na}_{2} \mathrm{O}$ concentrations had little if any impact on reducing the propensity for the formation of the iron titanate crystalline phases. Other physical properties of these glasses were not measured since the intent was to focus on crystallization. Additional studies are suggested to investigate the potential impacts of $\mathrm{Al}_{2} \mathrm{O}_{3}$ and $\mathrm{K}_{2} \mathrm{O}$ on crystallization in glasses with high $\mathrm{TiO}_{2}$ concentrations.

The KT06-series glasses were selected, fabricated, and characterized to further study glass compositions that, while broader than the current projections for DWPF feeds with SCIX material, are potential candidates for future processing (i.e., the compositions are acceptable for processing by the Product Composition Control System (PCCS) with the exception of the current $\mathrm{TiO}_{2}$ concentration constraint). The chemical compositions of these glasses matched well with the target values. The chemical durabilities of all the glasses were acceptable relative to the Environmental Assessment (EA) benchmark. Minor crystallization was identified in some of the slowly cooled glasses, although this crystallization did not impact chemical durability.

Several of the KT06-series compositions had durability values that, while acceptable, were not accurately predicted by the current durability models. It was shown that for these high $\mathrm{TiO}_{2}$ concentration glasses, relatively high $\mathrm{Fe}_{2} \mathrm{O}_{3}$ concentrations combined with relatively high $\mathrm{Al}_{2} \mathrm{O}_{3}$ concentrations led to durabilities that were unpredictable. Several of the KT06-series glasses also had measured viscosity values that were not well predicted by the current model. A statistical partitioning routine showed that the measured viscosities became unpredictable by the current model when the $\mathrm{Fe}_{2} \mathrm{O}_{3}$ concentration in the glasses was less than about $8.2 \mathrm{wt} \%$ at the elevated $\mathrm{TiO}_{2}$ concentrations. The current durability and viscosity models will have to be further evaluated should compositions in these regions become necessary for DWPF processing.

Overall, the results presented for the KT06-series glasses show that $\mathrm{TiO}_{2}$ from the SCIX streams can be incorporated into DWPF-type glasses at concentrations of $6 \mathrm{wt} \%$ (in glass) without any detrimental impacts on crystallization or chemical durability that are of practical importance. The measured values for chemical durability and viscosity were acceptable for processing; however, not all of the values were predictable by the current PCCS models. Since the compositions selected for the KT06-series glasses were outside the current projections for DWPF processing with the SCIX streams (in terms of waste components other than $\mathrm{TiO}_{2}$ ), these results help identify compositional regions that, if necessary for processing, would require modifications to the current models. Additional experiments are currently underway. Once completed, all of the measured data will be reviewed and compared to model predictions to better determine whether the validation range of the DWPF process control models can be confidently extended, or whether refitting of the models will be necessary. 


\section{TABLE OF CONTENTS}

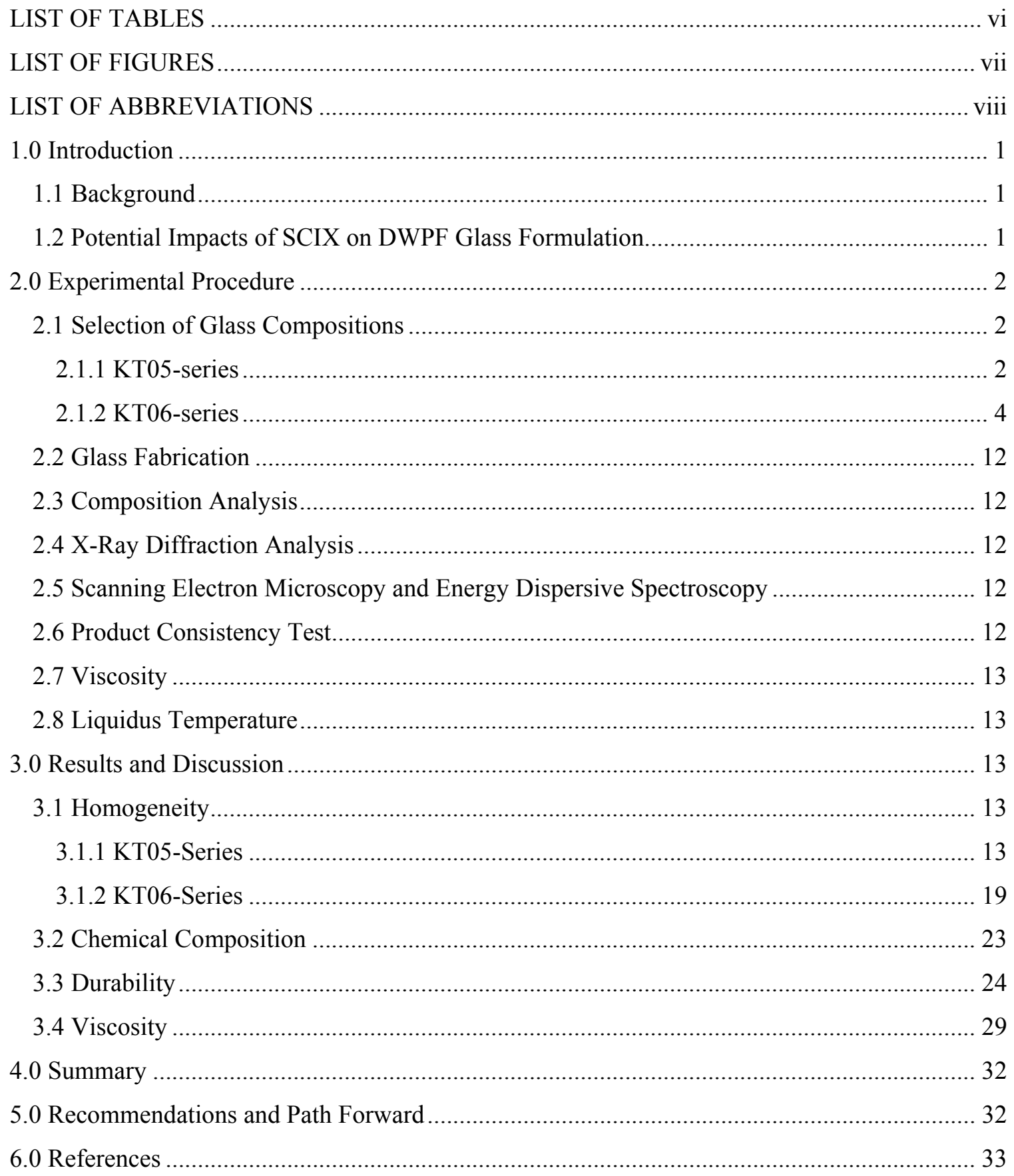




\section{LIST OF TABLES}

Table 2-1. Target Compositions (wt \%) of the KT05-Series Glasses. 3

Table 2-2. Individual Component Ranges Covering Projections of Sludge Batches 8 Through 17,

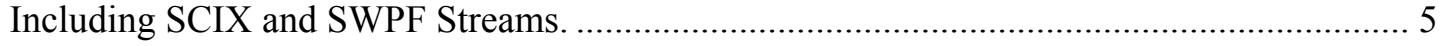

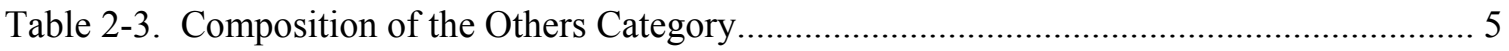

Table 2-4. Outer and Inner Layer Component Ranges for the KT06-Series Sludge Composition

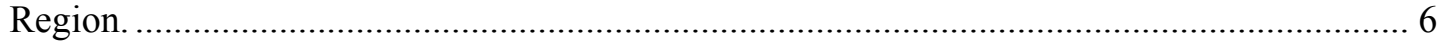

Table 2-5. Array of Candidate Frit Compositions Used in Selecting the KT06-Series Glasses. ... 7

Table 2-6. Frit Compositions Selected for the KT06-Series Glasses.......................................... 9

Table 2-7. Description of Glasses Selected for the KT06-Series. ............................................. 9

Table 2-8. Target Compositions (wt \%) of the KT06-Series Glasses. ............................................. 10

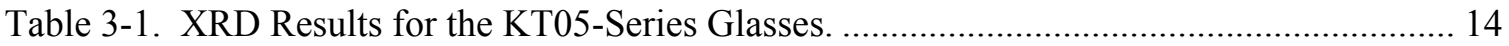

Table 3-2. XRD Results for the CCC Versions of the KT06-Series Glasses.............................. 19 


\section{LIST OF FIGURES}

Figure 2-1. Graphical Representation of the $\mathrm{Al}_{2} \mathrm{O}_{3}: \mathrm{Fe}_{2} \mathrm{O}_{3}$ Ratios of the Sludge Compositions Selected for the KT06-Series Glasses. The Plots Correspond to Sludge $\mathrm{Na}_{2} \mathrm{O}$ Concentrations of $20 \mathrm{wt} \%$ (a), $25 \mathrm{wt} \%$ (b), and $30 \mathrm{wt} \%$ (c). 8

Figure 3-1. Electron Micrograph and Corresponding EDS Spectra of the Quenched Version of Glass KT05-03. 16

Figure 3-2. Electron Micrograph and Corresponding EDS Maps of the CCC Version of Glass KT05-05.

Figure 3-3. Electron Micrograph and Corresponding EDS Maps of the CCC Version of Glass KT05-08. 18

Figure 3-4. Backscattered Electron Micrograph of the CCC Version of Glass KT06-04. 20

Figure 3-5. Electron Micrograph and Corresponding EDS Maps of the CCC Version of Glass KT06-07.

Figure 3-6. Electron Micrograph and Corresponding EDS Maps of the CCC Version of Glass KT06-14

Figure 3-7. Scatter Plots of the Major Oxides of the KT06-Series Glasses Prepared to Identify Any Compositional Impacts on Predictability of Chemical Durability.

Figure 3-8. Outcome of the Partitioning Routine for Chemical Composition and Predictability of Chemical Durability for the KT06-Series Glasses.

Figure 3-9. Scatter Plots of the Major Oxides of the KT06-Series Glasses Prepared to Identify Any Compositional Impacts on Predictability of Viscosity. 30

Figure 3-10. Outcome of the Partitioning Routine for Chemical Composition and Predictability of Viscosity for the KT06-Series Glasses. 


\section{LIST OF ABBREVIATIONS}

\begin{tabular}{|c|c|}
\hline $\mathrm{AD}$ & Analytical Development \\
\hline ANOVA & ANalysis Of VAriance \\
\hline ARM & Approved Reference Material \\
\hline $\mathrm{CCC}$ & Canister Centerline Cooled \\
\hline $\mathrm{CST}$ & Crystalline Silicotitanate \\
\hline DWPF & Defense Waste Processing Facility \\
\hline EA & Environmental Assessment \\
\hline EDS & Energy Dispersive Spectroscopy \\
\hline HLW & High Level Waste \\
\hline ICP-AES & Inductively Coupled Plasma - Atomic Emission Spectroscopy \\
\hline LM & Lithium-Metaborate Fusion \\
\hline MAR & Measurement Acceptability Region \\
\hline MST & Monosodium Titanate \\
\hline PCCS & Product Composition Control System \\
\hline PCT & Product Consistency Test \\
\hline $\mathrm{PF}$ & Sodium Peroxide Fusion \\
\hline PSAL & Process Science Analytical Laboratory \\
\hline RMF & Rotary Micro Filtration \\
\hline SCIX & Small Column Ion Exchange \\
\hline SEM & Scanning Electron Microscopy \\
\hline SRR & Savannah River Remediation \\
\hline SRS & Savannah River Site \\
\hline SWPF & Salt Waste Processing Facility \\
\hline $\mathrm{T}_{\mathrm{L}}$ & Liquidus Temperature \\
\hline XRD & X-ray Diffraction \\
\hline
\end{tabular}




\subsection{Introduction}

\subsection{Background}

Savannah River Remediation (SRR) will begin a process referred to as Small Column Ion Exchange (SCIX) to disposition salt solution at the Savannah River Site (SRS) in fiscal year 2014. In the first step of the process, salt solution retrieved from various waste tanks will be struck with Monosodium Titanate (MST) to remove key actinides and strontium. The salt solution will then be processed using Rotary Micro Filtration (RMF) to remove the MST and any insoluble solids. The MST and insoluble solids will accumulate on the bottom of Tank 41. The filtrate from RMF will be fed to ion exchange columns, also in Tank 41 , to remove the ${ }^{137} \mathrm{Cs}$ using Crystalline Silicotitanate (CST) resin. The decontaminated salt solution from SCIX will be sent to the Saltstone Production Facility for immobilization in grout. The ${ }^{137} \mathrm{Cs}-\mathrm{laden}$ CST resin will be sluiced and ground for particle size reduction, then sent to the Defense Waste Processing Facility (DWPF) for immobilization in glass. These processes mirror the current disposition paths for streams associated with the Salt Waste Processing Facility (SWPF), which is under construction.

The MST and insoluble solids from Tank 41 will periodically be transferred to a sludge batch preparation tank (e.g., Tank 42 or Tank 51) as part of the High Level Waste (HLW) sludge batch preparation process for DWPF. The ground, ${ }^{137} \mathrm{Cs}-\mathrm{laden}$ CST material (hereafter referred to simply as CST) from SCIX will be periodically transferred to Tank 40 prior to being processed at DWPF. Periodic additions of CST to Tank 40 would result in a changing composition of each sludge batch as it is processed since Tank 40 serves as the feed tank for the DWPF. Work is currently in progress to determine the feasibility of dropping the ground CST into Tank 41. If ground CST can be dropped into Tank 41 (depending on heat loading issues, among others), the CST would be sent to Tank 42 or Tank 51 using an existing transfer line. Therefore, the studies of SCIX impacts on DWPF glass formulation will encompass scenarios where the CST is sent to either Tank 40 or a sludge batch preparation tank.

This work was initiated by a DWPF Technical Task Request ${ }^{1}$ and was performed following a Task Technical and Quality Assurance Plan. ${ }^{2}$

\subsection{Potential Impacts of SCIX on DWPF Glass Formulation}

The MST and CST from the SCIX process will significantly increase the concentrations of $\mathrm{Nb}_{2} \mathrm{O}_{5}$, $\mathrm{TiO}_{2}$, and $\mathrm{ZrO}_{2}$ in the DWPF feed. Other constituents of MST and CST $-\mathrm{Na}_{2} \mathrm{O}$ and $\mathrm{SiO}_{2}-$ are already present in high concentrations in DWPF glass; thus their influences are well understood. The increased concentrations of $\mathrm{Nb}_{2} \mathrm{O}_{5}, \mathrm{TiO}_{2}$, and $\mathrm{ZrO}_{2}$ will likely have some impact on the properties and performance of the DWPF glass product. Properties such as the liquidus temperature, viscosity, and rate of melting of the glass may be impacted. The performance of the glass, particularly its chemical durability as it pertains to repository acceptance requirements, may also be impacted. The DWPF uses a set of semi-empirical and first-principles models referred to as the Product Composition Control System (PCCS) ${ }^{3}$ to predict the properties and performance of a glass based on its composition since it is not possible or practical to measure these attributes during processing. The objective of this study is to evaluate the impacts of the SCIX streams on the properties and performance of the DWPF glass product and on the applicability of the current process control models.

This report is part of a series of studies on the potential impacts of SCIX on DWPF glass. Fox and Edwards recently performed a paper study evaluation using updated projections for sludge batch compositions and SCIX CST and MST addition rates. ${ }^{4}$ This study found that, as a result of 
the updated composition projections, several viable options were predicted to be available for incorporation of the SCIX streams into either Tank 40 or a sludge batch preparation tank. Transfer of the CST to a sludge batch preparation tank was the preferred option since it allowed more compositional flexibility for frit development while maintaining sufficient projected operating windows. The report again identified several assumptions and limitations associated with the current PCCS models, and recommended that these be further evaluated.

The first report on experimental results in this series covered glass compositions identified as the KT01, KT02, KT03, and KT04-series. ${ }^{5}$ The results presented in that report showed a reasonable ability to incorporate the anticipated SCIX streams into the DWPF-type glass compositions studied, with $\mathrm{TiO}_{2}$ concentrations of $4-5 \mathrm{wt} \%$ in glass. The durability and viscosity models satisfactorily predicted the measured values for the study glasses with the exception of a small number of extreme compositions. It was shown that, based on results for the KT01-series glasses, the liquidus temperature model may need to be adjusted to correctly predict the liquidus temperatures of glasses including the SCIX streams based on the data measured. Liquidus temperature measurements for the KT03 and KT04-series glasses will be documented in a future report.

This report follows with the KT05- and KT06-series glasses. As will be described below, these glasses were selected, fabricated, and characterized to study the potential formation of titaniumcontaining crystalline phases (KT05), and to study a broader range of potential DWPF glass compositions including the SCIX material (KT06).

\subsection{Experimental Procedure}

\subsection{Selection of Glass Compositions}

\subsubsection{KT05-series}

A recent study of high waste loading glasses for enhanced melter throughput identified glass compositions with relatively high $\mathrm{TiO}_{2}$ concentrations (5.7-6.0 wt \%) that formed iron titanate crystalline phases during liquidus temperature determinations. ${ }^{6}$ These compositions are of interest since none of the previous glasses fabricated for the SCIX study have formed crystalline phases containing titanium. ${ }^{5}$ For the current study, the KT05-series glasses, it was hypothesized that an increase in the concentration of $\mathrm{Na}_{2} \mathrm{O}$ in the original compositions could avoid the formation of an iron titanate phase. This hypothesis was based on the results of earlier studies of the KT02-series compositions. ${ }^{5}$ The three glasses that formed iron titanate crystals, labeled FY09EM21-05, -14, and -23 in the previous study, were fabricated again for the current study with the labels KT05-01, -02, and -03 (see Table 2-1). The target compositions of these three glasses were taken from the target values provided in the report, which did not differ significantly from the measured values. ${ }^{6}$ The target $\mathrm{Na}_{2} \mathrm{O}$ concentration for these three compositions was increased to $12 \mathrm{wt} \%$ (glasses KT05-04, -05, and -06) and $14 \mathrm{wt} \%$ (glasses KT05-07, -08, and 09), with the remaining components being normalized to $100 \mathrm{wt} \%$. The resulting compositions are given in Table 2-1. These glasses were fabricated, heat treated, and characterized via X-ray diffraction (XRD) only, since the type of crystallization formed, if any, was the characteristic of interest for these compositions. Chemical composition, durability, viscosity, and liquidus temperature of these glasses were not determined. 
Table 2-1. Target Compositions (wt \%) of the KT05-Series Glasses.

\begin{tabular}{|c|c|c|c|c|c|c|c|c|c|}
\hline Oxide & KT05-01 & KT05-02 & KT05-03 & KT05-04 & KT05-05 & KT05-06 & KT05-07 & KT05-08 & KT05-09 \\
\hline $\mathrm{Al}_{2} \mathrm{O}_{3}$ & 3.60 & 3.25 & 13.96 & 3.52 & 3.18 & 13.65 & 3.44 & 3.11 & 13.34 \\
\hline $\mathrm{B}_{2} \mathrm{O}_{3}$ & 4.50 & 13.65 & 5.78 & 4.40 & 13.34 & 5.65 & 4.30 & 13.04 & 5.52 \\
\hline $\mathrm{BaO}$ & 0.00 & 0.08 & 0.08 & 0.00 & 0.08 & 0.08 & 0.00 & 0.08 & 0.08 \\
\hline $\mathrm{CaO}$ & 4.00 & 0.00 & 0.00 & 3.91 & 0.00 & 0.00 & 3.82 & 0.00 & 0.00 \\
\hline $\mathrm{CdO}$ & 0.00 & 0.30 & 0.30 & 0.00 & 0.29 & 0.29 & 0.00 & 0.28 & 0.28 \\
\hline $\mathrm{Ce}_{2} \mathrm{O}_{3}$ & 0.00 & 0.36 & 0.36 & 0.00 & 0.35 & 0.35 & 0.00 & 0.34 & 0.34 \\
\hline $\mathrm{Cr}_{2} \mathrm{O}_{3}$ & 0.00 & 0.20 & 0.00 & 0.00 & 0.20 & 0.00 & 0.00 & 0.19 & 0.00 \\
\hline $\mathrm{CuO}$ & 0.00 & 0.13 & 0.13 & 0.00 & 0.13 & 0.13 & 0.00 & 0.12 & 0.12 \\
\hline $\mathrm{Fe}_{2} \mathrm{O}_{3}$ & 13.77 & 20.54 & 12.11 & 13.46 & 20.09 & 11.84 & 13.16 & 19.63 & 11.57 \\
\hline $\mathrm{La}_{2} \mathrm{O}_{3}$ & 0.00 & 0.10 & 0.10 & 0.00 & 0.10 & 0.10 & 0.00 & 0.09 & 0.09 \\
\hline $\mathrm{Li}_{2} \mathrm{O}$ & 4.00 & 4.00 & 4.00 & 3.91 & 3.91 & 3.91 & 3.82 & 3.82 & 3.82 \\
\hline $\mathrm{MgO}$ & 0.00 & 0.00 & 1.50 & 0.00 & 0.00 & 1.47 & 0.00 & 0.00 & 1.43 \\
\hline $\mathrm{MnO}$ & 0.30 & 0.30 & 0.30 & 0.29 & 0.29 & 0.29 & 0.29 & 0.29 & 0.29 \\
\hline $\mathrm{Na}_{2} \mathrm{O}$ & 10.00 & 10.00 & 10.00 & 12.00 & 12.00 & 12.00 & 14.00 & 14.00 & 14.00 \\
\hline $\mathrm{NiO}$ & 2.50 & 0.00 & 0.00 & 2.44 & 0.00 & 0.00 & 2.39 & 0.00 & 0.00 \\
\hline $\mathrm{PbO}$ & 0.00 & 0.22 & 0.22 & 0.00 & 0.21 & 0.21 & 0.00 & 0.21 & 0.21 \\
\hline $\mathrm{SiO}_{2}$ & 51.50 & 40.35 & 44.35 & 50.35 & 39.46 & 43.37 & 49.21 & 38.56 & 42.38 \\
\hline $\mathrm{SO}_{4}{ }^{2-}$ & 0.00 & 0.48 & 0.48 & 0.00 & 0.47 & 0.47 & 0.00 & 0.46 & 0.46 \\
\hline $\mathrm{TiO}_{2}$ & 5.83 & 5.71 & 6.00 & 5.70 & 5.58 & 5.87 & 5.57 & 5.45 & 5.73 \\
\hline $\mathrm{ZnO}$ & 0.00 & 0.13 & 0.13 & 0.00 & 0.13 & 0.13 & 0.00 & 0.13 & 0.13 \\
\hline $\mathrm{ZrO}_{2}$ & 0.00 & 0.21 & 0.21 & 0.00 & 0.20 & 0.20 & 0.00 & 0.20 & 0.20 \\
\hline
\end{tabular}




\subsubsection{KT06-series}

Previous glass compositions studied for the SCIX program (the KT01-, KT02-, KT03-, and KT04-series) showed that, in general, the SCIX streams can be incorporated into simulated HLW glass (based on current composition projections) with most properties being predictable using the current DWPF models. Liquidus temperature predictions were the main exception. A different selection strategy was used for the KT06-series glasses with the intent of identifying compositional regions where it becomes difficult to incorporate the SCIX streams in glass, particularly higher $\mathrm{TiO}_{2}$ concentrations. First, the minimum and maximum concentrations of the waste constituents used in the earlier paper study ${ }^{4}$ were identified, as shown in Table 2-2. ${ }^{\text {a }}$ Second, the minor components (i.e., those present in concentrations less than $1 \mathrm{wt} \%$ ) were combined into a single group identified as Others based on their maximum concentrations, as shown in Table 2-3. Third, additional variation was added to expand these intervals as follows:

- Any minimum value that was more than $2 \mathrm{wt} \%$ was decreased by $2 \mathrm{wt} \%$,

- Any maximum value that was greater than $4 \mathrm{wt} \%$ was increased by $2 \mathrm{wt} \%$,

- Any maximum value that was greater than $1 \mathrm{wt} \%$ but less than $4 \mathrm{wt} \%$ was increased by $1 \mathrm{wt} \%$, and

- Any maximum value that was less than $1 \mathrm{wt} \%$ was increased by $0.5 \mathrm{wt} \%$.

The resulting intervals with variation applied are given on the right side of Table 2-2. Note that the $\mathrm{Na}_{2} \mathrm{O}$ concentration was limited to three specific values representing potential washing endpoints for sludge preparation, rather than an interval of potential values. The $\mathrm{TiO}_{2}$ concentration was fixed at $15 \mathrm{wt} \%$ to represent a high loading of CST and MST (relative to the projected values of about $12 \mathrm{wt} \% \mathrm{TiO}_{2}$ ). The $\mathrm{SO}_{4}{ }^{2-}$ concentration was fixed at the current PCCS limit of $0.40 \mathrm{wt} \%$ since no projected value was given at the time of the paper study. ${ }^{4}$

\footnotetext{
${ }^{a}$ Note that the projected values used in this study have been revised slightly from those that appear in the paper study report, although they remain very similar.
} 
Table 2-2. Individual Component Ranges Covering Projections of Sludge Batches 8 through 17, Including SCIX and SWPF Streams.

\begin{tabular}{|c|c|c|c|c|}
\hline \multirow[b]{2}{*}{ Oxide } & \multicolumn{2}{|c|}{ Original Values } & \multicolumn{2}{|c|}{ Values with Variation Applied } \\
\hline & $\begin{array}{c}\text { Minimum } \\
\text { (wt \%) }\end{array}$ & $\begin{array}{c}\text { Maximum } \\
\text { (wt \%) }\end{array}$ & $\begin{array}{c}\text { Minimum } \\
\text { (wt \%) }\end{array}$ & $\begin{array}{c}\text { Maximum } \\
\text { (wt \%) }\end{array}$ \\
\hline $\mathrm{Al}_{2} \mathrm{O}_{3}$ & 10.18 & 21.41 & 8.18 & 23.41 \\
\hline $\mathrm{BaO}$ & 0.17 & 0.23 & \multicolumn{2}{|c|}{ to others } \\
\hline $\mathrm{CaO}$ & 1.76 & 3.31 & 1.76 & 4.31 \\
\hline $\mathrm{Ce}_{2} \mathrm{O}_{3}$ & 0.17 & 0.96 & \multirow{3}{*}{\multicolumn{2}{|c|}{ to others }} \\
\hline $\mathrm{Cr}_{2} \mathrm{O}_{3}$ & 0.22 & 0.46 & & \\
\hline $\mathrm{CuO}$ & 0.09 & 0.13 & & \\
\hline $\mathrm{Fe}_{2} \mathrm{O}_{3}$ & 19.97 & 41.18 & 17.97 & 43.18 \\
\hline $\mathrm{K}_{2} \mathrm{O}$ & 0.09 & 0.37 & \multirow{3}{*}{\multicolumn{2}{|c|}{ to others }} \\
\hline $\mathrm{La}_{2} \mathrm{O}_{3}$ & 0.09 & 0.36 & & \\
\hline $\mathrm{MgO}$ & 0.25 & 0.52 & & \\
\hline $\mathrm{MnO}$ & 0.90 & 6.43 & 0.90 & 8.43 \\
\hline $\mathrm{Na}_{2} \mathrm{O}$ & 20.75 & 28.55 & \multicolumn{2}{|c|}{ fixed at 20,25 , and 30} \\
\hline $\mathrm{Nb}_{2} \mathrm{O}_{5}$ & 0.02 & 3.27 & 0.02 & 4.27 \\
\hline $\mathrm{NiO}$ & 0.29 & 1.95 & 0.29 & 2.95 \\
\hline $\mathrm{PbO}$ & 0.16 & 0.55 & \multicolumn{2}{|c|}{ to others } \\
\hline $\mathrm{SiO}_{2}$ & 0.95 & 9.42 & 0.95 & 11.42 \\
\hline $\mathrm{SO}_{4}{ }^{2-}$ & $\mathrm{n} / \mathrm{a}$ & $\mathrm{n} / \mathrm{a}$ & \multicolumn{2}{|c|}{ fixed at 0.40} \\
\hline $\mathrm{ThO}_{2}$ & 0.00 & 2.91 & 0.00 & 3.91 \\
\hline $\mathrm{TiO}_{2}$ & 0.97 & 11.03 & \multicolumn{2}{|c|}{ fixed at 15.00} \\
\hline $\mathrm{U}_{3} \mathrm{O}_{8}$ & 0.54 & 18.63 & 0.54 & 20.63 \\
\hline $\mathrm{ZnO}$ & 0.00 & 0.26 & \multicolumn{2}{|c|}{ to others } \\
\hline $\mathrm{ZrO}_{2}$ & 0.48 & 2.87 & 0.48 & 3.87 \\
\hline Others & $\mathrm{n} / \mathrm{a}$ & $\mathrm{n} / \mathrm{a}$ & 1.00 & 3.00 \\
\hline
\end{tabular}

Table 2-3. Composition of the Others Category.

\begin{tabular}{||c|c||}
\hline \hline Oxide & wt \% \\
\hline $\mathrm{BaO}$ & 6.07 \\
\hline $\mathrm{Ce}_{2} \mathrm{O}_{3}$ & 25.05 \\
\hline $\mathrm{Cr}_{2} \mathrm{O}_{3}$ & 11.91 \\
\hline $\mathrm{CuO}$ & 3.40 \\
\hline $\mathrm{K}_{2} \mathrm{O}$ & 9.72 \\
\hline $\mathrm{La}_{2} \mathrm{O}_{3}$ & 9.33 \\
\hline $\mathrm{MgO}$ & 13.52 \\
\hline $\mathrm{PbO}$ & 14.28 \\
\hline $\mathrm{ZnO}$ & 6.73 \\
\hline
\end{tabular}

The individual component intervals with variation applied (the right side of Table 2-2) were used to define the outer layer of the sludge composition region from which the KT06-series glass compositions would be developed. Note again that the concentrations of $\mathrm{Na}_{2} \mathrm{O}, \mathrm{SO}_{4}{ }^{2-}$, and $\mathrm{TiO}_{2}$ were fixed at specific values, leaving 11 components with variable concentrations. An inner layer was also defined for the sludge composition region in order to provide more thorough coverage of the potential sludge compositions. The inner layer was created by adding $25 \%$ of each interval to the minimum value of that interval and subtracting $25 \%$ of each interval from the maximum value 
of that interval. The resulting component ranges for the inner layer composition region are also given in Table 2-4.

Table 2-4. Outer and Inner Layer Component Ranges for the KT06-Series Sludge Composition Region.

\begin{tabular}{|c|c|c|c|c|}
\hline \multirow{2}{*}{ Oxide } & \multicolumn{2}{|c|}{ Outer Layer } & \multicolumn{2}{c|}{ Inner Layer } \\
\cline { 2 - 5 } & $\begin{array}{c}\text { Minimum } \\
\text { (wt \%) }\end{array}$ & $\begin{array}{c}\text { Maximum } \\
\text { (wt \%) }\end{array}$ & $\begin{array}{c}\text { Minimum } \\
\text { (wt \%) }\end{array}$ & $\begin{array}{c}\text { Maximum } \\
\text { (wt \%) }\end{array}$ \\
\hline $\mathrm{Al}_{2} \mathrm{O}_{3}$ & 8.18 & 23.41 & 11.98 & 19.60 \\
\hline $\mathrm{CaO}$ & 1.76 & 4.31 & 2.40 & 3.68 \\
\hline $\mathrm{Fe}_{2} \mathrm{O}_{3}$ & 17.97 & 43.18 & 24.27 & 36.88 \\
\hline $\mathrm{MnO}$ & 0.90 & 8.43 & 2.78 & 6.54 \\
\hline $\mathrm{Nb}_{2} \mathrm{O}_{5}$ & 0.02 & 4.27 & 0.95 & 2.28 \\
\hline $\mathrm{NiO}$ & 0.29 & 2.95 & 3.56 & 8.80 \\
\hline $\mathrm{SiO} \mathrm{I}_{2}$ & 0.95 & 11.42 & 0.98 & 2.94 \\
\hline $\mathrm{ThO}_{2}$ & 0.00 & 3.91 & 5.56 & 15.61 \\
\hline $\mathrm{U}_{3} \mathrm{O}_{8}$ & 0.54 & 20.63 & 1.33 & 3.02 \\
\hline $\mathrm{ZrO}_{2}$ & 0.48 & 3.87 & 1.08 & 3.20 \\
\hline $\mathrm{Others}_{2}$ & 1.00 & 3.00 & 1.50 & 2.50 \\
\hline
\end{tabular}

The information of Table 2-4 was used to define the sludge region from which the KT06-series glass compositions were to be selected. Initially, the Design of Experiment platform's Custom Design feature of JMP Version 7.0.2 (SAS Institute, Cary, NC) was used to select 11 sludge compositions satisfying the concentration intervals of Table 2-4, with a provision to incorporate $\mathrm{Na}_{2} \mathrm{O}, \mathrm{SO}_{4}{ }^{2-}$, and $\mathrm{TiO}_{2}$ at the fixed concentrations defined earlier. This JMP feature allows the user to specify the form of a model such as a linear model consisting of a term for each of the 11 oxides of Table 2-4 (including Others). Then the coordinate exchange algorithm in JMP was used to optimally select a specified number of design points, $n$ (where $n \geq 11$ ), for this model from the region defined by the intervals of Table 2-4, with the intervals being specified in JMP during the design activity. The optimality criterion used in this case was D-optimality, which has the goal of minimizing $\left|\left(X^{T} X\right)^{-1}\right|$, where $X$ is the design matrix, $X^{T}$ indicates the transpose of $X$, $\left(X^{T} X\right)^{-1}$ indicates the matrix inversion of the product of $X^{T}$ and $X$, and $\left|\left(X^{T} X\right)^{-1}\right|$ represents the determinant of the matrix $\left(X^{T} X\right)^{-1}$. In the task, the number of design points, $n$, was taken to be its smallest possible value, 11. This procedure was performed several times: once for the outer layer region defined by Table 2-4 at each $\mathrm{Na}_{2} \mathrm{O}$ concentration of 20, 25, and $30 \mathrm{wt} \%$, and once for the inner layer region defined by Table 2-4 at $\mathrm{Na}_{2} \mathrm{O}$ concentrations of 20 and $25 \mathrm{wt} \%$. The centroids, or averages, of each set of optimal sludge compositions were also defined, for a total of 60 sludge compositions.

Each of the 60 sludge compositions was combined with an array of 1,144 potential frit compositions, as defined by the ranges of frit oxides given in Table $2-5 \mathrm{in} 1 \mathrm{wt} \%$ increments, over a series of waste loadings from 30 to $60 \%$. The resulting glass compositions $(2,127,840$ frit and sludge combinations) were evaluated using the PCCS Measurement Acceptability Region (MAR) to identify glasses that were predicted to be acceptable for processing at the DWPF. The PCCS constraint for $\mathrm{TiO}_{2}$ concentration was ignored for the purposes of this study. The results were reviewed and only frit and sludge combinations that provided acceptable glasses over a range of waste loadings of at least $35-45 \%$ were allowed to continue in the selection process. 


\section{Table 2-5. Array of Candidate Frit Compositions} Used in Selecting the KT06-Series Glasses.

\begin{tabular}{||c|c|}
\hline Oxide & wt \% \\
\hline $\mathrm{B}_{2} \mathrm{O}_{3}$ & $8-20$ \\
\hline $\mathrm{Li}_{2} \mathrm{O}$ & $5-12$ \\
\hline $\mathrm{Na}_{2} \mathrm{O}$ & $0-10$ \\
\hline $\mathrm{SiO}_{2}$ & $58-87$ \\
\hline
\end{tabular}

In order to further reduce the number of glass compositions to a reasonable quantity for fabrication and characterization, the acceptable frit and sludge compositions were reviewed to identify those sludge compositions that provided broad coverage of $\mathrm{Al}_{2} \mathrm{O}_{3}$ and $\mathrm{Fe}_{2} \mathrm{O}_{3}$ concentrations, as these components are major constituents of the sludge. The sludges were grouped by their $\mathrm{Na}_{2} \mathrm{O}$ concentrations $(20,25$, and $30 \mathrm{wt} \%)$ and screened for those that provided the largest variation in $\mathrm{Al}_{2} \mathrm{O}_{3}: \mathrm{Fe}_{2} \mathrm{O}_{3}$ ratios. The results are shown in Figure 2-1, where the diagonal and corner points of the $\mathrm{Al}_{2} \mathrm{O}_{3}: \mathrm{Fe}_{2} \mathrm{O}_{3}$ ratios have been identified. This process resulted in the identification of four sludge compositions at $20 \mathrm{wt} \% \mathrm{Na}_{2} \mathrm{O}$, three sludge compositions at $25 \mathrm{wt} \% \mathrm{Na}_{2} \mathrm{O}$, and two sludge compositions at $30 \mathrm{wt} \% \mathrm{Na}_{2} \mathrm{O}$. Note that two of the sludge compositions at $20 \mathrm{wt} \% \mathrm{Na}_{2} \mathrm{O}$ have the same $\mathrm{Al}_{2} \mathrm{O}_{3}$ and $\mathrm{Fe}_{2} \mathrm{O}_{3}$ concentrations but differ in their values for some of the other components; therefore, only three points are shown on the plot in Figure 2-1a. 


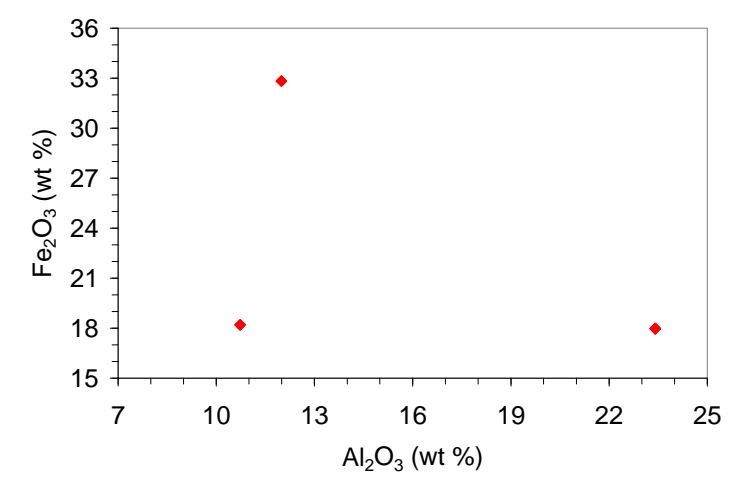

(a)

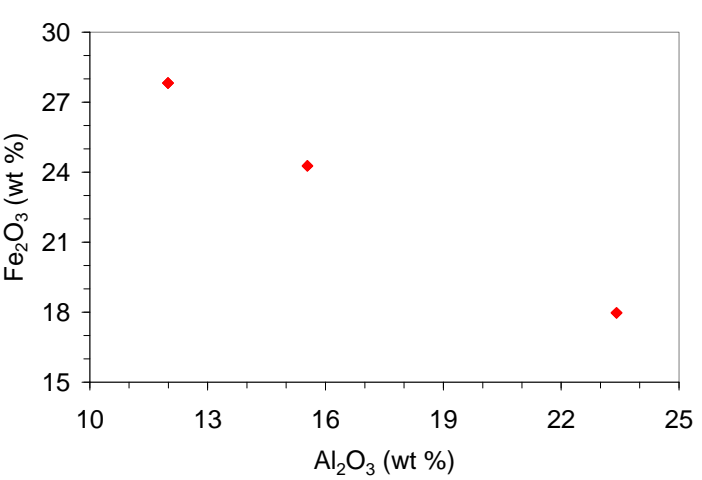

(b)

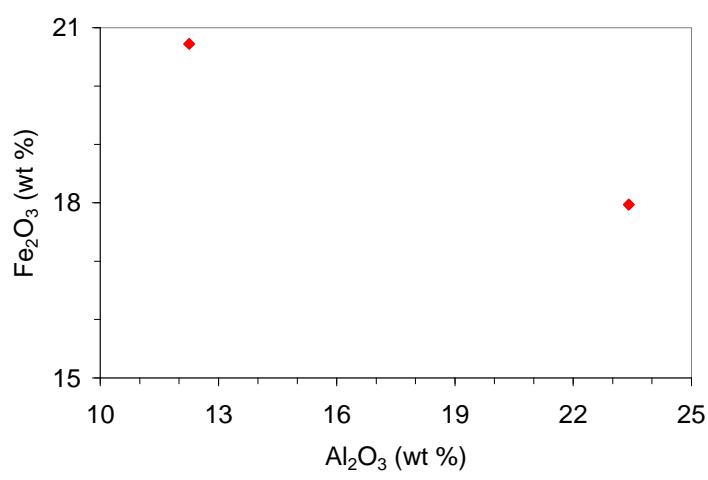

(c)

Figure 2-1. Graphical Representation of the $\mathrm{Al}_{2} \mathrm{O}_{3}: \mathrm{Fe}_{2} \mathrm{O}_{3}$ Ratios of the Sludge Compositions Selected for the KT06-Series Glasses. The Plots Correspond to Sludge $\mathrm{Na}_{2} \mathrm{O}$ Concentrations of 20 wt \% (a), 25 wt \% (b), and 30 wt \% (c).

Next, frit compositions producing PCCS MAR acceptable glasses with these sludges at $40 \%$ waste loading were down-selected. The $\mathrm{Na}_{2} \mathrm{O}$ in the frits was fixed at $2 \mathrm{wt} \%$ since the sludges provide three different $\mathrm{Na}_{2} \mathrm{O}$ concentrations. The $\mathrm{B}_{2} \mathrm{O}_{3}$ concentration in the frits was fixed at either 8 or $14 \mathrm{wt} \%$ to provide the opportunity to study any potential impact of this component on the properties and performance of the glasses. The $\mathrm{Li}_{2} \mathrm{O}$ concentrations in the frits were kept as similar as possible, although some variation was necessary in order to maintain PCCS MAR acceptability while meeting the other conditions described above. Six frit compositions were needed to meet these criteria for the sludge compositions selected, and the compositions of these frits are given in Table 2-6. ${ }^{\text {a }}$ The outcome of the selection process was 18 glass compositions for the KT06-series, as described in Table 2-7. The compositions of these glasses were normalized to $100 \mathrm{wt} \%$ without their $\mathrm{U}_{3} \mathrm{O}_{8}$ and $\mathrm{ThO}_{2}$ components to facilitate fabrication and testing in a non-radiological laboratory. The normalized compositions were again evaluated using the PCCS MAR, which confirmed that the compositions were acceptable with the exception of the $\mathrm{TiO}_{2}$ constraint. The target compositions of each of the KT06-series glasses are given in detail in Table 2-8.

\footnotetext{
${ }^{a}$ Note that these frit compositions and their identifiers were developed solely for this research and development work, and they do not represent candidate frits for actual processing at the DWPF.
} 
Table 2-6. Frit Compositions Selected for the KT06-Series Glasses.

\begin{tabular}{||c|c|c|c|c||}
\hline Frit ID & $\begin{array}{c}\mathbf{B}_{2} \mathbf{O}_{\mathbf{3}} \\
\text { (wt \%) }\end{array}$ & $\begin{array}{c}\mathbf{L i}_{2} \mathbf{O} \\
\text { (wt \%) }\end{array}$ & $\begin{array}{c}\mathbf{N a}_{2} \mathbf{O} \\
\text { (wt \%) }\end{array}$ & $\begin{array}{c}\mathbf{S i O}_{2} \\
\text { (wt \%) }\end{array}$ \\
\hline $\mathrm{KS}-100$ & 14 & 6 & 2 & 78 \\
\hline $\mathrm{KS}-101$ & 14 & 7 & 2 & 77 \\
\hline $\mathrm{KS}-102$ & 14 & 9 & 2 & 75 \\
\hline $\mathrm{KS}-103$ & 8 & 11 & 2 & 79 \\
\hline $\mathrm{KS}-104$ & 8 & 8 & 2 & 82 \\
\hline $\mathrm{KS}-105$ & 8 & 9 & 2 & 81 \\
\hline
\end{tabular}

Table 2-7. Description of Glasses Selected for the KT06-Series.

\begin{tabular}{|c|c|c|c|c|c|c|c|}
\hline Glass ID & $\begin{array}{l}\text { WL } \\
(\%)\end{array}$ & Sludge ID & $\begin{array}{c}\text { Sludge } \\
\mathrm{Al}_{2} \mathrm{O}_{3} \\
\text { (wt \%) }\end{array}$ & $\begin{array}{c}\text { Sludge } \\
\mathrm{Fe}_{2} \mathrm{O}_{3} \\
\text { (wt \%) }\end{array}$ & $\begin{array}{c}\text { Sludge } \\
\mathrm{Na}_{2} \mathrm{O} \\
\text { (wt \%) }\end{array}$ & Frit ID & $\begin{array}{c}\text { Frit } \mathrm{B}_{2} \mathrm{O}_{3} \\
\text { (wt \%) }\end{array}$ \\
\hline KT06-01 & 40 & Outer Layer Centroid & 12.25 & 20.72 & 30 & KS-100 & 14 \\
\hline KT06-02 & 40 & Outer Layer 8 & 23.41 & 17.97 & 30 & KS-100 & 14 \\
\hline KT06-03 & 40 & Outer Layer Centroid & 12.25 & 20.72 & 30 & KS-104 & 8 \\
\hline KT06-04 & 40 & Outer Layer 8 & 23.41 & 17.97 & 30 & KS-104 & 8 \\
\hline KT06-05 & 40 & Inner Layer 2 & 15.54 & 24.27 & 25 & KS-101 & 14 \\
\hline KT06-06 & 40 & Inner Layer 6 & 11.99 & 27.83 & 25 & KS-101 & 14 \\
\hline KT06-07 & 40 & Outer Layer 6 & 23.41 & 17.97 & 25 & KS-101 & 14 \\
\hline KT06-08 & 40 & Inner Layer 2 & 15.54 & 24.27 & 25 & KS-105 & 8 \\
\hline KT06-09 & 40 & Inner Layer 6 & 11.99 & 27.83 & 25 & KS-105 & 8 \\
\hline KT06-10 & 40 & Outer Layer 6 & 23.41 & 17.97 & 25 & KS-105 & 8 \\
\hline KT06-11 & 40 & Inner Layer 11 & 11.99 & 32.83 & 20 & KS-101 & 14 \\
\hline KT06-12 & 40 & Outer Layer 7 & 10.73 & 18.20 & 20 & KS-102 & 14 \\
\hline KT06-13 & 40 & Outer Layer 9 & 23.41 & 17.97 & 20 & KS-102 & 14 \\
\hline KT06-14 & 40 & Outer Layer 10 & 23.41 & 17.97 & 20 & KS-102 & 14 \\
\hline KT06-15 & 40 & Outer Layer 7 & 10.73 & 18.20 & 20 & KS-103 & 8 \\
\hline KT06-16 & 40 & Outer Layer 9 & 23.41 & 17.97 & 20 & KS-103 & 8 \\
\hline KT06-17 & 40 & Outer Layer 10 & 23.41 & 17.97 & 20 & KS-103 & 8 \\
\hline KT06-18 & 40 & Inner Layer 11 & 11.99 & 32.83 & 20 & KS-104 & 8 \\
\hline
\end{tabular}


Table 2-8. Target Compositions (wt \%) of the KT06-Series Glasses.

\begin{tabular}{|c|c|c|c|c|c|c|c|c|c|}
\hline Oxide & KT06-01 & КT06-02 & KT06-03 & KT06-04 & KT06-05 & KT06-06 & КT06-07 & KT06-08 & KT06-09 \\
\hline $\mathrm{Al}_{2} \mathrm{O}_{3}$ & 5.45 & 9.46 & 5.45 & 9.46 & 6.98 & 5.38 & 9.45 & 6.98 & 5.38 \\
\hline $\mathrm{B}_{2} \mathrm{O}_{3}$ & 8.40 & 8.40 & 4.80 & 4.80 & 8.40 & 8.40 & 8.40 & 4.80 & 4.80 \\
\hline $\mathrm{BaO}$ & 0.05 & 0.02 & 0.05 & 0.02 & 0.03 & 0.03 & 0.05 & 0.03 & 0.03 \\
\hline $\mathrm{CaO}$ & 1.20 & 1.74 & 1.20 & 1.74 & 1.08 & 1.08 & 0.71 & 1.08 & 1.08 \\
\hline $\mathrm{Ce}_{2} \mathrm{O}_{3}$ & 0.21 & 0.10 & 0.21 & 0.10 & 0.11 & 0.11 & 0.22 & 0.11 & 0.11 \\
\hline $\mathrm{Cr}_{2} \mathrm{O}_{3}$ & 0.10 & 0.05 & 0.10 & 0.05 & 0.05 & 0.05 & 0.10 & 0.05 & 0.05 \\
\hline $\mathrm{CuO}$ & 0.03 & 0.01 & 0.03 & 0.01 & 0.02 & 0.02 & 0.03 & 0.02 & 0.02 \\
\hline $\mathrm{Fe}_{2} \mathrm{O}_{3}$ & 9.22 & 7.26 & 9.22 & 7.26 & 10.90 & 12.49 & 7.25 & 10.90 & 12.49 \\
\hline $\mathrm{K}_{2} \mathrm{O}$ & 0.08 & 0.04 & 0.08 & 0.04 & 0.04 & 0.04 & 0.09 & 0.04 & 0.04 \\
\hline $\mathrm{La}_{2} \mathrm{O}_{3}$ & 0.08 & 0.04 & 0.08 & 0.04 & 0.04 & 0.04 & 0.08 & 0.04 & 0.04 \\
\hline $\mathrm{Li}_{2} \mathrm{O}$ & 3.60 & 3.60 & 4.80 & 4.80 & 4.20 & 4.20 & 4.20 & 5.40 & 5.40 \\
\hline $\mathrm{MgO}$ & 0.11 & 0.05 & 0.11 & 0.05 & 0.06 & 0.06 & 0.12 & 0.06 & 0.06 \\
\hline $\mathrm{MnO}$ & 1.38 & 1.13 & 1.38 & 1.13 & 1.25 & 1.25 & 3.40 & 1.25 & 1.25 \\
\hline $\mathrm{Na}_{2} \mathrm{O}$ & 13.20 & 13.20 & 13.20 & 13.20 & 11.20 & 11.20 & 11.20 & 11.20 & 11.20 \\
\hline $\mathrm{Nb}_{2} \mathrm{O}_{5}$ & 0.63 & 0.08 & 0.63 & 0.08 & 0.55 & 0.55 & 0.08 & 0.55 & 0.55 \\
\hline $\mathrm{NiO}$ & 0.63 & 1.19 & 0.63 & 1.19 & 0.43 & 0.43 & 0.12 & 0.43 & 0.43 \\
\hline $\mathrm{PbO}$ & 0.12 & 0.06 & 0.12 & 0.06 & 0.06 & 0.06 & 0.13 & 0.06 & 0.06 \\
\hline $\mathrm{SO}_{4}{ }^{2-}$ & 0.18 & 0.16 & 0.18 & 0.16 & 0.18 & 0.18 & 0.16 & 0.18 & 0.18 \\
\hline $\mathrm{SiO}_{2}$ & 48.49 & 47.18 & 50.89 & 49.58 & 47.80 & 47.80 & 46.58 & 50.20 & 50.20 \\
\hline $\mathrm{TiO}_{2}$ & 6.00 & 6.00 & 6.00 & 6.00 & 6.00 & 6.00 & 6.00 & 6.00 & 6.00 \\
\hline $\mathrm{ZnO}$ & 0.06 & 0.03 & 0.06 & 0.03 & 0.03 & 0.03 & 0.06 & 0.03 & 0.03 \\
\hline $\mathrm{ZrO}_{2}$ & 0.76 & 0.19 & 0.76 & 0.19 & 0.60 & 0.60 & 1.56 & 0.60 & 0.60 \\
\hline
\end{tabular}


Table 2-8. Target Compositions (wt \%) of the KT06-Series Glasses. (continued)

\begin{tabular}{|c|c|c|c|c|c|c|c|c|c|}
\hline Oxide & KT06-10 & KT06-11 & KT06-12 & KT06-13 & KT06-14 & KT06-15 & KT06-16 & KT06-17 & KT06-18 \\
\hline $\mathrm{Al}_{2} \mathrm{O}_{3}$ & 9.45 & 5.33 & 6.29 & 9.44 & 11.42 & 6.29 & 9.44 & 11.42 & 5.33 \\
\hline $\mathrm{B}_{2} \mathrm{O}_{3}$ & 4.80 & 8.40 & 8.40 & 8.40 & 8.40 & 4.80 & 4.80 & 4.80 & 4.80 \\
\hline $\mathrm{BaO}$ & 0.05 & 0.03 & 0.11 & 0.07 & 0.03 & 0.11 & 0.07 & 0.03 & 0.03 \\
\hline $\mathrm{CaO}$ & 0.71 & 1.07 & 1.03 & 0.71 & 2.10 & 1.03 & 0.71 & 2.10 & 1.07 \\
\hline $\mathrm{Ce}_{2} \mathrm{O}_{3}$ & 0.22 & 0.11 & 0.44 & 0.30 & 0.12 & 0.44 & 0.30 & 0.12 & 0.11 \\
\hline $\mathrm{Cr}_{2} \mathrm{O}_{3}$ & 0.10 & 0.05 & 0.21 & 0.14 & 0.06 & 0.21 & 0.14 & 0.06 & 0.05 \\
\hline $\mathrm{K}_{2} \mathrm{O}$ & 0.09 & 0.04 & 0.17 & 0.12 & 0.05 & 0.17 & 0.12 & 0.05 & 0.04 \\
\hline $\mathrm{La}_{2} \mathrm{O}_{3}$ & 0.08 & 0.04 & 0.16 & 0.11 & 0.05 & 0.16 & 0.11 & 0.05 & 0.04 \\
\hline $\mathrm{Li}_{2} \mathrm{O}$ & 5.40 & 4.20 & 5.40 & 5.40 & 5.40 & 6.60 & 6.60 & 6.60 & 4.80 \\
\hline $\mathrm{MgO}$ & 0.12 & 0.06 & 0.24 & 0.16 & 0.07 & 0.24 & 0.16 & 0.07 & 0.06 \\
\hline $\mathrm{MnO}$ & 3.40 & 1.24 & 0.53 & 3.40 & 0.44 & 0.53 & 3.40 & 0.44 & 1.24 \\
\hline $\mathrm{SO}_{4}{ }^{2-}$ & 0.16 & 0.18 & 0.23 & 0.16 & 0.20 & 0.23 & 0.16 & 0.20 & 0.18 \\
\hline $\mathrm{SiO}_{2}$ & 48.98 & 47.79 & 45.56 & 48.44 & 45.46 & 47.96 & 50.84 & 47.86 & 50.79 \\
\hline $\mathrm{TiO}_{2}$ & 6.00 & 6.00 & 6.00 & 6.00 & 6.00 & 6.00 & 6.00 & 6.00 & 6.00 \\
\hline $\mathrm{ZnO}$ & 0.06 & 0.03 & 0.12 & 0.08 & 0.03 & 0.12 & 0.08 & 0.03 & 0.03 \\
\hline $\mathrm{ZrO}_{2}$ & 1.56 & 0.59 & 2.27 & 0.19 & 1.89 & 2.27 & 0.19 & 1.89 & 0.59 \\
\hline
\end{tabular}




\subsection{Glass Fabrication}

Each of the study glasses was prepared from the proper proportions of reagent-grade metal oxides, carbonates, and boric acid in $200 \mathrm{~g}$ batches. The raw materials were thoroughly mixed and placed into platinum/gold, $250 \mathrm{ml}$ crucibles. The batch was placed into a high-temperature furnace at the melt temperature of $1150{ }^{\circ} \mathrm{C}$. The crucible was removed from the furnace after an isothermal hold for 1 hour. The glass was poured onto a clean, stainless steel plate and allowed to air cool (quench). The glass pour patty was used as a sampling stock for the various property measurements described below.

Glasses KT05-02, -03 , and -04 were ground and melted a second time due to unincorporated batch material remaining in the crucibles after the first melt.

Approximately $25 \mathrm{~g}$ of each glass was heat-treated to simulate cooling along the centerline of a DWPF-type canister ${ }^{7}$ to gauge the effects of thermal history on the product performance. This cooling schedule is referred to as the CCC heat treatment. Visual observations of both quenched and CCC glasses were documented.

\subsection{Composition Analysis}

To confirm that the as-fabricated glasses met the target compositions, a representative sample from each quenched glass in the KT06-series was submitted to the Process Science Analytical Laboratory (PSAL) for chemical analysis under the auspices of an analytical plan. ${ }^{8}$ Once again, the KT05-series glasses were not measured. Two dissolution techniques, sodium peroxide fusion (PF) and lithium-metaborate (LM), were used to prepare the glass samples, in duplicate, for analysis. Each of the samples was analyzed, twice for each element of interest, by Inductively Coupled Plasma - Atomic Emission Spectroscopy (ICP-AES). Glass standards (Batch 1) were also intermittently measured to assess the performance of the ICP-AES instrument over the course of these analyses.

\subsection{X-Ray Diffraction Analysis}

Representative samples of each quenched and CCC glass were submitted to Analytical Development (AD) for XRD analysis. Samples were run under conditions providing a detection limit of approximately $0.5 \mathrm{vol} \%$. That is, if crystals (or unincorporated batch material) were present at $0.5 \mathrm{vol} \%$ or greater, the diffractometer would not only be capable of detecting the crystals but would also allow a qualitative determination of the type of crystal(s) present. Otherwise, a characteristically high background signal (amorphous hump) devoid of crystalline peaks indicates that the glass is free of crystallization, suggesting either a completely amorphous product or that the degree of crystallization is below the detection limit.

\subsection{Scanning Electron Microscopy and Energy Dispersive Spectroscopy}

Scanning Electron Microscopy (SEM) and Energy Dispersive Spectroscopy (EDS) were used to provide qualitative information on the types of crystallization present in select glasses in the KT05- and KT06-series. Samples of crushed glass were prepared by adhering particles to carbon tape on aluminum specimen holders. The samples were viewed both with and without a conductive carbon coating, depending on the instrument used.

\subsection{Product Consistency Test}

The Product Consistency Test (PCT) Method- $\mathrm{A}^{9}$ was performed in triplicate on each KT06-series quenched and CCC glass to assess chemical durability. The PCT responses for the KT05-series glasses were not measured. Also included in the experimental test matrix was the Environmental 
Assessment (EA) benchmark glass, ${ }^{10}$ the Approved Reference Material (ARM) glass, ${ }^{11}$ and blanks from the sample cleaning batch. Samples were ground, washed, and prepared according to the standard procedure. ${ }^{9}$ Fifteen milliliters of Type-I ASTM water were added to $1.5 \mathrm{~g}$ of glass in stainless steel vessels. The vessels were closed, sealed, and placed in an oven at $90 \pm 2{ }^{\circ} \mathrm{C}$ where the samples were maintained at temperature for 7 days. Once cooled, the resulting solutions were sampled (filtered and acidified), then labeled and analyzed by PSAL under the auspices of an analytical plan. ${ }^{12}$ Samples of a multi-element, standard solution were also included in the analytical plan as a check on the accuracy of the ICP-AES instrument used for these measurements. Normalized release rates were calculated based on the target and measured compositions using the average of the common logarithms of the leachate concentrations.

\section{$2.7 \underline{\text { Viscosity }}$}

The viscosities of the KT06-series glasses were measured following Procedure A of the ASTM C 965 standard. ${ }^{13}$ The viscosities of the KT05-series glasses were not measured. An Orton high temperature rotating spindle viscometer was used with platinum crucibles and spindles. The crucible and spindle were specially designed to operate with small quantities of glass to support measurements of radioactive glasses when necessary. ${ }^{14,15}$ A well characterized standard glass was used to determine the appropriate spindle constants. ${ }^{15,16}$ Measurements were taken over a range of temperatures from 1050 to $1250^{\circ} \mathrm{C}$ in $50^{\circ} \mathrm{C}$ intervals. Measurements at $1150{ }^{\circ} \mathrm{C}$ were taken at three different times during the procedure to provide an opportunity to identify the effects of any crystallization or volatilization that may have occurred during the test. The data were fit to a Fulcher equation ${ }^{17,18}$ to provide a measured viscosity value at the nominal DWPF melt temperature of $1150^{\circ} \mathrm{C}$.

\subsection{Liquidus Temperature}

Measurements of the liquidus temperatures $\left(\mathrm{T}_{\mathrm{L}}\right)$ of the KT06-series glasses are underway at the time of this report. The data will be reported separately, along with $\mathrm{T}_{\mathrm{L}}$ data for the KT03 and KT04-series glasses. ${ }^{\mathrm{a}}$

\subsection{Results and Discussion}

\subsection{Homogeneity}

The homogeneity of each glass sample was assessed via XRD and visual observations. The results will be discussed below for each series of glasses. The potential impacts of any crystallization that was identified will be discussed during the later description of the measured properties of the glasses (i.e., durability, viscosity, etc.).

\subsubsection{KT05-Series}

Visual observations of the quenched versions of the KT05-series glasses identified no visible crystallization for most of the compositions. ${ }^{b}$ Composition KT05-02 had some minor crystallization visible on the surface of the quenched glass. Compositions KT05-03 and -06 had visible crystallization throughout the quenched glass. The XRD results agreed with these observations in that most of the glasses were XRD amorphous. Composition KT05-02 was XRD amorphous, indicating that the volume of the visible surface crystallization was very small. Composition KT05-03 contained iron titanium oxide $\left(\mathrm{Fe}_{3} \mathrm{Ti}_{3} \mathrm{O}_{10}\right)$ and a second crystalline phase

\footnotetext{
${ }^{a}$ SRNL-STI-2010-00703, "Impacts of Small Column Ion Exchange Streams on DWPF Glass Formulation: KT03, KT04, and KT06-Series Liquidus Temperature Measurements," in draft.

${ }^{\mathrm{b}}$ See laboratory notebook SRNL-NB-2010-00027 for a complete record of the visual observations and XRD data.
} 
that could not be identified using the crystallographic database. Composition KT05-06 contained a different form of iron titanium oxide, best matched by the stoichiometry $\mathrm{Fe}_{9} \mathrm{TiO}_{15}$.

Visual observations of the CCC versions of the KT05-series glasses identified surface and bulk crystallization for all of the compositions. The XRD results for the $\mathrm{CCC}$ versions of these glasses are given in Table 3-1. Note that it was not possible to distinguish between the diffraction patterns for Hematite $\left(\mathrm{Fe}_{2} \mathrm{O}_{3}\right)$ and a form of iron titanium oxide, $\mathrm{Fe}_{9} \mathrm{TiO}_{15}$, which was identified in some of the glasses. SEM and EDS were used to further characterize these phases.

Table 3-1. XRD Results for the KT05-Series Glasses.

\begin{tabular}{|c|c|c|}
\hline Glass ID & $\begin{array}{c}\text { Heat } \\
\text { Treatment }\end{array}$ & XRD Results \\
\hline \multirow{2}{*}{ KT05-01 } & Quenched & Amorphous \\
\hline & $\mathrm{CCC}$ & Aegirine $\left(\mathrm{NaFe}^{+3}\left(\mathrm{SiO}_{3}\right)_{2}\right)$, Trevorite $\left(\mathrm{NiFe}_{2} \mathrm{O}_{4}\right)$, unidentified phase \\
\hline \multirow{2}{*}{ KT05-02 } & Quenched & Amorphous \\
\hline & $\mathrm{CCC}$ & Hematite $\left(\mathrm{Fe}_{2} \mathrm{O}_{3}\right)$-or- $\mathrm{Fe}_{9} \mathrm{TiO}_{15}$, and unidentified phase \\
\hline \multirow{2}{*}{ KT05-03 } & Quenched & $\mathrm{Fe}_{2} \mathrm{Ti}_{3} \mathrm{O}_{10}$ and unidentified phase \\
\hline & $\mathrm{CCC}$ & $\mathrm{Fe}_{3} \mathrm{Ti}_{3} \mathrm{O}_{10}$ \\
\hline \multirow{2}{*}{ KT05-04 } & Quenched & Amorphous \\
\hline & $\mathrm{CCC}$ & Aegirine $\left(\mathrm{NaFe}^{+3}\left(\mathrm{SiO}_{3}\right)_{2}\right)$ \\
\hline \multirow{2}{*}{ KT05-05 } & Quenched & Amorphous \\
\hline & $\mathrm{CCC}$ & Hematite $\left(\mathrm{Fe}_{2} \mathrm{O}_{3}\right)$-or- $\mathrm{Fe}_{9} \mathrm{TiO}_{15}$ \\
\hline \multirow[b]{2}{*}{ KT05-06 } & Quenched & Hematite $\left(\mathrm{Fe}_{2} \mathrm{O}_{3}\right)$-or- $\mathrm{Fe}_{9} \mathrm{TiO}_{15}$ \\
\hline & $\mathrm{CCC}$ & $\begin{array}{l}\text { Pseudobrookite }\left(\mathrm{Fe}_{2} \mathrm{TiO}_{5}\right) \text {, Hematite }\left(\mathrm{Fe}_{2} \mathrm{O}_{3}\right) \text {-or- } \mathrm{Fe}_{9} \mathrm{TiO}_{15} \text {, } \\
\text { Nepheline }\left(\mathrm{NaAlSiO}_{4}\right)\end{array}$ \\
\hline \multirow{2}{*}{ КT05-07 } & Quenched & Amorphous \\
\hline & $\mathrm{CCC}$ & $\mathrm{LiFeO}_{2}$ \\
\hline \multirow{2}{*}{ KT05-08 } & Quenched & Amorphous \\
\hline & $\mathrm{CCC}$ & Hematite $\left(\mathrm{Fe}_{2} \mathrm{O}_{3}\right)$-or- $\mathrm{Fe}_{9} \mathrm{TiO}_{15}$ \\
\hline \multirow{2}{*}{ KT05-09 } & Quenched & Amorphous \\
\hline & $\mathrm{CCC}$ & $\mathrm{LiFeTiO}_{4}$, Nepheline $\left(\mathrm{NaAlSiO}_{4}\right)$ and $\mathrm{Fe}_{9} \mathrm{TiO}_{15}$ \\
\hline
\end{tabular}

In general, the glasses based on composition FY09EM21-05 (KT05-01, -04, and -07; see Section 2.1.1) had no Ti-containing crystalline phases, regardless of heat treatment or $\mathrm{Na}_{2} \mathrm{O}$ concentration. The glasses based on composition FY09EM21-14 (KT-02, -05, and -08) formed a Ti-containing crystalline phase after the CCC heat treatment (as will be confirmed via SEM and EDS), regardless of $\mathrm{Na}_{2} \mathrm{O}$ concentration. For the glasses based on composition FY09EM21-23 (KT05-03, -06, and -09), increasing $\mathrm{Na}_{2} \mathrm{O}$ concentrations did appear to reduce the propensity for the formation of a Ti-containing crystalline phase, for both the quenched and the CCC versions of the glasses. However, due to the higher $\mathrm{Al}_{2} \mathrm{O}_{3}$ concentration of composition FY09EM21-23, the addition of larger concentrations of $\mathrm{Na}_{2} \mathrm{O}$ results in the formation of nepheline in the CCC versions of glasses KT05-06 and -09, which can adversely impact chemical durability.

SEM/EDS analysis of select KT05-series glasses confirmed the presence of multiple Ticontaining crystalline phases. Glass KT05-03 was found to contain $\mathrm{Fe}_{2} \mathrm{Ti}_{3} \mathrm{O}_{10}$ and an unidentified phase by XRD (Table 3-1). SEM/EDS analysis showed that the unidentified phase was likely another iron titanium oxide with a different stoichiometry. Figure 3-1 shows the results of $\mathrm{SEM} / \mathrm{EDS}$ analysis of one area of this glass. The amorphous region, Spot 1, contains mostly $\mathrm{Si}$ along with several other elements. The larger crystals at Spot 2 contain a high concentration of $\mathrm{Ti}$ 
relative to $\mathrm{Fe}$, while the smaller crystals at Spot 3 contain a high concentration of Fe relative to Ti. This indicates that two different stoichiometries of iron titanium oxide are present in this glass.

SEM/EDS elemental mapping was used to determine whether the CCC version of glass KT05-05 contained an iron titanium oxide or simply hematite. The EDS map for Ti in Figure 3-2 indicates a higher concentration of $\mathrm{Ti}$ in the crystalline phases relative to the surrounding amorphous glass. In particular, the small crystal near the center of the micrograph appears to contain a higher concentration of $\mathrm{Ti}$ relative to the larger crystals at the bottom of the micrograph, which may indicate two different stoichiometries. Overall, these data confirm the presence of a Ticontaining crystalline phase in glass KT05-05. A similar result was found for the CCC version of glass KT05-08 (Figure 3-3), where the crystalline phase contains both Fe and Ti. 


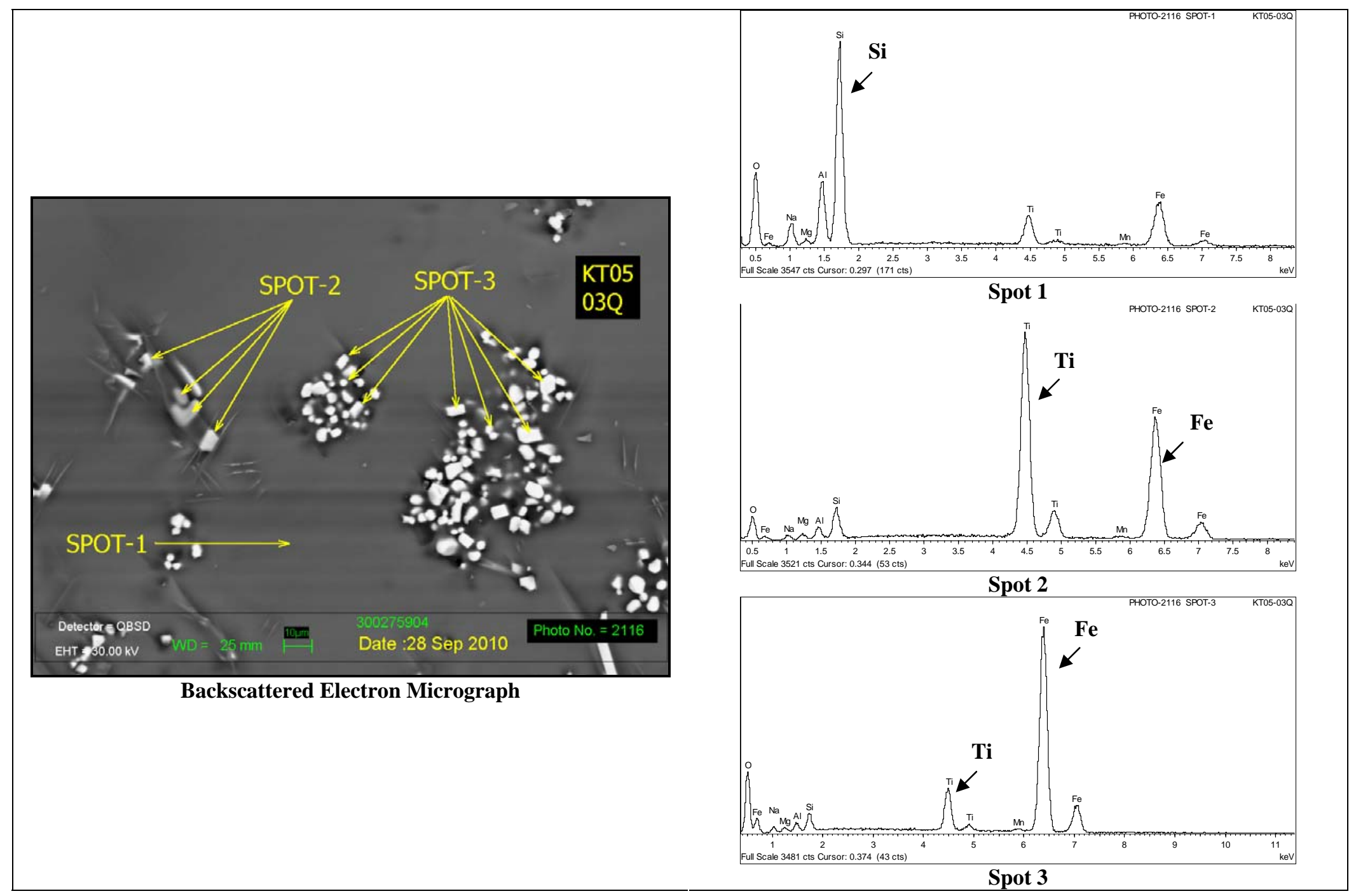

Figure 3-1. Electron Micrograph and Corresponding EDS Spectra of the Quenched Version of Glass KT05-03. 

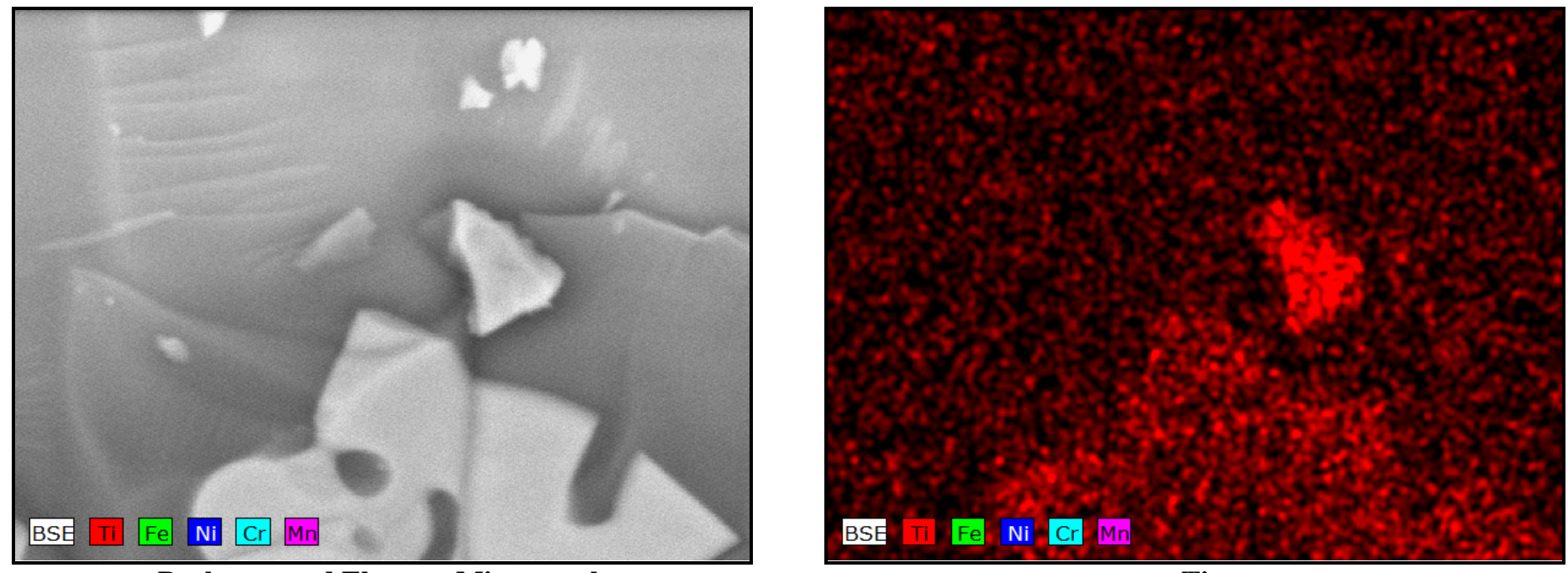

Backscattered Electron Micrograph

$\mathrm{Ti}$

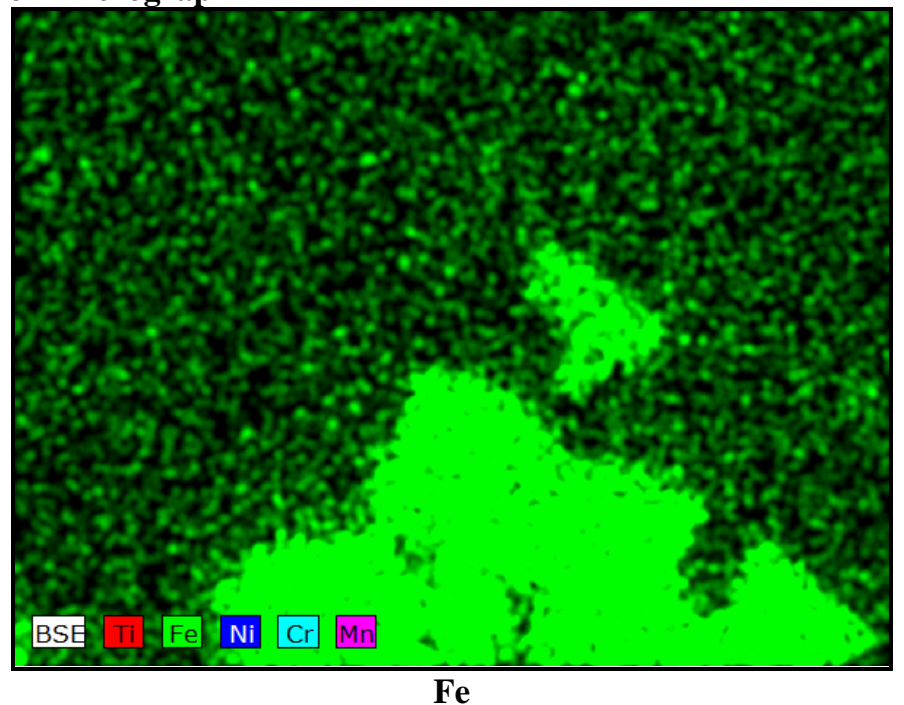

Figure 3-2. Electron Micrograph and Corresponding EDS Maps of the CCC Version of Glass KT05-05. 


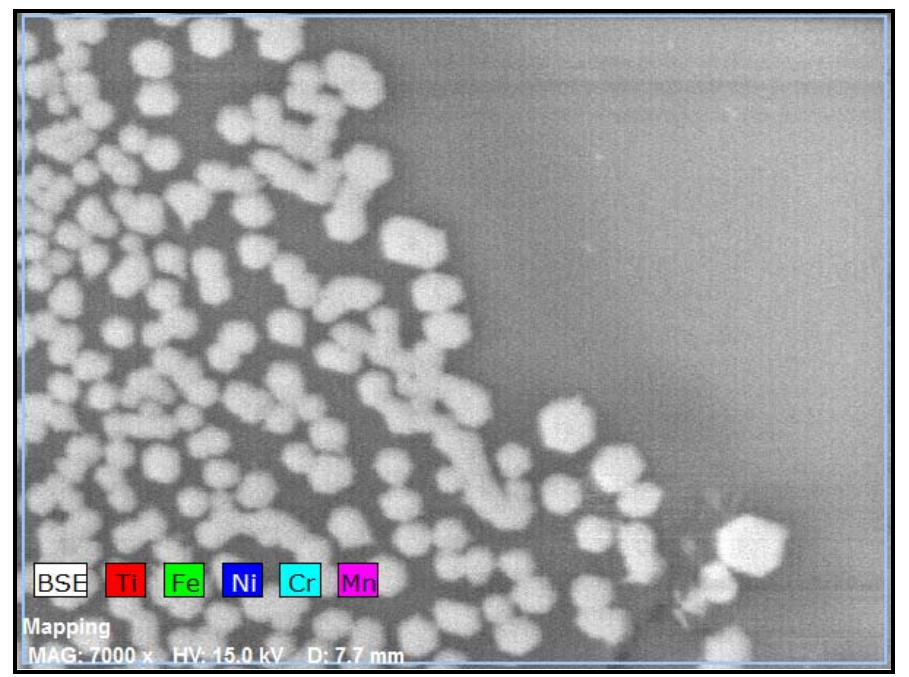

Backscattered Electron Micrograph

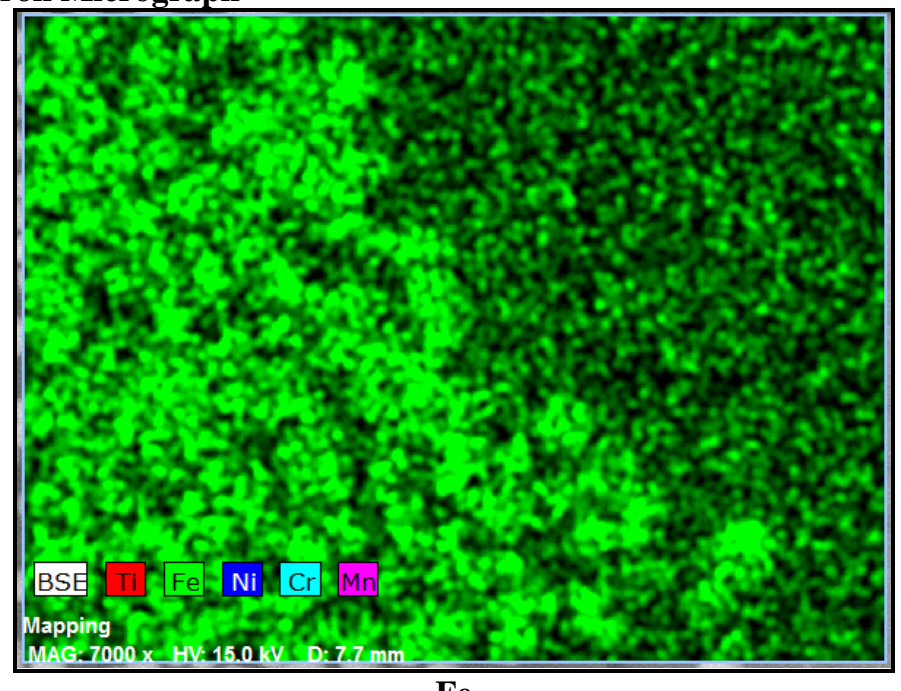

Fe

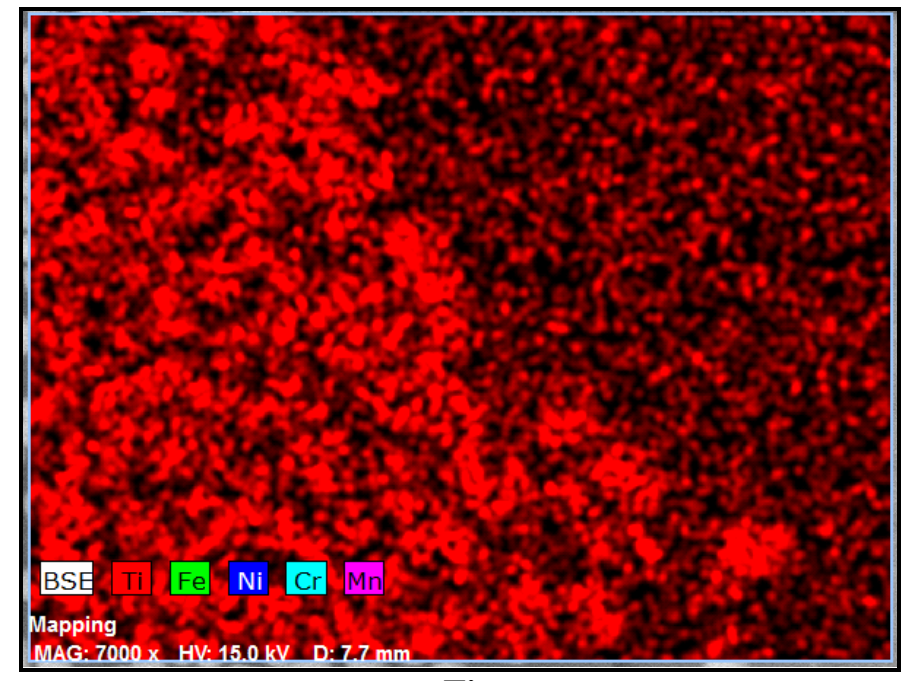

Ti

Figure 3-3. Electron Micrograph and Corresponding EDS Maps of the CCC Version of Glass KT05-08. 


\subsubsection{KT06-Series}

Visual observations of the quenched versions of the KT06-series glasses identified no visible crystallization on any of the glasses. All of the quenched glasses were amorphous by XRD as well. Visual observations of the CCC versions of the KT06 glasses identified varying degrees of surface crystallization on all of the glasses. Several of the glasses were also crystallized in the bulk. The observations of crystallization within the bulk of the CCC glasses agreed well with the XRD results shown in Table 3-2. Those glasses where only surface crystallization was visible were amorphous by XRD, indicating that the volume fraction of the visible crystallization was very small.

Table 3-2. XRD Results for the CCC Versions of the KT06-Series Glasses.

\begin{tabular}{||l|l|}
\hline \multicolumn{1}{|c|}{ Glass } & \multicolumn{1}{c|}{ XRD Results } \\
\hline KT06-01 & Amorphous \\
\hline KT06-02 & Possible Trevorite $\left(\mathrm{NiFe}_{2} \mathrm{O}_{4}\right)$ \\
\hline KT06-03 & Amorphous \\
\hline KT06-04 & Trevorite $\left(\mathrm{NiFe}_{2} \mathrm{O}_{4}\right)$, Unidentified Phase \\
\hline KT06-05 & Hematite $\left(\mathrm{Fe}_{2} \mathrm{O}_{3}\right)$ \\
\hline KT06-06 & Hematite $\left(\mathrm{Fe}_{2} \mathrm{O}_{3}\right)$ \\
\hline KT06-07 & Trevorite $\left(\mathrm{NiFe}_{2} \mathrm{O}_{4}\right)$, Unidentified Phase \\
\hline KT06-08 & Amorphous \\
\hline KT06-09 & Amorphous \\
\hline KT06-10 & Amorphous \\
\hline KT06-11 & Hematite $\left(\mathrm{Fe}_{2} \mathrm{O}_{3}\right)$, Unidentified Phase \\
\hline KT06-12 & Hematite $\left(\mathrm{Fe}_{2} \mathrm{O}_{3}\right)$ \\
\hline KT06-13 & Amorphous \\
\hline KT06-14 & Hematite $\left(\mathrm{Fe}_{2} \mathrm{O}_{3}\right)$, Unidentified Phase \\
\hline KT06-15 & Amorphous \\
\hline KT06-16 & Amorphous \\
\hline KT06-17 & Amorphous \\
\hline KT06-18 & Hematite $\left(\mathrm{Fe}_{2} \mathrm{O}_{3}\right)$, Unidentified Phase \\
\hline
\end{tabular}

No titanium-containing crystalline phases were identified in the $\mathrm{CCC}$ versions of the KT06-series glasses by XRD. As shown in Table 3-2, only Trevorite $\left(\mathrm{NiFe}_{2} \mathrm{O}_{4}\right)$ and Hematite $\left(\mathrm{Fe}_{2} \mathrm{O}_{3}\right)$ were found. However, diffraction peaks corresponding to a phase that could not be identified were also present for several of the glasses. These glasses were further examined by SEM/EDS. A micrograph of the CCC version of glass KT06-04 is shown in Figure 3-4. Crystals are visible as small, white, dendritic shapes distributed throughout the glass. The size of these crystals was too small to get good elemental information via EDS. Larger crystals were present in the CCC version of glass KT06-07, as shown in Figure 3-5. EDS mapping shows that some of the crystals contain higher concentrations of $\mathrm{Ti}$, in addition to Fe and Ni. Narrow, elongated crystals were visible in the CCC versions of glasses KT06-11, -14, and -18. An image from the CCC version of glass KT06-14 is shown in Figure 3-6 as an example. EDS again shows that the crystals contain $\mathrm{Ti}$ in addition to Fe oxide. As will be discussed further in Section 3.3, the crystallization identified in these CCC glasses did not impact chemical durability. 


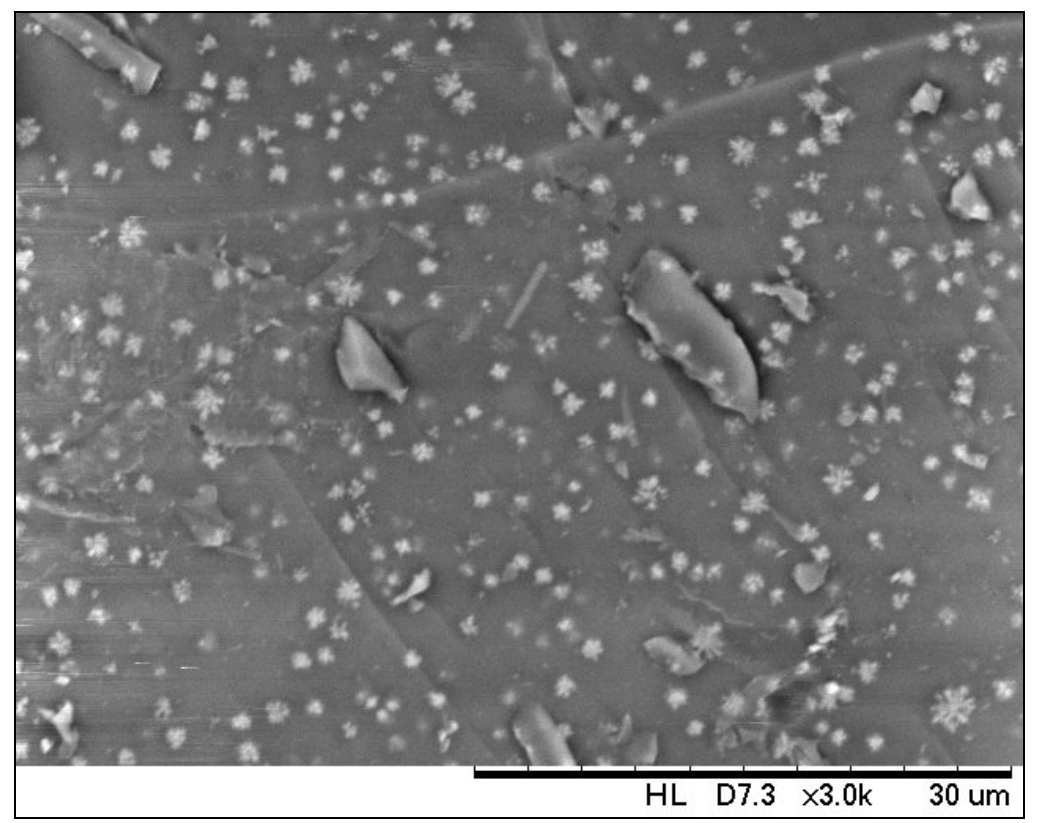

Figure 3-4. Backscattered Electron Micrograph of the CCC Version of Glass KT06-04. 

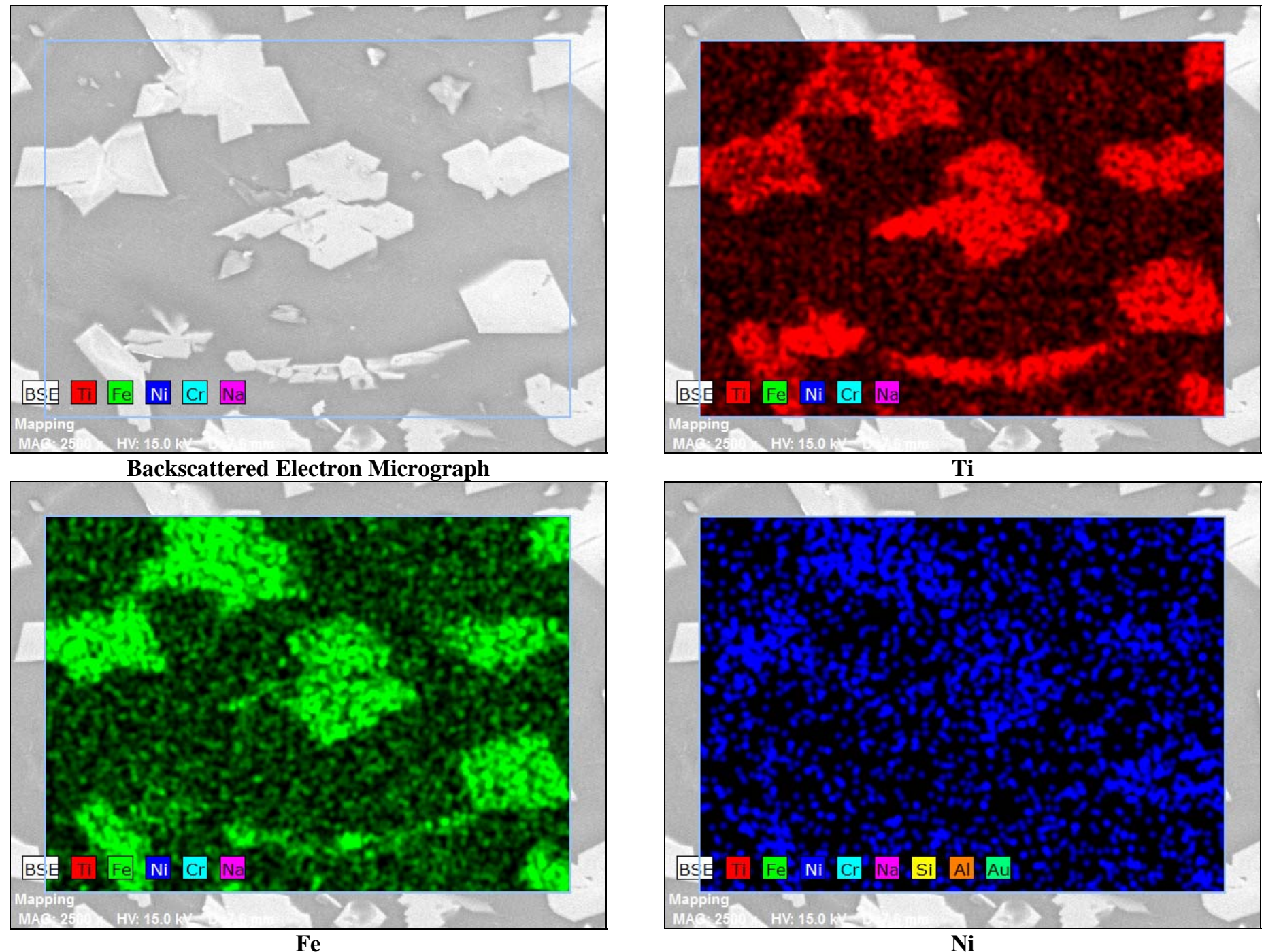

Figure 3-5. Electron Micrograph and Corresponding EDS Maps of the CCC Version of Glass KT06-07. 


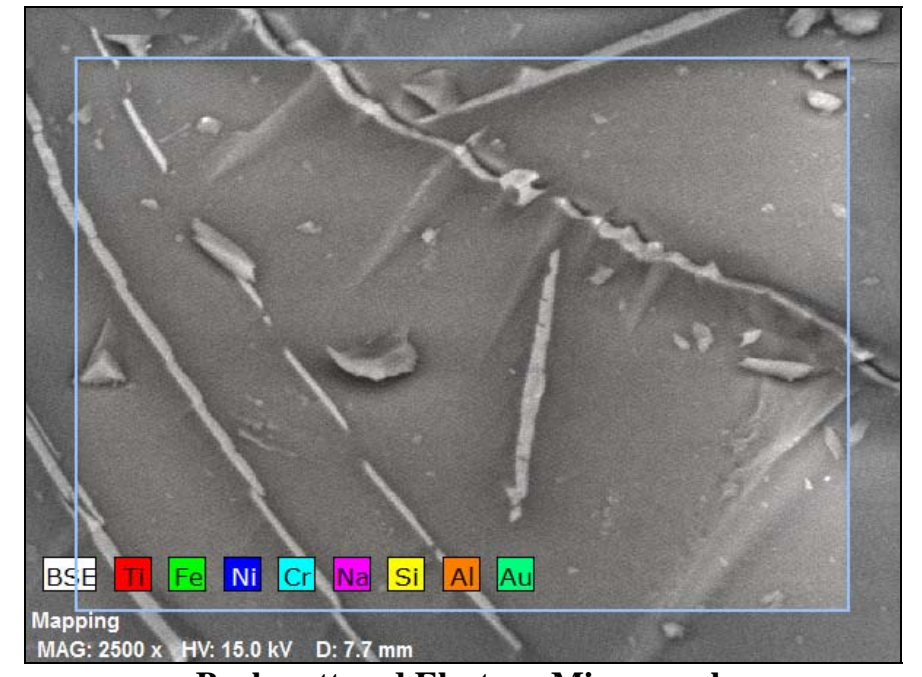

Backscattered Electron Micrograph
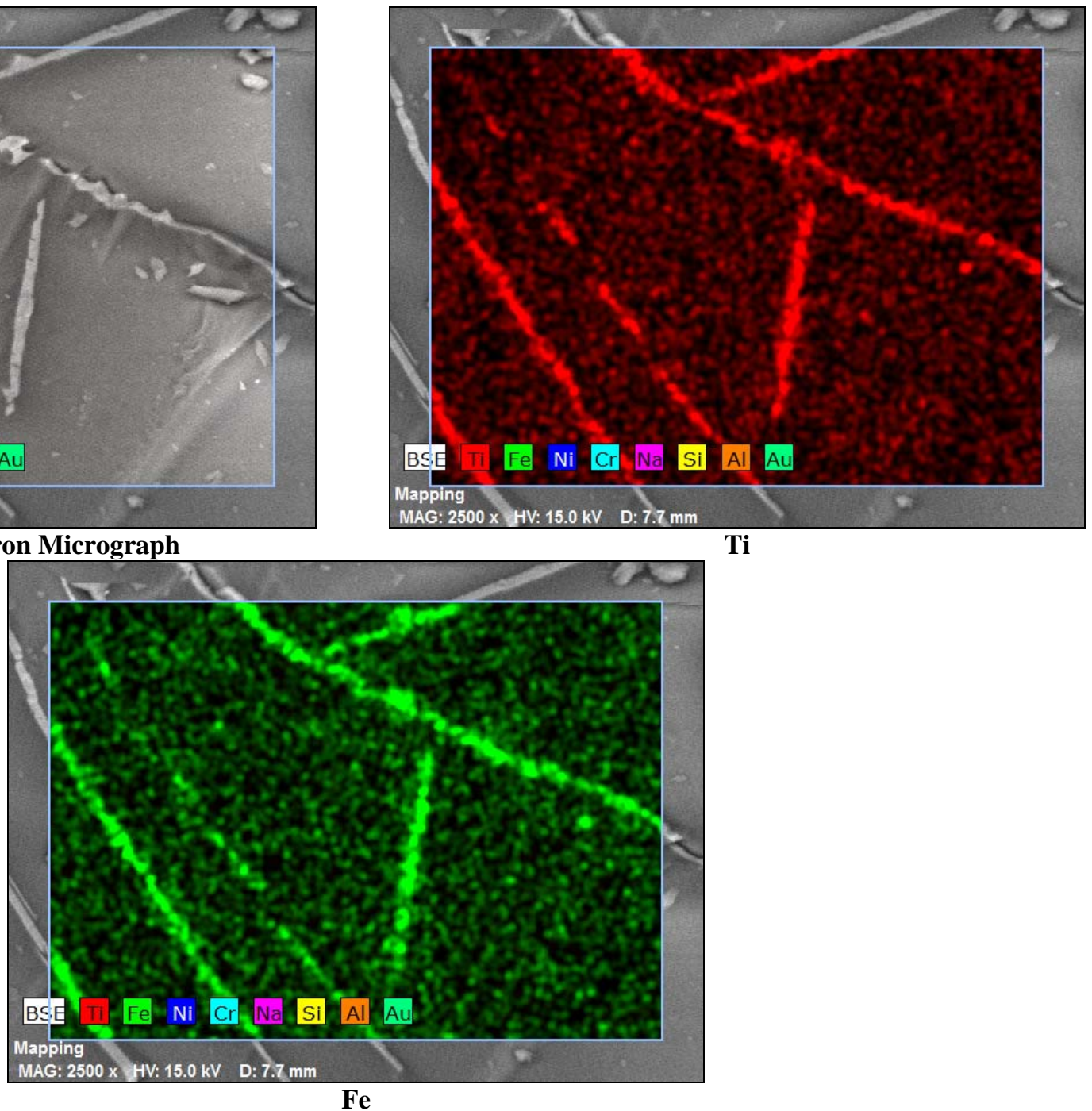

$\mathrm{Ti}$

Figure 3-6. Electron Micrograph and Corresponding EDS Maps of the CCC Version of Glass KT06-14. 


\subsection{Chemical Composition}

In this section, the measured versus targeted compositions of the study glasses are presented and compared. Measurements for samples of the Batch 1 standard glass that were included in the analytical plan along with the study glasses are also discussed. The elemental concentrations were converted to oxide concentrations by multiplying the values for each element by the gravimetric factor for the corresponding oxide. During this process, an elemental concentration that was determined to be below the detection limit of the analytical procedures used was reduced to half of that detection limit as the oxide concentration was determined. In the discussion that follows, the analytical sequences of the measurements are explored, the measurements of the standard are investigated, the measurements for each glass are reviewed, the average chemical compositions for each glass are determined, and comparisons are made between the measurements and the targeted compositions of the glasses.

Table A-1 and Table A-2 in Appendix A provide the elemental concentration measurements from the KT06 glasses that were prepared using LM, and Table A-3 in Appendix A provides the measurements from the samples of these glasses prepared using PF. Measurements for samples of the standard Batch 1 glass that were included in the analytical plan along with the study glasses are also provided in these tables. Exhibit A-1 in Appendix A provides plots of the sample measurements generated by PSAL for each oxide over both preparation methods. The plots are in analytical sequence with different symbols and colors being used to represent each of the study glasses and the standard glass. In general, there does not appear to be any gross patterns or trends due to the analytical sequence. Further opportunity for a review of the measurements for each glass is provided in the discussions that follow.

Exhibit A-2 in Appendix A provides plots of the oxide concentration measurements by Glass ID (including the Batch 1 standard) by analytical solution or Lab ID for both preparation methods for the KT06-series. The different symbols and colors being used to represent the glasses are discernable in this exhibit. These plots show the individual measurements across the duplicates of each preparation method and the two ICP-AES calibrations for each glass for each oxide. The results are grouped by analytical block and arranged by targeted concentration to facilitate the interpretation of the measurements. A review of the plots presented in this exhibit reveals the repeatability of the four individual values for each oxide for each glass. There appears to be good repeatability of these measurements for each of the oxides for each of the glasses. The measured $\mathrm{TiO}_{2}$ values appear to be low for the first preparation of glass KT06-16. The measured $\mathrm{ZrO}_{2}$ values appear to be low for the second preparation of glass KT06-01. Overall, the data suggest no significant issues with the batching of the KT06 glasses or with the analytical process used to provide representative measurements of their compositions.

Exhibit A-3 in Appendix A provides statistical analyses of the results for the Batch 1 standard that was included with the KT06 glasses by analytical block/sub-block for each oxide of interest over both preparation methods. The results include analysis of variance (ANOVA) investigations looking for statistically significant differences among the means of these groups for each of the oxides. The reference values for the oxide concentrations of the standard are given in the header for each set of measurements in the exhibit. The results from the statistical tests for the Batch 1 standard included with the KT06 glasses may be summarized as follows: $\mathrm{BaO}, \mathrm{Cr}_{2} \mathrm{O}_{3}, \mathrm{MnO}, \mathrm{TiO}_{2}$, and $\mathrm{ZrO}_{2}$ have measurements that indicate an ICP-AES calibration effect on the block averages at the $5 \%$ significance level. While statistically significant, the practical impact of these calibration effects is minimal. 
All of the measurements for each oxide for each KT06 glass (i.e., all of the measurements in Appendix A Table A-1, Table A-2, and Table A-3) were averaged to determine a representative chemical composition for each glass. A sum of oxides was also computed for each glass based upon the measured values. Exhibit A-4 in Appendix A provides plots showing results for each glass for each oxide to help highlight the comparisons among the measured and targeted values. Some observations from the plots of Exhibit A-4 are offered: The $\mathrm{Al}_{2} \mathrm{O}_{3}$ and $\mathrm{CuO}$ concentrations are slightly high for some of the study glasses. The $\mathrm{B}_{2} \mathrm{O}_{3}$ and $\mathrm{Fe}_{2} \mathrm{O}_{3}$ concentrations show minor deviations from the target values. The $\mathrm{Na}_{2} \mathrm{O}$ concentrations show more significant deviations from the target values. The $\mathrm{BaO}, \mathrm{La}_{2} \mathrm{O}_{3}$, and $\mathrm{Li}_{2} \mathrm{O}$ concentrations are slightly low for all of the study glasses. The $\mathrm{SiO}_{2}$ concentrations are low for all of the study glasses. The $\mathrm{CaO}$ concentrations are slightly high for all of the study glasses. The $\mathrm{Cr}_{2} \mathrm{O}_{3}, \mathrm{Nb}_{2} \mathrm{O}_{5}, \mathrm{NiO}, \mathrm{PbO}$, and $\mathrm{ZrO}_{2}$ concentrations are slightly low for some of the study glasses. The $\mathrm{K}_{2} \mathrm{O}$ concentration is low for the Batch 1 standard. All of the $\mathrm{SO}_{4}{ }^{2-}$ measurements are below the analytical detection limit. The sum of oxides is low for all of the study glasses, but remains greater than the PCCS minimum of $95 \%$ in all cases. In general, there appear to have been only minor difficulties in meeting the targeted concentrations for the KT06 glasses, none of which should impact the outcome of the study.

Table A-4 in Appendix A provides a summary of the average measured compositions as well as the targeted compositions and the associated differences and relative differences. Note that the targeted sum of oxides for the Batch 1 standard does not sum to $100 \%$ due to an incomplete coverage of the oxides in this glass. All of the sums of oxides for the KT06 glasses fall within the PCCS acceptable interval of 95 to $105 \mathrm{wt} \%$. Entries in Table A-4 show the relative differences between the measured values and the targeted values. These differences are shaded when they are greater than or equal to 5\%. Overall, these comparisons between the measured and targeted compositions again suggest only minor difficulties in meeting the targeted compositions for the KT06 glasses. A MAR assessment using the measured compositions of the KT06 glasses showed that each composition was PCCS acceptable except for the current $\mathrm{TiO}_{2}$ constraint.

\subsection{Durability}

The measurements generated by the PCTs are presented and reviewed in the following sections. For each series of glasses below, the analytical sequence of the measurements is explored, the measurements of the standards are investigated and used to assess the overall accuracy of the ICP-AES measurement process, the measurements for each glass are reviewed, plots are provided that explore the effects of heat treatment on the PCTs for these glasses, the PCTs are normalized using the compositions (targeted and measured) discussed in Section 3.2, and the normalized PCTs are compared to durability predictions for these compositions generated from the current DWPF models. ${ }^{3}$

One of the quality control checkpoints for the PCT procedure is solution mass loss over the course of the seven day test. None of the vessels in the KT06 PCTs had any issues with mass loss. The ratio of leachant volume to the mass of ground glass was also confirmed to be correct for each vessel. All of the measurements of the ARM glass fell within the control ranges. ${ }^{11}$

Table B-1 in Appendix B provides the elemental leachate concentration measurements determined by the PSAL for the solution samples generated by the PCTs for the KT06 glasses. The values were adjusted for the dilution factors: the values for the study glasses, the blanks, and the ARM glass in Table B-1 were multiplied by 1.6667 to determine the values in parts per million and the values for EA were multiplied by 16.6667 . Table B-1 also provides the resulting ppm measurements. 
Exhibit B-1 in Appendix B provides plots of the leachate (ppm) concentrations in analytical sequence as generated by the PSAL for all of the data from the KT06 PCTs. Different colors and symbols are used for each of the study glasses and standards. No issues are seen in these plots.

Exhibit B-2 in Appendix B provides analyses of the PSAL measurements of the samples of the multi-element standard solution by analytical set and ICP-AES calibration block for the KT06series. An ANOVA investigating for statistically significant differences among the block averages for these samples for each element of interest is included in the exhibit. A statistically significant (at a 5\% level) difference among the averages of these measurements was indicated for $\mathrm{B}, \mathrm{Li}, \mathrm{Na}$, and $\mathrm{Si}$. However, no attempt was made to bias correct for these effects since averaging the measured concentrations for each set of triplicates in the PCT helps to minimize the impact of any potential ICP-AES bias effects.

Exhibit B-3 in Appendix B provides plots of the leachate concentrations for each type of submitted sample: the study glasses by heat treatment and the standards (EA, ARM, the multielement solution standard, and blanks). The common logarithm plots allow for the assessment of the repeatability of the measurements, which suggest only minor scatter in the triplicate values for some analytes for some of the glasses.

The PCT leachate concentrations were normalized using the target and measured cation compositions of the glasses to obtain $\mathrm{g} / \mathrm{L}$ leachate concentrations following the procedure. ${ }^{9}$ Exhibit B-4 in Appendix B provides scatter plots for these results and offers an opportunity to investigate the consistency in the leaching across the elements for the KT06 glasses. All combinations of the normalizations of the PCTs (i.e., those generated using the targeted and measured compositional views) and both heat treatments are represented in the series of scatter plots. Consistency in the leaching across the elements is typically demonstrated by a high degree of linear correlation among the values for pairs of these elements. The smallest correlation in this plot is that for $\mathrm{Li}$ and $\mathrm{Na}$ with a value of $\sim 87 \%$, indicating relatively linear correlations for all of the element pairs.

Table B-2 in Appendix B summarizes the normalized PCTs for the KT06 glasses. The PCTs are listed by heat treatment and compositional view for each glass. The KT06 glasses all had normalized leachate for boron (NL [B]) values that were well below the $16.695 \mathrm{~g} / \mathrm{L}$ value of the benchmark EA glass. $^{10}$ The highest NL [B] value was for glass KT06-16, with values of 0.595 $\mathrm{g} / \mathrm{L}$ and $0.581 \mathrm{~g} / \mathrm{L}$ for the quenched and CCC versions of this glass, respectively, normalized to the measured composition.

Exhibit B-5 in Appendix B provides plots showing comparisons of the normalized PCT responses for the two heat treatments for each glass. A review of these plots shows only minor differences in normalized release for the KT06 glasses as a function of heat treatment.

The predictability of the KT06 PCT responses was evaluated using the DWPF durability models. The predicted PCT values, determined using the targeted and measured compositions of the KT06 glasses, were compared with the normalized PCT responses. Exhibit B-6 in Appendix B provides plots of the DWPF models for $\mathrm{B}, \mathrm{Li}, \mathrm{Na}$, and $\mathrm{Si}$ that relate the logarithm of the normalized PCT value (for each element of interest) to a linear function of a free energy of hydration term $\left(\Delta \mathrm{G}_{\mathrm{p}}\right.$, in $\mathrm{kcal} / 100 \mathrm{~g}$ glass) derived from all of the compositional views and heat treatments of the KT06 glasses. Prediction limits at a 95\% confidence for an individual PCT result are also plotted along with the linear fit. The EA and ARM results are indicated on these plots as well. The plots show that while all of the glasses have normalized PCT responses that are acceptable relative to the EA glass, several of the compositions have predicted values that fall above the upper $95 \%$ confidence 
prediction limit. A similar lack of fit for model predicted values in this region (values in the more positive direction of $\Delta G_{p}$ ) has been seen in previous studies of DWPF-type glasses. ${ }^{19-21}$

As noted in Section 3.1.2, some of the CCC versions of the KT06-series glasses were found to be partially crystallized. The DWPF durability models are only expected to be applicable to amorphous glasses. Therefore, a second comparison of the measured versus predicted durabilities was made with the crystallized glasses omitted. The resulting plots are shown in Exhibit B-7 in Appendix B, and show that even with the partially crystallized glasses omitted, several of the remaining compositions (both quenched and $\mathrm{CCC}$ ) have predicted values that fall above the upper $95 \%$ confidence prediction limit.

The data were further reviewed to identify any similarities among those KT06 compositions with durabilities that, while acceptable, were not predictable using the current models. Scatter plots of the major oxides using $\mathrm{Fe}_{2} \mathrm{O}_{3}$ as a reference were prepared to look for any trends in composition versus predictability. These plots are shown in Figure 3-7. The $\square$ symbol indicates a composition with a normalized release for boron that was not predictable by the current PCCS durability model, and the $Y$ symbol indicates a composition with a normalized release for boron that was predictable by the model. The plots of Figure 3-7 demonstrate that there is no single oxide that clearly partitions the unpredictable compositions from the predictable compositions. 


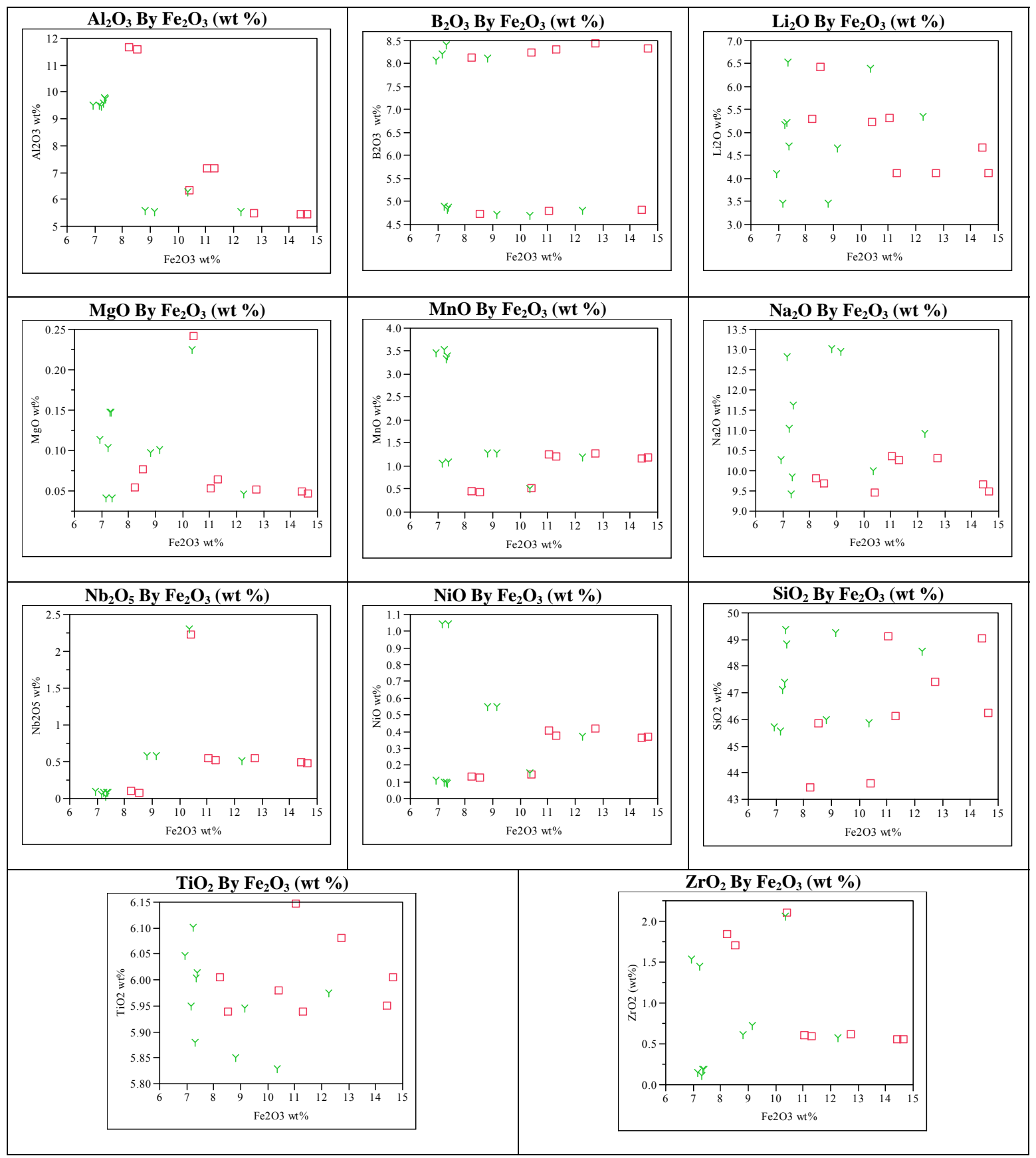

Figure 3-7. Scatter Plots of the Major Oxides of the KT06-Series Glasses Prepared to Identify Any Compositional Impacts on Predictability of Chemical Durability.

Partitioning of the data using a statistical analysis software package was completed as an additional effort to identify any similarities among the KT06-series glasses with durabilities that were not predictable by the current models. The oxides $\mathrm{Al}_{2} \mathrm{O}_{3}, \mathrm{~B}_{2} \mathrm{O}_{3}, \mathrm{CaO}, \mathrm{Fe}_{2} \mathrm{O}_{3}, \mathrm{Li}_{2} \mathrm{O}, \mathrm{MgO}$, $\mathrm{MnO}, \mathrm{Na}_{2} \mathrm{O}, \mathrm{Nb}_{2} \mathrm{O}_{5}, \mathrm{NiO}, \mathrm{SiO}_{2}, \mathrm{TiO}_{2}$, and $\mathrm{ZrO}_{2}$ were activated in this partitioning as these oxides were present in the most significant concentrations. The outcome from the execution of the partitioning routine is given in Figure 3-8. It shows that the KT06-series glasses that have relatively high $\mathrm{Fe}_{2} \mathrm{O}_{3}$ concentrations (greater than 8.2 wt \%) and relatively high $\mathrm{Al}_{2} \mathrm{O}_{3}$ 
concentrations (greater than $6.3 \mathrm{wt} \%$ ) have durabilities that are unpredictable. The glasses with lower $\mathrm{Fe}_{2} \mathrm{O}_{3}$ concentrations are all predictable by the current models. Those with relatively high $\mathrm{Fe}_{2} \mathrm{O}_{3}$ concentrations but $\mathrm{Al}_{2} \mathrm{O}_{3}$ concentrations less than $6.3 \mathrm{wt} \%$ had a mix of predictable and unpredictable durabilities, although all of the durability values were acceptable.

Repeating the scatter plot of $\mathrm{Al}_{2} \mathrm{O}_{3}$ versus $\mathrm{Fe}_{2} \mathrm{O}_{3}$ concentrations from Figure 3-7 in the right-side of Figure 3-8, the pattern in unpredictable versus predictable durabilities as a function of these two components is visible. This response can be explained in that $\mathrm{Al}_{2} \mathrm{O}_{3}$ and $\mathrm{Fe}_{2} \mathrm{O}_{3}$ both have positive $\Delta \mathrm{G}_{\mathrm{i}}$ values, which in turn give a more positive $\Delta \mathrm{G}_{\mathrm{p}}$ value for the glass composition. A glass with relatively high $\mathrm{Al}_{2} \mathrm{O}_{3}$ and $\mathrm{Fe}_{2} \mathrm{O}_{3}$ concentrations will tend to have a $\Delta \mathrm{G}_{\mathrm{p}}$ value that is shifted more to the right on the plots shown in Exhibit B-6 of Appendix B. With enough of an increase in $\mathrm{Al}_{2} \mathrm{O}_{3}$ and $\mathrm{Fe}_{2} \mathrm{O}_{3}$ concentrations, the $\Delta \mathrm{G}_{\mathrm{p}}$ value can be pushed outside of the $95 \%$ confidence bounds of the current models, resulting in a durability value that is not predictable but is acceptable relative to the EA glass.

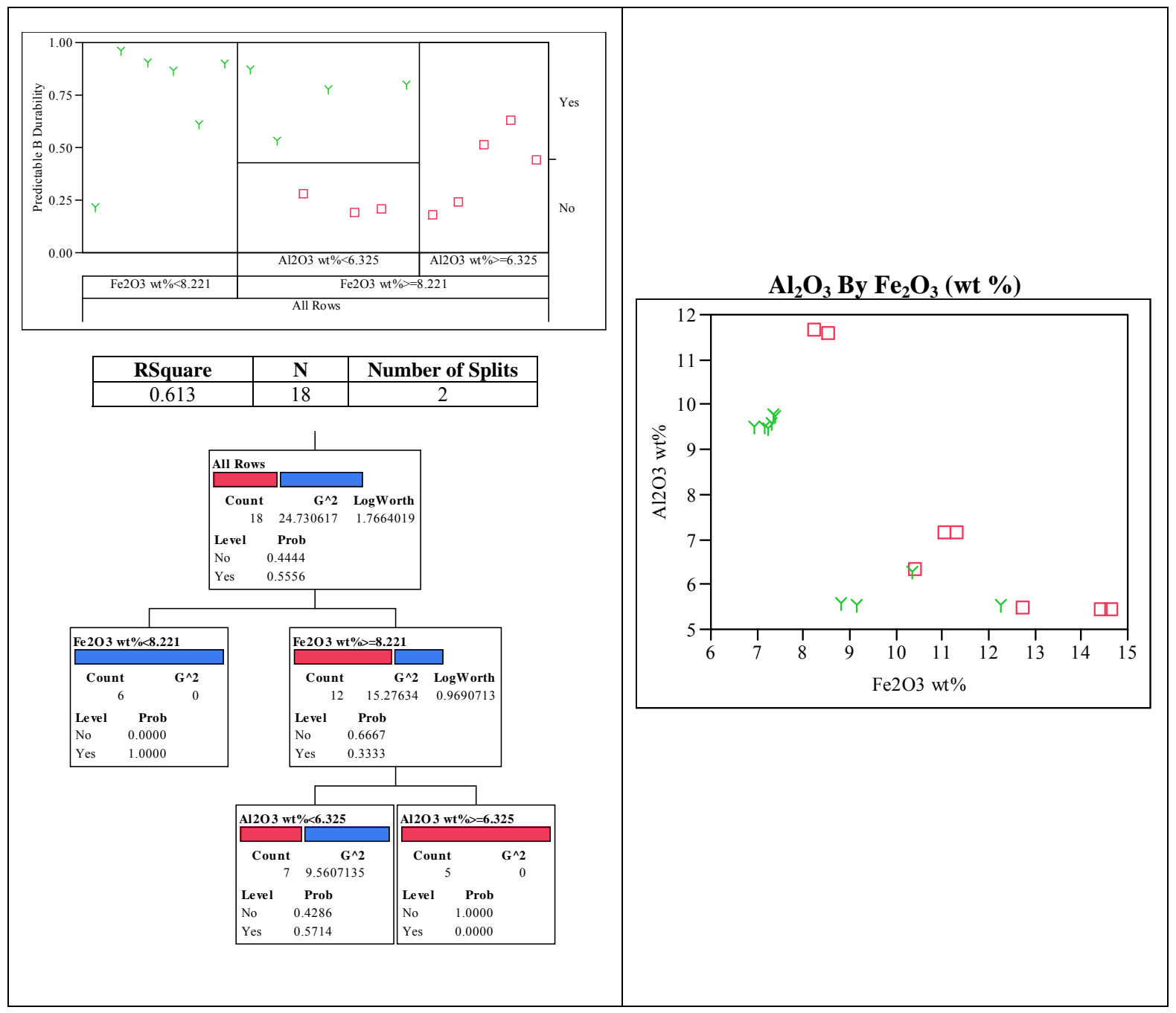

Figure 3-8. Outcome of the Partitioning Routine for Chemical Composition and Predictability of Chemical Durability for the KT06-Series Glasses. 


\subsection{Viscosity}

Viscosity data were collected for all of the glasses in the KT06-series. The viscosity values showed no evidence of volatilization or crystallization during the measurements. The measured viscosity at $1150{ }^{\circ} \mathrm{C}$ was determined by fitting the data for each glass to the Fulcher equation. ${ }^{17,18}$ Complete data from the fitting of Fulcher equations are given in Exhibit C-1 in Appendix C. The results of the Fulcher fits were used to calculate a measured viscosity value for each glass at $1150{ }^{\circ} \mathrm{C}$. These values are given in Exhibit C-2 in Appendix C. The measured values are displayed graphically versus the model predictions in Exhibit C-3 in Appendix C. The table and plot show that there were mixed results for the KT06-series glasses in terms of the measured viscosities being predictable by the current model. The model generally over predicted the measured viscosity values. Several of the values fell below the lower $95 \%$ confidence bound of the model prediction.

The viscosity results were further evaluated to identify any compositional trends among the KT06-series glasses that led to unpredictable viscosity values. Scatter plots of the major oxides using $\mathrm{Fe}_{2} \mathrm{O}_{3}$ as a reference were prepared to look for any trends in composition versus predictability. These plots are shown in Figure 3-9. The $\square$ symbol indicates a composition with a viscosity value that was not predictable by the current PCCS model, and the Y symbol indicates a composition with a viscosity value that was predictable by the model. A review of the plots shows a clear delineation between the glasses with predictable and unpredictable viscosities based on their $\mathrm{Fe}_{2} \mathrm{O}_{3}$ concentrations, regardless of the concentrations of the other oxides. 


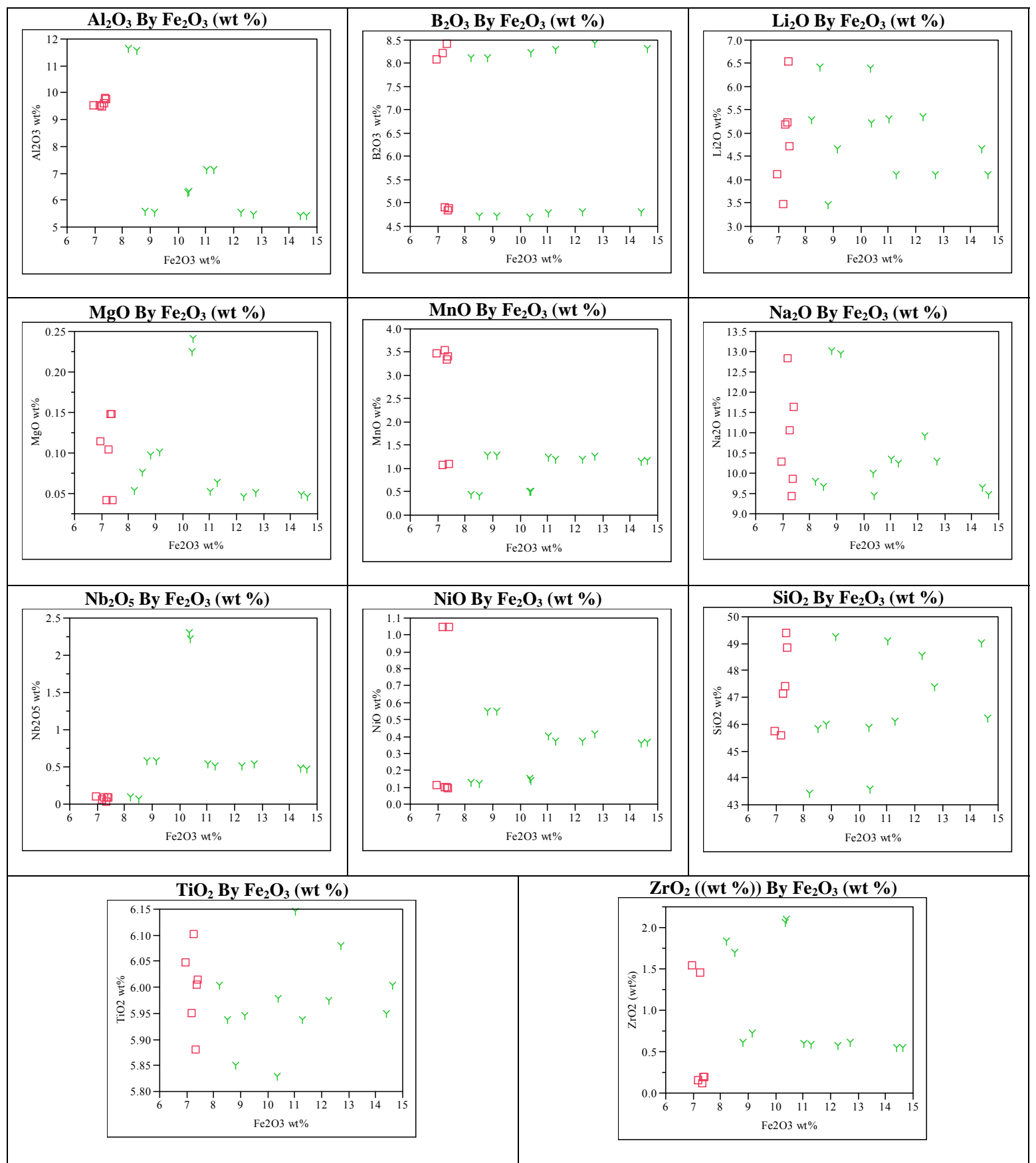

Figure 3-9. Scatter Plots of the Major Oxides of the KT06-Series Glasses Prepared to Identify Any Compositional Impacts on Predictability of Viscosity.

These observations were confirmed by partitioning of the data. The oxides $\mathrm{Al}_{2} \mathrm{O}_{3}, \mathrm{~B}_{2} \mathrm{O}_{3}, \mathrm{CaO}$, $\mathrm{Fe}_{2} \mathrm{O}_{3}, \mathrm{Li}_{2} \mathrm{O}, \mathrm{MgO}, \mathrm{MnO}, \mathrm{Na}_{2} \mathrm{O}, \mathrm{Nb}_{2} \mathrm{O}_{5}, \mathrm{NiO}, \mathrm{SiO}_{2}, \mathrm{TiO}_{2}$, and $\mathrm{ZrO}_{2}$ were activated in this partitioning as these oxides were present in the most significant concentrations. The outcome from the execution of the partitioning routine is given in Figure 3-10. The $\mathrm{Fe}_{2} \mathrm{O}_{3}$ concentrations of the KT06-series glasses allow for a complete partitioning of the predictable versus unpredictable viscosities. The measured viscosities become unpredictable by the current model when the $\mathrm{Fe}_{2} \mathrm{O}_{3}$ concentration in the glasses is less than about $8.2 \mathrm{wt} \%$. 


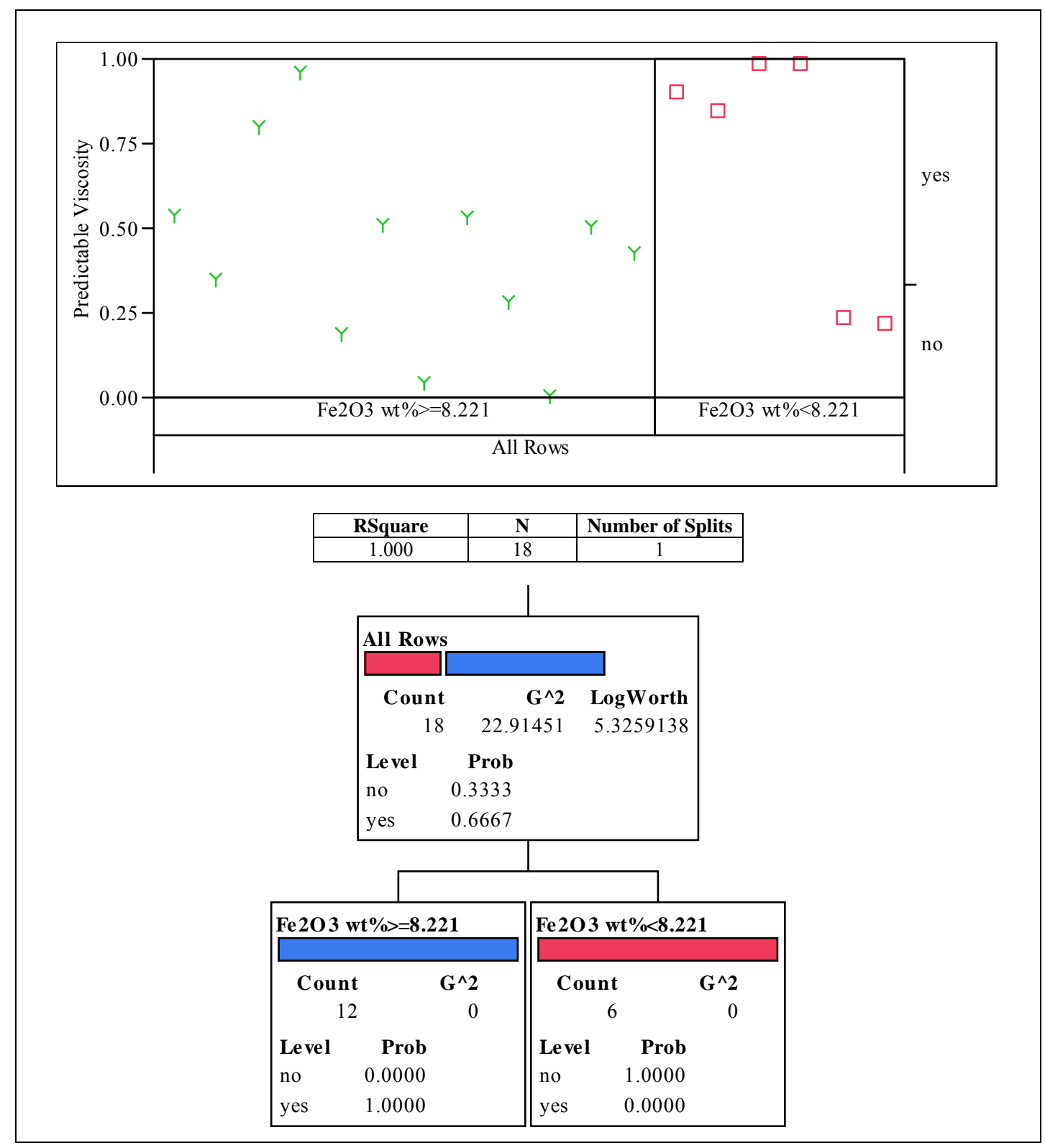

Figure 3-10. Outcome of the Partitioning Routine for Chemical Composition and Predictability of Viscosity for the KT06-Series Glasses. 


\subsection{Summary}

The KT05-series glasses were selected, fabricated, and characterized to further study HLW glass compositions where iron titanate crystals had been found to form. The intent was to better understand the mechanisms and compositions that favored the formation of crystals containing titanium. Formation of these crystalline phases was confirmed. Increased $\mathrm{Na}_{2} \mathrm{O}$ concentrations had little if any impact on reducing the propensity for the formation of the iron titanate crystalline phases. Other physical properties of these glasses were not measured since the intent was to focus on crystallization.

The KT06-series glasses were selected, fabricated, and characterized to further study HLW glass compositions that, while broader than the current projections for DWPF feeds with SCIX material, are potential candidates for future processing (i.e., the compositions are acceptable for processing by PCCS with the exception of the current $\mathrm{TiO}_{2}$ concentration constraint). The chemical compositions of these glasses matched well with the target values. The chemical durabilities of all the glasses were acceptable relative to the EA benchmark. Minor crystallization was identified in some of the slowly cooled glasses, although this crystallization did not impact chemical durability. Measurements of the liquidus temperatures of the KT06-series glasses are underway at the time of this report. The data will be reported separately.

Several of the KT06-series compositions had durability values that, while acceptable, were not accurately predicted by the current PCCS models. A similar lack of fit for model predicted durabilities for glasses with more positive $\Delta \mathrm{G}_{\mathrm{p}}$ values has been seen in previous studies of DWPF-type glasses. It was shown that for the high $\mathrm{TiO}_{2}$ concentration glasses $\left(6 \mathrm{wt} \% \mathrm{TiO}_{2}\right)$ in this study, relatively high $\mathrm{Fe}_{2} \mathrm{O}_{3}$ concentrations combined with relatively high $\mathrm{Al}_{2} \mathrm{O}_{3}$ concentrations led to durabilities that were unpredictable. The current durability models will have to be further evaluated should compositions in this region become necessary for DWPF processing.

Several of the KT06-series glasses also had measured viscosity values that were not well predicted by the current model. A statistical partitioning routine showed that the measured viscosities became unpredictable by the current model when the $\mathrm{Fe}_{2} \mathrm{O}_{3}$ concentration in the glasses was less than about $8.2 \mathrm{wt} \%$ at the elevated $\mathrm{TiO}_{2}$ concentrations. The current viscosity model will have to be further evaluated should compositions in this region become necessary for DWPF processing.

\subsection{Recommendations and Path Forward}

The baseline compositions in the KT05-series should be further investigated to identify the potential influence of increased $\mathrm{K}_{2} \mathrm{O}$ and $\mathrm{Al}_{2} \mathrm{O}_{3}$ concentrations on hindering the formation of titanium-containing crystalline phases. Liquidus temperature measurements will continue, and the results will be presented in a separate technical report. The potential impacts of noble metals on crystallization in glasses with increased $\mathrm{TiO}_{2}$ concentrations will be investigated through the KT07-series glasses. The potential impacts of $\mathrm{ThO}_{2}$ and $\mathrm{U}_{3} \mathrm{O}_{8}$ (as well as noble metals) on the properties and performance of glasses with increased $\mathrm{TiO}_{2}$ concentrations will be investigated through the KT08-series glasses. Both the KT07 and KT08-series have been fabricated, and characterization is now underway.

At the completion of this series of studies, all of the data generated will be reviewed with regard to applicability of the DWPF PCCS model and recommendations will be made as to whether the validation ranges of the current models can be extended, or whether some or all of the models need to be refit to allow for the incorporation of the SCIX streams coupled with the current 
sludge batch projections. As changes are made to the projected sludge compositions and the volume of the SCIX material, additional evaluations should be performed.

\subsection{References}

1. Fellinger, T. L., "Technical Task Request: DWPF Glass Evaluation for the Introduction of MSP Products into Future Sludge Batches," U.S. Department of Energy Report HLW-DWPFTTR-2010-0009, Revision A, Savannah River Remediation, Aiken, SC (2010).

2. Fox, K. M., "Task Technical and Quality Assurance Plan for Evaluation of the Introduction of Modular Salt Processing Products to Defense Waste Processing Facility Glass for Future Sludge Batches," U.S. Department of Energy Report SRNL-RP-2010-00560, Revision 0, Savannah River National Laboratory, Aiken, SC (2010).

3. Edwards, T. B., K. G. Brown and R. L. Postles, "SME Acceptability Determination for DWPF Process Control," U.S. Department of Energy Report WSRC-TR-95-00364, Revision 5, Washington Savannah River Company, Aiken, SC (2006).

4. Fox, K. M., T. B. Edwards, M. E. Stone and D. C. Koopman, "Paper Study Evaluations of the Introduction of Small Column Ion Exchange (SCIX) Waste Streams to the Defense Waste Processing Facility," U.S. Department of Energy Report SRNL-STI-2010-00297, Revision 0, Savannah River National Laboratory, Aiken, SC (2010).

5. Fox, K. M. and T. B. Edwards, "Impacts of Small Column Ion Exchange Streams on DWPF Glass Formulation: KT01, KT02, KT03, and KT04-Series Glass Compositions," U.S. Department of Energy Report SRNL-STI-2010-00566, Revision 0, Savannah River National Laboratory, Aiken, SC (2010).

6. Johnson, F. C. and T. B. Edwards, "Results of the FY09 Enhanced DOE High-Level Waste Melter Throughput Studies at SRNL," U.S. Department of Energy Report SRNL-STI-2009-00778, Revision 0, Savannah River National Laboratory, Aiken, SC (2010).

7. Marra, S. L. and C. M. Jantzen, "Characterization of Projected DWPF Glass Heat Treated to Simulate Canister Centerline Cooling," U.S. Department of Energy Report WSRC-TR-92-142, Revision 1, Westinghouse Savannah River Company, Aiken, SC (1993).

8. Edwards, T. B., "An Analytical Plan for Measuring the Chemical Compositions of the KT06Series of Glasses from the Study of the Impact of SCIX Streams on DWPF Wasteforms," U.S. Department of Energy Memorandum SRNL-L5200-2010-00029, Savannah River National Laboratory, Aiken, SC (2010).

9. ASTM, "Standard Test Methods for Determining Chemical Durability of Nuclear Waste Glasses: The Product Consistency Test (PCT)," ASTM C-1285, (2002).

10. Jantzen, C. M., N. E. Bibler, D. C. Beam, C. L. Crawford and M. A. Pickett, "Characterization of the Defense Waste Processing Facility (DWPF) Environmental Assessment (EA) Glass Standard Reference Material," U.S. Department of Energy Report WSRC-TR-92-346, Revision 1, Westinghouse Savannah River Company, Aiken, SC (1993).

11. Jantzen, C. M., J. B. Picket, K. G. Brown, T. B. Edwards and D. C. Beam, "Process/Product Models for the Defense Waste Processing Facility (DWPF): Part I. Predicting Glass Durability 
from Composition Using a Thermodynamic Hydration Energy Reaction Model (THERMO)," U.S. Department of Energy Report WSRC-TR-93-672, Revision 1, Westinghouse Savannah River Company, Aiken, SC (1995).

12. Edwards, T. B., "An Analytical Plan for Measuring the PCT Solutions of the KT06 Series of SCIX Streams on DWPF Wasteforms," U.S. Department of Energy Memorandum SRNL-L52002010-00032, Savannah River National Laboratory, Aiken, SC (2010).

13. ASTM, "Standard Practice for Measuring Viscosity of Glass Above the Softening Point," ASTM C-965, (2007).

14. Schumacher, R. F. and D. K. Peeler, "Establishment of Harrop, High-Temperature Viscometer," U.S. Department of Energy Report WSRC-RP-98-00737, Revision 0, Westinghouse Savannah River Company, Aiken, SC (1998).

15. Schumacher, R. F., R. J. Workman and T. B. Edwards, "Calibration and Measurement of the Viscosity of DWPF Start-Up Glass," U.S. Department of Energy Report WSRC-RP-2000-00874, Revision 0, Westinghouse Savannah River Company, Aiken, SC (2001).

16. Crum, J. V., R. L. Russell, M. J. Schweiger, D. E. Smith, J. D. Vienna, T. B. Edwards, C. M. Jantzen, D. K. Peeler, R. F. Schumacher and R. J. Workman, "DWPF Startup Frit Viscosity Measurement Round Robin Results," Pacific Northwest National Laboratory, (Unpublished).

17. Fulcher, G. S., "Analysis of Recent Measurements of the Viscosity of Glasses," Journal of the American Ceramic Society, 8 [6] 339-355 (1925).

18. Fulcher, G. S., "Analysis of Recent Measurements of the Viscosity of Glasses, II," Journal of the American Ceramic Society, 8 [12] 789-794 (1925).

19. Harbour, J. R., T. B. Edwards and R. J. Workman, "Summary of Results for Macrobatch 3 Variability Study," U.S. Department of Energy Report WSRC-TR-2000-00351, Revision 0, Westinghouse Savannah River Company, Aiken, SC (2000).

20. Fox, K. M., T. B. Edwards, D. K. Peeler, D. R. Best, I. A. Reamer and R. J. Workman, "Durability and Nepheline Crystallization Study for High Level Waste (HLW) Sludge Batch 4 (SB4) Glasses Formulated with Frit 503," U.S. Department of Energy Report WSRC-STI-200600009, Revision 0, Washington Savannah River Company, Aiken, SC (2006).

21. Fox, K. M., T. B. Edwards, D. K. Peeler, D. R. Best, I. A. Reamer and R. J. Workman, "High Level Waste (HLW) Sludge Batch 4 (SB4) Variability Study," U.S. Department of Energy Report WSRC-STI-2006-00204, Revision 0, Washington Savannah River Company, Aiken, SC (2006). 
SRNL-STI-2010-00687

Revision 0

Appendix A. Data Supporting the Chemical Composition Measurements of the KT06-Series Glasses 
Table A-1. PSAL Chemical Composition Measurements of the KT06-Series of Glasses Using LM Preparation Method (Part 1).

\begin{tabular}{|c|c|c|c|c|c|c|c|c|c|c|c|c|}
\hline Glass ID & Block & Sub-Blk & Sequence & Lab ID & Ba (wt\%) & Ca (wt\%) & Ce (wt \%) & Cr (wt\%) & Cu (wt \%) & K (wt\%) & La (wt\%) & Mg (wt\%) \\
\hline Batch 1 & 1 & \begin{tabular}{l|}
1 \\
\end{tabular} & 1 & BCHLM111 & 0.124 & 0.855 & $<0.010$ & 0.074 & 0.317 & 2.228 & $<0.010$ & 0.851 \\
\hline KT06-16 & 1 & 1 & 3 & C03LM11 & 0.054 & 0.536 & 0.242 & 0.084 & 0.037 & 0.121 & 0.073 & 0.089 \\
\hline KT06-13 & 1 & 1 & 5 & C07LM11 & 0.054 & 0.536 & 0.241 & 0.093 & 0.037 & 0.124 & 0.072 & 0.088 \\
\hline KT06-01 & 1 & 1 & 6 & C15LM21 & 0.035 & 0.893 & 0.165 & 0.064 & 0.031 & 0.093 & 0.048 & 0.057 \\
\hline KT06-13 & 1 & 1 & 7 & C07LM21 & 0.055 & 0.530 & 0.252 & 0.092 & 0.037 & 0.115 & 0.075 & 0.090 \\
\hline KT06-11 & 1 & 1 & 10 & C05LM11 & 0.018 & 0.807 & 0.089 & 0.035 & 0.032 & 0.049 & 0.023 & 0.028 \\
\hline Batch 1 & 1 & 1 & 11 & BCHLM112 & 0.119 & 0.892 & $<0.010$ & 0.072 & 0.327 & 2.318 & $<0.010$ & 0.825 \\
\hline KT06-03 & 1 & 1 & 12 & C10LM21 & 0.039 & 0.867 & 0.182 & 0.069 & 0.033 & 0.078 & 0.051 & 0.063 \\
\hline KT06-09 & 1 & 1 & 13 & C18LM21 & 0.017 & 0.808 & 0.089 & 0.035 & 0.015 & 0.050 & 0.025 & 0.028 \\
\hline KT06-01 & 1 & 1 & 14 & C15LM11 & 0.037 & 0.870 & 0.177 & 0.067 & 0.031 & 0.081 & 0.050 & 0.061 \\
\hline KT06-14 & 1 & 1 & 15 & C14LM11 & 0.021 & 1.56 & 0.103 & 0.038 & 0.015 & 0.043 & 0.029 & 0.034 \\
\hline KT06-03 & 1 & 1 & 20 & \begin{tabular}{|l|} 
C10LM11 \\
\end{tabular} & 0.036 & 0.916 & 0.165 & 0.063 & 0.034 & 0.098 & 0.047 & 0.058 \\
\hline Batch 1 & 1 & 1 & 21 & BCHLM113 & 0.120 & 0.895 & $<0.010$ & 0.071 & 0.326 & 2.310 & $<0.010$ & 0.822 \\
\hline Batch 1 & 1 & 2 & 1 & BCHLM121 & 0.122 & 0.870 & $<0.010$ & 0.073 & 0.317 & 2.189 & $<0.010$ & 0.855 \\
\hline KT06-06 & 1 & 2 & 2 & \begin{tabular}{|l|} 
C06LM22 \\
\end{tabular} & 0.018 & 0.782 & 0.097 & 0.039 & 0.032 & 0.040 & 0.024 & 0.032 \\
\hline KT06-03 & 1 & 2 & 3 & C10LM12 & 0.036 & 0.895 & 0.163 & 0.065 & 0.031 & 0.092 & 0.044 & 0.059 \\
\hline KT06-13 & 1 & 2 & 4 & C07LM22 & 0.055 & 0.527 & 0.250 & 0.093 & 0.034 & 0.110 & 0.073 & 0.090 \\
\hline KT06-01 & 1 & 2 & 5 & C15LM22 & 0.034 & 0.896 & 0.164 & 0.062 & 0.029 & 0.091 & 0.046 & 0.056 \\
\hline KT06-16 & 1 & 2 & 6 & C03LM12 & 0.052 & 0.544 & 0.238 & 0.082 & 0.035 & 0.120 & 0.070 & 0.087 \\
\hline KT06-01 & 1 & 2 & 7 & C15LM12 & 0.036 & 0.860 & 0.174 & 0.067 & 0.029 & 0.078 & 0.049 & 0.061 \\
\hline KT06-03 & 1 & 2 & 8 & C10LM22 & 0.038 & 0.855 & 0.179 & 0.069 & 0.030 & 0.074 & 0.048 & 0.063 \\
\hline KT06-11 & 1 & 2 & 9 & C05LM22 & 0.017 & 0.791 & 0.090 & 0.034 & 0.034 & 0.045 & 0.021 & 0.027 \\
\hline KT06-04 & 1 & 2 & 18 & C01LM22 & 0.014 & 1.36 & 0.078 & 0.034 & 0.033 & 0.043 & 0.019 & 0.025 \\
\hline KT06-09 & 1 & 2 & 19 & C18LM12 & 0.017 & 0.785 & 0.091 & 0.036 & 0.013 & 0.042 & 0.022 & 0.028 \\
\hline KT06-09 & 1 & 2 & 20 & C18LM22 & 0.016 & 0.801 & 0.087 & 0.035 & 0.013 & 0.047 & 0.022 & 0.026 \\
\hline Batch 1 & 1 & 2 & 21 & BCHLM123 & 0.120 & 0.877 & $<0.010$ & 0.073 & 0.319 & 2.200 & $<0.010$ & 0.840 \\
\hline Batch 1 & 2 & 1 & 1 & \begin{tabular}{|l|} 
BCHLM211 \\
\end{tabular} & 0.121 & 0.850 & $<0.010$ & 0.073 & 0.315 & 2.109 & $<0.010$ & 0.848 \\
\hline KT06-05 & 2 & 1 & 2 & C12LM21 & 0.013 & 0.755 & 0.090 & 0.038 & 0.012 & 0.041 & 0.024 & 0.028 \\
\hline KT06-18 & 2 & 1 & 3 & C04LM21 & 0.014 & 0.790 & 0.088 & 0.036 & 0.041 & 0.048 & 0.023 & 0.028 \\
\hline KT06-17 & 2 & 1 & 4 & C17LM21 & 0.016 & 1.71 & 0.094 & 0.036 & 0.022 & 0.055 & 0.026 & 0.058 \\
\hline KT06-15 & 2 & 1 & 5 & C16LM11 & 0.084 & 0.759 & 0.363 & 0.115 & 0.065 & 0.149 & 0.112 & 0.137 \\
\hline KT06-05 & 2 & 1 & 6 & C12LM11 & 0.013 & 0.907 & 0.091 & 0.040 & 0.011 & 0.053 & 0.025 & 0.048 \\
\hline KT06-02 & 2 & 1 & 7 & C08LM21 & 0.012 & 1.23 & 0.078 & 0.031 & 0.035 & 0.041 & 0.020 & 0.023 \\
\hline KT06-07 & 2 & 1 & 8 & C11LM21 & 0.038 & 0.530 & 0.192 & 0.068 & 0.026 & 0.075 & 0.055 & 0.067 \\
\hline KT06-15 & 2 & 1 & 9 & C16LM21 & 0.081 & 0.768 & 0.367 & 0.116 & 0.072 & 0.157 & 0.108 & 0.132 \\
\hline KT06-12 & 2 & 1 & 10 & \begin{tabular}{|l|} 
C13LM21 \\
\end{tabular} & 0.075 & 0.975 & 0.338 & 0.113 & 0.056 & 0.197 & 0.098 & 0.149 \\
\hline Batch 1 & 2 & 1 & 11 & BCHLM212 & 0.116 & 0.886 & $<0.010$ & 0.071 & 0.324 & 2.189 & $<0.010$ & 0.815 \\
\hline KT06-18 & 2 & 1 & 12 & C04LM11 & 0.013 & 0.813 & 0.085 & 0.034 & 0.033 & 0.052 & 0.022 & 0.027 \\
\hline KT06-08 & 2 & 1 & 13 & C09LM11 & 0.014 & 0.789 & 0.094 & 0.036 & 0.024 & 0.042 & 0.024 & 0.029 \\
\hline KT06-10 & 2 & 1 & 14 & C02LM11 & 0.037 & 0.528 & 0.183 & 0.069 & 0.044 & 0.079 & 0.052 & 0.063 \\
\hline KT06-17 & 2 & 1 & 15 & C17LM11 & 0.016 & 1.52 & 0.095 & 0.039 & 0.015 & 0.050 & 0.026 & 0.029 \\
\hline KT06-12 & 2 & 1 & 16 & C13LM11 & 0.083 & 0.764 & 0.375 & 0.130 & 0.056 & 0.151 & 0.111 & 0.137 \\
\hline KT06-07 & 2 & 1 & 17 & C11LM11 & 0.037 & 0.533 & 0.188 & 0.067 & 0.025 & 0.075 & 0.053 & 0.066 \\
\hline KT06-02 & 2 & 1 & 18 & C08LM11 & 0.012 & 1.33 & 0.080 & 0.033 & 0.036 & 0.040 & 0.020 & 0.023 \\
\hline KT06-10 & 2 & 1 & 19 & C02LM21 & 0.035 & 0.550 & 0.174 & 0.067 & 0.044 & 0.092 & 0.050 & 0.059 \\
\hline KT06-08 & 2 & 1 & 20 & \begin{tabular}{|l|} 
C09LM21 \\
\end{tabular} & 0.015 & 0.788 & 0.094 & 0.037 & 0.022 & 0.042 & 0.025 & 0.031 \\
\hline
\end{tabular}


Table A-1. PSAL Chemical Composition Measurements of the KT06-Series of Glasses Using LM Preparation Method (Part 1). (continued)

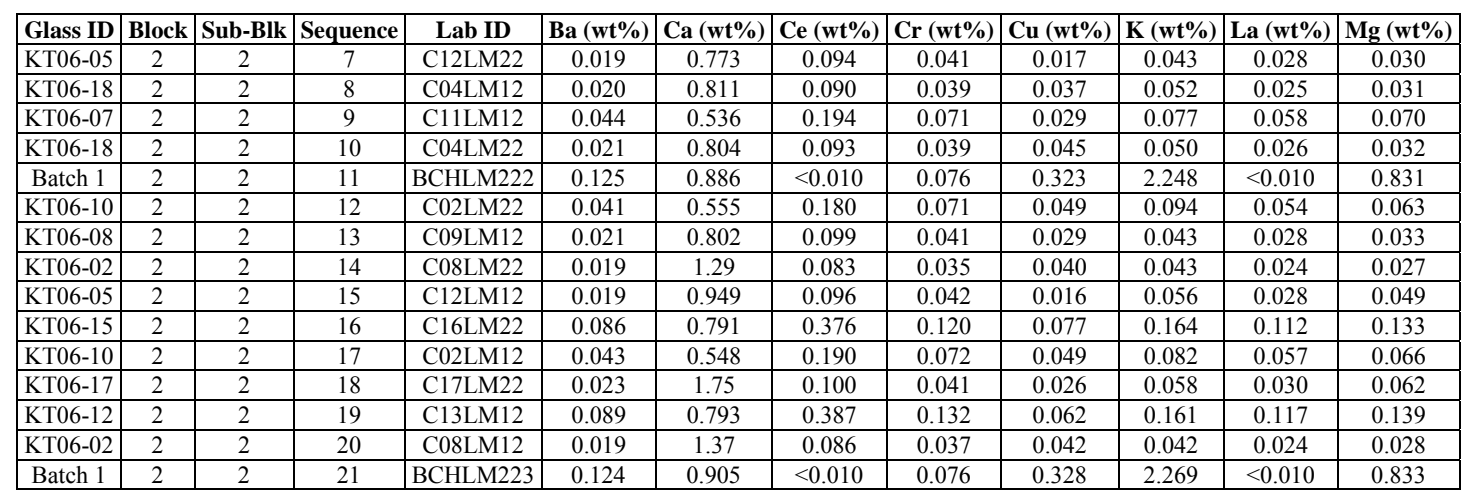


Table A-2. PSAL Chemical Composition Measurements of the KT06-Series of Glasses Using LM Preparation Method (Part 2).

\begin{tabular}{|c|c|c|c|c|c|c|c|c|c|c|c|c|c|}
\hline $\begin{array}{c}\text { Glass } \\
\text { ID }\end{array}$ & Block & $\begin{array}{l}\text { Sub- } \\
\text { Blk }\end{array}$ & Sequence & Lab ID & $\begin{array}{c}\text { Mn } \\
(w t \%)\end{array}$ & $\begin{array}{c}\mathrm{Na} \\
(\mathrm{wt} \%)\end{array}$ & $\begin{array}{c}\mathrm{Nb} \\
(\mathrm{wt} \%)\end{array}$ & $\begin{array}{c}\mathrm{Ni} \\
(\mathrm{wt} \%)\end{array}$ & $\begin{array}{c}P b \\
(w t \%)\end{array}$ & $\begin{array}{c}S \\
(w t \%)\end{array}$ & $\begin{array}{c}\mathbf{T i} \\
(w \mathbf{t} \%)\end{array}$ & $\begin{array}{c}\mathrm{Zn} \\
(\mathrm{wt} \%)\end{array}$ & $\begin{array}{c}\mathrm{Zr} \\
(\mathbf{w t} \%)\end{array}$ \\
\hline Batch 1 & 1 & 1 & 1 & \begin{tabular}{|l|} 
BCHLM111 \\
\end{tabular} & 1.29 & 6.87 & $<0.010$ & 0.555 & $<0.010$ & $<0.100$ & 0.397 & $<0.010$ & 0.063 \\
\hline KT06-16 & 1 & 1 & 2 & C03LM21 & 2.65 & 7.30 & 0.054 & 0.075 & 0.133 & $<0.100$ & 3.63 & 0.069 & 0.137 \\
\hline KT06-16 & 1 & 1 & 3 & C03LM11 & 2.62 & 7.23 & 0.054 & 0.073 & 0.127 & $<0.100$ & 3.58 & 0.060 & 0.136 \\
\hline KT06-11 & 1 & 1 & 4 & C05LM21 & 0.937 & 6.98 & 0.345 & 0.290 & 0.053 & $<0.100$ & 3.60 & 0.023 & 0.420 \\
\hline KT06-13 & 1 & 1 & 5 & C07LM11 & 2.59 & 6.95 & 0.022 & 0.076 & 0.129 & $<0.100$ & 3.52 & 0.060 & 0.089 \\
\hline KT06-01 & 1 & 1 & 6 & C15LM21 & 0.955 & 9.54 & 0.410 & 0.412 & 0.085 & $<0.100$ & 3.47 & 0.042 & 0.360 \\
\hline KT06-13 & 1 & 1 & 7 & C07LM21 & 2.59 & 6.91 & 0.018 & 0.079 & 0.134 & $<0.100$ & 3.54 & 0.059 & 0.076 \\
\hline KT06-14 & 1 & 1 & 8 & C14LM21 & 0.340 & 7.39 & 0.071 & 0.099 & 0.053 & $<0.100$ & 3.59 & 0.019 & 1.343 \\
\hline KT06-06 & 1 & 1 & 9 & C06LM21 & 0.983 & 7.61 & 0.383 & 0.346 & 0.061 & $<0.100$ & 3.66 & 0.021 & 0.460 \\
\hline KT06-11 & 1 & 1 & 10 & C05LM11 & 0.895 & 7.04 & 0.321 & 0.283 & 0.049 & $<0.100$ & 3.58 & 0.023 & 0.396 \\
\hline Batch 1 & 1 & 1 & 11 & BCHLM112 & 1.30 & 6.91 & $<0.010$ & 0.537 & $<0.010$ & $<0.100$ & 0.396 & $<0.010$ & 0.064 \\
\hline KT06-03 & 1 & 1 & 12 & \begin{tabular}{|l|} 
C10LM21 \\
\end{tabular} & 1.04 & 9.47 & 0.429 & 0.457 & 0.098 & $<0.100$ & 3.59 & 0.043 & 0.565 \\
\hline KT06-09 & 1 & 1 & 13 & C18LM21 & 0.901 & 7.96 & 0.352 & 0.283 & 0.047 & $<0.100$ & 3.57 & 0.018 & 0.421 \\
\hline KT06-01 & 1 & 1 & 14 & C15LM11 & 1.03 & 9.68 & 0.411 & 0.448 & 0.094 & $<0.100$ & 3.55 & 0.043 & 0.543 \\
\hline KT06-14 & 1 & 1 & 15 & C14LM11 & 0.349 & 7.13 & 0.069 & 0.103 & 0.056 & $<0.100$ & 3.61 & 0.019 & 1.368 \\
\hline KT06-06 & 1 & 1 & 16 & C06LM11 & 0.957 & 7.58 & 0.367 & 0.304 & 0.052 & $<0.100$ & 3.66 & 0.019 & 0.443 \\
\hline KT06-04 & 1 & 1 & 17 & C01LM21 & 0.819 & 8.61 & 0.057 & 0.807 & 0.044 & $<0.100$ & 3.62 & 0.032 & 0.140 \\
\hline KT06-09 & 1 & 1 & 18 & C18LM11 & 0.950 & 8.27 & 0.359 & 0.304 & 0.049 & $<0.100$ & 3.61 & 0.017 & 0.432 \\
\hline KT06-04 & 1 & 1 & 19 & C01LM11 & 0.834 & 8.51 & 0.057 & 0.819 & 0.046 & $<0.100$ & 3.61 & 0.031 & 0.143 \\
\hline KT06-03 & 1 & 1 & 20 & \begin{tabular}{|l|} 
C10LM11 \\
\end{tabular} & 0.939 & 9.66 & 0.380 & 0.399 & 0.081 & $<0.100$ & 3.55 & 0.043 & 0.512 \\
\hline Batch 1 & 1 & 1 & 21 & BCHLM113 & 1.27 & 6.96 & $<0.010$ & 0.539 & $<0.010$ & $<0.100$ & 0.397 & $<0.010$ & 0.065 \\
\hline Batch 1 & 1 & 2 & 1 & \begin{tabular}{|l|} 
BCHLM121 \\
\end{tabular} & 1.29 & 6.90 & $<0.010$ & 0.555 & $<0.010$ & $<0.100$ & 0.390 & $<0.010$ & 0.061 \\
\hline KT06-06 & 1 & 2 & 2 & C06LM22 & 0.997 & 7.59 & 0.383 & 0.352 & 0.059 & $<0.100$ & 3.64 & 0.020 & 0.460 \\
\hline KT06-03 & 1 & 2 & 3 & C10LM12 & 0.961 & 9.67 & 0.380 & 0.408 & 0.082 & $<0.100$ & 3.51 & 0.043 & 0.515 \\
\hline KT06-13 & 1 & 2 & 4 & C07LM22 & 2.58 & 6.98 & 0.018 & 0.079 & 0.134 & $<0.100$ & 3.50 & 0.059 & 0.074 \\
\hline KT06-01 & 1 & 2 & 5 & C15LM22 & 0.948 & 9.70 & 0.409 & 0.411 & 0.084 & $<0.100$ & 3.47 & 0.040 & 0.358 \\
\hline KT06-16 & 1 & 2 & 6 & C03LM12 & 2.61 & 7.30 & 0.053 & 0.071 & 0.124 & $<0.100$ & 3.57 & 0.058 & 0.134 \\
\hline KT06-01 & 1 & 2 & 7 & C15LM12 & 1.03 & 9.73 & 0.408 & 0.456 & 0.092 & $<0.100$ & 3.54 & 0.042 & 0.545 \\
\hline KT06-03 & 1 & 2 & 8 & C10LM22 & 1.03 & 9.61 & 0.423 & 0.465 & 0.095 & $<0.100$ & 3.61 & 0.042 & 0.566 \\
\hline KT06-11 & 1 & 2 & 9 & C05LM22 & 0.932 & 7.05 & 0.343 & 0.287 & 0.050 & $<0.100$ & 3.61 & 0.021 & 0.424 \\
\hline KT06-14 & 1 & 2 & 10 & \begin{tabular}{|l|} 
C14LM22 \\
\end{tabular} & 0.339 & 7.41 & 0.071 & 0.099 & 0.052 & $<0.100$ & 3.61 & 0.018 & 1.343 \\
\hline Batch 1 & 1 & 2 & 11 & BCHLM122 & 1.29 & 6.86 & $<0.010$ & 0.544 & $<0.010$ & $<0.100$ & 0.389 & $<0.010$ & 0.064 \\
\hline KT06-14 & 1 & 2 & 12 & C14LM12 & 0.351 & 7.16 & 0.072 & 0.103 & 0.056 & $<0.100$ & 3.59 & 0.018 & 1.382 \\
\hline KT06-06 & 1 & 2 & 13 & C06LM12 & 0.957 & 7.78 & 0.367 & 0.311 & 0.049 & $<0.100$ & 3.62 & 0.018 & 0.446 \\
\hline KT06-16 & 1 & 2 & 14 & C03LM22 & 2.63 & 7.38 & 0.053 & 0.073 & 0.129 & $<0.100$ & 3.62 & 0.066 & 0.136 \\
\hline KT06-04 & 1 & 2 & 15 & C01LM12 & 0.851 & 8.49 & 0.057 & 0.829 & 0.043 & $<0.100$ & 3.59 & 0.030 & 0.140 \\
\hline KT06-11 & 1 & 2 & 16 & C05LM12 & 0.919 & 7.06 & 0.320 & 0.287 & 0.050 & $<0.100$ & 3.61 & 0.022 & 0.395 \\
\hline KT06-13 & 1 & 2 & 17 & C07LM12 & 2.58 & 7.11 & 0.022 & 0.075 & 0.125 & $<0.100$ & 3.54 & 0.058 & 0.087 \\
\hline KT06-04 & 1 & 2 & 18 & C01LM22 & 0.838 & 8.91 & 0.056 & 0.823 & 0.042 & $<0.100$ & 3.60 & 0.031 & 0.139 \\
\hline KT06-09 & 1 & 2 & 19 & C18LM12 & 0.939 & 8.23 & 0.356 & 0.306 & 0.048 & $<0.100$ & 3.59 & 0.016 & 0.432 \\
\hline KT06-09 & 1 & 2 & 20 & C18LM22 & 0.903 & 7.97 & 0.352 & 0.283 & 0.046 & $<0.100$ & 3.56 & 0.016 & 0.420 \\
\hline Batch 1 & 1 & 2 & 21 & BCHLM123 & 1.27 & 7.06 & $<0.010$ & 0.545 & $<0.010$ & $<0.100$ & 0.388 & $<0.010$ & 0.062 \\
\hline Batch 1 & 2 & 1 & 1 & \begin{tabular}{|l|} 
BCHLM211 \\
\end{tabular} & 1.28 & 6.83 & $<0.010$ & 0.553 & $<0.010$ & $<0.100$ & 0.385 & $<0.010$ & 0.061 \\
\hline KT06-05 & 2 & 1 & 2 & C12LM21 & 0.937 & 7.37 & 0.352 & 0.295 & 0.048 & $<0.100$ & 3.46 & 0.015 & 0.426 \\
\hline KT06-18 & 2 & 1 & 3 & C04LM21 & 0.912 & 6.99 & 0.351 & 0.296 & 0.050 & $<0.100$ & 3.55 & 0.024 & 0.418 \\
\hline KT06-17 & 2 & 1 & 4 & C17LM21 & 0.324 & 7.12 & 0.022 & 0.095 & 0.050 & $<0.100$ & 3.48 & 0.018 & 1.25 \\
\hline KT06-15 & 2 & 1 & 5 & C16LM11 & 0.408 & 7.46 & 1.610 & 0.118 & 0.210 & $<0.100$ & 3.35 & 0.095 & 1.52 \\
\hline KT06-05 & 2 & 1 & 6 & C12LM11 & 0.942 & 7.60 & 0.361 & 0.293 & 0.049 & $<0.100$ & 3.59 & 0.023 & 0.448 \\
\hline KT06-02 & 2 & 1 & 7 & C08LM21 & 0.828 & 9.21 & 0.018 & 0.817 & 0.041 & $<0.100$ & 3.52 & 0.029 & 0.075 \\
\hline KT06-07 & 2 & 1 & 8 & C11LM21 & 2.71 & 7.52 & 0.059 & 0.085 & 0.102 & $<0.100$ & 3.62 & 0.039 & 1.157 \\
\hline KT06-15 & 2 & 1 & 9 & C16LM21 & 0.399 & 7.40 & 1.615 & 0.117 & 0.201 & $<0.100$ & 3.57 & 0.093 & 1.532 \\
\hline KT06-12 & 2 & 1 & 10 & \begin{tabular}{|l|} 
C13LM21 \\
\end{tabular} & 0.368 & 7.03 & 1.442 & 0.096 & 0.176 & $<0.100$ & 3.53 & 0.088 & 1.510 \\
\hline Batch 1 & 2 & 1 & 11 & BCHLM212 & 1.30 & 6.70 & $<0.010$ & 0.534 & $<0.010$ & $<0.100$ & 0.386 & $<0.010$ & 0.065 \\
\hline KT06-18 & 2 & 1 & 12 & C04LM11 & 0.870 & 6.95 & 0.337 & 0.268 & 0.045 & $<0.100$ & 3.57 & 0.024 & 0.400 \\
\hline KT06-08 & 2 & 1 & 13 & C09LM11 & 0.973 & 7.42 & 0.378 & 0.315 & 0.049 & $<0.100$ & 3.68 & 0.021 & 0.444 \\
\hline KT06-10 & 2 & 1 & 14 & C02LM11 & 2.73 & 7.85 & 0.056 & 0.078 & 0.101 & $<0.100$ & 3.65 & 0.055 & 1.098 \\
\hline KT06-17 & 2 & 1 & 15 & C17LM11 & 0.328 & 6.95 & 0.067 & 0.090 & 0.051 & $<0.100$ & 3.62 & 0.018 & 1.277 \\
\hline KT06-12 & 2 & 1 & 16 & C13LM11 & 0.415 & 6.80 & 1.649 & 0.116 & 0.205 & $<0.100$ & 3.63 & 0.089 & 1.586 \\
\hline KT06-07 & 2 & 1 & 17 & C11LM11 & 2.68 & 7.32 & 0.061 & 0.086 & 0.102 & $<0.100$ & 3.62 & 0.038 & 1.132 \\
\hline KT06-02 & 2 & 1 & 18 & C08LM11 & 0.845 & 9.36 & 0.057 & 0.824 & 0.041 & $<0.100$ & 3.56 & 0.030 & 0.144 \\
\hline KT06-10 & 2 & 1 & 19 & C02LM21 & 2.71 & 8.03 & 0.053 & 0.071 & 0.093 & $<0.100$ & 3.63 & 0.046 & 1.047 \\
\hline KT06-08 & 2 & 1 & 20 & C09LM21 & 0.979 & 7.32 & 0.374 & 0.319 & 0.050 & $<0.100$ & 3.71 & 0.023 & 0.452 \\
\hline Batch 1 & 2 & 1 & 21 & BCHLM213 & 1.32 & 6.65 & $<0.010$ & 0.543 & $<0.010$ & $<0.100$ & 0.389 & $<0.010$ & 0.063 \\
\hline Batch 1 & 2 & 2 & 1 & \begin{tabular}{|l|} 
BCHLM221 \\
\end{tabular} & 1.32 & 6.85 & $<0.010$ & 0.548 & $<0.010$ & $<0.100$ & 0.407 & $<0.010$ & 0.065 \\
\hline KT06-12 & 2 & 2 & 2 & C13LM22 & 0.372 & 7.06 & 1.435 & 0.103 & 0.183 & $<0.100$ & 3.53 & 0.091 & 1.520 \\
\hline KT06-17 & 2 & 2 & 3 & C17LM12 & 0.331 & 7.20 & 0.072 & 0.096 & 0.057 & $<0.100$ & 3.56 & 0.022 & 1.275 \\
\hline KT06-15 & 2 & 2 & 4 & C16LM12 & 0.405 & 7.60 & 1.590 & 0.121 & 0.216 & $<0.100$ & 3.39 & 0.099 & 1.520 \\
\hline
\end{tabular}


Table A-2. PSAL Chemical Composition Measurements of the KT06-Series of Glasses Using LM Preparation Method (Part 2). (continued)

\begin{tabular}{|c|c|c|c|c|c|c|c|c|c|c|c|c|c|}
\hline $\begin{array}{c}\text { Glass } \\
\text { ID }\end{array}$ & Block & $\begin{array}{l}\text { Sub- } \\
\text { Blk }\end{array}$ & Sequence & Lab ID & $\begin{array}{c}\text { Mn } \\
(w t \%)\end{array}$ & $\begin{array}{c}\mathrm{Na} \\
(\mathrm{wt} \%)\end{array}$ & $\begin{array}{c}\mathrm{Nb} \\
(\mathrm{wt} \%)\end{array}$ & $\begin{array}{c}\mathrm{Ni} \\
\text { (wt\%) }\end{array}$ & $\begin{array}{c}\text { Pb } \\
(w t \%)\end{array}$ & $\begin{array}{c}S \\
\text { (wt\%) }\end{array}$ & $\begin{array}{c}\mathbf{T i} \\
(w t \%)\end{array}$ & $\begin{array}{c}\mathrm{Zn} \\
(\mathrm{wt} \%)\end{array}$ & $\begin{array}{c}\mathrm{Zr} \\
(\mathrm{wt} \%)\end{array}$ \\
\hline KT06-08 & 2 & 2 & 5 & C09LM22 & 0.944 & 7.73 & 0.376 & 0.317 & 0.053 & $<0.100$ & 3.64 & 0.027 & 0.448 \\
\hline KT06-07 & 2 & 2 & 6 & C11LM22 & 2.68 & 7.90 & 0.065 & 0.088 & 0.106 & $<0.100$ & 3.63 & 0.043 & 1.141 \\
\hline KT06-05 & 2 & 2 & 7 & C12LM22 & 0.909 & 7.56 & 0.354 & 0.289 & 0.051 & $<0.100$ & 3.50 & 0.019 & 0.426 \\
\hline KT06-18 & 2 & 2 & 8 & C04LM12 & 0.866 & 7.35 & 0.337 & 0.275 & 0.049 & $<0.100$ & 3.58 & 0.028 & 0.406 \\
\hline KT06-07 & 2 & 2 & 9 & C11LM12 & 2.66 & 7.78 & 0.069 & 0.091 & 0.108 & $<0.100$ & 3.63 & 0.043 & 1.130 \\
\hline KT06-18 & 2 & 2 & 10 & C04LM22 & 0.899 & 7.32 & 0.353 & 0.298 & 0.054 & $<0.100$ & 3.57 & 0.028 & 0.422 \\
\hline Batch 1 & 2 & 2 & 11 & BCHLM222 & 1.32 & 6.98 & $<0.010$ & 0.548 & $<0.010$ & $<0.100$ & 0.408 & $<0.010$ & 0.067 \\
\hline KT06-10 & 2 & 2 & 12 & C02LM22 & 2.71 & 8.57 & 0.061 & 0.076 & 0.099 & $<0.100$ & 3.64 & 0.050 & 1.053 \\
\hline KT06-08 & 2 & 2 & 13 & C09LM12 & 0.959 & 8.21 & 0.384 & 0.319 & 0.056 & $<0.100$ & 3.71 & 0.026 & 0.450 \\
\hline KT06-02 & 2 & 2 & 14 & C08LM22 & 0.813 & 9.72 & 0.026 & 0.812 & 0.047 & $<0.100$ & 3.59 & 0.034 & 0.079 \\
\hline KT06-05 & 2 & 2 & 15 & C12LM12 & 0.907 & 7.87 & 0.360 & 0.287 & 0.052 & $<0.100$ & 3.69 & 0.026 & 0.447 \\
\hline KT06-15 & 2 & 2 & 16 & C16LM22 & 0.395 & 7.25 & 1.618 & 0.120 & 0.204 & $<0.100$ & 3.67 & 0.096 & 1.530 \\
\hline KT06-10 & 2 & 2 & 17 & C02LM12 & 2.77 & 8.33 & 0.063 & 0.082 & 0.107 & $<0.100$ & 3.71 & 0.059 & 1.107 \\
\hline KT06-17 & 2 & 2 & 18 & C17LM22 & 0.328 & 7.43 & 0.029 & 0.099 & 0.055 & $<0.100$ & 3.58 & 0.022 & 1.25 \\
\hline KT06-12 & 2 & 2 & 19 & C13LM12 & 0.413 & 7.16 & 1.669 & 0.119 & 0.214 & $<0.100$ & 3.65 & 0.093 & 1.587 \\
\hline KT06-02 & 2 & 2 & 20 & \begin{tabular}{|l|} 
C08LM12 \\
\end{tabular} & 0.844 & 9.78 & 0.065 & 0.835 & 0.046 & $<0.100$ & 3.60 & 0.035 & 0.151 \\
\hline Batch 1 & 2 & 2 & 21 & BCHLM223 & 1.34 & 7.10 & $<0.010$ & 0.549 & $<0.010$ & $<0.100$ & 0.411 & $<0.010$ & 0.068 \\
\hline
\end{tabular}


Table A-3. PSAL Chemical Composition Measurements of the KT06 Series of Glasses Using PF Preparation Method.

\begin{tabular}{|c|c|c|c|c|c|c|c|c|c|}
\hline Glass ID & Block & Sub-Blk & Sequence & Lab ID & $\mathrm{Al}(\mathrm{wt} \%)$ & B (wt \%) & Fe (wt \%) & Li (wt \%) & Si (wt \%) \\
\hline Batch 1 & 1 & 1 & 1 & BCHPF111 & 2.56 & 2.58 & 9.15 & 2.07 & 23.1 \\
\hline KT06-08 & 1 & 1 & 2 & C09PF11 & 3.84 & 1.63 & 7.72 & 2.50 & 23.1 \\
\hline KT06-04 & 1 & 1 & 3 & C01PF21 & 5.19 & 1.60 & 5.20 & 2.20 & 22.9 \\
\hline KT06-03 & 1 & 1 & 4 & C10PF11 & 2.94 & 1.53 & 6.43 & 2.17 & 23.1 \\
\hline KT06-02 & 1 & 1 & 5 & C08PF21 & 5.10 & 2.61 & 4.99 & 1.62 & 21.4 \\
\hline KT06-09 & 1 & 1 & 6 & C18PF21 & 2.98 & 1.55 & 8.67 & 2.51 & 22.9 \\
\hline KT06-07 & 1 & 1 & 7 & C11PF11 & 5.15 & 2.61 & 4.88 & 1.93 & 21.1 \\
\hline KT06-12 & 1 & 1 & 8 & C13PF11 & 3.41 & 2.59 & 7.19 & 2.47 & 20.5 \\
\hline KT06-02 & 1 & 1 & 9 & C08PF11 & 5.09 & 2.60 & 4.99 & 1.62 & 21.3 \\
\hline KT06-04 & 1 & 1 & 10 & C01PF11 & 5.20 & 1.54 & 5.14 & 2.21 & 22.8 \\
\hline Batch 1 & 1 & 1 & 11 & BCHPF112 & 2.56 & 2.41 & 9.02 & 2.06 & 22.9 \\
\hline KT06-16 & 1 & 1 & 12 & C03PF21 & 5.15 & 1.53 & 5.09 & 3.03 & 22.8 \\
\hline KT06-09 & 1 & 1 & 13 & C18PF11 & 2.96 & 1.52 & 8.40 & 2.50 & 22.5 \\
\hline KT06-03 & 1 & 1 & 14 & C10PF21 & 2.96 & 1.49 & 6.31 & 2.19 & 22.9 \\
\hline KT06-07 & 1 & 1 & 15 & C11PF21 & 4.94 & 2.47 & 4.76 & 1.89 & 21.4 \\
\hline KT06-12 & 1 & 1 & 16 & C13PF21 & 3.35 & 2.55 & 7.29 & 2.42 & 20.3 \\
\hline KT06-08 & 1 & 1 & 17 & C09PF21 & 3.78 & 1.49 & 7.67 & 2.46 & 22.8 \\
\hline KT06-11 & 1 & 1 & 18 & C05PF21 & 2.91 & 2.61 & 10.19 & 1.93 & 21.7 \\
\hline KT06-16 & 1 & 1 & 19 & C03PF11 & 5.18 & 1.49 & 5.12 & 3.03 & 23.0 \\
\hline KT06-11 & 1 & 1 & 20 & C05PF11 & 2.86 & 2.60 & 10.14 & 1.90 & 21.3 \\
\hline Batch 1 & 1 & 1 & 21 & BCHPF113 & 2.51 & 2.36 & 8.76 & 2.03 & 22.6 \\
\hline Batch 1 & 1 & 2 & 1 & BCHPF121 & 2.46 & 2.47 & 9.03 & 2.00 & 22.8 \\
\hline KT06-12 & 1 & 2 & 2 & C13PF12 & 3.32 & 2.62 & 7.32 & 2.42 & 20.4 \\
\hline KT06-16 & 1 & 2 & 3 & C03PF22 & 5.15 & 1.51 & 5.17 & 3.03 & 23.1 \\
\hline KT06-11 & 1 & 2 & 4 & C05PF12 & 2.85 & 2.59 & 10.23 & 1.91 & 21.7 \\
\hline KT06-09 & 1 & 2 & 5 & C18PF12 & 2.91 & 1.48 & 8.56 & 2.47 & 22.6 \\
\hline KT06-03 & 1 & 2 & 6 & C10PF12 & 2.90 & 1.45 & 6.54 & 2.15 & 23.1 \\
\hline KT06-16 & 1 & 2 & 7 & C03PF12 & 5.19 & 1.47 & 5.15 & 3.04 & 23.4 \\
\hline KT06-04 & 1 & 2 & 8 & C01PF22 & 5.12 & 1.46 & 5.17 & 2.18 & 22.8 \\
\hline KT06-09 & 1 & 2 & 9 & C18PF22 & 2.92 & 1.44 & 8.71 & 2.47 & 22.8 \\
\hline KT06-03 & 1 & 2 & 10 & C10PF22 & 2.94 & 1.40 & 6.32 & 2.18 & 23.0 \\
\hline Batch 1 & 1 & 2 & 11 & BCHPF122 & 2.54 & 2.31 & 9.04 & 2.05 & 23.0 \\
\hline KT06-02 & 1 & 2 & 12 & C08PF22 & 4.99 & 2.50 & 4.97 & 1.60 & 21.2 \\
\hline KT06-04 & 1 & 2 & 13 & C01PF12 & 5.12 & 1.45 & 5.15 & 2.18 & 22.8 \\
\hline KT06-08 & 1 & 2 & 14 & C09PF22 & 3.76 & 1.44 & 7.74 & 2.46 & 23.0 \\
\hline KT06-12 & 1 & 2 & 15 & C13PF22 & 3.31 & 2.47 & 7.24 & 2.41 & 20.3 \\
\hline KT06-07 & 1 & 2 & 16 & C11PF22 & 4.94 & 2.43 & 4.76 & 1.91 & 21.6 \\
\hline KT06-07 & 1 & 2 & 17 & C11PF12 & 5.10 & 2.52 & 4.97 & 1.92 & 21.4 \\
\hline KT06-11 & 1 & 2 & 18 & C05PF22 & 2.86 & 2.53 & 10.32 & 1.90 & 21.7 \\
\hline KT06-02 & 1 & 2 & 19 & C08PF12 & 4.99 & 2.50 & 5.04 & 1.60 & 21.3 \\
\hline KT06-08 & 1 & 2 & 20 & C09PF12 & 3.76 & 1.40 & 7.74 & 2.46 & 22.9 \\
\hline Batch 1 & 1 & 2 & 21 & BCHPF123 & 2.44 & 2.24 & 8.86 & 1.98 & 22.5 \\
\hline Batch 1 & 2 & 1 & 1 & BCHPF211 & 2.46 & 2.45 & 8.89 & 1.99 & 22.7 \\
\hline KT06-13 & 2 & 1 & 2 & C07PF11 & 5.06 & 2.67 & 5.11 & 2.43 & 22.2 \\
\hline KT06-06 & 2 & 1 & 3 & C06PF21 & 2.90 & 2.61 & 8.91 & 1.90 & 22.3 \\
\hline KT06-05 & 2 & 1 & 4 & C12PF11 & 3.80 & 2.54 & 8.00 & 1.92 & 21.2 \\
\hline KT06-15 & 2 & 1 & 5 & C16PF11 & 3.31 & 1.45 & 7.26 & 2.96 & 21.4 \\
\hline KT06-18 & 2 & 1 & 6 & C04PF21 & 2.87 & 1.48 & 10.17 & 2.16 & 23.1 \\
\hline KT06-10 & 2 & 1 & 7 & C02PF21 & 4.98 & 1.46 & 5.06 & 2.38 & 21.9 \\
\hline KT06-06 & 2 & 1 & 8 & C06PF11 & 2.88 & 2.55 & 8.90 & 1.89 & 21.9 \\
\hline KT06-17 & 2 & 1 & 9 & C17PF11 & 6.18 & 1.43 & 5.92 & 3.01 & 21.5 \\
\hline KT06-15 & 2 & 1 & 10 & C16PF21 & 3.38 & 1.41 & 7.15 & 3.01 & 21.5 \\
\hline Batch 1 & 2 & 1 & 11 & BCHPF212 & 2.50 & 2.27 & 8.75 & 2.01 & 22.7 \\
\hline KT06-10 & 2 & 1 & 12 & C02PF11 & 5.01 & 1.47 & 5.03 & 2.40 & 21.9 \\
\hline KT06-17 & 2 & 1 & 13 & C17PF21 & 6.15 & 1.44 & 5.89 & 3.00 & 21.3 \\
\hline KT06-01 & 2 & 1 & 14 & C15PF11 & 2.99 & 2.45 & 5.97 & 1.62 & 21.3 \\
\hline KT06-14 & 2 & 1 & 15 & C14PF21 & 6.15 & 2.47 & 5.67 & 2.47 & 20.1 \\
\hline KT06-13 & 2 & 1 & 16 & C07PF21 & 5.14 & 2.54 & 5.05 & 2.45 & 22.0 \\
\hline KT06-05 & 2 & 1 & 17 & C12PF21 & 3.82 & 2.57 & 7.63 & 1.92 & 21.8 \\
\hline KT06-01 & 2 & 1 & 18 & C15PF21 & 2.97 & 2.53 & 6.23 & 1.62 & 21.6 \\
\hline KT06-18 & 2 & 1 & 19 & C04PF11 & 2.92 & 1.43 & 9.95 & 2.20 & 22.8 \\
\hline KT06-14 & 2 & 1 & 20 & C14PF11 & 6.28 & 2.50 & 5.66 & 2.49 & 20.4 \\
\hline Batch 1 & 2 & 1 & 21 & BCHPF213 & 2.52 & 2.31 & 8.76 & 2.04 & 22.8 \\
\hline Batch 1 & 2 & 2 & 1 & BCHPF221 & 2.43 & 2.50 & 8.97 & 1.97 & 22.6 \\
\hline KT06-10 & 2 & 2 & 2 & C02PF12 & 5.01 & 1.61 & 5.15 & 2.40 & 22.1 \\
\hline KT06-18 & 2 & 2 & 3 & C04PF12 & 2.83 & 1.55 & 10.17 & 2.14 & 22.8 \\
\hline KT06-13 & 2 & 2 & 4 & C07PF22 & 5.02 & 2.64 & 5.23 & 2.40 & 22.2 \\
\hline KT06-15 & 2 & 2 & 5 & C16PF22 & 3.28 & 1.50 & 7.35 & 2.93 & 21.4 \\
\hline
\end{tabular}


Table A-3. PSAL Chemical Composition Measurements of the KT06 Series of Glasses Using PF Preparation Method. (continued)

\begin{tabular}{|c|c|c|c|c|c|c|c|c|c|}
\hline Glass ID & Block & Sub-Blk & Sequence & Lab ID & Al (wt\%) & B (wt \%) & Fe (wt \%) & Li (wt \%) & Si (wt \%) \\
\hline KT06-01 & 2 & 2 & 6 & C15PF12 & 2.89 & 2.56 & 6.25 & 1.58 & 21.5 \\
\hline KT06-14 & 2 & 2 & 7 & C14PF22 & 6.00 & 2.52 & 5.84 & 2.41 & 20.2 \\
\hline KT06-05 & 2 & 2 & 8 & C12PF12 & 3.80 & 2.60 & 8.19 & 1.92 & 21.5 \\
\hline KT06-17 & 2 & 2 & 9 & C17PF12 & 6.09 & 1.49 & 5.98 & 2.97 & 21.5 \\
\hline KT06-05 & 2 & 2 & 10 & C12PF22 & 3.72 & 2.60 & 7.72 & 1.88 & 21.7 \\
\hline Batch 1 & 2 & 2 & 11 & BCHPF222 & 2.44 & 2.35 & 8.85 & 1.98 & 22.6 \\
\hline KT06-06 & 2 & 2 & 12 & C06PF12 & 2.92 & 2.67 & 8.86 & 1.91 & 22.0 \\
\hline KT06-10 & 2 & 2 & 13 & C02PF22 & 5.07 & 1.56 & 5.05 & 2.43 & 22.2 \\
\hline KT06-17 & 2 & 2 & 14 & C17PF22 & 6.05 & 1.50 & 5.98 & 2.96 & 21.4 \\
\hline KT06-01 & 2 & 2 & 15 & C15PF22 & 2.95 & 2.56 & 6.16 & 1.61 & 21.6 \\
\hline KT06-13 & 2 & 2 & 16 & C07PF12 & 5.04 & 2.61 & 5.10 & 2.42 & 22.2 \\
\hline KT06-06 & 2 & 2 & 17 & C06PF22 & 2.91 & 2.65 & 8.92 & 1.94 & 22.4 \\
\hline KT06-14 & 2 & 2 & 18 & C14PF12 & 6.20 & 2.59 & 5.83 & 2.46 & 20.5 \\
\hline KT06-18 & 2 & 2 & 19 & C04PF22 & 2.90 & 1.51 & 10.04 & 2.18 & 23.0 \\
\hline KT06-15 & 2 & 2 & 20 & C16PF12 & 3.35 & 1.47 & 7.24 & 2.99 & 21.5 \\
\hline Batch 1 & 2 & 2 & 21 & BCHPF223 & 2.50 & 2.37 & 8.79 & 2.03 & 22.8 \\
\hline
\end{tabular}


Table A-4. Comparison of Measured versus Targeted Compositions for the KT06-Series Glasses.

\begin{tabular}{|c|c|c|c|c|c|}
\hline Glass ID & Oxide & $\begin{array}{l}\text { Measured } \\
(w t \%)\end{array}$ & $\begin{array}{c}\text { Targeted } \\
(\mathrm{wt} \%)\end{array}$ & $\begin{array}{c}\text { Difference of } \\
\text { Measured vs Targeted }\end{array}$ & $\begin{array}{c}\text { \% Difference of } \\
\text { Measured vs Targeted }\end{array}$ \\
\hline Batch 1 & $\mathrm{Al}_{2} \mathrm{O}_{3}$ & 4.7112 & 4.8770 & -0.1658 & $-3.4 \%$ \\
\hline Batch 1 & $\mathrm{~B}_{2} \mathrm{O}_{3}$ & 7.6795 & 7.7770 & -0.0975 & $-1.3 \%$ \\
\hline Batch 1 & $\mathrm{BaO}$ & 0.1353 & 0.1510 & -0.0157 & $-10.4 \%$ \\
\hline Batch 1 & $\mathrm{CaO}$ & 1.2248 & 1.2200 & 0.0048 & $0.4 \%$ \\
\hline Batch 1 & $\mathrm{Ce}_{2} \mathrm{O}_{3}$ & 0.0059 & 0.0000 & 0.0059 & \\
\hline Batch 1 & $\mathrm{Cr}_{2} \mathrm{O}_{3}$ & 0.1069 & 0.1070 & -0.0001 & $-0.1 \%$ \\
\hline Batch 1 & $\mathrm{CuO}$ & 0.4012 & 0.3990 & 0.0022 & $0.6 \%$ \\
\hline Batch 1 & $\mathrm{Fe}_{2} \mathrm{O}_{3}$ & 12.7327 & 12.8390 & -0.1063 & $-0.8 \%$ \\
\hline Batch 1 & $\mathrm{~K}_{2} \mathrm{O}$ & 2.6677 & 3.3270 & -0.6593 & $-19.8 \%$ \\
\hline Batch 1 & $\mathrm{La}_{2} \mathrm{O}_{3}$ & 0.0059 & 0.0000 & 0.0059 & \\
\hline Batch 1 & $\mathrm{Li}_{2} \mathrm{O}$ & 4.3435 & 4.4290 & -0.0855 & $-1.9 \%$ \\
\hline Batch 1 & $\mathrm{MgO}$ & 1.3858 & 1.4190 & -0.0332 & $-2.3 \%$ \\
\hline Batch 1 & $\mathrm{MnO}$ & 1.6775 & 1.7260 & -0.0485 & $-2.8 \%$ \\
\hline Batch 1 & $\mathrm{Na}_{2} \mathrm{O}$ & 9.2866 & 9.0030 & 0.2836 & $3.2 \%$ \\
\hline Batch 1 & $\mathrm{Nb}_{2} \mathrm{O}_{5}$ & 0.0072 & 0.0000 & 0.0072 & \\
\hline Batch 1 & $\mathrm{NiO}$ & 0.6946 & 0.7510 & -0.0564 & $-7.5 \%$ \\
\hline Batch 1 & $\mathrm{PbO}$ & 0.0054 & 0.0000 & 0.0054 & \\
\hline Batch 1 & $\mathrm{SiO}_{2}$ & 48.6869 & 50.2200 & -1.5331 & $-3.1 \%$ \\
\hline Batch 1 & $\mathrm{SO}_{4}$ & 0.1498 & 0.0000 & 0.1498 & \\
\hline Batch 1 & $\mathrm{TiO}_{2}$ & 0.6593 & 0.6770 & -0.0177 & $-2.6 \%$ \\
\hline Batch 1 & $\mathrm{ZnO}$ & 0.0062 & 0.0000 & 0.0062 & \\
\hline Batch 1 & $\mathrm{ZrO}_{2}$ & 0.0865 & 0.0980 & -0.0115 & $-11.8 \%$ \\
\hline Batch 1 & Sum & 96.6600 & 99.0200 & -2.3600 & $-2.4 \%$ \\
\hline KT06-01 & $\mathrm{Al}_{2} \mathrm{O}_{3}$ & 5.5740 & 5.4539 & 0.1201 & $2.2 \%$ \\
\hline KT06-01 & $\mathrm{B}_{2} \mathrm{O}_{3}$ & 8.1302 & 8.4000 & -0.2698 & $-3.2 \%$ \\
\hline KT06-01 & $\mathrm{BaO}$ & 0.0396 & 0.0516 & -0.0120 & $-23.2 \%$ \\
\hline KT06-01 & $\mathrm{CaO}$ & 1.2309 & 1.1959 & 0.0350 & $2.9 \%$ \\
\hline KT06-01 & $\mathrm{Ce}_{2} \mathrm{O}_{3}$ & 0.1991 & 0.2127 & -0.0136 & $-6.4 \%$ \\
\hline KT06-01 & $\mathrm{Cr}_{2} \mathrm{O}_{3}$ & 0.0950 & 0.1010 & -0.0060 & $-6.0 \%$ \\
\hline KT06-01 & $\mathrm{CuO}$ & 0.0376 & 0.0289 & 0.0086 & $29.8 \%$ \\
\hline KT06-01 & $\mathrm{Fe}_{2} \mathrm{O}_{3}$ & 8.7962 & 9.2233 & -0.4270 & $-4.6 \%$ \\
\hline KT06-01 & $\mathrm{K}_{2} \mathrm{O}$ & 0.1033 & 0.0828 & 0.0205 & $24.8 \%$ \\
\hline KT06-01 & $\mathrm{La}_{2} \mathrm{O}_{3}$ & 0.0566 & 0.0792 & -0.0226 & $-28.6 \%$ \\
\hline KT06-01 & $\mathrm{Li}_{2} \mathrm{O}$ & 3.4608 & 3.6000 & -0.1392 & $-3.9 \%$ \\
\hline KT06-01 & $\mathrm{MgO}$ & 0.0974 & 0.1148 & -0.0174 & $-15.2 \%$ \\
\hline KT06-01 & $\mathrm{MnO}$ & 1.2793 & 1.3828 & -0.1036 & $-7.5 \%$ \\
\hline KT06-01 & $\mathrm{Na}_{2} \mathrm{O}$ & 13.0251 & 13.2000 & -0.1749 & $-1.3 \%$ \\
\hline KT06-01 & $\mathrm{Nb}_{2} \mathrm{O}_{5}$ & 0.5858 & 0.6262 & -0.0404 & $-6.5 \%$ \\
\hline KT06-01 & $\mathrm{NiO}$ & 0.5494 & 0.6342 & -0.0848 & $-13.4 \%$ \\
\hline KT06-01 & $\mathrm{PbO}$ & 0.0956 & 0.1215 & -0.0259 & $-21.3 \%$ \\
\hline KT06-01 & $\mathrm{SiO}_{2}$ & 45.9950 & 48.4935 & -2.4986 & $-5.2 \%$ \\
\hline KT06-01 & $\mathrm{SO}_{4}$ & 0.1498 & 0.1780 & -0.0282 & $-15.9 \%$ \\
\hline KT06-01 & $\mathrm{TiO}_{2}$ & 5.8505 & 6.0000 & -0.1495 & $-2.5 \%$ \\
\hline KT06-01 & $\mathrm{ZnO}$ & 0.0520 & 0.0570 & -0.0050 & $-8.8 \%$ \\
\hline KT06-01 & $\mathrm{ZrO}_{2}$ & 0.6099 & 0.7624 & -0.1525 & $-20.0 \%$ \\
\hline KT06-01 & Sum & 96.0131 & 100.0000 & -3.9869 & $-4.0 \%$ \\
\hline KT06-02 & $\mathrm{Al}_{2} \mathrm{O}_{3}$ & 9.5278 & 9.4568 & 0.0710 & $0.8 \%$ \\
\hline KT06-02 & $\mathrm{B}_{2} \mathrm{O}_{3}$ & 8.2188 & 8.4000 & -0.1812 & $-2.2 \%$ \\
\hline KT06-02 & $\mathrm{BaO}$ & 0.0173 & 0.0246 & -0.0073 & $-29.8 \%$ \\
\hline KT06-02 & $\mathrm{CaO}$ & 1.8260 & 1.7411 & 0.0849 & $4.9 \%$ \\
\hline KT06-02 & $\mathrm{Ce}_{2} \mathrm{O}_{3}$ & 0.0958 & 0.1014 & -0.0056 & $-5.6 \%$ \\
\hline KT06-02 & $\mathrm{Cr}_{2} \mathrm{O}_{3}$ & 0.0497 & 0.0481 & 0.0016 & $3.4 \%$ \\
\hline KT06-02 & $\mathrm{CuO}$ & 0.0479 & 0.0137 & 0.0341 & $248.6 \%$ \\
\hline KT06-02 & $\mathrm{Fe}_{2} \mathrm{O}_{3}$ & 7.1449 & 7.2593 & -0.1143 & $-1.6 \%$ \\
\hline KT06-02 & $\mathrm{K}_{2} \mathrm{O}$ & 0.0500 & 0.0392 & 0.0108 & $27.6 \%$ \\
\hline KT06-02 & $\mathrm{La}_{2} \mathrm{O}_{3}$ & 0.0258 & 0.0376 & -0.0118 & $-31.3 \%$ \\
\hline KT06-02 & $\mathrm{Li}_{2} \mathrm{O}$ & 3.4662 & 3.6000 & -0.1338 & $-3.7 \%$ \\
\hline KT06-02 & $\mathrm{MgO}$ & 0.0419 & 0.0545 & -0.0127 & $-23.2 \%$ \\
\hline KT06-02 & $\mathrm{MnO}$ & 1.0749 & 1.1271 & -0.0521 & $-4.6 \%$ \\
\hline
\end{tabular}


Table A-4. Comparison of Measured versus Targeted Compositions for the KT06-Series Glasses. (continued)

\begin{tabular}{|c|c|c|c|c|c|}
\hline Glass ID & Oxide & $\begin{array}{c}\text { Measured } \\
(\mathrm{wt} \%)\end{array}$ & $\begin{array}{c}\text { Targeted } \\
(\mathrm{wt} \%)\end{array}$ & $\begin{array}{c}\text { Difference of } \\
\text { Measured vs Targeted }\end{array}$ & $\begin{array}{c}\text { \% Difference of } \\
\text { Measured vs Targeted }\end{array}$ \\
\hline KT06-02 & $\mathrm{Na}_{2} \mathrm{O}$ & 12.8296 & 13.2000 & -0.3704 & $-2.8 \%$ \\
\hline KT06-02 & $\mathrm{Nb}_{2} \mathrm{O}_{5}$ & 0.0594 & 0.0808 & -0.0214 & $-26.5 \%$ \\
\hline KT06-02 & $\mathrm{NiO}$ & 1.0460 & 1.1917 & -0.1457 & $-12.2 \%$ \\
\hline KT06-02 & $\mathrm{PbO}$ & 0.0471 & 0.0578 & -0.0106 & $-18.4 \%$ \\
\hline KT06-02 & $\mathrm{SiO}_{2}$ & 45.5671 & 47.1838 & -1.6167 & $-3.4 \%$ \\
\hline KT06-02 & $\mathrm{SO}_{4}$ & 0.1498 & 0.1616 & -0.0118 & $-7.3 \%$ \\
\hline KT06-02 & $\mathrm{TiO}_{2}$ & 5.9506 & 6.0000 & -0.0494 & $-0.8 \%$ \\
\hline KT06-02 & $\mathrm{ZnO}$ & 0.0398 & 0.0271 & 0.0128 & $47.2 \%$ \\
\hline KT06-02 & $\mathrm{ZrO}_{2}$ & 0.1516 & 0.1939 & -0.0423 & $-21.8 \%$ \\
\hline KT06-02 & Sum & 97.4279 & 100.0000 & -2.5721 & $-2.6 \%$ \\
\hline KT06-03 & $\mathrm{Al}_{2} \mathrm{O}_{3}$ & 5.5457 & 5.4539 & 0.0917 & $1.7 \%$ \\
\hline KT06-03 & $\mathrm{B}_{2} \mathrm{O}_{3}$ & 4.7252 & 4.8000 & -0.0748 & $-1.6 \%$ \\
\hline KT06-03 & $\mathrm{BaO}$ & 0.0416 & 0.0516 & -0.0100 & $-19.4 \%$ \\
\hline KT06-03 & $\mathrm{CaO}$ & 1.2358 & 1.1959 & 0.0399 & $3.3 \%$ \\
\hline KT06-03 & $\mathrm{Ce}_{2} \mathrm{O}_{3}$ & 0.2018 & 0.2127 & -0.0110 & $-5.2 \%$ \\
\hline KT06-03 & $\mathrm{Cr}_{2} \mathrm{O}_{3}$ & 0.0972 & 0.1010 & -0.0038 & $-3.8 \%$ \\
\hline KT06-03 & $\mathrm{CuO}$ & 0.0401 & 0.0289 & 0.0111 & $38.5 \%$ \\
\hline KT06-03 & $\mathrm{Fe}_{2} \mathrm{O}_{3}$ & 9.1501 & 9.2233 & -0.0732 & $-0.8 \%$ \\
\hline KT06-03 & $\mathrm{K}_{2} \mathrm{O}$ & 0.1030 & 0.0828 & 0.0202 & $24.4 \%$ \\
\hline KT06-03 & $\mathrm{La}_{2} \mathrm{O}_{3}$ & 0.0557 & 0.0792 & -0.0235 & $-29.7 \%$ \\
\hline KT06-03 & $\mathrm{Li}_{2} \mathrm{O}$ & 4.6772 & 4.8000 & -0.1228 & $-2.6 \%$ \\
\hline KT06-03 & $\mathrm{MgO}$ & 0.1007 & 0.1148 & -0.0141 & $-12.3 \%$ \\
\hline KT06-03 & $\mathrm{MnO}$ & 1.2815 & 1.3828 & -0.1013 & $-7.3 \%$ \\
\hline KT06-03 & $\mathrm{Na}_{2} \mathrm{O}$ & 12.9442 & 13.2000 & -0.2558 & $-1.9 \%$ \\
\hline KT06-03 & $\mathrm{Nb}_{2} \mathrm{O}_{5}$ & 0.5765 & 0.6262 & -0.0497 & $-7.9 \%$ \\
\hline KT06-03 & $\mathrm{NiO}$ & 0.5500 & 0.6342 & -0.0842 & $-13.3 \%$ \\
\hline KT06-03 & $\mathrm{PbO}$ & 0.0959 & 0.1215 & -0.0256 & $-21.1 \%$ \\
\hline KT06-03 & $\mathrm{SiO}_{2}$ & 49.2574 & 50.8935 & -1.6361 & $-3.2 \%$ \\
\hline KT06-03 & $\mathrm{SO}_{4}$ & 0.1498 & 0.1780 & -0.0282 & $-15.9 \%$ \\
\hline KT06-03 & $\mathrm{TiO}_{2}$ & 5.9464 & 6.0000 & -0.0536 & $-0.9 \%$ \\
\hline KT06-03 & $\mathrm{ZnO}$ & 0.0532 & 0.0570 & -0.0038 & $-6.6 \%$ \\
\hline KT06-03 & $\mathrm{ZrO}_{2}$ & 0.7288 & 0.7624 & -0.0337 & $-4.4 \%$ \\
\hline KT06-03 & Sum & 97.5577 & 100.0000 & -2.4423 & $-2.4 \%$ \\
\hline KT06-04 & $\mathrm{Al}_{2} \mathrm{O}_{3}$ & 9.7451 & 9.4568 & 0.2882 & $3.0 \%$ \\
\hline KT06-04 & $\mathrm{B}_{2} \mathrm{O}_{3}$ & 4.8701 & 4.8000 & 0.0701 & $1.5 \%$ \\
\hline KT06-04 & $\mathrm{BaO}$ & 0.0154 & 0.0246 & -0.0093 & $-37.7 \%$ \\
\hline KT06-04 & $\mathrm{CaO}$ & 1.8469 & 1.7411 & 0.1058 & $6.1 \%$ \\
\hline KT06-04 & $\mathrm{Ce}_{2} \mathrm{O}_{3}$ & 0.0928 & 0.1014 & -0.0086 & $-8.5 \%$ \\
\hline KT06-04 & $\mathrm{Cr}_{2} \mathrm{O}_{3}$ & 0.0504 & 0.0481 & 0.0024 & $4.9 \%$ \\
\hline KT06-04 & $\mathrm{CuO}$ & 0.0407 & 0.0137 & 0.0269 & $196.2 \%$ \\
\hline KT06-04 & $\mathrm{Fe}_{2} \mathrm{O}_{3}$ & 7.3844 & 7.2593 & 0.1251 & $1.7 \%$ \\
\hline KT06-04 & $\mathrm{K}_{2} \mathrm{O}$ & 0.0530 & 0.0392 & 0.0138 & $35.3 \%$ \\
\hline KT06-04 & $\mathrm{La}_{2} \mathrm{O}_{3}$ & 0.0240 & 0.0376 & -0.0135 & $-36.0 \%$ \\
\hline KT06-04 & $\mathrm{Li}_{2} \mathrm{O}$ & 4.7202 & 4.8000 & -0.0798 & $-1.7 \%$ \\
\hline KT06-04 & $\mathrm{MgO}$ & 0.0410 & 0.0545 & -0.0135 & $-24.7 \%$ \\
\hline KT06-04 & $\mathrm{MnO}$ & 1.0788 & 1.1271 & -0.0483 & $-4.3 \%$ \\
\hline KT06-04 & $\mathrm{Na}_{2} \mathrm{O}$ & 11.6332 & 13.2000 & -1.5668 & $-11.9 \%$ \\
\hline KT06-04 & $\mathrm{Nb}_{2} \mathrm{O}_{5}$ & 0.0812 & 0.0808 & 0.0004 & $0.5 \%$ \\
\hline KT06-04 & $\mathrm{NiO}$ & 1.0428 & 1.1917 & -0.1489 & $-12.5 \%$ \\
\hline KT06-04 & $\mathrm{PbO}$ & 0.0471 & 0.0578 & -0.0106 & $-18.4 \%$ \\
\hline KT06-04 & $\mathrm{SiO}_{2}$ & 48.8295 & 49.5838 & -0.7542 & $-1.5 \%$ \\
\hline KT06-04 & $\mathrm{SO}_{4}$ & 0.1498 & 0.1616 & -0.0118 & $-7.3 \%$ \\
\hline KT06-04 & $\mathrm{TiO}_{2}$ & 6.0131 & 6.0000 & 0.0131 & $0.2 \%$ \\
\hline KT06-04 & $\mathrm{ZnO}$ & 0.0386 & 0.0271 & 0.0115 & $42.6 \%$ \\
\hline KT06-04 & $\mathrm{ZrO}_{2}$ & 0.1898 & 0.1939 & -0.0041 & $-2.1 \%$ \\
\hline KT06-04 & Sum & 97.9881 & 100.0000 & -2.0119 & $-2.0 \%$ \\
\hline KT06-05 & $\mathrm{Al}_{2} \mathrm{O}_{3}$ & 7.1518 & 6.9766 & 0.1752 & $2.5 \%$ \\
\hline KT06-05 & $\mathrm{B}_{2} \mathrm{O}_{3}$ & 8.2993 & 8.4000 & -0.1007 & $-1.2 \%$ \\
\hline
\end{tabular}


Table A-4. Comparison of Measured versus Targeted Compositions for the KT06-Series Glasses. (continued)

\begin{tabular}{|c|c|c|c|c|c|}
\hline Glass ID & Oxide & $\begin{array}{c}\text { Measured } \\
\text { (wt\%) }\end{array}$ & $\begin{array}{c}\text { Targeted } \\
(\mathrm{wt} \%)\end{array}$ & $\begin{array}{c}\text { Difference of } \\
\text { Measured vs Targeted }\end{array}$ & $\begin{array}{c}\text { \% Difference of } \\
\text { Measured vs Targeted }\end{array}$ \\
\hline KT06-05 & $\mathrm{BaO}$ & 0.0179 & 0.0274 & -0.0095 & $-34.8 \%$ \\
\hline KT06-05 & $\mathrm{CaO}$ & 1.1837 & 1.0766 & 0.1072 & $10.0 \%$ \\
\hline KT06-05 & $\mathrm{Ce}_{2} \mathrm{O}_{3}$ & 0.1086 & 0.1127 & -0.0040 & $-3.6 \%$ \\
\hline KT06-05 & $\mathrm{Cr}_{2} \mathrm{O}_{3}$ & 0.0588 & 0.0534 & 0.0054 & $10.1 \%$ \\
\hline KT06-05 & $\mathrm{CuO}$ & 0.0175 & 0.0153 & 0.0023 & $14.8 \%$ \\
\hline KT06-05 & $\mathrm{Fe}_{2} \mathrm{O}_{3}$ & 11.2732 & 10.8972 & 0.3760 & $3.5 \%$ \\
\hline KT06-05 & $\mathrm{K}_{2} \mathrm{O}$ & 0.0581 & 0.0435 & 0.0146 & $33.5 \%$ \\
\hline KT06-05 & $\mathrm{La}_{2} \mathrm{O}_{3}$ & 0.0308 & 0.0418 & -0.0110 & $-26.3 \%$ \\
\hline KT06-05 & $\mathrm{Li}_{2} \mathrm{O}$ & 4.1120 & 4.2000 & -0.0880 & $-2.1 \%$ \\
\hline KT06-05 & $\mathrm{MgO}$ & 0.0643 & 0.0606 & 0.0037 & $6.0 \%$ \\
\hline KT06-05 & $\mathrm{MnO}$ & 1.1927 & 1.2494 & -0.0567 & $-4.5 \%$ \\
\hline KT06-05 & $\mathrm{Na}_{2} \mathrm{O}$ & 10.2448 & 11.2000 & -0.9552 & $-8.5 \%$ \\
\hline KT06-05 & $\mathrm{Nb}_{2} \mathrm{O}_{5}$ & 0.5103 & 0.5450 & -0.0347 & $-6.4 \%$ \\
\hline KT06-05 & $\mathrm{NiO}$ & 0.3703 & 0.4287 & -0.0584 & $-13.6 \%$ \\
\hline KT06-05 & $\mathrm{PbO}$ & 0.0539 & 0.0642 & -0.0103 & $-16.1 \%$ \\
\hline KT06-05 & $\mathrm{SiO}_{2}$ & 46.1019 & 47.8018 & -1.6999 & $-3.6 \%$ \\
\hline KT06-05 & $\mathrm{SO}_{4}$ & 0.1498 & 0.1796 & -0.0298 & $-16.6 \%$ \\
\hline KT06-05 & $\mathrm{TiO}_{2}$ & 5.9381 & 6.0000 & -0.0619 & $-1.0 \%$ \\
\hline KT06-05 & $\mathrm{ZnO}$ & 0.0258 & 0.0301 & -0.0042 & $-14.1 \%$ \\
\hline KT06-05 & $\mathrm{ZrO}_{2}$ & 0.5900 & 0.5962 & -0.0062 & $-1.0 \%$ \\
\hline KT06-05 & Sum & 97.5536 & 100.0000 & -2.4464 & $-2.4 \%$ \\
\hline KT06-06 & $\mathrm{Al}_{2} \mathrm{O}_{3}$ & 5.4843 & 5.3819 & 0.1024 & $1.9 \%$ \\
\hline KT06-06 & $\mathrm{B}_{2} \mathrm{O}_{3}$ & 8.4361 & 8.4000 & 0.0361 & $0.4 \%$ \\
\hline KT06-06 & $\mathrm{BaO}$ & 0.0201 & 0.0274 & -0.0073 & $-26.6 \%$ \\
\hline KT06-06 & $\mathrm{CaO}$ & 1.1078 & 1.0766 & 0.0313 & $2.9 \%$ \\
\hline KT06-06 & $\mathrm{Ce}_{2} \mathrm{O}_{3}$ & 0.1122 & 0.1127 & -0.0005 & $-0.5 \%$ \\
\hline KT06-06 & $\mathrm{Cr}_{2} \mathrm{O}_{3}$ & 0.0566 & 0.0534 & 0.0032 & $6.0 \%$ \\
\hline KT06-06 & $\mathrm{CuO}$ & 0.0319 & 0.0153 & 0.0167 & $109.1 \%$ \\
\hline KT06-06 & $\mathrm{Fe}_{2} \mathrm{O}_{3}$ & 12.7208 & 12.4918 & 0.2289 & $1.8 \%$ \\
\hline KT06-06 & $\mathrm{K}_{2} \mathrm{O}$ & 0.0521 & 0.0435 & 0.0086 & $19.6 \%$ \\
\hline KT06-06 & $\mathrm{La}_{2} \mathrm{O}_{3}$ & 0.0287 & 0.0418 & -0.0130 & $-31.2 \%$ \\
\hline KT06-06 & $\mathrm{Li}_{2} \mathrm{O}$ & 4.1120 & 4.2000 & -0.0880 & $-2.1 \%$ \\
\hline KT06-06 & $\mathrm{MgO}$ & 0.0510 & 0.0606 & -0.0096 & $-15.9 \%$ \\
\hline KT06-06 & $\mathrm{MnO}$ & 1.2570 & 1.2494 & 0.0076 & $0.6 \%$ \\
\hline KT06-06 & $\mathrm{Na}_{2} \mathrm{O}$ & 10.2987 & 11.2000 & -0.9013 & $-8.0 \%$ \\
\hline KT06-06 & $\mathrm{Nb}_{2} \mathrm{O}_{5}$ & 0.5364 & 0.5450 & -0.0086 & $-1.6 \%$ \\
\hline KT06-06 & $\mathrm{NiO}$ & 0.4177 & 0.4287 & -0.0110 & $-2.6 \%$ \\
\hline KT06-06 & $\mathrm{PbO}$ & 0.0595 & 0.0642 & -0.0047 & $-7.3 \%$ \\
\hline KT06-06 & $\mathrm{SiO}_{2}$ & 47.3855 & 47.8018 & -0.4163 & $-0.9 \%$ \\
\hline KT06-06 & $\mathrm{SO}_{4}$ & 0.1498 & 0.1796 & -0.0298 & $-16.6 \%$ \\
\hline KT06-06 & $\mathrm{TiO}_{2}$ & 6.0799 & 6.0000 & 0.0799 & $1.3 \%$ \\
\hline KT06-06 & $\mathrm{ZnO}$ & 0.0243 & 0.0301 & -0.0058 & $-19.3 \%$ \\
\hline KT06-06 & $\mathrm{ZrO}_{2}$ & 0.6109 & 0.5962 & 0.0147 & $2.5 \%$ \\
\hline KT06-06 & Sum & 99.0333 & 100.0000 & -0.9667 & $-1.0 \%$ \\
\hline KT06-07 & $\mathrm{Al}_{2} \mathrm{O}_{3}$ & 9.5089 & 9.4490 & 0.0599 & $0.6 \%$ \\
\hline KT06-07 & $\mathrm{B}_{2} \mathrm{O}_{3}$ & 8.0739 & 8.4000 & -0.3261 & $-3.9 \%$ \\
\hline KT06-07 & $\mathrm{BaO}$ & 0.0458 & 0.0533 & -0.0075 & $-14.1 \%$ \\
\hline KT06-07 & $\mathrm{CaO}$ & 0.7433 & 0.7104 & 0.0329 & $4.6 \%$ \\
\hline KT06-07 & $\mathrm{Ce}_{2} \mathrm{O}_{3}$ & 0.2252 & 0.2204 & 0.0048 & $2.2 \%$ \\
\hline KT06-07 & $\mathrm{Cr}_{2} \mathrm{O}_{3}$ & 0.1016 & 0.1049 & -0.0034 & $-3.2 \%$ \\
\hline KT06-07 & $\mathrm{CuO}$ & 0.0344 & 0.0299 & 0.0046 & $15.3 \%$ \\
\hline KT06-07 & $\mathrm{Fe}_{2} \mathrm{O}_{3}$ & 6.9233 & 7.2533 & -0.3300 & $-4.5 \%$ \\
\hline KT06-07 & $\mathrm{K}_{2} \mathrm{O}$ & 0.0909 & 0.0856 & 0.0054 & $6.3 \%$ \\
\hline KT06-07 & $\mathrm{La}_{2} \mathrm{O}_{3}$ & 0.0654 & 0.0819 & -0.0166 & $-20.2 \%$ \\
\hline KT06-07 & $\mathrm{Li}_{2} \mathrm{O}$ & 4.1174 & 4.2000 & -0.0826 & $-2.0 \%$ \\
\hline KT06-07 & $\mathrm{MgO}$ & 0.1132 & 0.1191 & -0.0059 & $-4.9 \%$ \\
\hline KT06-07 & $\mathrm{MnO}$ & 3.4636 & 3.4026 & 0.0610 & $1.8 \%$ \\
\hline KT06-07 & $\mathrm{Na}_{2} \mathrm{O}$ & 10.2852 & 11.2000 & -0.9148 & $-8.2 \%$ \\
\hline
\end{tabular}


Table A-4. Comparison of Measured versus Targeted Compositions for the KT06-Series Glasses. (continued)

\begin{tabular}{|c|c|c|c|c|c|}
\hline Glass ID & Oxide & $\begin{array}{c}\text { Measured } \\
\text { (wt\%) }\end{array}$ & $\begin{array}{c}\text { Targeted } \\
(\mathrm{wt} \%)\end{array}$ & $\begin{array}{c}\text { Difference of } \\
\text { Measured vs Targeted }\end{array}$ & $\begin{array}{c}\text { \% Difference of } \\
\text { Measured vs Targeted }\end{array}$ \\
\hline KT06-07 & $\mathrm{Nb}_{2} \mathrm{O}_{5}$ & 0.0908 & 0.0807 & 0.0101 & $12.5 \%$ \\
\hline KT06-07 & $\mathrm{NiO}$ & 0.1113 & 0.1171 & -0.0057 & $-4.9 \%$ \\
\hline KT06-07 & $\mathrm{PbO}$ & 0.1126 & 0.1255 & -0.0130 & $-10.3 \%$ \\
\hline KT06-07 & $\mathrm{SiO}_{2}$ & 45.7275 & 46.5835 & -0.8559 & $-1.8 \%$ \\
\hline KT06-07 & $\mathrm{SO}_{4}$ & 0.1498 & 0.1615 & -0.0117 & $-7.2 \%$ \\
\hline KT06-07 & $\mathrm{TiO}_{2}$ & 6.0465 & 6.0000 & 0.0465 & $0.8 \%$ \\
\hline KT06-07 & $\mathrm{ZnO}$ & 0.0507 & 0.0593 & -0.0086 & $-14.5 \%$ \\
\hline KT06-07 & $\mathrm{ZrO}_{2}$ & 1.5399 & 1.5621 & -0.0221 & $-1.4 \%$ \\
\hline KT06-07 & Sum & 97.6215 & 100.0000 & -2.3785 & $-2.4 \%$ \\
\hline KT06-08 & $\mathrm{Al}_{2} \mathrm{O}_{3}$ & 7.1518 & 6.9766 & 0.1752 & $2.5 \%$ \\
\hline KT06-08 & $\mathrm{B}_{2} \mathrm{O}_{3}$ & 4.7977 & 4.8000 & -0.0023 & $0.0 \%$ \\
\hline KT06-08 & $\mathrm{BaO}$ & 0.0198 & 0.0274 & -0.0076 & $-27.6 \%$ \\
\hline KT06-08 & $\mathrm{CaO}$ & 1.1075 & 1.0766 & 0.0309 & $2.9 \%$ \\
\hline KT06-08 & $\mathrm{Ce}_{2} \mathrm{O}_{3}$ & 0.1127 & 0.1127 & 0.0001 & $0.0 \%$ \\
\hline KT06-08 & $\mathrm{Cr}_{2} \mathrm{O}_{3}$ & 0.0563 & 0.0534 & 0.0028 & $5.3 \%$ \\
\hline KT06-08 & $\mathrm{CuO}$ & 0.0316 & 0.0153 & 0.0163 & $107.1 \%$ \\
\hline KT06-08 & $\mathrm{Fe}_{2} \mathrm{O}_{3}$ & 11.0337 & 10.8972 & 0.1365 & $1.3 \%$ \\
\hline KT06-08 & $\mathrm{K}_{2} \mathrm{O}$ & 0.0512 & 0.0435 & 0.0076 & $17.6 \%$ \\
\hline KT06-08 & $\mathrm{La}_{2} \mathrm{O}_{3}$ & 0.0311 & 0.0418 & -0.0107 & $-25.6 \%$ \\
\hline KT06-08 & $\mathrm{Li}_{2} \mathrm{O}$ & 5.3177 & 5.4000 & -0.0823 & $-1.5 \%$ \\
\hline KT06-08 & $\mathrm{MgO}$ & 0.0527 & 0.0606 & -0.0080 & $-13.1 \%$ \\
\hline KT06-08 & $\mathrm{MnO}$ & 1.2444 & 1.2494 & -0.0050 & $-0.4 \%$ \\
\hline KT06-08 & $\mathrm{Na}_{2} \mathrm{O}$ & 10.3392 & 11.2000 & -0.8608 & $-7.7 \%$ \\
\hline KT06-08 & $\mathrm{Nb}_{2} \mathrm{O}_{5}$ & 0.5407 & 0.5450 & -0.0043 & $-0.8 \%$ \\
\hline KT06-08 & $\mathrm{NiO}$ & 0.4040 & 0.4287 & -0.0247 & $-5.8 \%$ \\
\hline KT06-08 & $\mathrm{PbO}$ & 0.0560 & 0.0642 & -0.0082 & $-12.7 \%$ \\
\hline KT06-08 & $\mathrm{SiO}_{2}$ & 49.0969 & 50.2018 & -1.1049 & $-2.2 \%$ \\
\hline KT06-08 & $\mathrm{SO}_{4}$ & 0.1498 & 0.1796 & -0.0298 & $-16.6 \%$ \\
\hline KT06-08 & $\mathrm{TiO}_{2}$ & 6.1466 & 6.0000 & 0.1466 & $2.4 \%$ \\
\hline KT06-08 & $\mathrm{ZnO}$ & 0.0302 & 0.0301 & 0.0001 & $0.4 \%$ \\
\hline KT06-08 & $\mathrm{ZrO}_{2}$ & 0.6058 & 0.5962 & 0.0096 & $1.6 \%$ \\
\hline KT06-08 & Sum & 98.3773 & 100.0000 & -1.6227 & $-1.6 \%$ \\
\hline KT06-09 & $\mathrm{Al}_{2} \mathrm{O}_{3}$ & 5.5599 & 5.3819 & 0.1779 & $3.3 \%$ \\
\hline KT06-09 & $\mathrm{B}_{2} \mathrm{O}_{3}$ & 4.8218 & 4.8000 & 0.0218 & $0.5 \%$ \\
\hline KT06-09 & $\mathrm{BaO}$ & 0.0187 & 0.0274 & -0.0087 & $-31.7 \%$ \\
\hline KT06-09 & $\mathrm{CaO}$ & 1.1152 & 1.0766 & 0.0386 & $3.6 \%$ \\
\hline KT06-09 & $\mathrm{Ce}_{2} \mathrm{O}_{3}$ & 0.1054 & 0.1127 & -0.0073 & $-6.4 \%$ \\
\hline KT06-09 & $\mathrm{Cr}_{2} \mathrm{O}_{3}$ & 0.0523 & 0.0534 & -0.0012 & $-2.2 \%$ \\
\hline KT06-09 & $\mathrm{CuO}$ & 0.0175 & 0.0153 & 0.0023 & $14.8 \%$ \\
\hline KT06-09 & $\mathrm{Fe}_{2} \mathrm{O}_{3}$ & 12.2740 & 12.4918 & -0.2178 & $-1.7 \%$ \\
\hline КТ06-09 & $\mathrm{K}_{2} \mathrm{O}$ & 0.0554 & 0.0435 & 0.0119 & $27.2 \%$ \\
\hline KT06-09 & $\mathrm{La}_{2} \mathrm{O}_{3}$ & 0.0276 & 0.0418 & -0.0142 & $-34.0 \%$ \\
\hline KT06-09 & $\mathrm{Li}_{2} \mathrm{O}$ & 5.3553 & 5.4000 & -0.0447 & $-0.8 \%$ \\
\hline KT06-09 & $\mathrm{MgO}$ & 0.0460 & 0.0606 & -0.0146 & $-24.1 \%$ \\
\hline KT06-09 & $\mathrm{MnO}$ & 1.1921 & 1.2494 & -0.0573 & $-4.6 \%$ \\
\hline KT06-09 & $\mathrm{Na}_{2} \mathrm{O}$ & 10.9289 & 11.2000 & -0.2711 & $-2.4 \%$ \\
\hline KT06-09 & $\mathrm{Nb}_{2} \mathrm{O}_{5}$ & 0.5075 & 0.5450 & -0.0375 & $-6.9 \%$ \\
\hline KT06-09 & $\mathrm{NiO}$ & 0.3741 & 0.4287 & -0.0546 & $-12.7 \%$ \\
\hline KT06-09 & $\mathrm{PbO}$ & 0.0512 & 0.0642 & -0.0130 & $-20.3 \%$ \\
\hline KT06-09 & $\mathrm{SiO}_{2}$ & 48.5621 & 50.2018 & -1.6397 & $-3.3 \%$ \\
\hline KT06-09 & $\mathrm{SO}_{4}$ & 0.1498 & 0.1796 & -0.0298 & $-16.6 \%$ \\
\hline KT06-09 & $\mathrm{TiO}_{2}$ & 5.9756 & 6.0000 & -0.0244 & $-0.4 \%$ \\
\hline KT06-09 & $\mathrm{ZnO}$ & 0.0209 & 0.0301 & -0.0092 & $-30.7 \%$ \\
\hline KT06-09 & $\mathrm{ZrO}_{2}$ & 0.5758 & 0.5962 & -0.0204 & $-3.4 \%$ \\
\hline KT06-09 & Sum & 97.7869 & 100.0000 & -2.2131 & $-2.2 \%$ \\
\hline KT06-10 & $\mathrm{Al}_{2} \mathrm{O}_{3}$ & 9.4806 & 9.4490 & 0.0315 & $0.3 \%$ \\
\hline KT06-10 & $\mathrm{B}_{2} \mathrm{O}_{3}$ & 4.9103 & 4.8000 & 0.1103 & $2.3 \%$ \\
\hline KT06-10 & $\mathrm{BaO}$ & 0.0435 & 0.0533 & -0.0097 & $-18.3 \%$ \\
\hline
\end{tabular}


Table A-4. Comparison of Measured versus Targeted Compositions for the KT06-Series Glasses. (continued)

\begin{tabular}{|c|c|c|c|c|c|}
\hline Glass ID & Oxide & $\begin{array}{c}\text { Measured } \\
\text { (wt\%) }\end{array}$ & $\begin{array}{c}\text { Targeted } \\
(\mathrm{wt} \%)\end{array}$ & $\begin{array}{c}\text { Difference of } \\
\text { Measured vs Targeted }\end{array}$ & $\begin{array}{c}\text { \% Difference of } \\
\text { Measured vs Targeted }\end{array}$ \\
\hline KT06-10 & $\mathrm{CaO}$ & 0.7629 & 0.7104 & 0.0525 & $7.4 \%$ \\
\hline KT06-10 & $\mathrm{Ce}_{2} \mathrm{O}_{3}$ & 0.2129 & 0.2204 & -0.0075 & $-3.4 \%$ \\
\hline KT06-10 & $\mathrm{Cr}_{2} \mathrm{O}_{3}$ & 0.1019 & 0.1049 & -0.0030 & $-2.9 \%$ \\
\hline KT06-10 & $\mathrm{CuO}$ & 0.0582 & 0.0299 & 0.0283 & $94.9 \%$ \\
\hline KT06-10 & $\mathrm{Fe}_{2} \mathrm{O}_{3}$ & 7.2522 & 7.2533 & -0.0011 & $0.0 \%$ \\
\hline KT06-10 & $\mathrm{K}_{2} \mathrm{O}$ & 0.1045 & 0.0856 & 0.0189 & $22.1 \%$ \\
\hline KT06-10 & $\mathrm{La}_{2} \mathrm{O}_{3}$ & 0.0625 & 0.0819 & -0.0195 & $-23.8 \%$ \\
\hline KT06-10 & $\mathrm{Li}_{2} \mathrm{O}$ & 5.1723 & 5.4000 & -0.2277 & $-4.2 \%$ \\
\hline KT06-10 & $\mathrm{MgO}$ & 0.1041 & 0.1191 & -0.0150 & $-12.6 \%$ \\
\hline KT06-10 & $\mathrm{MnO}$ & 3.5250 & 3.4026 & 0.1224 & $3.6 \%$ \\
\hline KT06-10 & $\mathrm{Na}_{2} \mathrm{O}$ & 11.0469 & 11.2000 & -0.1531 & $-1.4 \%$ \\
\hline KT06-10 & $\mathrm{Nb}_{2} \mathrm{O}_{5}$ & 0.0833 & 0.0807 & 0.0026 & $3.2 \%$ \\
\hline KT06-10 & $\mathrm{NiO}$ & 0.0977 & 0.1171 & -0.0194 & $-16.6 \%$ \\
\hline KT06-10 & $\mathrm{PbO}$ & 0.1077 & 0.1255 & -0.0178 & $-14.2 \%$ \\
\hline KT06-10 & $\mathrm{SiO}_{2}$ & 47.1181 & 48.9835 & -1.8654 & $-3.8 \%$ \\
\hline KT06-10 & $\mathrm{SO}_{4}$ & 0.1498 & 0.1615 & -0.0117 & $-7.2 \%$ \\
\hline KT06-10 & $\mathrm{TiO}_{2}$ & 6.1007 & 6.0000 & 0.1007 & $1.7 \%$ \\
\hline KT06-10 & $\mathrm{ZnO}$ & 0.0654 & 0.0593 & 0.0060 & $10.1 \%$ \\
\hline KT06-10 & $\mathrm{ZrO}_{2}$ & 1.4538 & 1.5621 & -0.1083 & $-6.9 \%$ \\
\hline KT06-10 & Sum & 98.0142 & 100.0000 & -1.9858 & $-2.0 \%$ \\
\hline KT06-11 & $\mathrm{Al}_{2} \mathrm{O}_{3}$ & 5.4229 & 5.3317 & 0.0911 & $1.7 \%$ \\
\hline KT06-11 & $\mathrm{B}_{2} \mathrm{O}_{3}$ & 8.3154 & 8.4000 & -0.0846 & $-1.0 \%$ \\
\hline KT06-11 & $\mathrm{BaO}$ & 0.0195 & 0.0271 & -0.0076 & $-28.0 \%$ \\
\hline KT06-11 & $\mathrm{CaO}$ & 1.1015 & 1.0665 & 0.0350 & $3.3 \%$ \\
\hline KT06-11 & $\mathrm{Ce}_{2} \mathrm{O}_{3}$ & 0.1045 & 0.1116 & -0.0071 & $-6.4 \%$ \\
\hline KT06-11 & $\mathrm{Cr}_{2} \mathrm{O}_{3}$ & 0.0512 & 0.0529 & -0.0018 & $-3.3 \%$ \\
\hline KT06-11 & $\mathrm{CuO}$ & 0.0407 & 0.0151 & 0.0256 & $169.0 \%$ \\
\hline KT06-11 & $\mathrm{Fe}_{2} \mathrm{O}_{3}$ & 14.6115 & 14.5991 & 0.0124 & $0.1 \%$ \\
\hline KT06-11 & $\mathrm{K}_{2} \mathrm{O}$ & 0.0554 & 0.0431 & 0.0123 & $28.4 \%$ \\
\hline KT06-11 & $\mathrm{La}_{2} \mathrm{O}_{3}$ & 0.0261 & 0.0414 & -0.0153 & $-36.9 \%$ \\
\hline KT06-11 & $\mathrm{Li}_{2} \mathrm{O}$ & 4.1120 & 4.2000 & -0.0880 & $-2.1 \%$ \\
\hline KT06-11 & $\mathrm{MgO}$ & 0.0460 & 0.0600 & -0.0140 & $-23.4 \%$ \\
\hline KT06-11 & $\mathrm{MnO}$ & 1.1889 & 1.2378 & -0.0489 & $-3.9 \%$ \\
\hline KT06-11 & $\mathrm{Na}_{2} \mathrm{O}$ & 9.4798 & 9.2000 & 0.2798 & $3.0 \%$ \\
\hline KT06-11 & $\mathrm{Nb}_{2} \mathrm{O}_{5}$ & 0.4753 & 0.5399 & -0.0647 & $-12.0 \%$ \\
\hline KT06-11 & $\mathrm{NiO}$ & 0.3649 & 0.4247 & -0.0599 & $-14.1 \%$ \\
\hline KT06-11 & $\mathrm{PbO}$ & 0.0544 & 0.0636 & -0.0092 & $-14.5 \%$ \\
\hline KT06-11 & $\mathrm{SiO}_{2}$ & 46.2089 & 47.7869 & -1.5780 & $-3.3 \%$ \\
\hline KT06-11 & $\mathrm{SO}_{4}$ & 0.1498 & 0.1779 & -0.0281 & $-15.8 \%$ \\
\hline KT06-11 & $\mathrm{TiO}_{2}$ & 6.0048 & 6.0000 & 0.0048 & $0.1 \%$ \\
\hline KT06-11 & $\mathrm{ZnO}$ & 0.0277 & 0.0298 & -0.0021 & $-7.1 \%$ \\
\hline KT06-11 & $\mathrm{ZrO}_{2}$ & 0.5521 & 0.5906 & -0.0385 & $-6.5 \%$ \\
\hline KT06-11 & Sum & 98.4134 & 100.0000 & -1.5866 & $-1.6 \%$ \\
\hline KT06-12 & $\mathrm{Al}_{2} \mathrm{O}_{3}$ & 6.3251 & 6.2876 & 0.0375 & $0.6 \%$ \\
\hline KT06-12 & $\mathrm{B}_{2} \mathrm{O}_{3}$ & 8.2349 & 8.4000 & -0.1651 & $-2.0 \%$ \\
\hline KT06-12 & $\mathrm{BaO}$ & 0.0918 & 0.1066 & -0.0148 & $-13.9 \%$ \\
\hline KT06-12 & $\mathrm{CaO}$ & 1.2079 & 1.0313 & 0.1765 & $17.1 \%$ \\
\hline KT06-12 & $\mathrm{Ce}_{2} \mathrm{O}_{3}$ & 0.4214 & 0.4407 & -0.0193 & $-4.4 \%$ \\
\hline KT06-12 & $\mathrm{Cr}_{2} \mathrm{O}_{3}$ & 0.1809 & 0.2092 & -0.0283 & $-13.5 \%$ \\
\hline KT06-12 & $\mathrm{CuO}$ & 0.0723 & 0.0598 & 0.0125 & $20.9 \%$ \\
\hline KT06-12 & $\mathrm{Fe}_{2} \mathrm{O}_{3}$ & 10.3796 & 10.6649 & -0.2852 & $-2.7 \%$ \\
\hline KT06-12 & $\mathrm{K}_{2} \mathrm{O}$ & 0.2096 & 0.1711 & 0.0385 & $22.5 \%$ \\
\hline KT06-12 & $\mathrm{La}_{2} \mathrm{O}_{3}$ & 0.1264 & 0.1641 & -0.0377 & $-23.0 \%$ \\
\hline KT06-12 & $\mathrm{Li}_{2} \mathrm{O}$ & 5.2315 & 5.4000 & -0.1685 & $-3.1 \%$ \\
\hline KT06-12 & $\mathrm{MgO}$ & 0.2417 & 0.2379 & 0.0038 & $1.6 \%$ \\
\hline KT06-12 & $\mathrm{MnO}$ & 0.5062 & 0.5274 & -0.0212 & $-4.0 \%$ \\
\hline KT06-12 & $\mathrm{Na}_{2} \mathrm{O}$ & 9.4529 & 9.2000 & 0.2529 & $2.7 \%$ \\
\hline KT06-12 & $\mathrm{Nb}_{2} \mathrm{O}_{5}$ & 2.2155 & 2.5016 & -0.2861 & $-11.4 \%$ \\
\hline
\end{tabular}


Table A-4. Comparison of Measured versus Targeted Compositions for the KT06-Series Glasses. (continued)

\begin{tabular}{|c|c|c|c|c|c|}
\hline Glass ID & Oxide & $\begin{array}{c}\text { Measured } \\
(\mathrm{wt} \%)\end{array}$ & $\begin{array}{c}\text { Targeted } \\
(\mathrm{wt} \%)\end{array}$ & $\begin{array}{c}\text { Difference of } \\
\text { Measured vs Targeted }\end{array}$ & $\begin{array}{c}\text { \% Difference of } \\
\text { Measured vs Targeted }\end{array}$ \\
\hline KT06-12 & $\mathrm{NiO}$ & 0.1381 & 0.1699 & -0.0319 & $-18.8 \%$ \\
\hline KT06-12 & $\mathrm{PbO}$ & 0.2095 & 0.2508 & -0.0413 & $-16.5 \%$ \\
\hline KT06-12 & $\mathrm{SiO}_{2}$ & 43.5882 & 45.5567 & -1.9684 & $-4.3 \%$ \\
\hline KT06-12 & $\mathrm{SO}_{4}$ & 0.1498 & 0.2344 & -0.0846 & $-36.1 \%$ \\
\hline KT06-12 & $\mathrm{TiO}_{2}$ & 5.9798 & 6.0000 & -0.0202 & $-0.3 \%$ \\
\hline KT06-12 & $\mathrm{ZnO}$ & 0.1123 & 0.1184 & -0.0060 & $-5.1 \%$ \\
\hline KT06-12 & $\mathrm{ZrO}_{2}$ & 2.0948 & 2.2677 & -0.1730 & $-7.6 \%$ \\
\hline KT06-12 & Sum & 97.1700 & 100.0000 & -2.8300 & $-2.8 \%$ \\
\hline KT06-13 & $\mathrm{Al}_{2} \mathrm{O}_{3}$ & 9.5703 & 9.4424 & 0.1279 & $1.4 \%$ \\
\hline KT06-13 & $\mathrm{B}_{2} \mathrm{O}_{3}$ & 8.4200 & 8.4000 & 0.0200 & $0.2 \%$ \\
\hline KT06-13 & $\mathrm{BaO}$ & 0.0606 & 0.0734 & -0.0128 & $-17.5 \%$ \\
\hline KT06-13 & $\mathrm{CaO}$ & 0.7447 & 0.7099 & 0.0348 & $4.9 \%$ \\
\hline KT06-13 & $\mathrm{Ce}_{2} \mathrm{O}_{3}$ & 0.2876 & 0.3033 & -0.0158 & $-5.2 \%$ \\
\hline KT06-13 & $\mathrm{Cr}_{2} \mathrm{O}_{3}$ & 0.1348 & 0.1440 & -0.0092 & $-6.4 \%$ \\
\hline KT06-13 & $\mathrm{CuO}$ & 0.0444 & 0.0411 & 0.0033 & $8.0 \%$ \\
\hline KT06-13 & $\mathrm{Fe}_{2} \mathrm{O}_{3}$ & 7.3236 & 7.2482 & 0.0754 & $1.0 \%$ \\
\hline KT06-13 & $\mathrm{K}_{2} \mathrm{O}$ & 0.1412 & 0.1178 & 0.0235 & $19.9 \%$ \\
\hline KT06-13 & $\mathrm{La}_{2} \mathrm{O}_{3}$ & 0.0850 & 0.1129 & -0.0279 & $-24.7 \%$ \\
\hline KT06-13 & $\mathrm{Li}_{2} \mathrm{O}$ & 5.2208 & 5.4000 & -0.1792 & $-3.3 \%$ \\
\hline KT06-13 & $\mathrm{MgO}$ & 0.1472 & 0.1638 & -0.0166 & $-10.1 \%$ \\
\hline KT06-13 & $\mathrm{MnO}$ & 3.3378 & 3.4002 & -0.0625 & $-1.8 \%$ \\
\hline KT06-13 & $\mathrm{Na}_{2} \mathrm{O}$ & 9.4192 & 9.2000 & 0.2192 & $2.4 \%$ \\
\hline KT06-13 & $\mathrm{Nb}_{2} \mathrm{O}_{5}$ & 0.0286 & 0.0803 & -0.0517 & $-64.4 \%$ \\
\hline KT06-13 & $\mathrm{NiO}$ & 0.0983 & 0.1170 & -0.0187 & $-16.0 \%$ \\
\hline KT06-13 & $\mathrm{PbO}$ & 0.1406 & 0.1726 & -0.0321 & $-18.6 \%$ \\
\hline KT06-13 & $\mathrm{SiO}_{2}$ & 47.3855 & 48.4365 & -1.0511 & $-2.2 \%$ \\
\hline KT06-13 & $\mathrm{SO}_{4}$ & 0.1498 & 0.1613 & -0.0115 & $-7.2 \%$ \\
\hline KT06-13 & $\mathrm{TiO}_{2}$ & 5.8797 & 6.0000 & -0.1203 & $-2.0 \%$ \\
\hline KT06-13 & $\mathrm{ZnO}$ & 0.0734 & 0.0815 & -0.0080 & $-9.9 \%$ \\
\hline KT06-13 & $\mathrm{ZrO}_{2}$ & 0.1101 & 0.1936 & -0.0835 & $-43.1 \%$ \\
\hline KT06-13 & Sum & 98.8032 & 100.0000 & -1.1968 & $-1.2 \%$ \\
\hline KT06-14 & $\mathrm{Al}_{2} \mathrm{O}_{3}$ & 11.6346 & 11.4195 & 0.2151 & $1.9 \%$ \\
\hline KT06-14 & $\mathrm{B}_{2} \mathrm{O}_{3}$ & 8.1141 & 8.4000 & -0.2859 & $-3.4 \%$ \\
\hline KT06-14 & $\mathrm{BaO}$ & 0.0229 & 0.0298 & -0.0069 & $-23.1 \%$ \\
\hline KT06-14 & $\mathrm{CaO}$ & 2.1828 & 2.1024 & 0.0803 & $3.8 \%$ \\
\hline KT06-14 & $\mathrm{Ce}_{2} \mathrm{O}_{3}$ & 0.1177 & 0.1224 & -0.0047 & $-3.9 \%$ \\
\hline KT06-14 & $\mathrm{Cr}_{2} \mathrm{O}_{3}$ & 0.0552 & 0.0580 & -0.0029 & $-4.9 \%$ \\
\hline KT06-14 & $\mathrm{CuO}$ & 0.0175 & 0.0166 & 0.0009 & $5.7 \%$ \\
\hline KT06-14 & $\mathrm{Fe}_{2} \mathrm{O}_{3}$ & 8.2208 & 8.7659 & -0.5451 & $-6.2 \%$ \\
\hline KT06-14 & $\mathrm{K}_{2} \mathrm{O}$ & 0.0527 & 0.0473 & 0.0054 & $11.4 \%$ \\
\hline KT06-14 & $\mathrm{La}_{2} \mathrm{O}_{3}$ & 0.0317 & 0.0454 & -0.0137 & $-30.2 \%$ \\
\hline KT06-14 & $\mathrm{Li}_{2} \mathrm{O}$ & 5.2908 & 5.4000 & -0.1092 & $-2.0 \%$ \\
\hline KT06-14 & $\mathrm{MgO}$ & 0.0543 & 0.0659 & -0.0115 & $-17.5 \%$ \\
\hline KT06-14 & $\mathrm{MnO}$ & 0.4451 & 0.4390 & 0.0061 & $1.4 \%$ \\
\hline KT06-14 & $\mathrm{Na}_{2} \mathrm{O}$ & 9.8033 & 9.2000 & 0.6033 & $6.6 \%$ \\
\hline KT06-14 & $\mathrm{Nb}_{2} \mathrm{O}_{5}$ & 0.1012 & 0.0976 & 0.0036 & $3.7 \%$ \\
\hline KT06-14 & $\mathrm{NiO}$ & 0.1285 & 0.1415 & -0.0129 & $-9.1 \%$ \\
\hline KT06-14 & $\mathrm{PbO}$ & 0.0584 & 0.0698 & -0.0113 & $-16.2 \%$ \\
\hline KT06-14 & $\mathrm{SiO}_{2}$ & 43.4278 & 45.4634 & -2.0356 & $-4.5 \%$ \\
\hline KT06-14 & $\mathrm{SO}_{4}$ & 0.1498 & 0.1951 & -0.0453 & $-23.2 \%$ \\
\hline KT06-14 & $\mathrm{TiO}_{2}$ & 6.0048 & 6.0000 & 0.0048 & $0.1 \%$ \\
\hline KT06-14 & $\mathrm{ZnO}$ & 0.0230 & 0.0327 & -0.0097 & $-29.5 \%$ \\
\hline KT06-14 & $\mathrm{ZrO}_{2}$ & 1.8357 & 1.8878 & -0.0521 & $-2.8 \%$ \\
\hline KT06-14 & Sum & 97.7728 & 100.0000 & -2.2272 & $-2.2 \%$ \\
\hline KT06-15 & $\mathrm{Al}_{2} \mathrm{O}_{3}$ & 6.2920 & 6.2876 & 0.0045 & $0.1 \%$ \\
\hline KT06-15 & $\mathrm{B}_{2} \mathrm{O}_{3}$ & 4.6930 & 4.8000 & -0.1070 & $-2.2 \%$ \\
\hline KT06-15 & $\mathrm{BaO}$ & 0.0955 & 0.1066 & -0.0112 & $-10.5 \%$ \\
\hline KT06-15 & $\mathrm{CaO}$ & 1.0718 & 1.0313 & 0.0405 & $3.9 \%$ \\
\hline
\end{tabular}


Table A-4. Comparison of Measured versus Targeted Compositions for the KT06-Series Glasses. (continued)

\begin{tabular}{|c|c|c|c|c|c|}
\hline Glass ID & Oxide & $\begin{array}{c}\text { Measured } \\
\text { (wt\%) }\end{array}$ & $\begin{array}{c}\text { Targeted } \\
(\mathrm{wt} \%)\end{array}$ & $\begin{array}{c}\text { Difference of } \\
\text { Measured vs Targeted }\end{array}$ & $\begin{array}{c}\text { \% Difference of } \\
\text { Measured vs Targeted }\end{array}$ \\
\hline KT06-15 & $\mathrm{Ce}_{2} \mathrm{O}_{3}$ & 0.4302 & 0.4407 & -0.0105 & $-2.4 \%$ \\
\hline KT06-15 & $\mathrm{Cr}_{2} \mathrm{O}_{3}$ & 0.1717 & 0.2092 & -0.0375 & $-17.9 \%$ \\
\hline KT06-15 & $\mathrm{CuO}$ & 0.0879 & 0.0598 & 0.0282 & $47.1 \%$ \\
\hline KT06-15 & $\mathrm{Fe}_{2} \mathrm{O}_{3}$ & 10.3653 & 10.6649 & -0.2995 & $-2.8 \%$ \\
\hline KT06-15 & $\mathrm{K}_{2} \mathrm{O}$ & 0.1873 & 0.1711 & 0.0162 & $9.5 \%$ \\
\hline KT06-15 & $\mathrm{La}_{2} \mathrm{O}_{3}$ & 0.1311 & 0.1641 & -0.0330 & $-20.1 \%$ \\
\hline KT06-15 & $\mathrm{Li}_{2} \mathrm{O}$ & 6.3995 & 6.6000 & -0.2005 & $-3.0 \%$ \\
\hline KT06-15 & $\mathrm{MgO}$ & 0.2251 & 0.2379 & -0.0128 & $-5.4 \%$ \\
\hline KT06-15 & $\mathrm{MnO}$ & 0.5187 & 0.5274 & -0.0086 & $-1.6 \%$ \\
\hline KT06-15 & $\mathrm{Na}_{2} \mathrm{O}$ & 10.0123 & 9.2000 & 0.8123 & $8.8 \%$ \\
\hline KT06-15 & $\mathrm{Nb}_{2} \mathrm{O}_{5}$ & 2.3006 & 2.5016 & -0.2010 & $-8.0 \%$ \\
\hline KT06-15 & $\mathrm{NiO}$ & 0.1514 & 0.1699 & -0.0185 & $-10.9 \%$ \\
\hline KT06-15 & $\mathrm{PbO}$ & 0.2238 & 0.2508 & -0.0270 & $-10.8 \%$ \\
\hline KT06-15 & $\mathrm{SiO}_{2}$ & 45.8880 & 47.9567 & -2.0687 & $-4.3 \%$ \\
\hline KT06-15 & $\mathrm{SO}_{4}$ & 0.1498 & 0.2344 & -0.0846 & $-36.1 \%$ \\
\hline KT06-15 & $\mathrm{TiO}_{2}$ & 5.8297 & 6.0000 & -0.1703 & $-2.8 \%$ \\
\hline KT06-15 & $\mathrm{ZnO}$ & 0.1192 & 0.1184 & 0.0008 & $0.7 \%$ \\
\hline KT06-15 & $\mathrm{ZrO}_{2}$ & 2.0606 & 2.2677 & -0.2071 & $-9.1 \%$ \\
\hline KT06-15 & Sum & 97.4045 & 100.0000 & -2.5955 & $-2.6 \%$ \\
\hline KT06-16 & $\mathrm{Al}_{2} \mathrm{O}_{3}$ & 9.7640 & 9.4424 & 0.3215 & $3.4 \%$ \\
\hline KT06-16 & $\mathrm{B}_{2} \mathrm{O}_{3}$ & 4.8299 & 4.8000 & 0.0299 & $0.6 \%$ \\
\hline KT06-16 & $\mathrm{BaO}$ & 0.0597 & 0.0734 & -0.0137 & $-18.6 \%$ \\
\hline KT06-16 & $\mathrm{CaO}$ & 0.7538 & 0.7099 & 0.0439 & $6.2 \%$ \\
\hline KT06-16 & $\mathrm{Ce}_{2} \mathrm{O}_{3}$ & 0.2843 & 0.3033 & -0.0190 & $-6.3 \%$ \\
\hline KT06-16 & $\mathrm{Cr}_{2} \mathrm{O}_{3}$ & 0.1228 & 0.1440 & -0.0212 & $-14.7 \%$ \\
\hline KT06-16 & $\mathrm{CuO}$ & 0.0457 & 0.0411 & 0.0045 & $11.1 \%$ \\
\hline KT06-16 & $\mathrm{Fe}_{2} \mathrm{O}_{3}$ & 7.3379 & 7.2482 & 0.0897 & $1.2 \%$ \\
\hline KT06-16 & $\mathrm{K}_{2} \mathrm{O}$ & 0.1418 & 0.1178 & 0.0241 & $20.4 \%$ \\
\hline KT06-16 & $\mathrm{La}_{2} \mathrm{O}_{3}$ & 0.0844 & 0.1129 & -0.0285 & $-25.2 \%$ \\
\hline KT06-16 & $\mathrm{Li}_{2} \mathrm{O}$ & 6.5287 & 6.6000 & -0.0713 & $-1.1 \%$ \\
\hline KT06-16 & $\mathrm{MgO}$ & 0.1480 & 0.1638 & -0.0158 & $-9.6 \%$ \\
\hline KT06-16 & $\mathrm{MnO}$ & 3.3926 & 3.4002 & -0.0076 & $-0.2 \%$ \\
\hline KT06-16 & $\mathrm{Na}_{2} \mathrm{O}$ & 9.8438 & 9.2000 & 0.6438 & $7.0 \%$ \\
\hline KT06-16 & $\mathrm{Nb}_{2} \mathrm{O}_{5}$ & 0.0765 & 0.0803 & -0.0037 & $-4.7 \%$ \\
\hline KT06-16 & $\mathrm{NiO}$ & 0.0929 & 0.1170 & -0.0241 & $-20.6 \%$ \\
\hline KT06-16 & $\mathrm{PbO}$ & 0.1382 & 0.1726 & -0.0345 & $-20.0 \%$ \\
\hline KT06-16 & $\mathrm{SiO}_{2}$ & 49.3643 & 50.8365 & -1.4722 & $-2.9 \%$ \\
\hline KT06-16 & $\mathrm{SO}_{4}$ & 0.1498 & 0.1613 & -0.0115 & $-7.2 \%$ \\
\hline KT06-16 & $\mathrm{TiO}_{2}$ & 6.0048 & 6.0000 & 0.0048 & $0.1 \%$ \\
\hline KT06-16 & $\mathrm{ZnO}$ & 0.0787 & 0.0815 & -0.0027 & $-3.4 \%$ \\
\hline КT06-16 & $\mathrm{ZrO}_{2}$ & 0.1834 & 0.1936 & -0.0102 & $-5.3 \%$ \\
\hline KT06-16 & Sum & 99.4261 & 100.0000 & -0.5739 & $-0.6 \%$ \\
\hline KT06-17 & $\mathrm{Al}_{2} \mathrm{O}_{3}$ & 11.5590 & 11.4195 & 0.1395 & $1.2 \%$ \\
\hline KT06-17 & $\mathrm{B}_{2} \mathrm{O}_{3}$ & 4.7172 & 4.8000 & -0.0828 & $-1.7 \%$ \\
\hline KT06-17 & $\mathrm{BaO}$ & 0.0218 & 0.0298 & -0.0080 & $-26.8 \%$ \\
\hline KT06-17 & $\mathrm{CaO}$ & 2.2807 & 2.1024 & 0.1783 & $8.5 \%$ \\
\hline KT06-17 & $\mathrm{Ce}_{2} \mathrm{O}_{3}$ & 0.1133 & 0.1224 & -0.0091 & $-7.4 \%$ \\
\hline KT06-17 & $\mathrm{Cr}_{2} \mathrm{O}_{3}$ & 0.0581 & 0.0580 & 0.0000 & $0.1 \%$ \\
\hline KT06-17 & $\mathrm{CuO}$ & 0.0253 & 0.0166 & 0.0088 & $52.8 \%$ \\
\hline KT06-17 & $\mathrm{Fe}_{2} \mathrm{O}_{3}$ & 8.4960 & 8.7659 & -0.2699 & $-3.1 \%$ \\
\hline KT06-17 & $\mathrm{K}_{2} \mathrm{O}$ & 0.0635 & 0.0473 & 0.0162 & $34.3 \%$ \\
\hline KT06-17 & $\mathrm{La}_{2} \mathrm{O}_{3}$ & 0.0325 & 0.0454 & -0.0128 & $-28.3 \%$ \\
\hline KT06-17 & $\mathrm{Li}_{2} \mathrm{O}$ & 6.4264 & 6.6000 & -0.1736 & $-2.6 \%$ \\
\hline KT06-17 & $\mathrm{MgO}$ & 0.0759 & 0.0659 & 0.0100 & $15.2 \%$ \\
\hline KT06-17 & $\mathrm{MnO}$ & 0.4232 & 0.4390 & -0.0158 & $-3.6 \%$ \\
\hline KT06-17 & $\mathrm{Na}_{2} \mathrm{O}$ & 9.6719 & 9.2000 & 0.4719 & $5.1 \%$ \\
\hline KT06-17 & $\mathrm{Nb}_{2} \mathrm{O}_{5}$ & 0.0679 & 0.0976 & -0.0296 & $-30.4 \%$ \\
\hline KT06-17 & $\mathrm{NiO}$ & 0.1209 & 0.1415 & -0.0206 & $-14.5 \%$ \\
\hline
\end{tabular}


Table A-4. Comparison of Measured versus Targeted Compositions for the KT06-Series Glasses. (continued)

\begin{tabular}{|c|c|c|c|c|c|}
\hline Glass ID & Oxide & $\begin{array}{l}\text { Measured } \\
\text { (wt \%) }\end{array}$ & $\begin{array}{l}\text { Targeted } \\
\text { (wt } \%)\end{array}$ & $\begin{array}{c}\text { Difference of } \\
\text { Measured vs Targeted }\end{array}$ & $\begin{array}{c}\text { \% Difference of } \\
\text { Measured vs Targeted }\end{array}$ \\
\hline KT06-17 & $\mathrm{PbO}$ & 0.0574 & 0.0698 & -0.0124 & $-17.8 \%$ \\
\hline KT06-17 & $\mathrm{SiO}_{2}$ & 45.8345 & 47.8634 & -2.0289 & $-4.2 \%$ \\
\hline KT06-17 & $\mathrm{SO}_{4}$ & 0.1498 & 0.1951 & -0.0453 & $-23.2 \%$ \\
\hline KT06-17 & $\mathrm{TiO}_{2}$ & 5.9381 & 6.0000 & -0.0619 & $-1.0 \%$ \\
\hline KT06-17 & $\mathrm{ZnO}$ & 0.0249 & 0.0327 & -0.0078 & $-23.8 \%$ \\
\hline KT06-17 & $\mathrm{ZrO}_{2}$ & 1.7061 & 1.8878 & -0.1817 & $-9.6 \%$ \\
\hline KT06-17 & Sum & 97.8644 & 100.0000 & -2.1356 & $-2.1 \%$ \\
\hline KT06-18 & $\mathrm{Al}_{2} \mathrm{O}_{3}$ & 5.4418 & 5.3317 & 0.1100 & $2.1 \%$ \\
\hline KT06-18 & $\mathrm{B}_{2} \mathrm{O}_{3}$ & 4.8057 & 4.8000 & 0.0057 & $0.1 \%$ \\
\hline KT06-18 & $\mathrm{BaO}$ & 0.0190 & 0.0271 & -0.0081 & $-30.0 \%$ \\
\hline KT06-18 & $\mathrm{CaO}$ & 1.1257 & 1.0665 & 0.0591 & $5.5 \%$ \\
\hline KT06-18 & $\mathrm{Ce}_{2} \mathrm{O}_{3}$ & 0.1042 & 0.1116 & -0.0074 & $-6.6 \%$ \\
\hline KT06-18 & $\mathrm{Cr}_{2} \mathrm{O}_{3}$ & 0.0541 & 0.0529 & 0.0012 & $2.2 \%$ \\
\hline KT06-18 & $\mathrm{CuO}$ & 0.0488 & 0.0151 & 0.0337 & $222.8 \%$ \\
\hline KT06-18 & $\mathrm{Fe}_{2} \mathrm{O}_{3}$ & 14.4150 & 14.5991 & -0.1842 & $-1.3 \%$ \\
\hline KT06-18 & $\mathrm{K}_{2} \mathrm{O}$ & 0.0608 & 0.0431 & 0.0177 & $41.0 \%$ \\
\hline KT06-18 & $\mathrm{La}_{2} \mathrm{O}_{3}$ & 0.0281 & 0.0414 & -0.0132 & $-31.9 \%$ \\
\hline KT06-18 & $\mathrm{Li}_{2} \mathrm{O}$ & 4.6718 & 4.8000 & -0.1282 & $-2.7 \%$ \\
\hline KT06-18 & $\mathrm{MgO}$ & 0.0489 & 0.0600 & -0.0111 & $-18.5 \%$ \\
\hline KT06-18 & $\mathrm{MnO}$ & 1.1450 & 1.2378 & -0.0928 & $-7.5 \%$ \\
\hline KT06-18 & $\mathrm{Na}_{2} \mathrm{O}$ & 9.6416 & 9.2000 & 0.4416 & $4.8 \%$ \\
\hline KT06-18 & $\mathrm{Nb}_{2} \mathrm{O}_{5}$ & 0.4928 & 0.5399 & -0.0471 & $-8.7 \%$ \\
\hline KT06-18 & $\mathrm{NiO}$ & 0.3617 & 0.4247 & -0.0630 & $-14.8 \%$ \\
\hline KT06-18 & $\mathrm{PbO}$ & 0.0533 & 0.0636 & -0.0103 & $-16.2 \%$ \\
\hline KT06-18 & $\mathrm{SiO}_{2}$ & 49.0435 & 50.7869 & -1.7434 & $-3.4 \%$ \\
\hline KT06-18 & $\mathrm{SO}_{4}$ & 0.1498 & 0.1779 & -0.0281 & $-15.8 \%$ \\
\hline KT06-18 & $\mathrm{TiO}_{2}$ & 5.9506 & 6.0000 & -0.0494 & $-0.8 \%$ \\
\hline KT06-18 & $\mathrm{ZnO}$ & 0.0324 & 0.0298 & 0.0026 & $8.6 \%$ \\
\hline KT06-18 & $\mathrm{ZrO}_{2}$ & 0.5559 & 0.5906 & -0.0348 & $-5.9 \%$ \\
\hline KT06-18 & Sum & 98.2503 & 100.0000 & -1.7497 & $-1.7 \%$ \\
\hline
\end{tabular}


Exhibit A-1. Measurements in Analytical Sequence for the KT06-Series by Preparation Method by Oxide. Series=KT6, Prep Method=LM, Oxide=Al2O3 (wt\%)

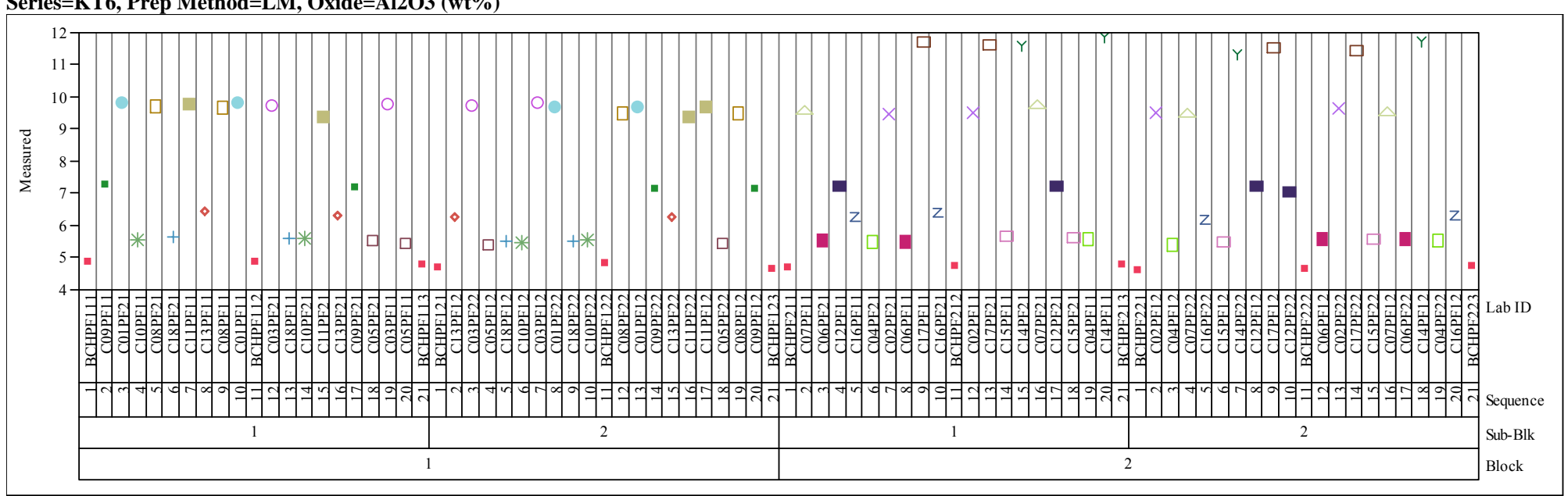

Series=KT6, Prep Method=LM, Oxide=B2O3 (wt\%)

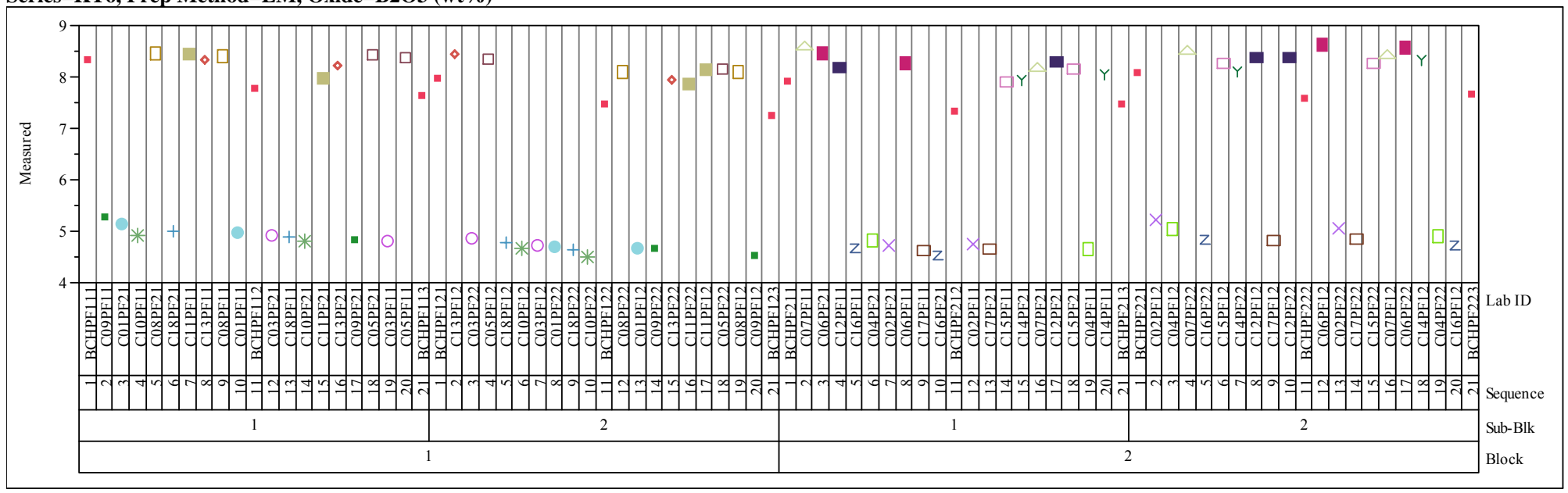


Exhibit A-1. Measurements in Analytical Sequence for the KT06-Series by Preparation Method by Oxide. (continued) Series=KT6, Prep Method=LM, Oxide=Fe2O3 (wt\%)

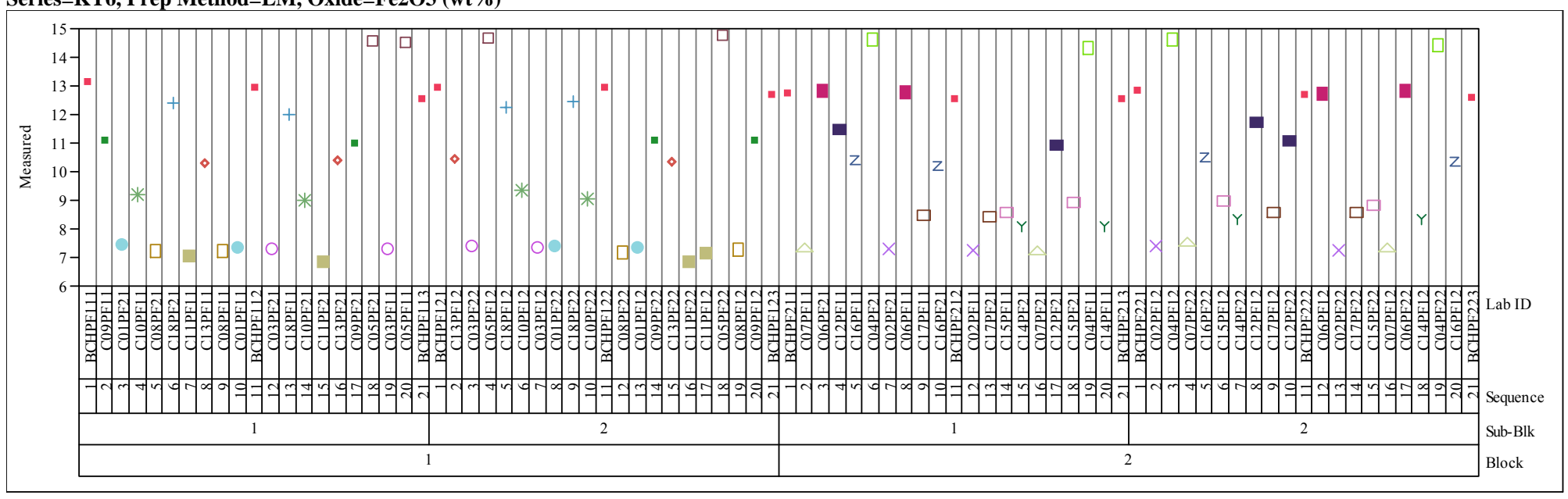

Series=KT6, Prep Method=LM, Oxide=Li2O (wt\%)

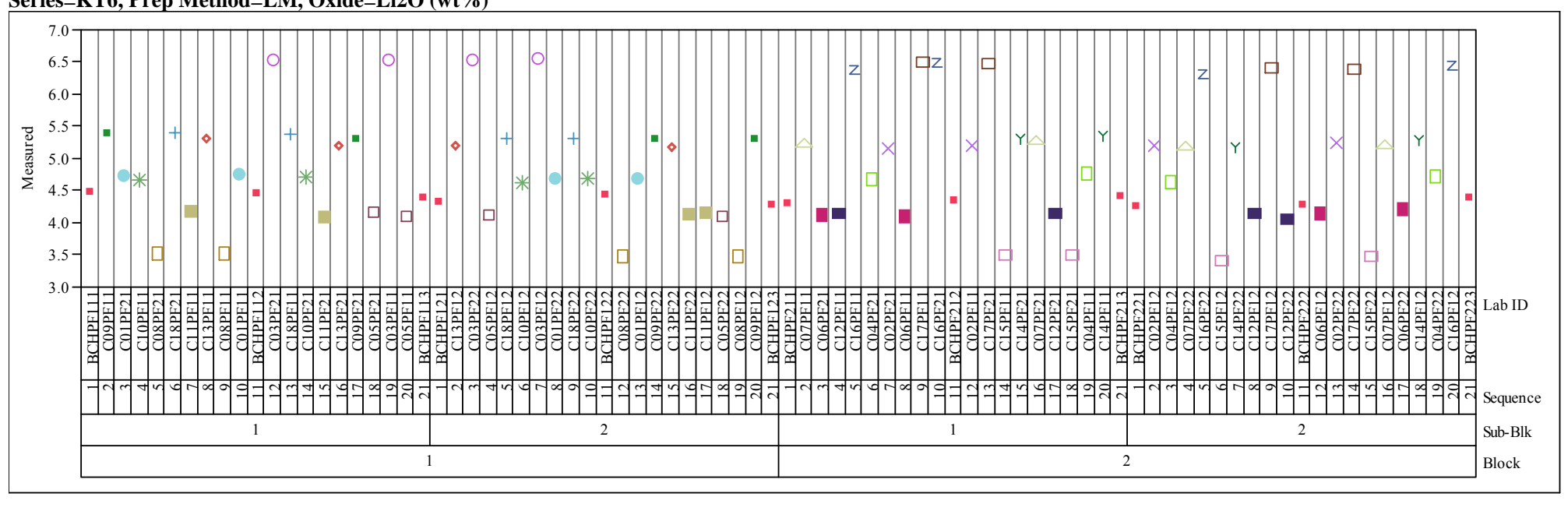


Exhibit A-1. Measurements in Analytical Sequence for the KT06-Series by Preparation Method by Oxide. (continued) Series=KT6, Prep Method=LM, Oxide=SiO2 (wt\%)
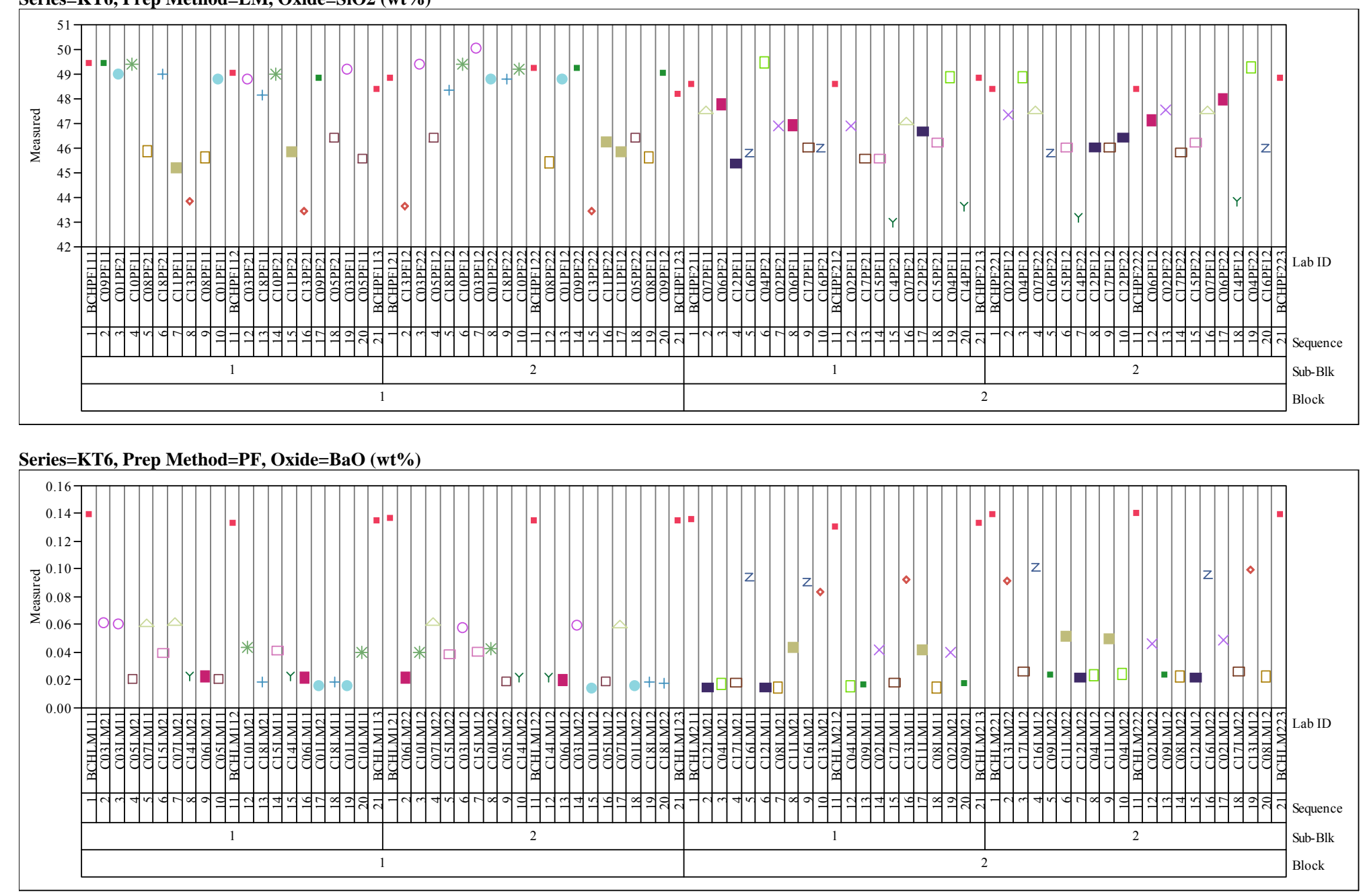
Exhibit A-1. Measurements in Analytical Sequence for the KT06-Series by Preparation Method by Oxide. (continued) Series $=$ KT6, Prep Method=PF, Oxide=CaO $(w t \%)$

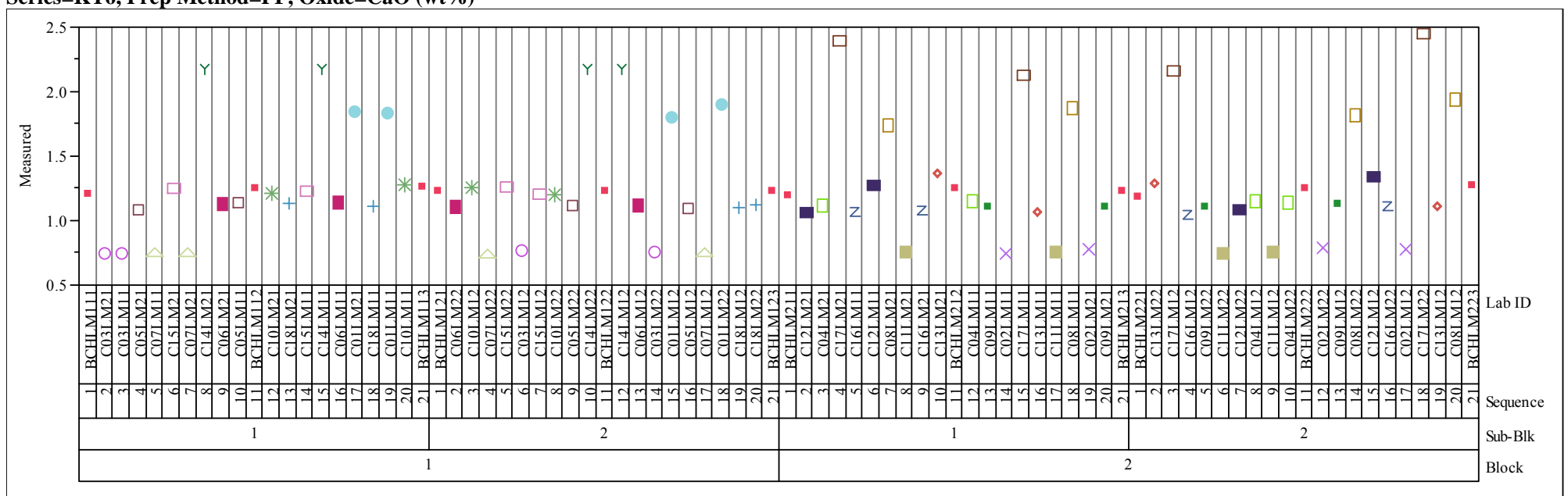

Series=KT6, Prep Method=PF, Oxide=Ce2O3 (wt\%)

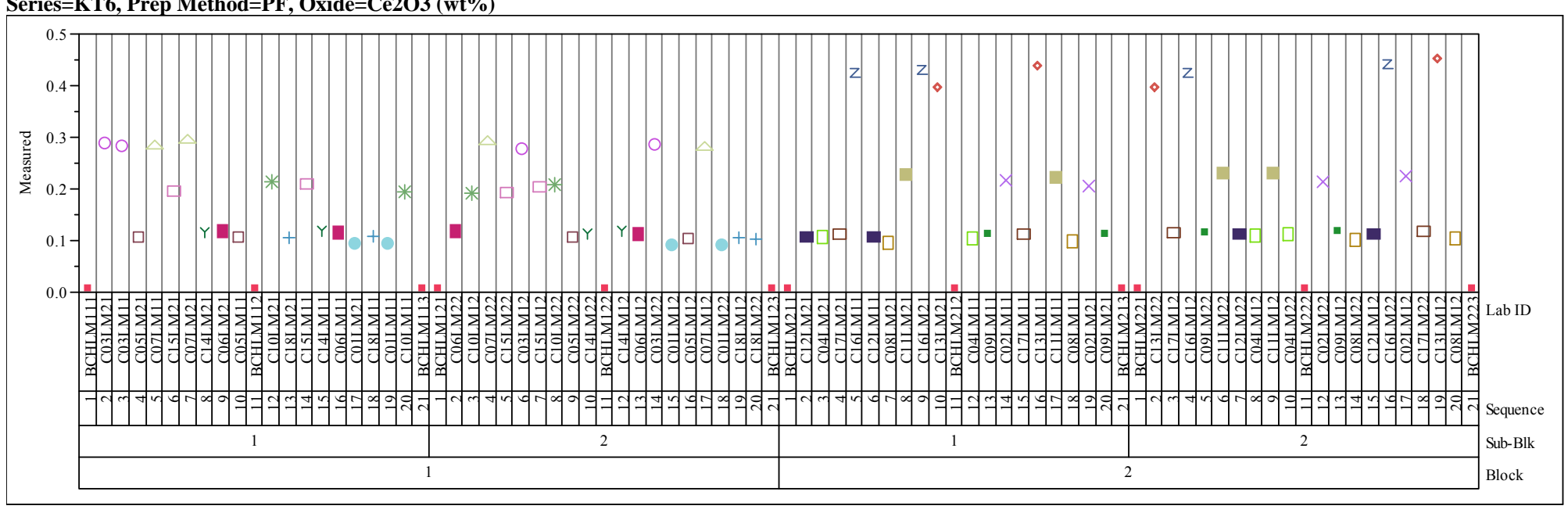


Exhibit A-1. Measurements in Analytical Sequence for the KT06-Series by Preparation Method by Oxide. (continued) Series=KT6, Prep Method=PF, Oxide=Cr2O3 (wt \%)

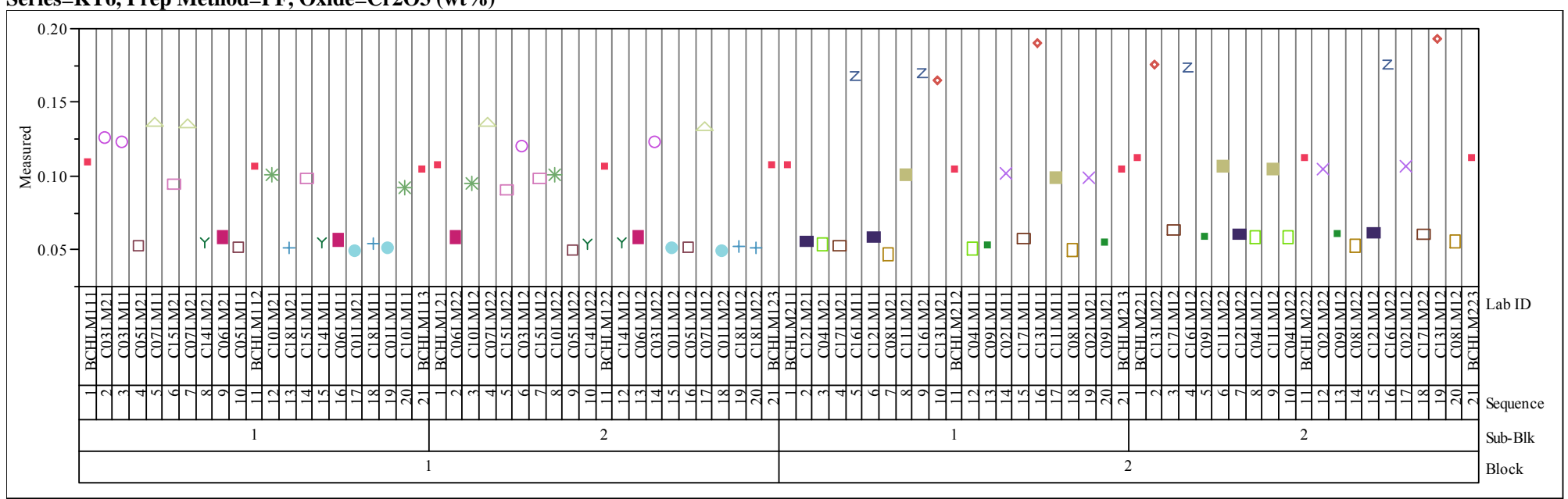

Series=KT6, Prep Method=PF, Oxide=CuO (wt $\%)$

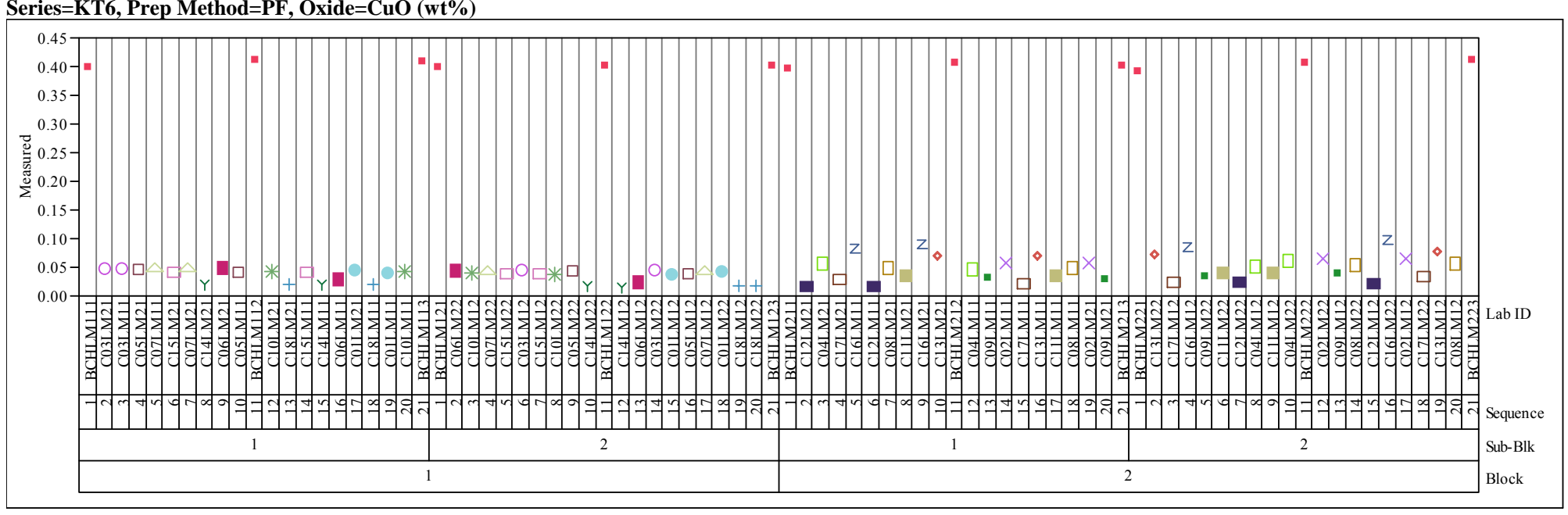


Exhibit A-1. Measurements in Analytical Sequence for the KT06-Series by Preparation Method by Oxide. (continued) Series=KT6, Prep Method=PF, Oxide=K2O (wt\%)

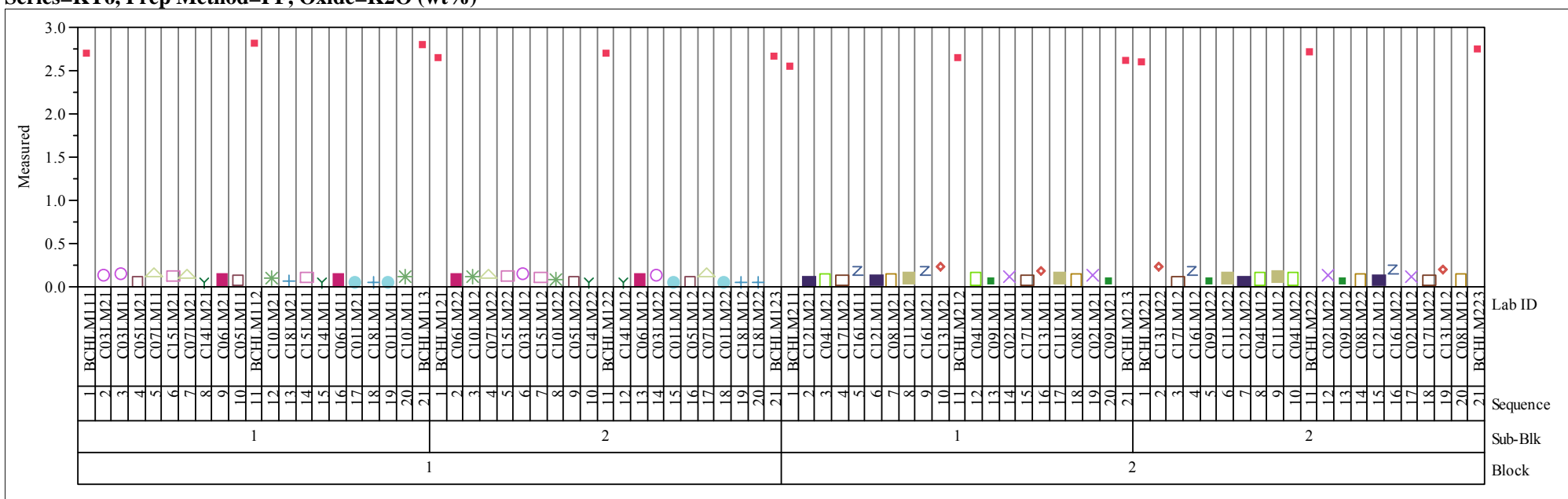

Series=KT6, Prep Method=PF, Oxide=La2O3 (wt\%)

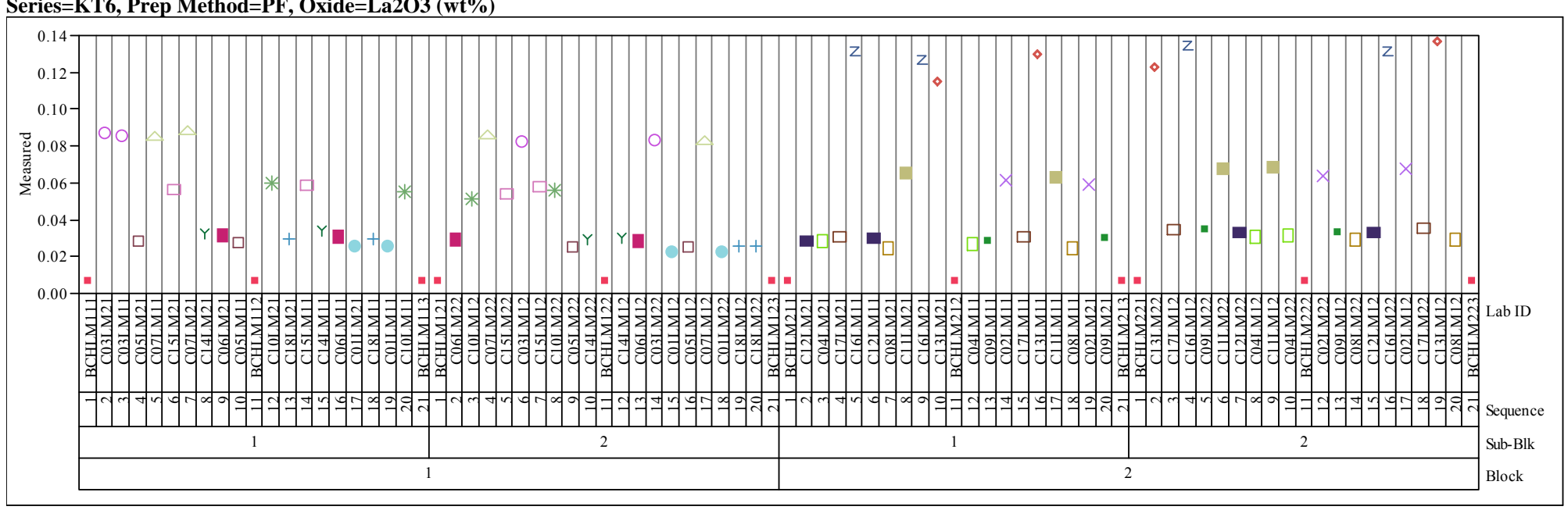


Exhibit A-1. Measurements in Analytical Sequence for the KT06-Series by Preparation Method by Oxide. (continued) Series=KT6, Prep Method=PF, Oxide=MgO (wt\%)

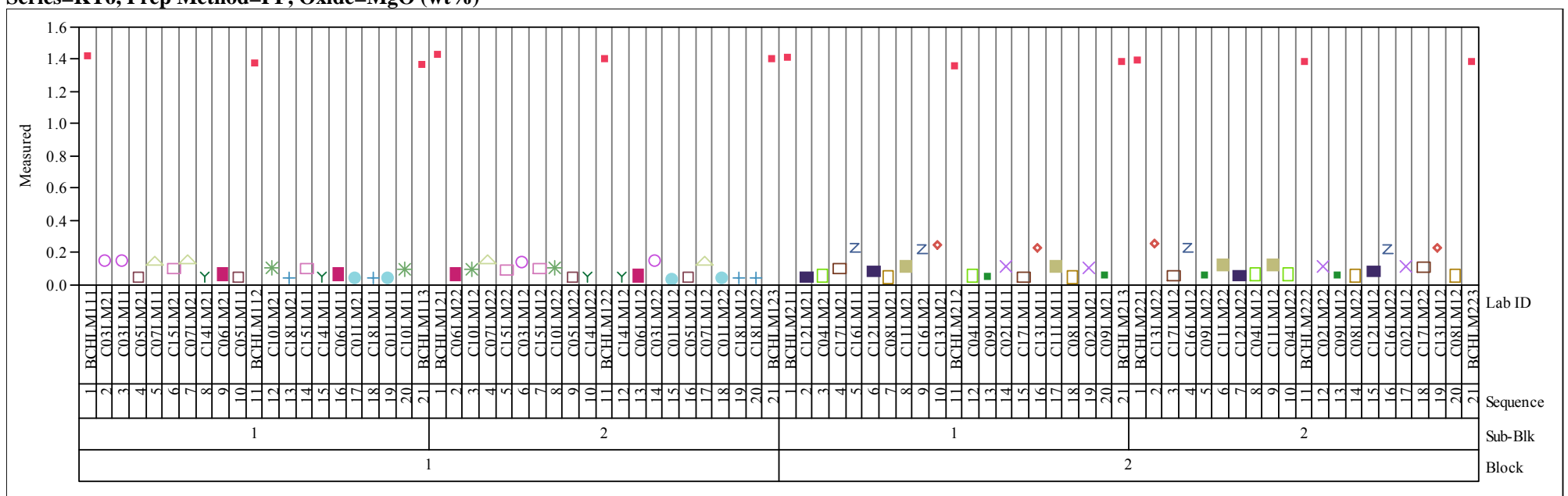

Series=KT6, Prep Method=PF, Oxide=MnO (wt\%)

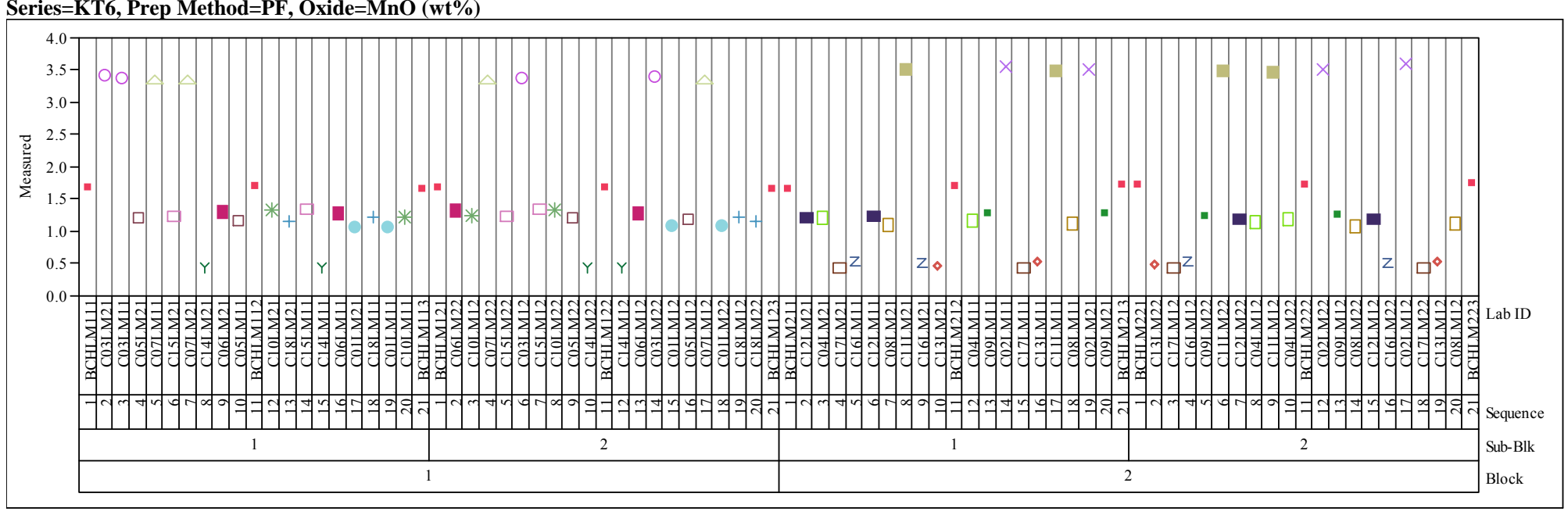


Exhibit A-1. Measurements in Analytical Sequence for the KT06-Series by Preparation Method by Oxide. (continued) Series=KT6, Prep Method=PF, Oxide=Na2O (wt\%)

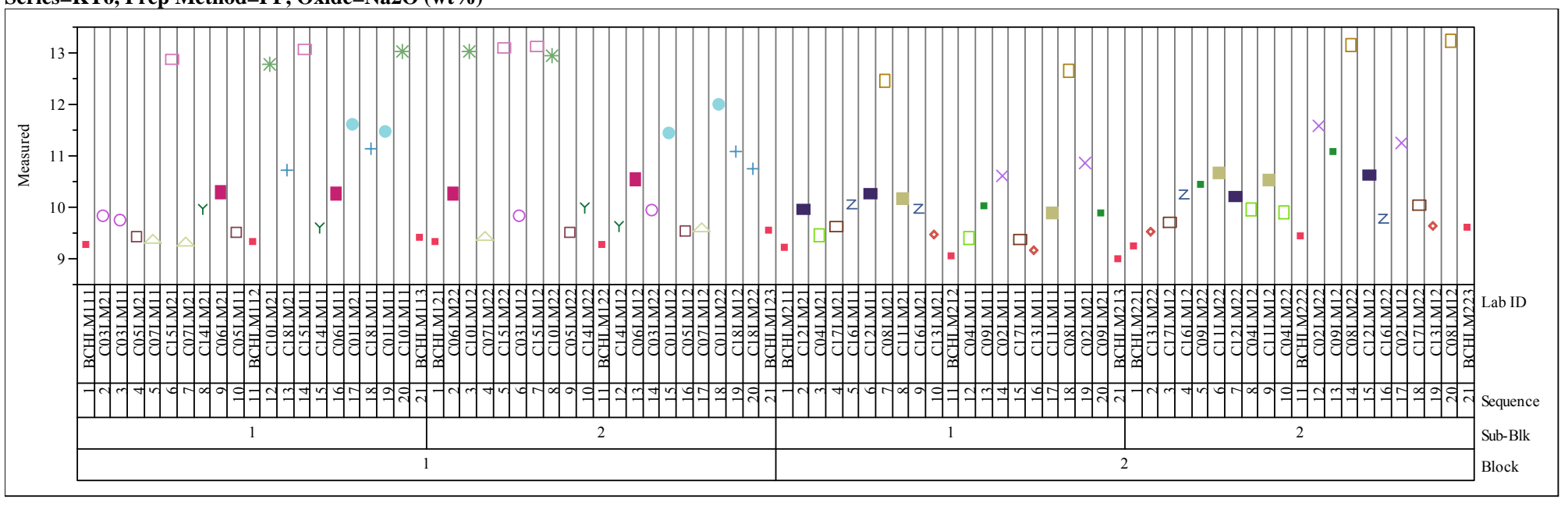

Series=KT6, Prep Method=PF, Oxide=Nb2O5 (wt\%)

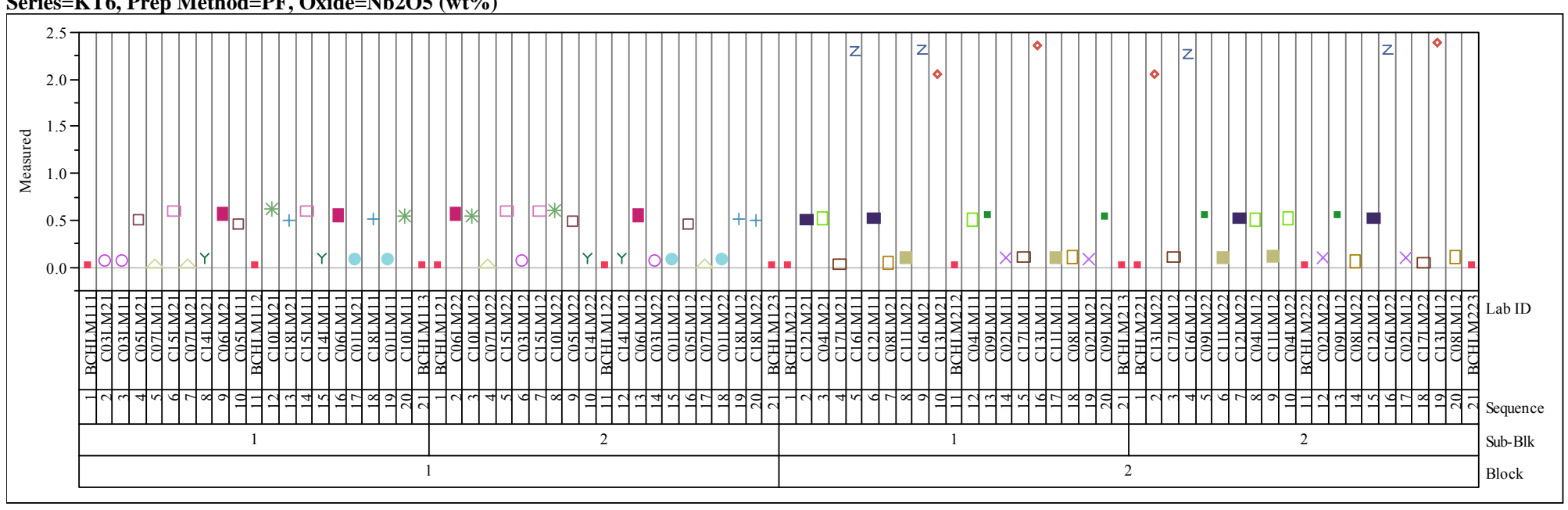


Exhibit A-1. Measurements in Analytical Sequence for the KT06-Series by Preparation Method by Oxide. (continued) Series=KT6, Prep Method=PF, Oxide=NiO (wt\%)

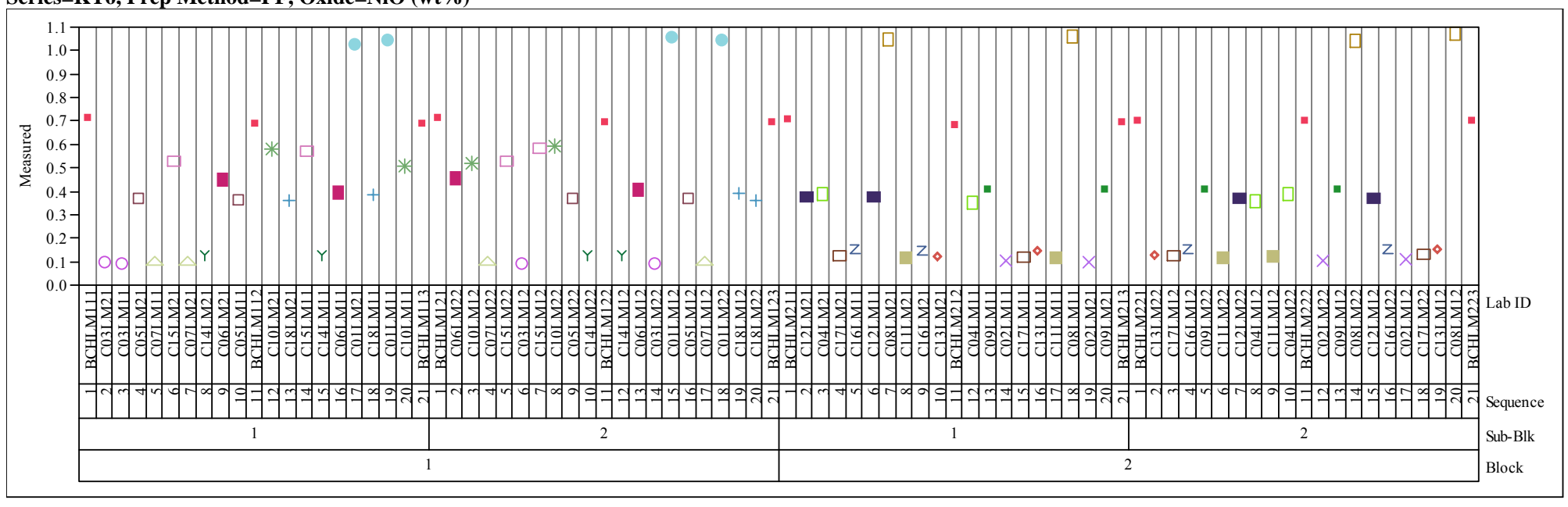

Series=KT6, Prep Method=PF, Oxide=PbO (wt\%)

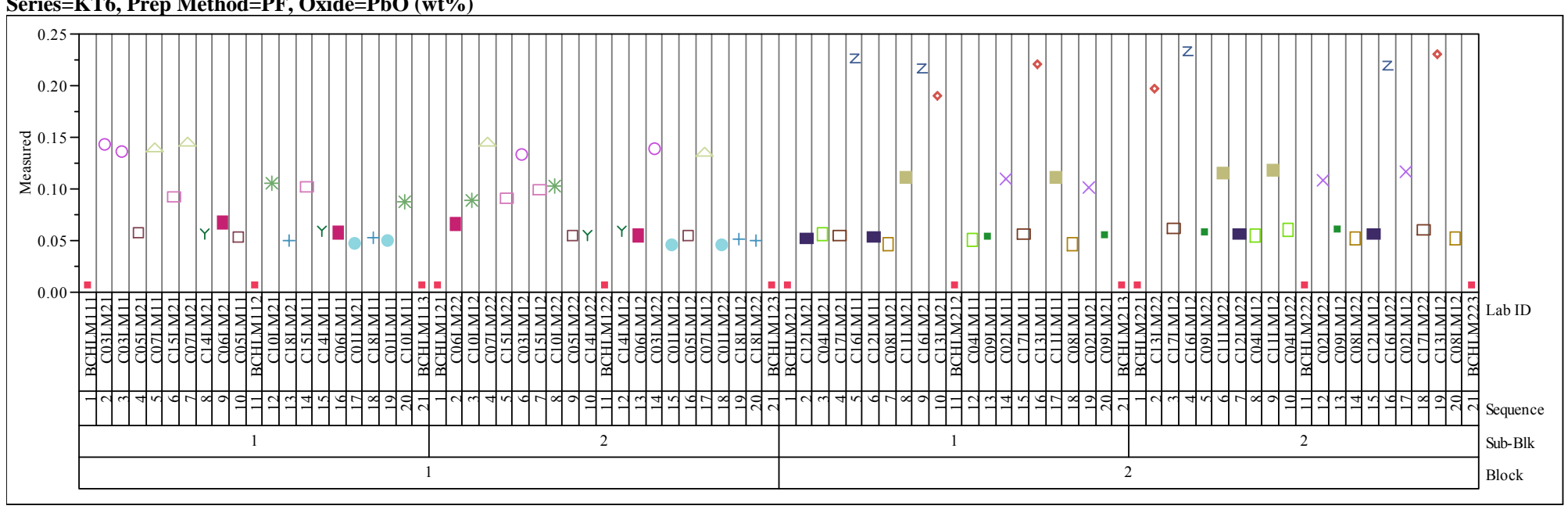


Exhibit A-1. Measurements in Analytical Sequence for the KT06-Series by Preparation Method by Oxide. (continued) Series=KT6, Prep Method=PF, Oxide=SO4 (wt\%)

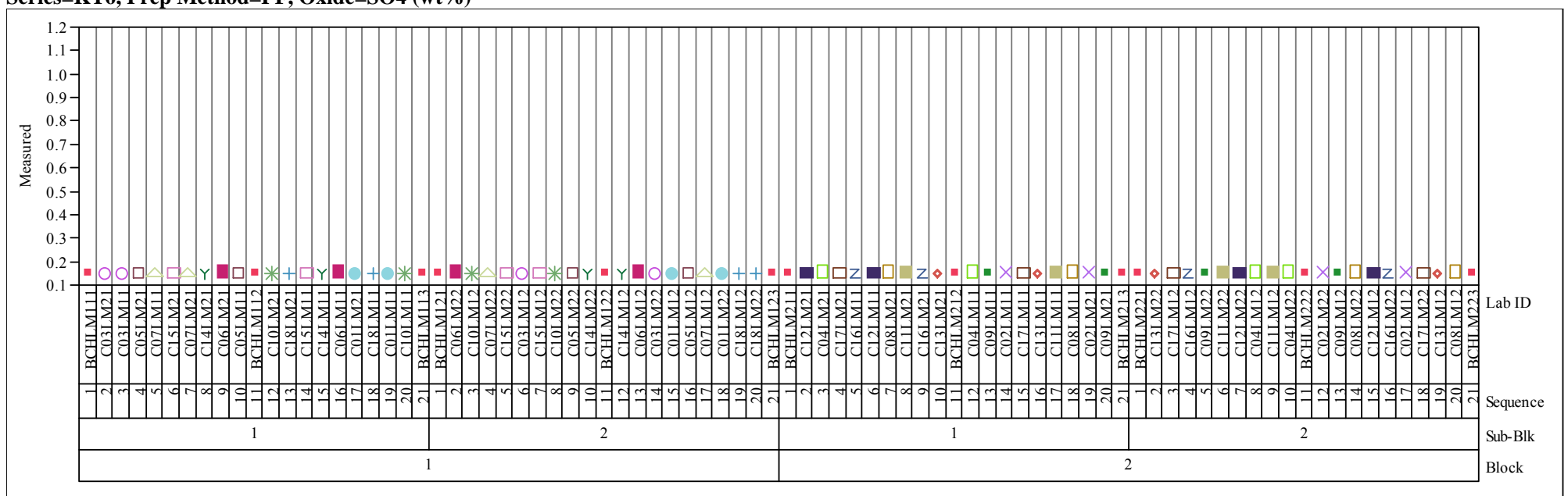

Series=KT6, Prep Method=PF, Oxide=TiO2 (wt\%)

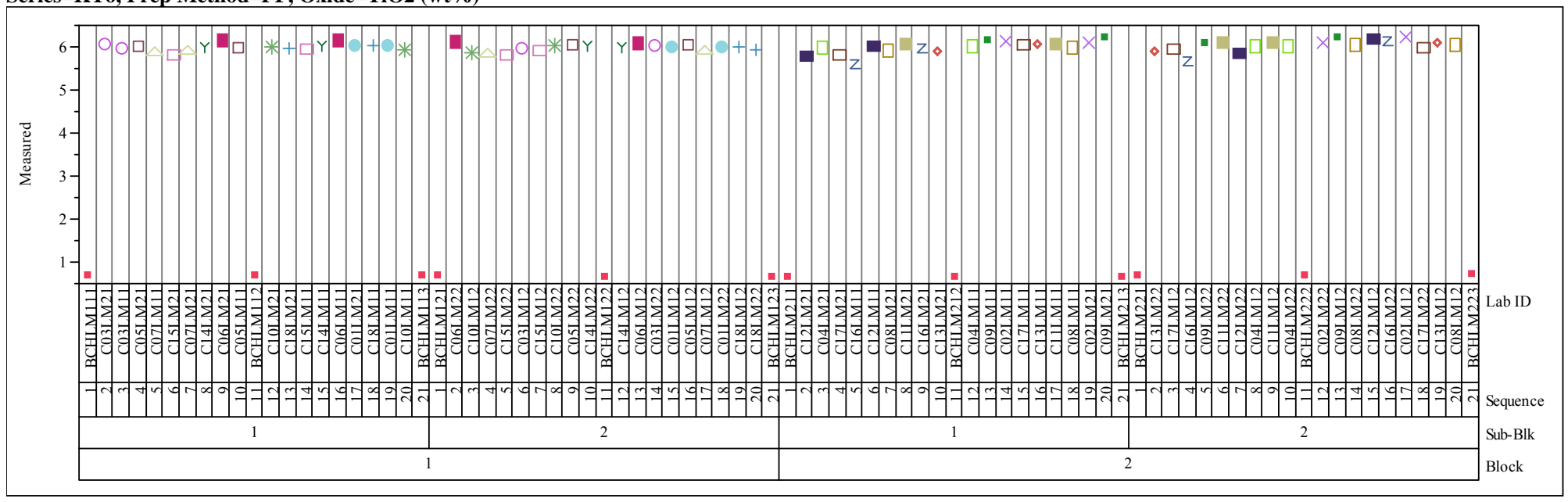


Exhibit A-1. Measurements in Analytical Sequence for the KT06-Series by Preparation Method by Oxide. (continued) Series=KT6, Prep Method=PF, Oxide=ZnO (wt\%)

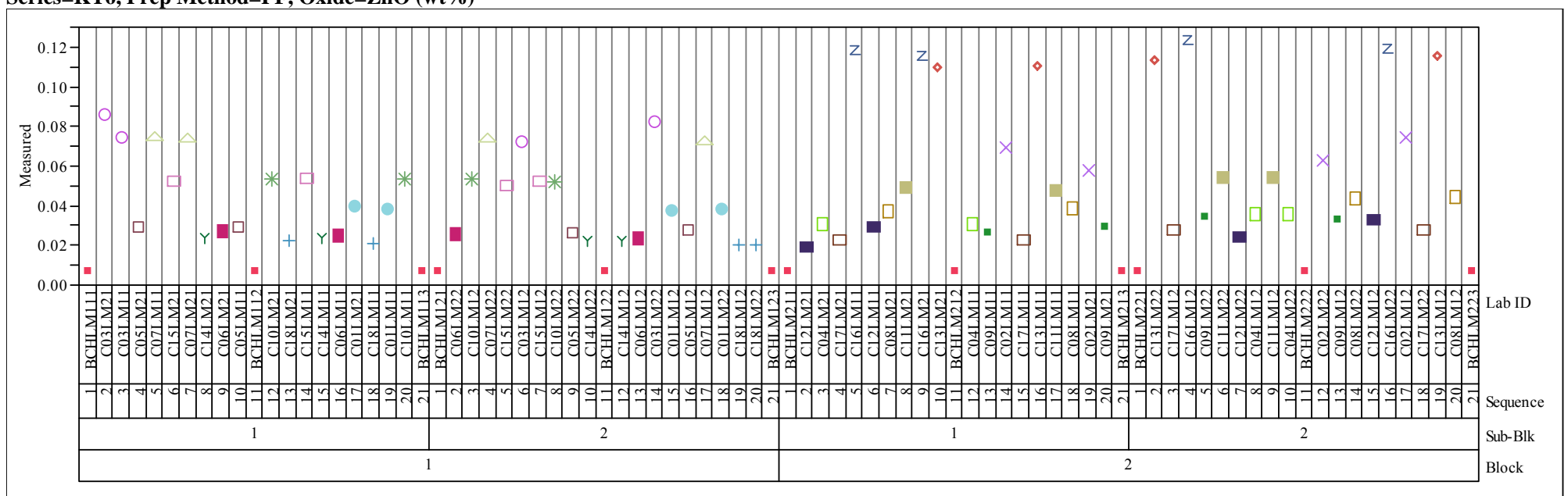

Series=KT6, Prep Method=PF, Oxide=ZrO2 (wt\%)

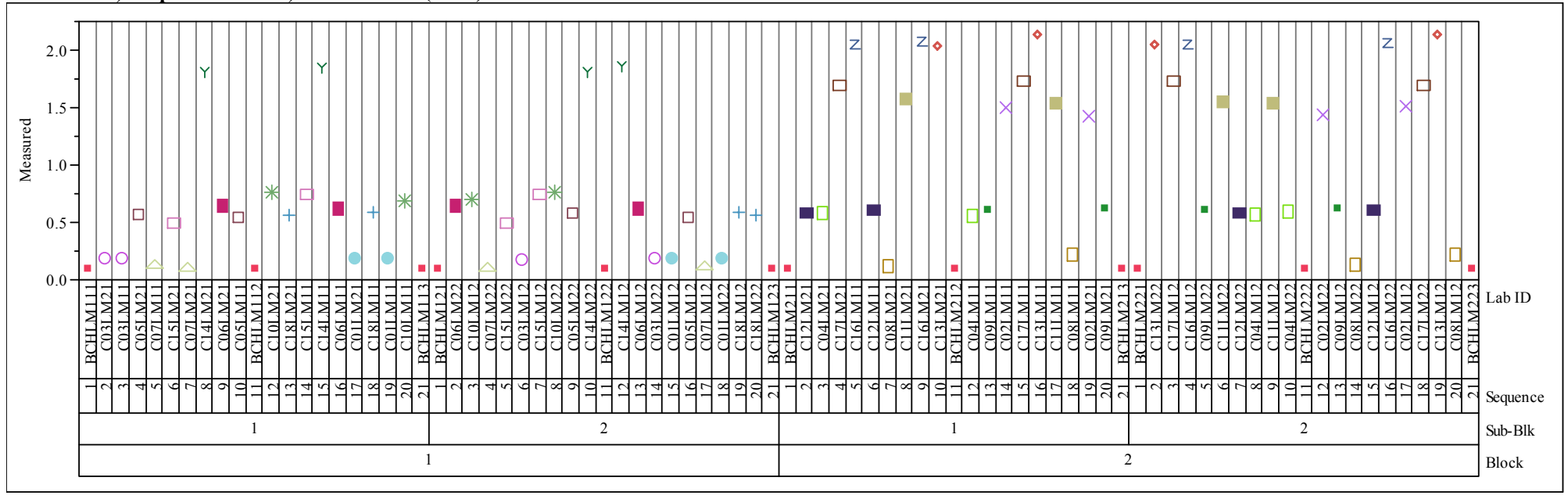




\section{Exhibit A-2. Measurements for Each KT6-Series Glass ID by Preparation Method by Oxide.}

Series=KT6, Prep Method=LM, Oxide=Al2O3 (wt \%)

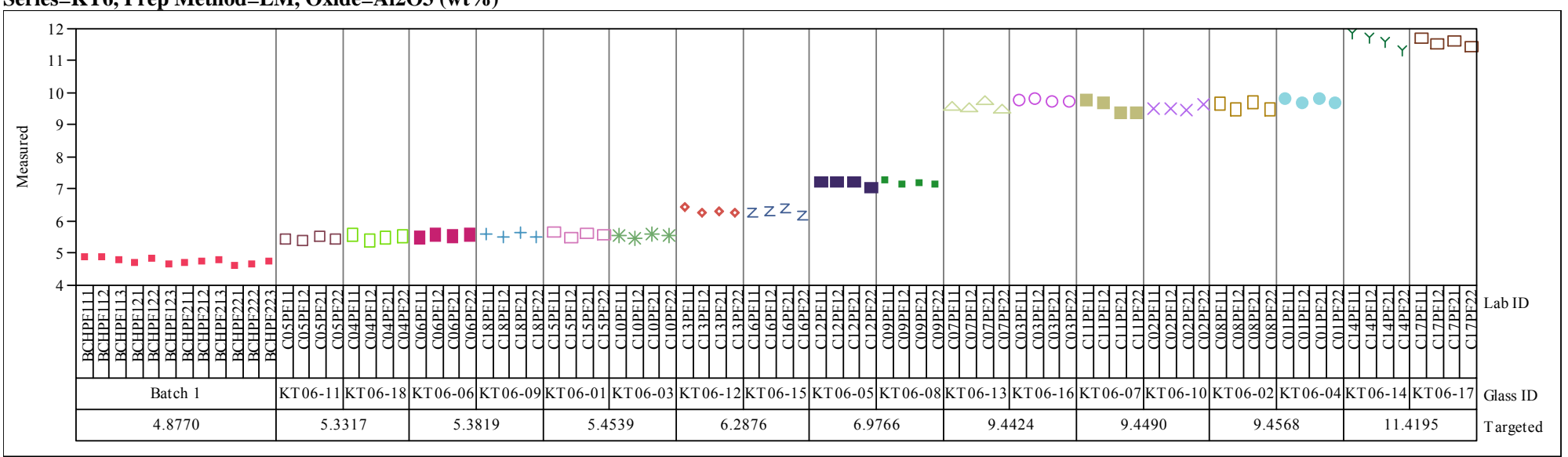

Series=KT6, Prep Method=LM, Oxide=B2O3 (wt\%)

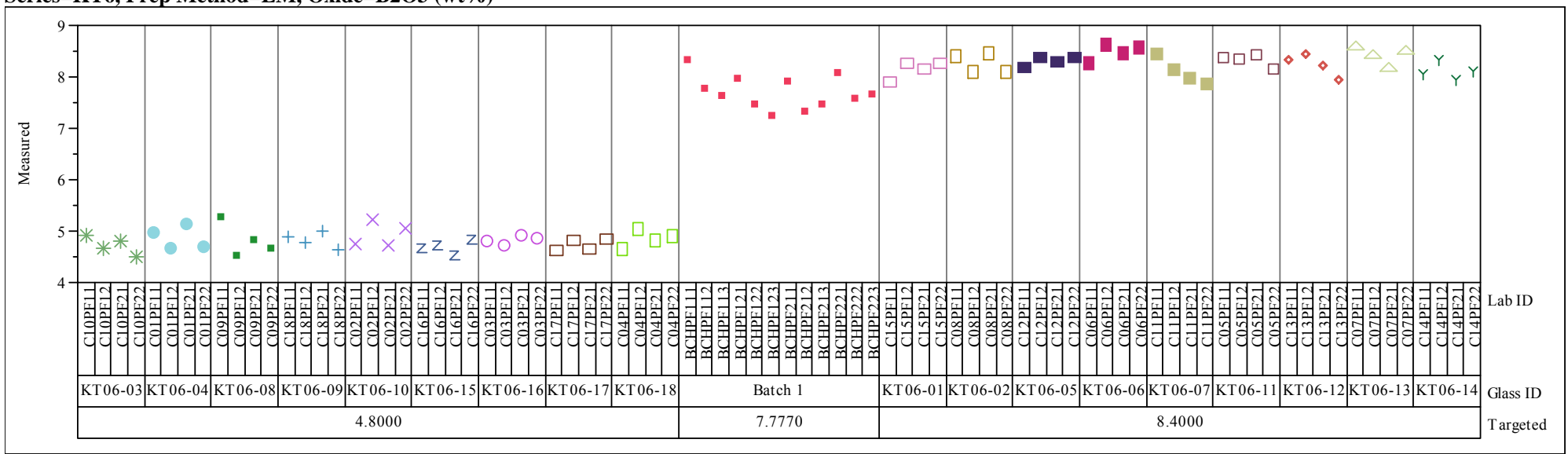


Exhibit A-2. Measurements for Each KT6-Series Glass ID by Preparation Method by Oxide. (continued) Series=KT6, Prep Method=LM, Oxide=Fe2O3 (wt\%)

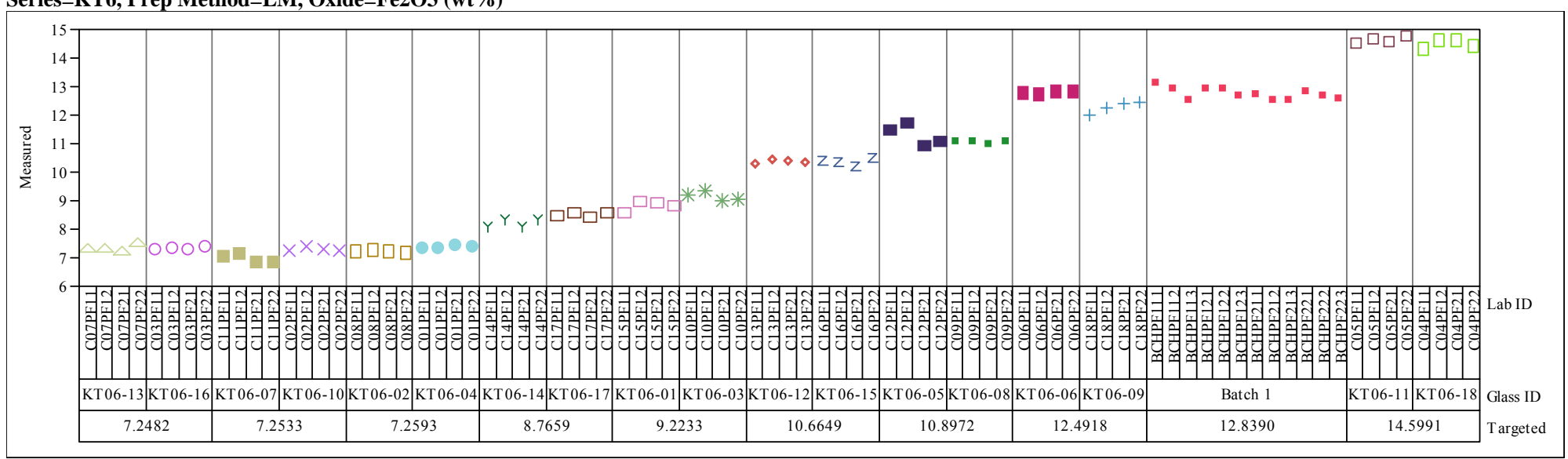

Series=KT6, Prep Method=LM, Oxide=Li2O (wt\%)

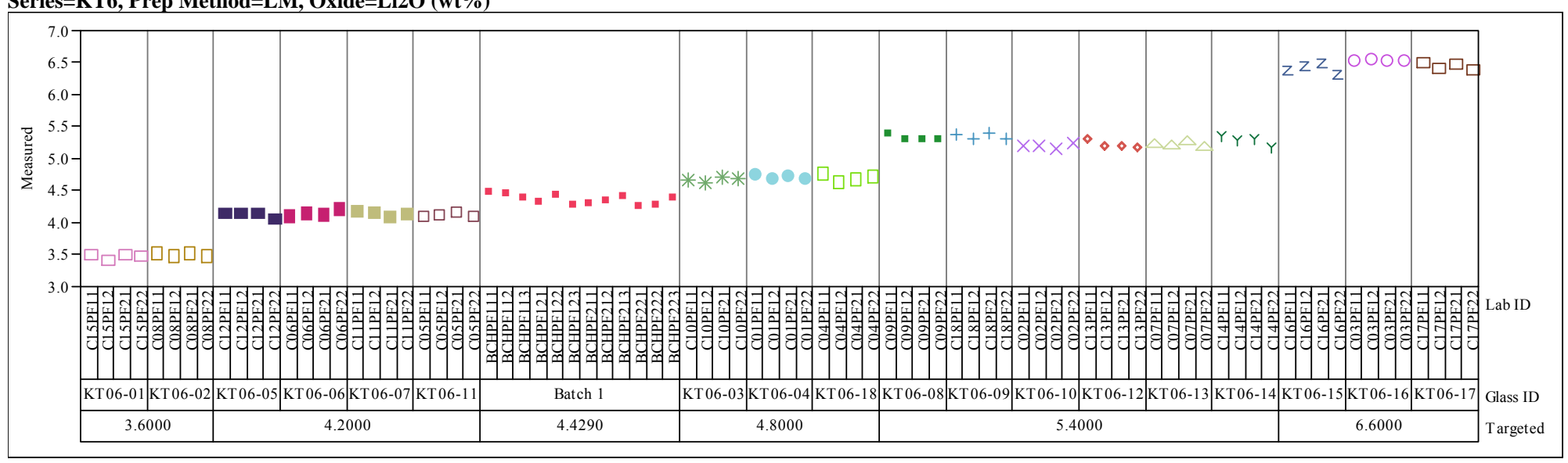


Exhibit A-2. Measurements for Each KT6-Series Glass ID by Preparation Method by Oxide. (continued) Series=KT6, Prep Method=LM, Oxide=SiO2 (wt \%)

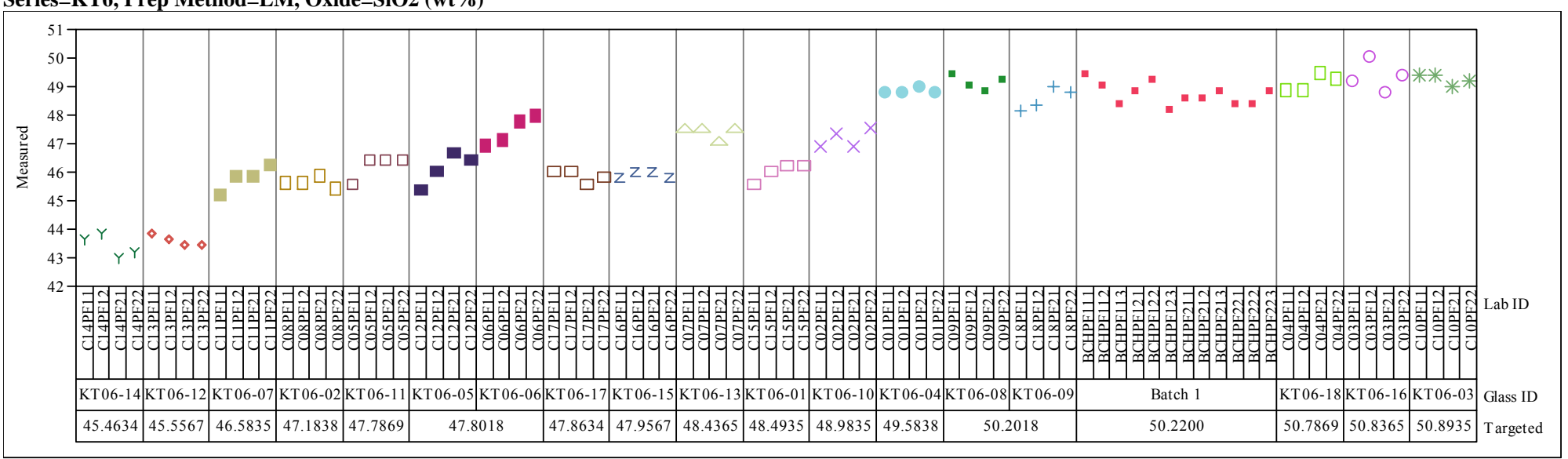

Series=KT6, Prep Method=PF, Oxide=BaO (wt \%)

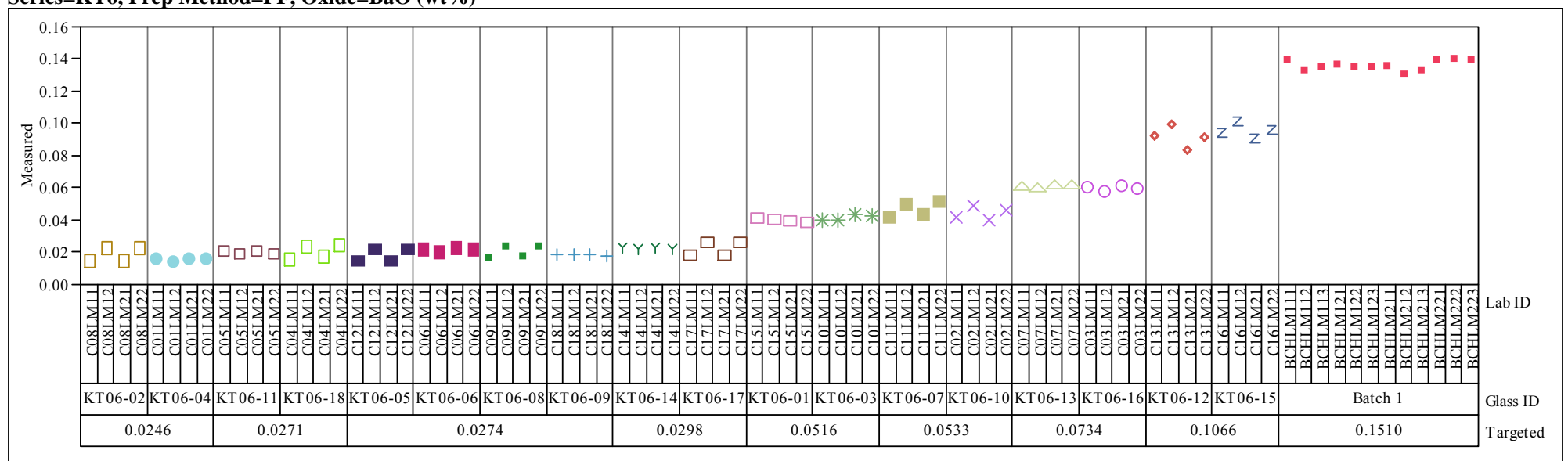


Exhibit A-2. Measurements for Each KT6-Series Glass ID by Preparation Method by Oxide. (continued) Series $=$ KT6, Prep Method $=$ PF, Oxide $=\mathrm{CaO}(w t \%)$

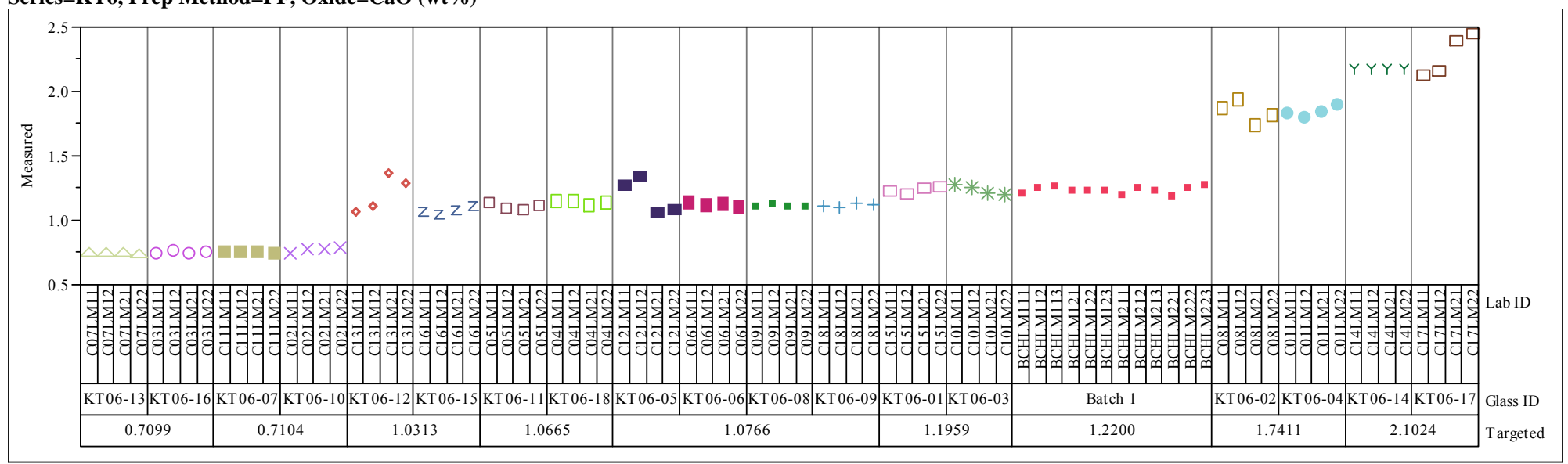

Series=KT6, Prep Method=PF, Oxide=Ce2O3 (wt \%)

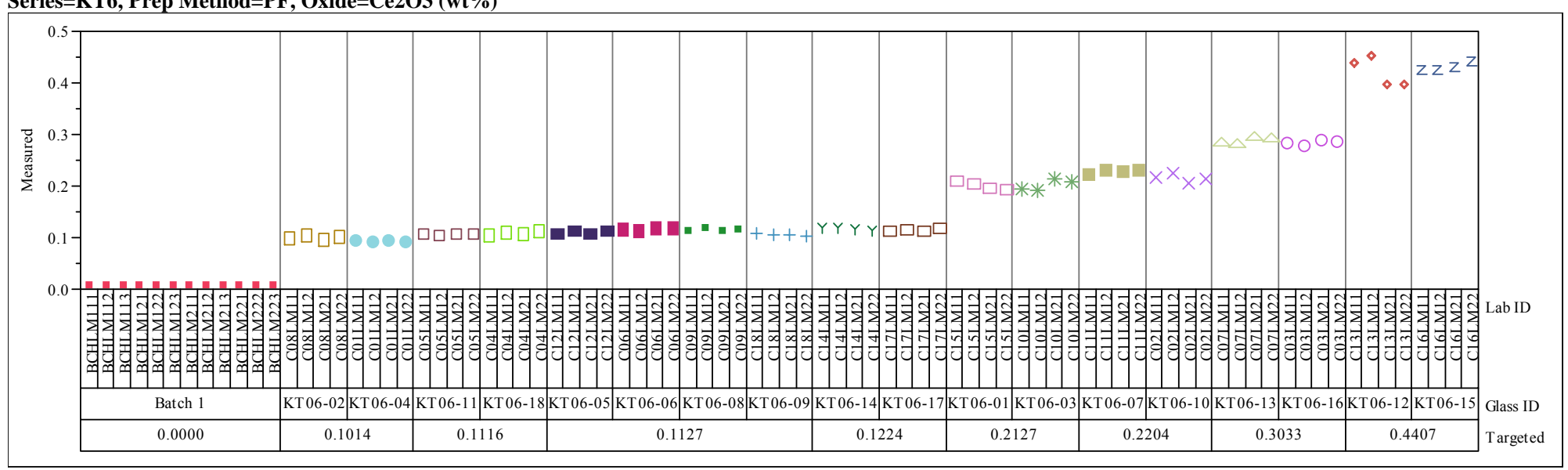


Exhibit A-2. Measurements for Each KT6-Series Glass ID by Preparation Method by Oxide. (continued) Series $=$ KT6, Prep Method $=$ PF, Oxide $=\mathrm{Cr} 2 \mathrm{O} 3(\mathrm{wt} \%)$

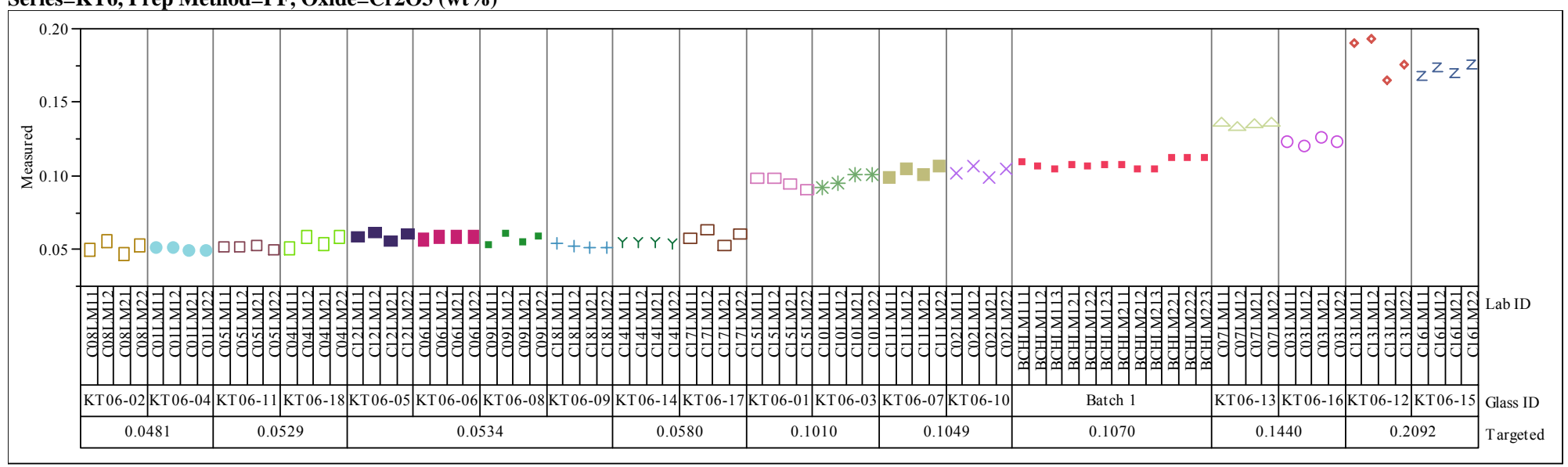

Series=KT6, Prep Method=PF, Oxide=CuO (wt \%)

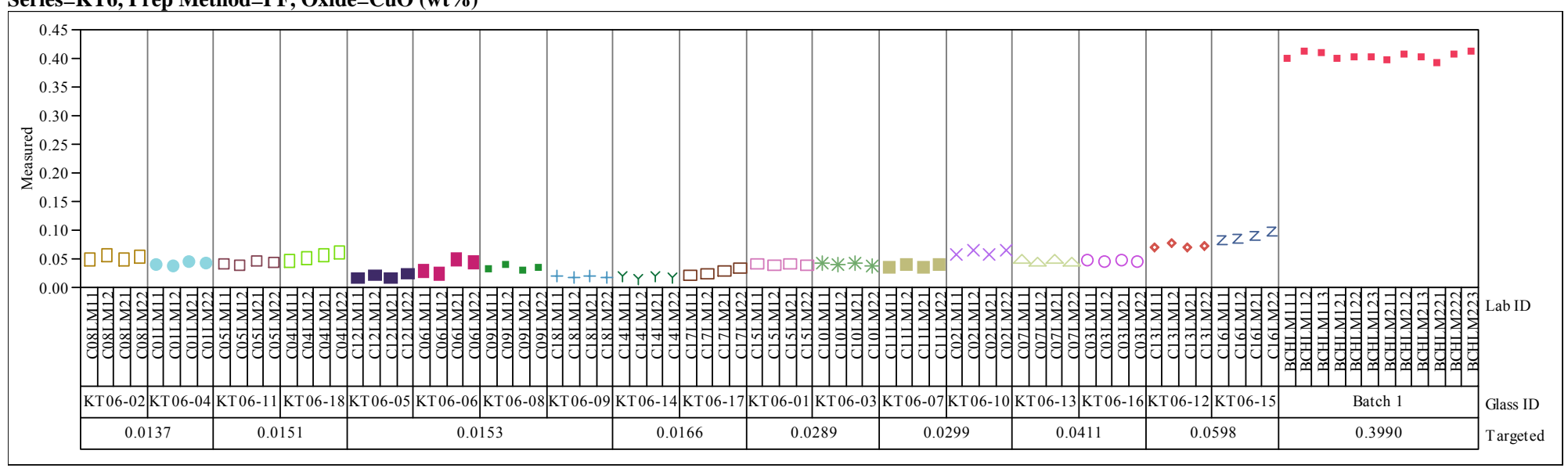


Exhibit A-2. Measurements for Each KT6-Series Glass ID by Preparation Method by Oxide. (continued) Series $=K T 6$, Prep Method $=$ PF, Oxide=K2O (wt \%)

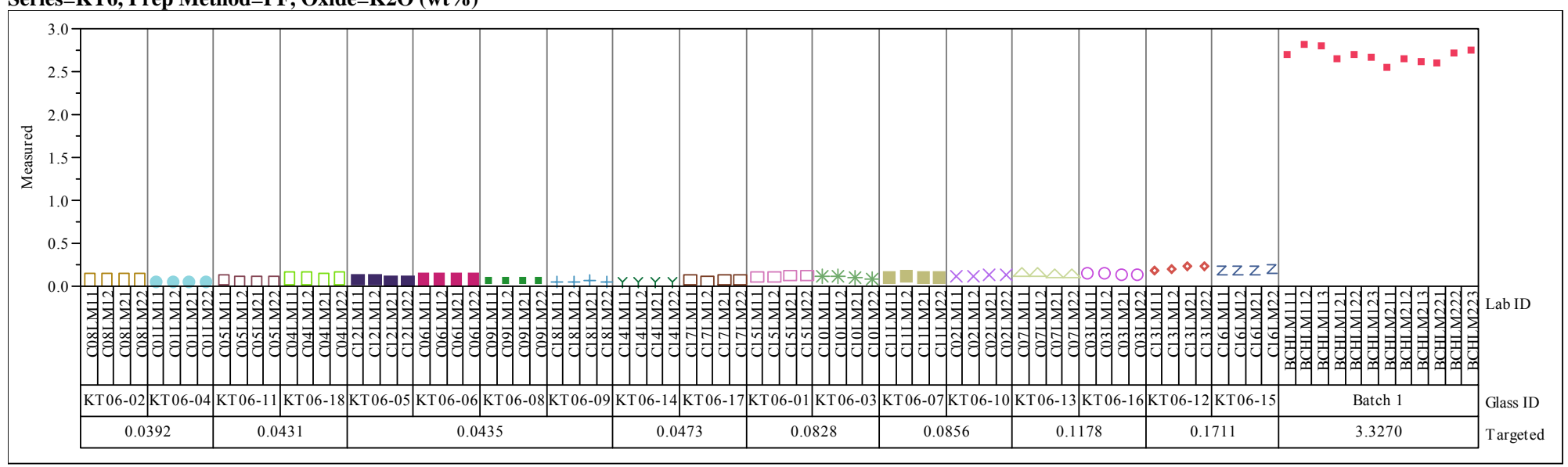

Series=KT6, Prep Method=PF, Oxide=La2O3 (wt \%)

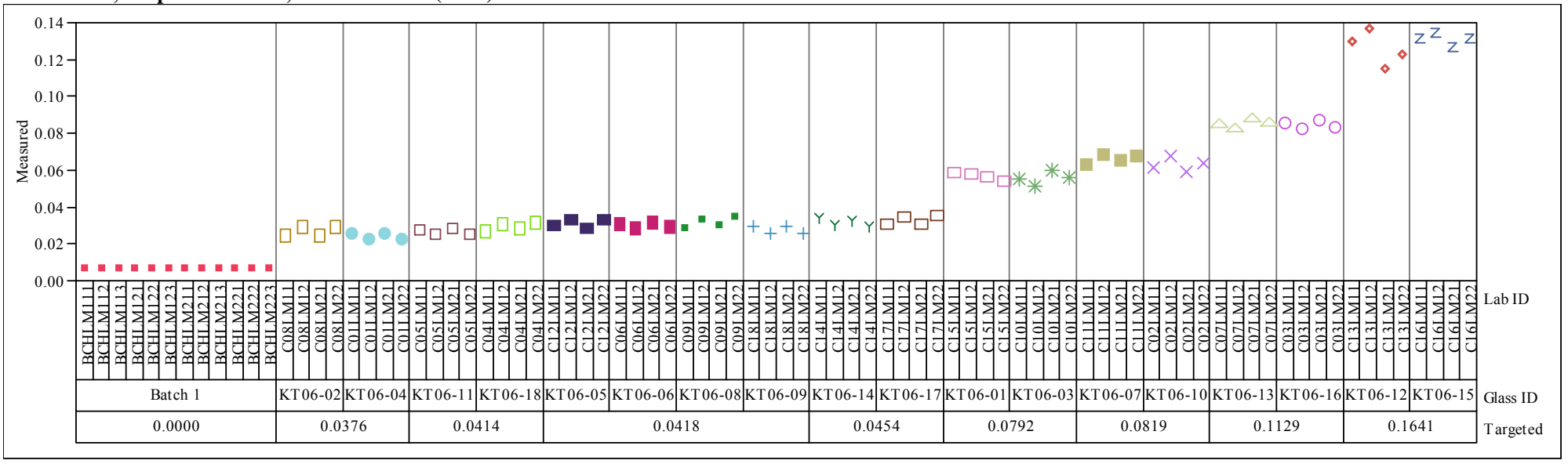


Exhibit A-2. Measurements for Each KT6-Series Glass ID by Preparation Method by Oxide. (continued) Series=KT6, Prep Method=PF, Oxide=MgO (wt\%)

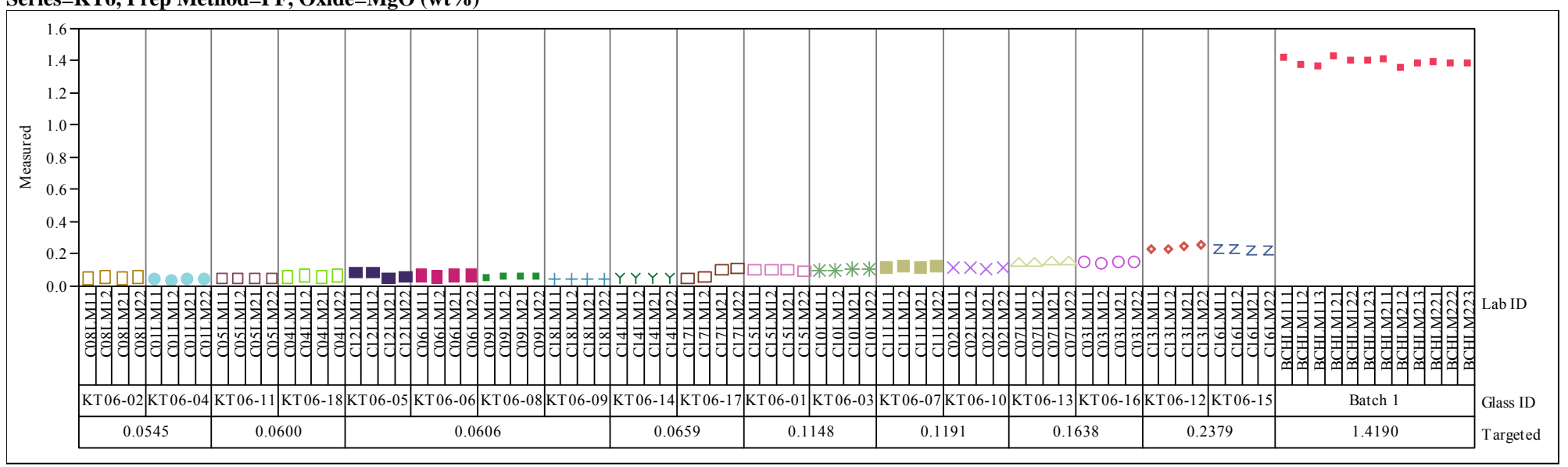

Series=KT6, Prep Method=PF, Oxide=MnO (wt \%)

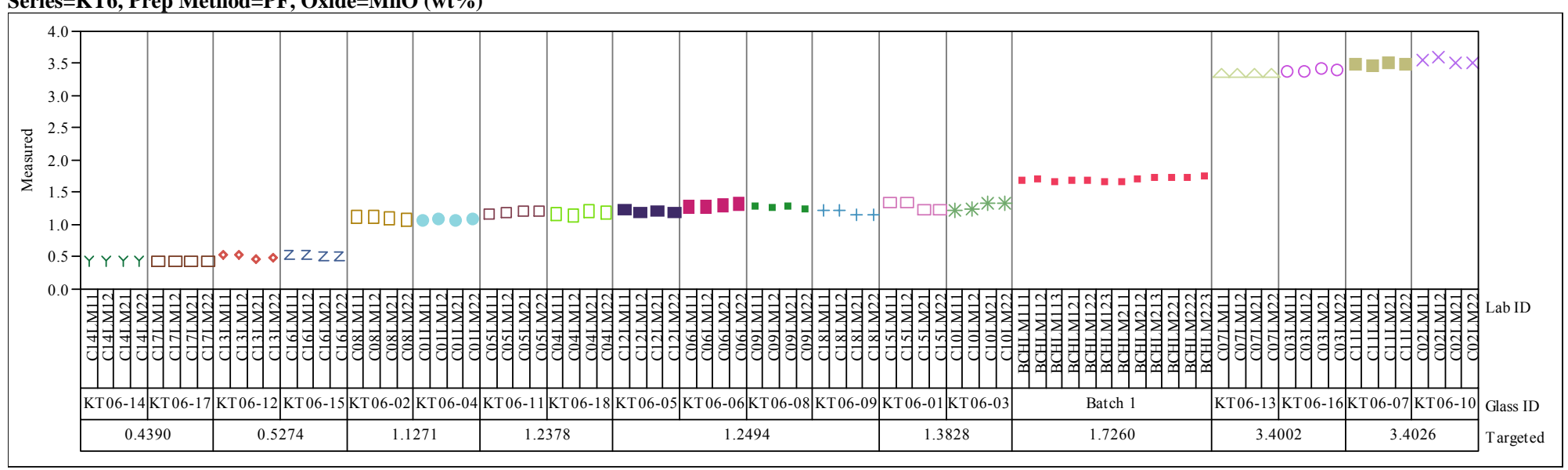


Exhibit A-2. Measurements for Each KT6-Series Glass ID by Preparation Method by Oxide. (continued) Series $=$ KT6, Prep Method=PF, Oxide=Na2O ( $w t \%)$

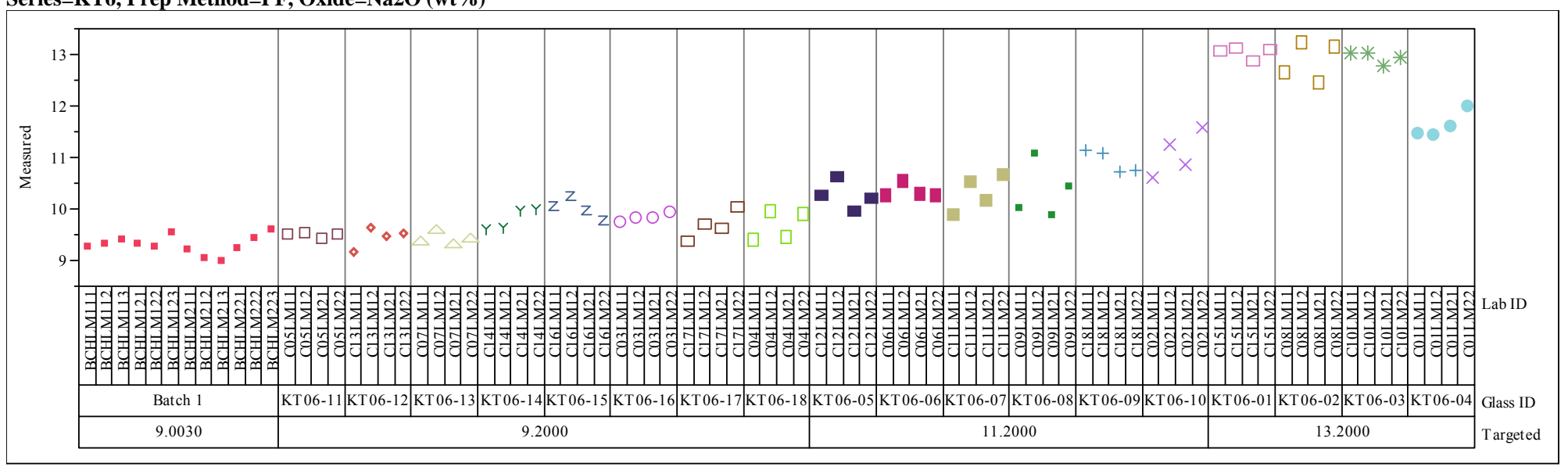

Series=KT6, Prep Method=PF, Oxide=Nb2O5 (wt \%)

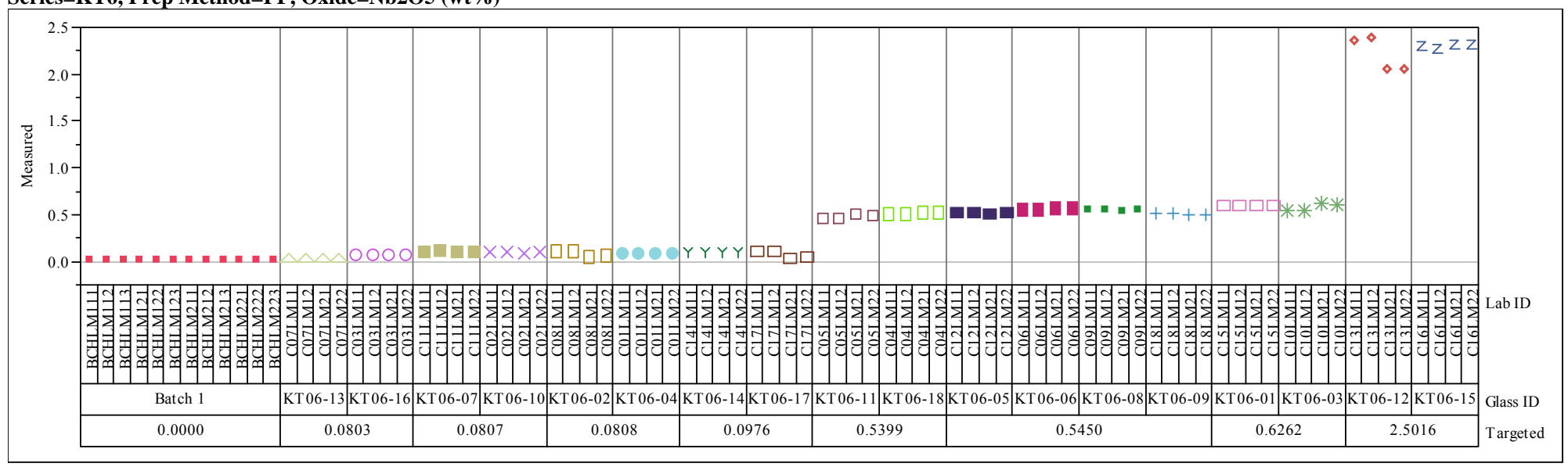


Exhibit A-2. Measurements for Each KT6-Series Glass ID by Preparation Method by Oxide. (continued) Series=KT6, Prep Method=PF, Oxide=NiO ( $w t \%)$

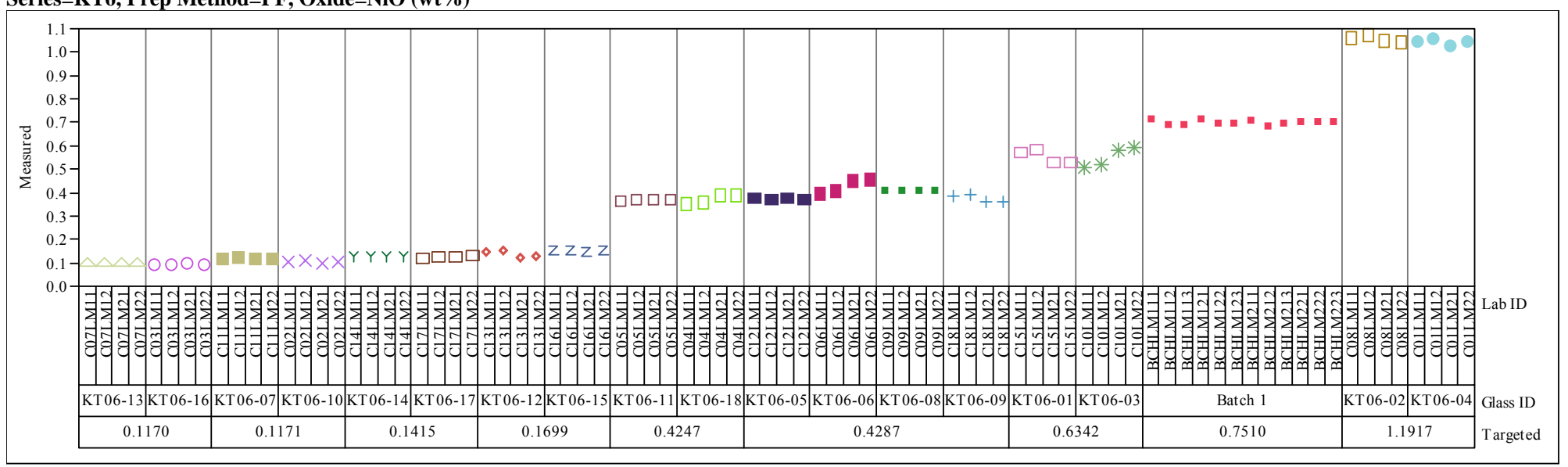

Series=KT6, Prep Method=PF, Oxide=PbO (wt \%)

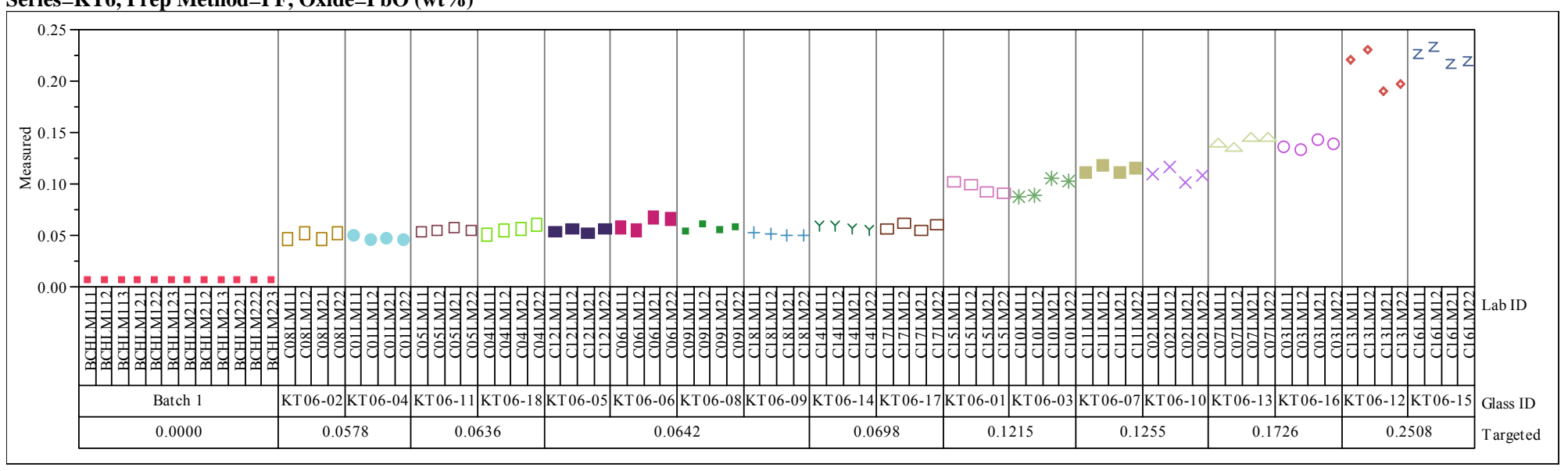


Exhibit A-2. Measurements for Each KT6-Series Glass ID by Preparation Method by Oxide. (continued) Series=KT6, Prep Method=PF, Oxide=SO4 (wt $\%$ )

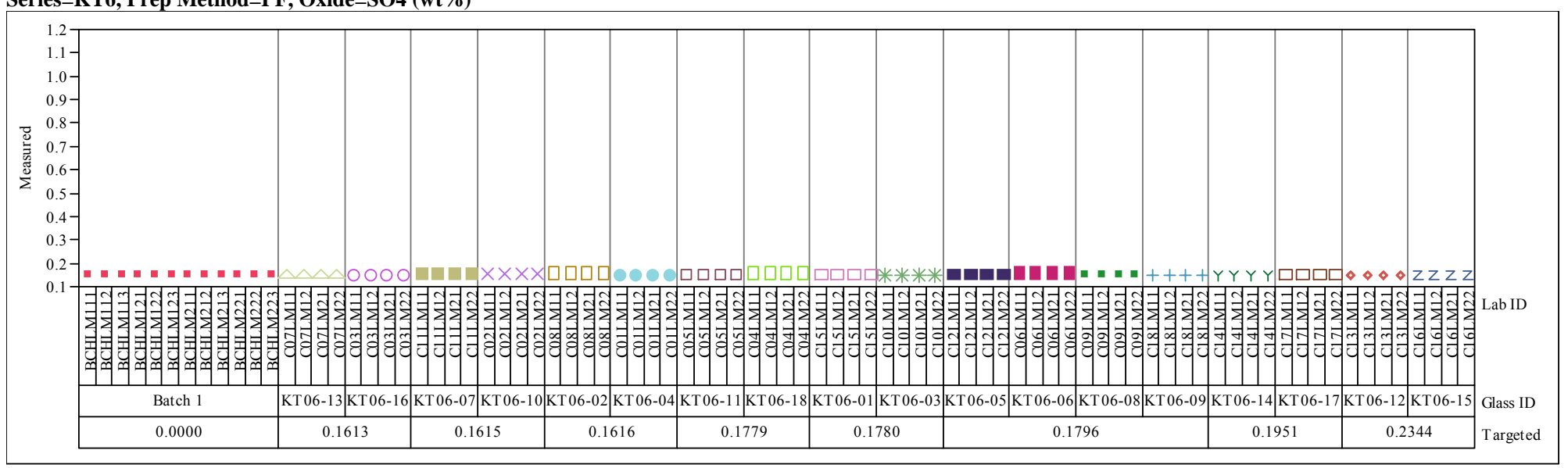

Series=KT6, Prep Method=PF, Oxide=TiO2 (wt \%)

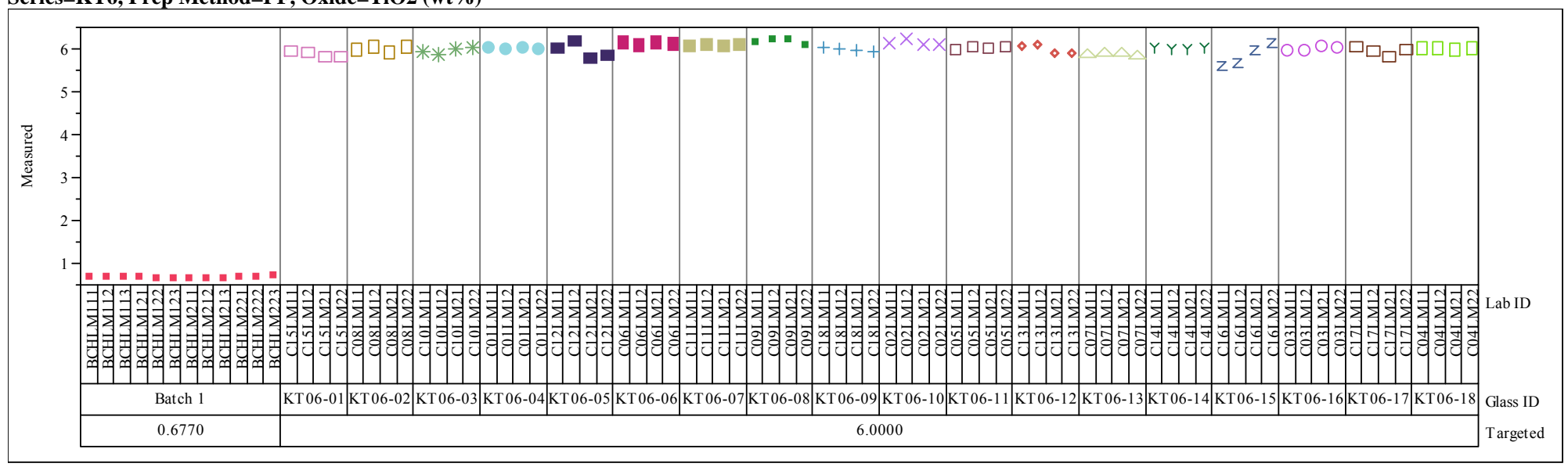


Exhibit A-2. Measurements for Each KT6-Series Glass ID by Preparation Method by Oxide. (continued) Series=KT6, Prep Method=PF, Oxide=ZnO (wt \%)

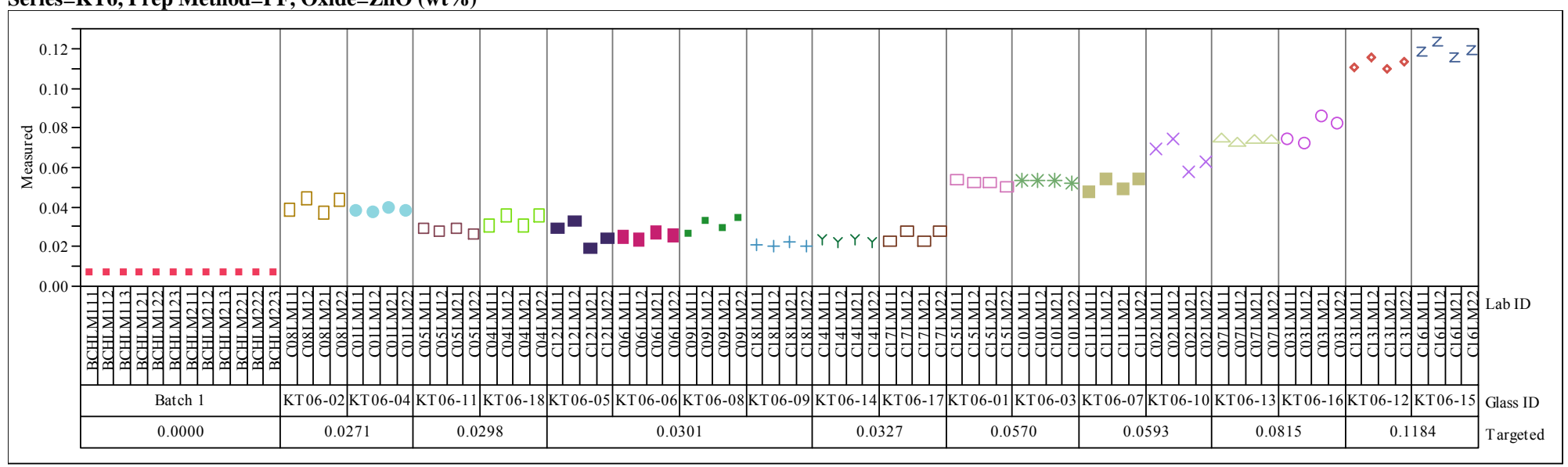

Series=KT6, Prep Method=PF, Oxide=ZrO2 (wt\%)

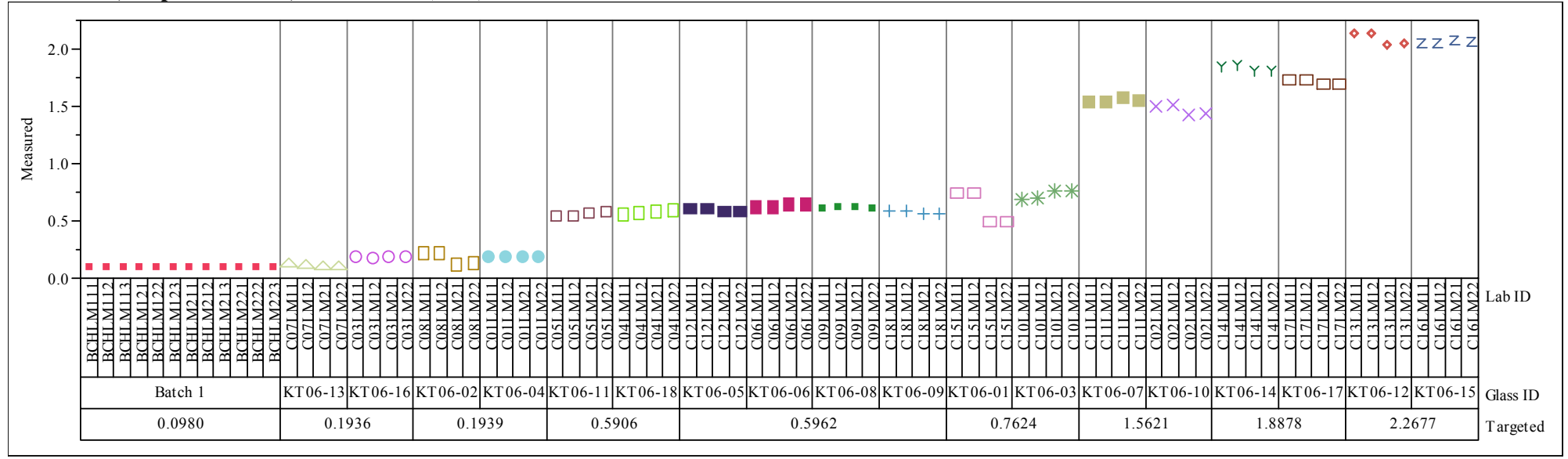


Exhibit A-3. Statistical Evaluation of the ICP-AES Calibration Effects from the KT06 Batch 1 Results by Oxide.

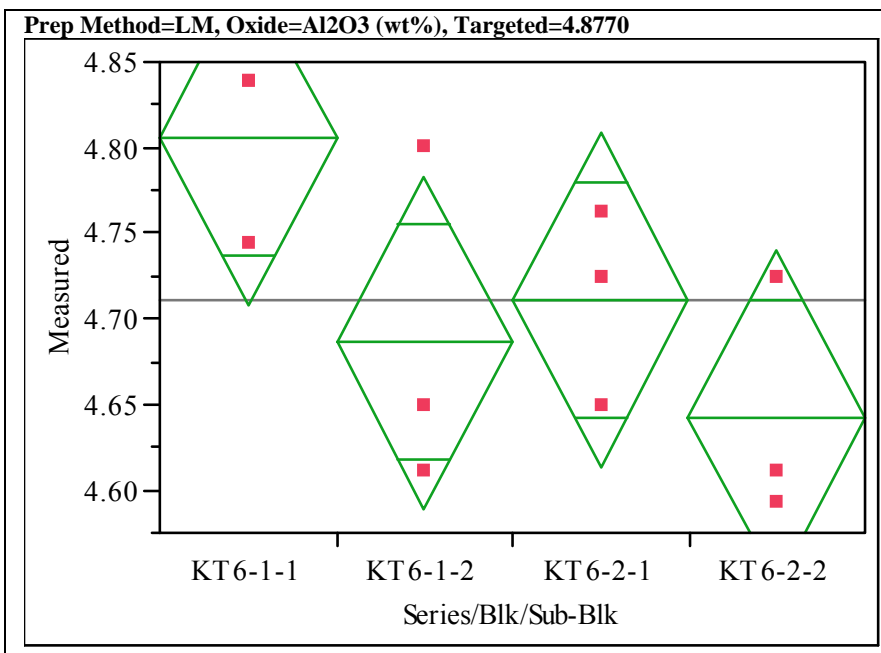

Oneway Anova
Summary of Fit

$\begin{array}{lr}\text { Rsquare } & 0.501385 \\ \text { Adj Rsquare } & 0.314404 \\ \text { Root Mean Square Error } & 0.07318\end{array}$

Root Mean Square Error $\quad 0.07318$
Mean of Response

Mean of Response 4.711153

Analysis of Variance

Source DF Sum of Squares Mean Square F Ratio Prob $>$ F

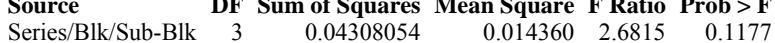

$\begin{array}{lrrr}\text { Series/Blk/Sub-Blk } & 3 & 0.04308054 & 0.014360 \\ \text { Error } & 8 & 0.04284252 & 0.005355\end{array}$

$11 \quad 0.08592306$

Means for Oneway Anova

Level Number Mean Std Error Lower 95\% Upper 95\%

$\begin{array}{lrrrrr}\text { Level } & \text { Number } & \text { Mean } & & & \\ \text { KT6-1 Error } & \text { Lower 95\% } & \text { Upper 95\% } \\ \text { KT6 } & 3 & 4.80563 & 0.04225 & 4.7082 & 4.9031\end{array}$

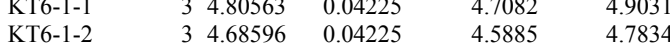

$\begin{array}{llllll}\text { KT6-1-2 } & 3 & 4.68596 & 0.04225 & 4.5885 & 4.7834 \\ \text { KT6-2-1 } & 3 & 4.71115 & 0.04225 & 4.6137 & 4.8086\end{array}$

$\begin{array}{llllll}\text { KT6-2-1 } & 3 & 4.71118 & 0.04225 & 4.6137 & 4.8086 \\ \text { KT6-2-2 } & 3 & 4.64187 & 0.04225 & 4.5444 & 4.7393\end{array}$

Std Error uses a pooled estimate of error variance

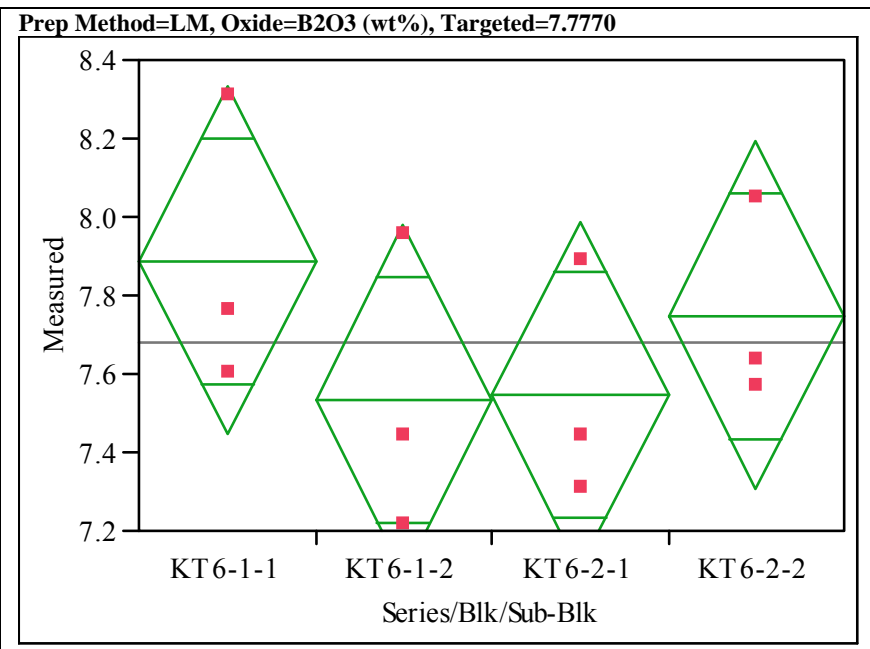

\section{Oneway Anova}

Summary of Fit

Rsquare $\quad 0.228735$

$\begin{array}{ll}\text { Adj Rsquare } & -0.06049 \\ \text { Root Mean Square Error } \quad 0.332939\end{array}$

Root Mean Square Error $\quad 0.332939$

Observations (or Sum Wgts) 7.679462

Analysis of Variance

Source DF Sum of Squares Mean Square F Ratio Prob $>$ F

$\begin{array}{lrrrrr} & \text { DF } & \text { Sum of Squares } & \text { Mean Square } & \text { F Ratio } & \text { Prob }>\text { F } \\ \text { Source } & 3 & 0.2629954 & 0.087665 & 0.7909 & 0.5322\end{array}$

$\begin{array}{lrrr}\text { Error } & 8 & 0.8867887 & 0.110849 \\ \text { C. Total } & 11 & 1.1497841 & \end{array}$

Means for Oneway Anova

Level Number Mean Std Error Lower 95\% Upper 95\%

$\begin{array}{llllll}\text { KT6-1-1 } & 3 & 7.88876 & 0.19222 & 7.4455 & 8.3320\end{array}$

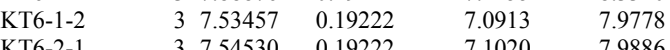

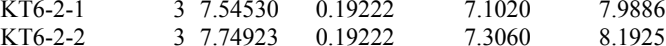

Std Error uses a pooled estimate of error variance 
Exhibit A-3. Statistical Evaluation of the ICP-AES Calibration Effects from the KT06 Batch 1 Results by Oxide. (continued)

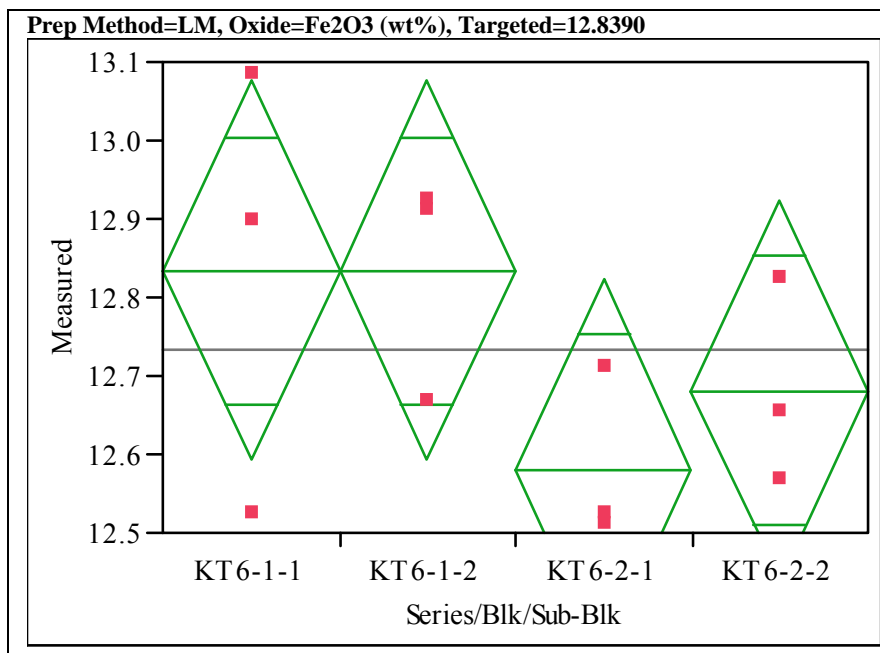

\section{Oneway Anova}

Summary of Fit

Rsquare $\quad 0.344876$

0.099204
Adj Rsquare

Root Mean Square Error $\quad 0.18108$
Mean of Response

$\begin{array}{lr}\text { Observations (or Sum Wgts) } & 12\end{array}$

Analysis of Variance

$\begin{array}{lrrrrr}\text { Source } & \text { DF } & \text { Sum of Squares } & \text { Mean Square } & \text { F Ratio } & \text { Prob }>\text { F } \\ \text { Series/Blk/Sub-Blk } & 3 & 0.13809208 & 0.046031 & 1.4038 & 0.3109\end{array}$

$\begin{array}{lrrr}\text { Series/Blk/Sub-Blk } & 3 & 0.13809208 & 0.046031 \\ \text { Error } & 8 & 0.26231873 & 0.032790 \\ \text { C. Total } & 11 & 0.40041081 & \end{array}$

C. Total

Means for Oneway Anova

Level Number Mean Std Error Lower 95\% Upper 95\%

$\begin{array}{lrrrrr}\text { KT6-1-1 } & 3 & 12.8339 & 0.10455 & 12.593 & 13.075\end{array}$

$\begin{array}{llllll}\text { KT6-1-1 } & 3 & 12.8399 & 0.10455 & 12.593 & 13.075 \\ \text { KT6-1-2 } & 3 & 12.8339 & 0.10455 & 12.593 & 13.075\end{array}$

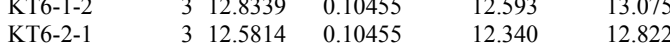

$\begin{array}{llllll}\text { KT6-2-1 } & 3 & 12.5814 & 0.10455 & 12.340 & 12.822 \\ \text { KT6-2-2 } & 3 & 12.6814 & 0.10455 & 12.440 & 12.923\end{array}$

Std Error uses a pooled estimate of error variance

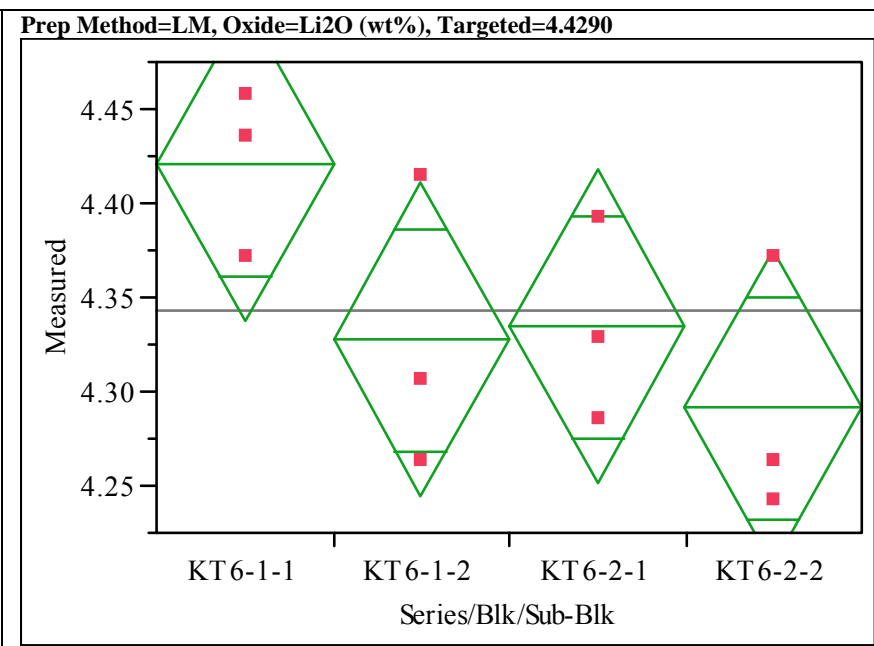

\section{Oneway Anova}

Summary of Fit

$\begin{array}{ll}\text { Rsquare } & 0.461386 \\ \text { Adj Rsquare } & 0.259406\end{array}$

0.259406
Root Mean Square Error $\quad 0.062767$

Root Mean Square Error $\quad 0.062767$

Observations (or Sum Wgts) 4.343476

Analysis of Variance

Source DF Sum of Squares Mean Square F Ratio Prob $>$ F

$\begin{array}{lrrrrr} & & & & \\ \text { Source } & & & & & \\ \text { Series/Blk/Sub-Blk } & 3 & 0.02699875 & 0.009000 & 2.2843 & 0.1558\end{array}$

$\begin{array}{lrrr}\text { Error } & 8 & 0.03151785 & 0.003940\end{array}$

$\begin{array}{lrr}\text { C. Total } & 11 & 0.05851660\end{array}$

\section{Means for Oneway Anova}

Level Number Mean Std Error Lower 95\% Upper 95\%

$\begin{array}{llllll}\text { KT6-1-1 } & 3 & 4.42062 & 0.03624 & 4.3371 & 4.5042\end{array}$

$\begin{array}{llllll}\text { KT6-1-2 } & 3 & 4.32733 & 0.03624 & 4.2438 & 4.4109\end{array}$

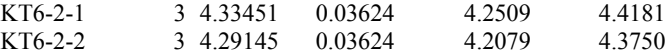

Std Error uses a pooled estimate of error variance 
Exhibit A-3. Statistical Evaluation of the ICP-AES Calibration Effects from the KT06 Batch 1 Results by Oxide. (continued)

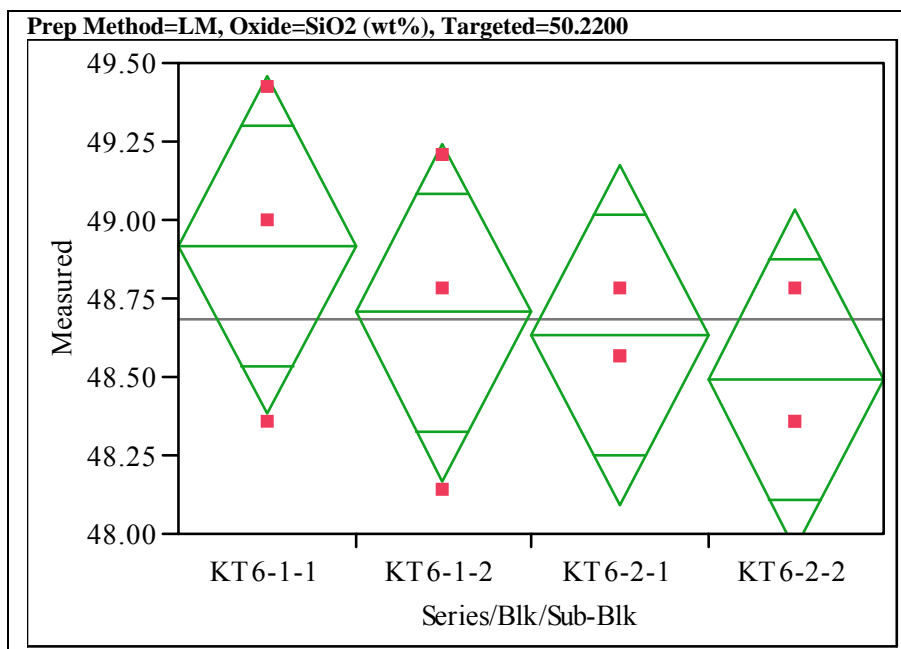

\section{Oneway Anova}

Summary of Fit

Rsquare $\quad 0.178998$

Adj Rsquare $\quad \begin{array}{ll}-0.12888 \\ \text { Root Mean Square Error } \quad 0.404963\end{array}$

Root Mean Square Error $\quad 0.404963$
Mean of Response

Observations (or Sum Wgts) 48.6869

Analysis of Variance

Source DF Sum of Squares Mean Square F Ratio Prob > F

$\begin{array}{lrrrrr}\text { Source } & & & & \\ \text { Series/Blk/Sub-Blk } & 3 & 0.2860378 & 0.095346 & 0.5814 & 0.6436\end{array}$

$\begin{array}{lrrr}\text { Series/Blk/Sub-Blk } & 3 & 0.2860378 & 0.095346 \\ \text { Error } & 8 & 1.3119600 & 0.163995\end{array}$

$\begin{array}{rr}11 & 1.5979977\end{array}$

Means for Oneway Anova

Level Number Mean Std Error Lower 95\% Upper 95\%

$\begin{array}{lrrrrr}\text { KT6-1-1 } & 3 & 48.9187 & 0.23381 & 48.380 & 49.458\end{array}$

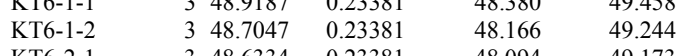

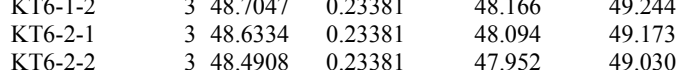

Std Error uses a pooled estimate of error variance

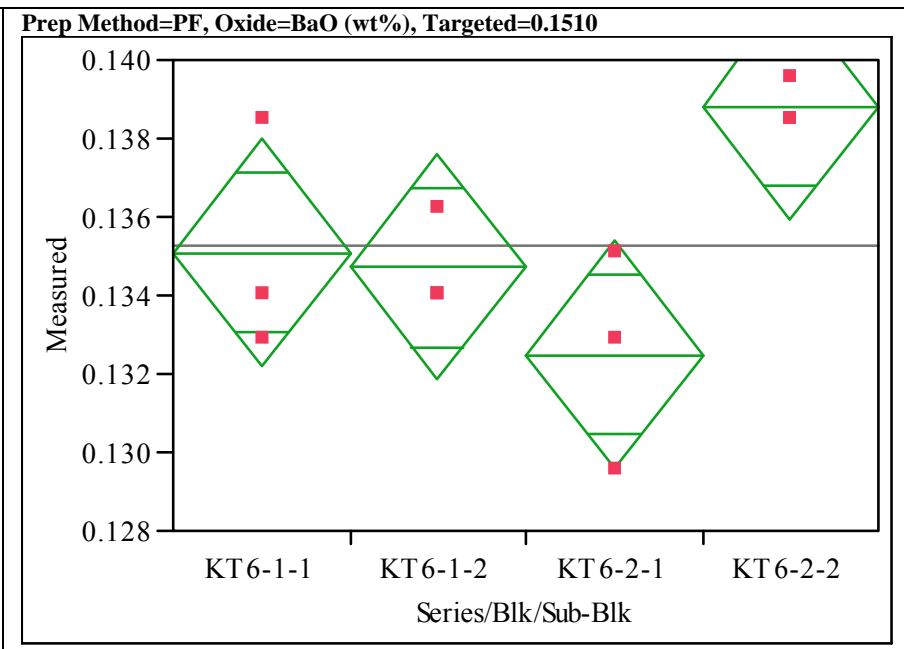

\section{Oneway Anova}

Summary of Fit

$\begin{array}{ll}\text { Rsquare } & 0.623431 \\ \text { Adj } & 0.482218\end{array}$

0.482218
Adj Rsquare

$\begin{array}{lr}\text { Root Mean Square Error } & 0.002162 \\ \text { Mean of Response } & 0.135283\end{array}$

Observations (or Sum Wgts) 12

\section{Analysis of Variance}

Source DF Sum of Squares Mean Square F Ratio Prob $>$ F

$\begin{array}{llllll}\text { Series/Blk/Sub-Blk } & 3 & 0.00006191 & 0.000021 & 4.4148 & 0.0413\end{array}$

$\begin{array}{lrr}\text { Error } & 8 & 0.00003740 \\ \text { C. } & 11 & 0.00009931\end{array}$

$4.675 \mathrm{e}-6$

Means for Oneway Anova

Level Number Mean Std Error Lower 95\% Upper 95\%

\begin{tabular}{lrrrrr}
\hline KT6-1-1 & 3 & 0.135097 & 0.00125 & 0.13222 & 0.13798 \\
\hline
\end{tabular}

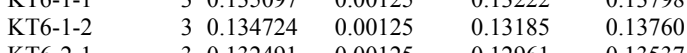

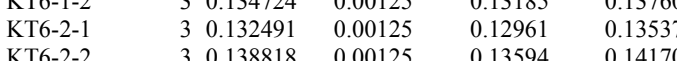

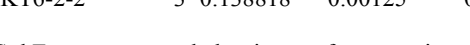

Std Error uses a pooled estimate of error variance 
Exhibit A-3. Statistical Evaluation of the ICP-AES Calibration Effects from the KT06 Batch 1 Results by Oxide. (continued)

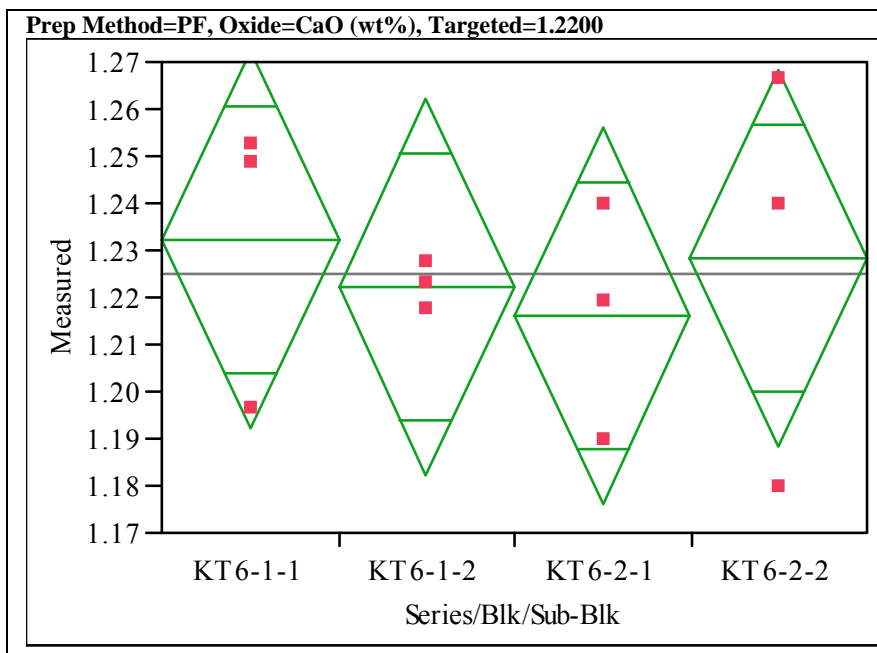

\section{Oneway Anova}

Summary of Fit

Rsquare $\quad 0.059963$

Adj Rsquare $\quad-0.29255$

$\begin{array}{ll}\text { Root Mean Square Error } & 0.030048 \\ \text { Mean of Response } & 1.224766\end{array}$

Observations (or Sum Wgts) 1.224766

Analysis of Variance

Source DF Sum of Squares Mean Square F Ratio Prob $>$ F

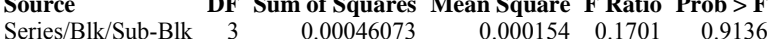

$\begin{array}{llll}\text { Series/Blk/Sub-Blk } & 3 & 0.00046073 & 0.000154 \\ \text { Error } & 8 & 0.00722283 & 0.000903\end{array}$

C. Tota

$11 \quad 0.00768356$

Means for Oneway Anova

Level Number Mean Std Error Lower 95\% Upper 95\%

$\begin{array}{lrrrrr}\text { LT6-1-1 } & 3 & 1.23223 & 0.01735 & 1.1922 & 1.2722 \\ \text { KT-1- } & 3 & 1.22243 & 0.01735 & 1.1824 & 1.2624 \\ \text { KT6-1-2 } & 3 & 1.2159 & 0.0175 & 1.175 & 1.2559\end{array}$

\begin{tabular}{llllll} 
KT6-1-2 & 3 & 1.22243 & 0.01735 & 1.1824 & 1.2624 \\
KT6-2-1 & 3 & 1.21590 & 0.01735 & 1.1759 & 1.2559 \\
\hline
\end{tabular}

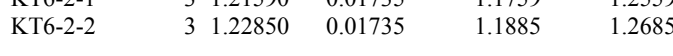

Std Error uses a pooled estimate of error variance

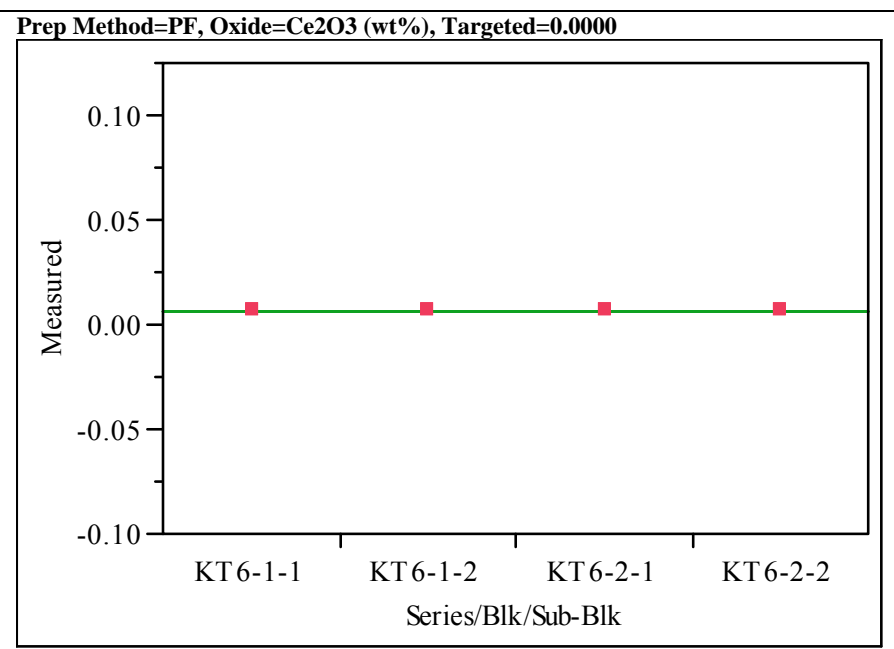

\section{Oneway Anova}

Summary of Fit

\section{Rsquare}

\section{Adj Rsquare}

$\begin{array}{lr}\text { Root Mean Square Error } & 0 \\ \text { Mean of Response } & 0.005857\end{array}$

0.005857

Analysis of Variance

Source DF Sum of Squares Mean Square F Ratio Prob > F

$\begin{array}{lrrr}\text { Source } & \text { DF } & \text { Sum of Squares } & \text { Mean Square } \\ \text { Series/Blk/Sub-Blk } & 3 & 0 & 0 \\ \text { Error } & 8 & 0 & 0 \\ \text { C. } & 1 & 0 & \end{array}$

$\begin{array}{lrr}\text { Error } & 8 & 0 \\ \text { C. Total } & 11 & 0\end{array}$

Means for Oneway Anova

Level Number Mean Std Error Lower 95\% Upper 95\%

$\begin{array}{lrrrrr}\text { KT6-1-1 } & 3 & 0.005857 & 0 & 0.00586 & 0.00586 \\ \text { KT6-1-2 } & 3 & 0.005857 & 0 & 0.00586 & 0.00586\end{array}$

$\begin{array}{llllll}\text { KT6-1-1 } & 3 & 0.005857 & 0 & 0.00586 & 0.00586 \\ \text { KT6-1-2 } & 3 & 0.005857 & 0 & 0.00586 & 0.00586 \\ \text { KT6-2-1 } & 3 & 0.005857 & 0 & 0.00586 & 0.00586\end{array}$

$\begin{array}{llllll}\text { KT6-2-1 } & 3 & 0.005857 & 0 & 0.00586 & 0.00586 \\ \text { KT6-2-2 } & 3 & 0.005857 & 0 & 0.00586 & 0.00586\end{array}$

Std Error uses a pooled estimate of error variance 
Exhibit A-3. Statistical Evaluation of the ICP-AES Calibration Effects from the KT06 Batch 1 Results by Oxide. (continued)

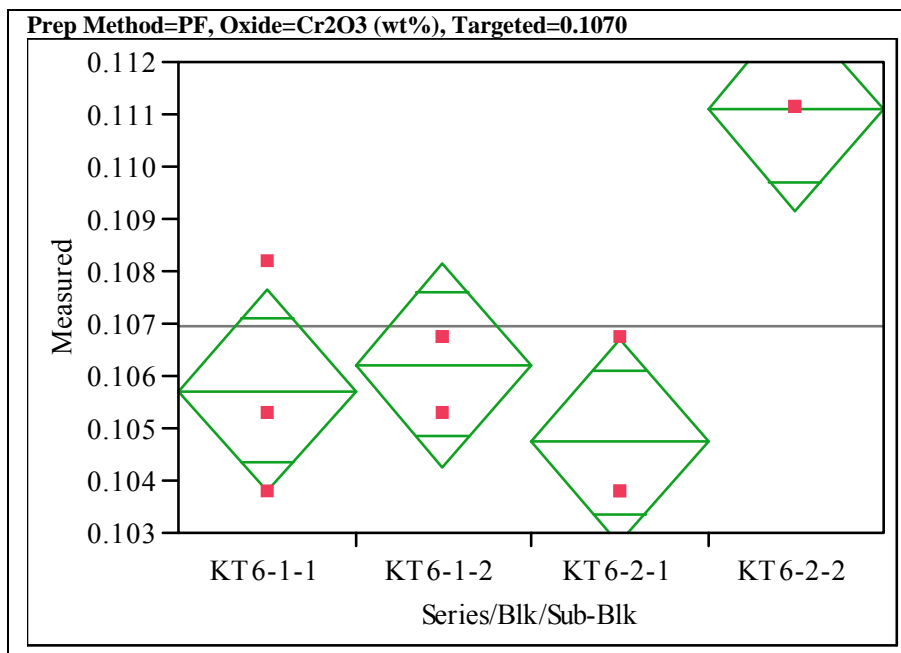

\section{Oneway Anova}

Summary of Fit

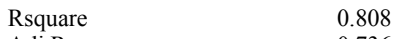

Rsquare

0.808

$\begin{array}{lr}\text { Adj Rsquare } & 0.736 \\ \text { Root Mean Square Error } \quad 0.001462\end{array}$

Root Mean Square Error $\quad 0.001462$

Mean of Response 0.10694

Analysis of Variance

Source DF Sum of Squares Mean Square F Ratio Prob $>$ F

$\begin{array}{lrrrrr}\text { Source } & \text { DF } & \text { Sum of Squares } & \text { Mean Square } & \text { F Ratio } & \text { Prob }>\text { F } \\ \text { Series/Blk/Sub-Blk } & 3 & 0.00007192 & 0.000024 & 11.2222 & 0.0031\end{array}$

$\begin{array}{lrrr}\text { Series/Blk/Sub-Blk } & 3 & 0.00007192 & 0.000024 \\ \text { Error } & 8 & 0.00001709 & 2.136 \mathrm{e}-6 \\ \text { C. Total } & 11 & 0.00008901 & \end{array}$

C. Tota

Means for Oneway Anova

Level Number Mean Std Error Lower 95\% Upper 95\%

\begin{tabular}{lrrrrr}
\hline KT6-1-1 & 3 & 0.105722 & 0.00084 & 0.10378 & 0.10767
\end{tabular}

$\begin{array}{llllll}\text { KT6-1-1 } & 3 & 0.105722 & 0.00084 & 0.10378 & 0.10767 \\ \text { KT6-1-2 } & 3 & 0.106210 & 0.00084 & 0.10426 & 0.10816\end{array}$

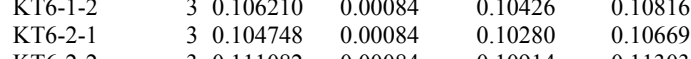

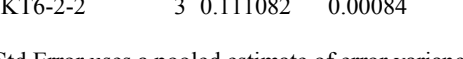

Prep Method=PF, Oxide=CuO (wt \%), Targeted $=0.3990$

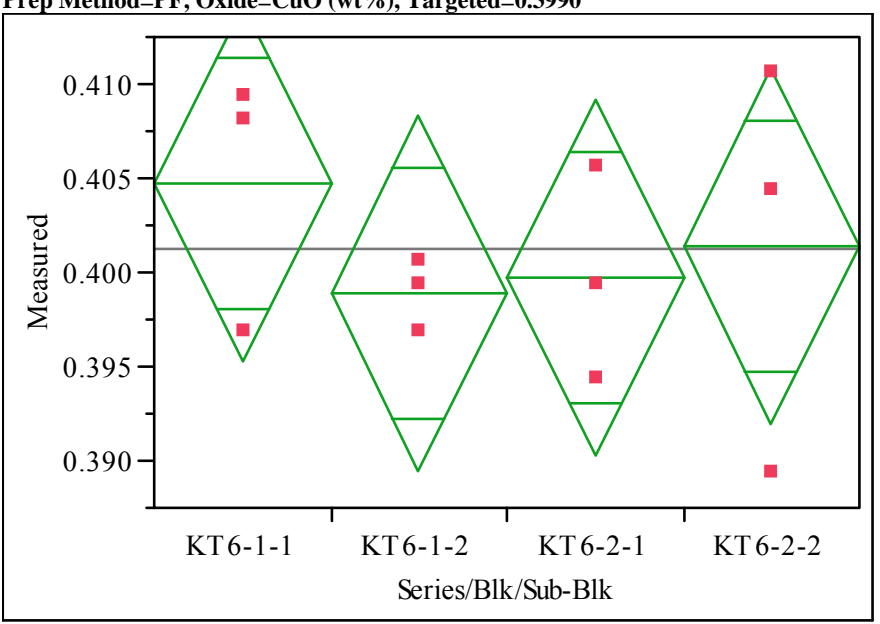

\section{Oneway Anova}

Summary of Fit

$\begin{array}{ll}\text { Rsquare } & 0.129068 \\ \text { Adj Rsquare } & 0.19753\end{array}$

$\begin{array}{ll} & -0.19753 \\ \text { Root Mean Square Error } \quad 0.007118\end{array}$

Root Mean Square Error $\quad 0.007118$

Observations (or Sum Wgts)

Analysis of Variance

Source DF Sum of Squares Mean Square F Ratio Prob $>$ F

$\begin{array}{lrrrrr}\text { Source } & \text { DF } & \text { Sum of Squares } & \text { Mean Square } & & \\ \text { Series/Blk/Sub-Blk } & 3 & 0.00006007 & 0.000020 & 0.3952 & 0.7601\end{array}$

$\begin{array}{llll}\text { Error } & 8 & 0.00040533 & 0.000051\end{array}$

$\begin{array}{lrr}\text { C. Total } & 11 & 0.00046540\end{array}$

Means for Oneway Anova

Level Number Mean Std Error Lower 95\% Upper 95\%

\begin{tabular}{lrrrrr}
\hline KT6-1-1 & 3 & 0.404749 & 0.00411 & 0.39527 & 0.41423 \\
\hline
\end{tabular}

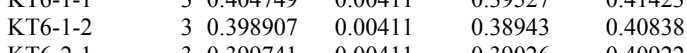

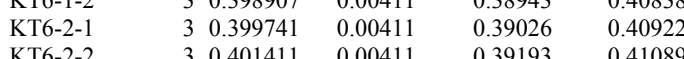

Std Error uses a pooled estimate of error variance 
Exhibit A-3. Statistical Evaluation of the ICP-AES Calibration Effects from the KT06 Batch 1 Results by Oxide. (continued)

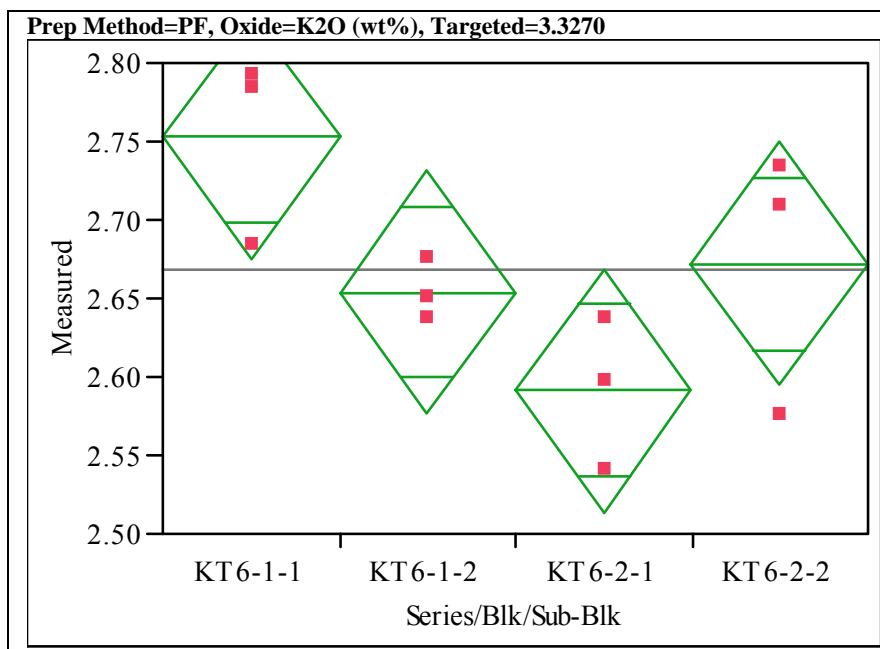

\section{Oneway Anova}

Summary of Fit

$\begin{array}{ll}\text { Rsquare } & 0.595687 \\ \text { Adj Rsquare } & 0.444069\end{array}$

0.444069
Root Mean Square Error $\quad 0.058122$

Root Mean Square Error $\quad 0.058122$
Mean of Response

Mean of Response 2.66768

Analysis of Variance

$\begin{array}{lrrrrr}\text { Source } & \text { DF } & \text { Sum of Squares } & \text { Mean Square } & \text { F Ratio } & \text { Prob }>\text { F } \\ \text { Series/Blk/Sub-Blk } & 3 & 0.03981748 & 0.013272 & 3.9289 & 0.0540\end{array}$

$\begin{array}{lccc}\text { Series/Blk/Sub-Blk } & 3 & 0.03981748 & 0.013272 \\ \text { Error } & 8 & 0.02702553 & 0.003378\end{array}$

C. Total

$11 \quad 0.06684301$

0.003378

Means for Oneway Anova

Level Number Mean Std Error Lower 95\% Upper 95\%

\begin{tabular}{lrrrrr} 
Level & Number & Mean & Std Error & Lower 95\% & Upper 95\% \\
KT6-1-1 & 3 & 2.75291 & 0.03356 & 2.6755 & 2.8303 \\
\hline
\end{tabular}

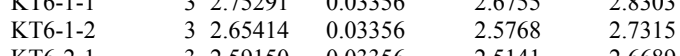

\begin{tabular}{llllll} 
KT6-1-2 & 3 & 2.65414 & 0.03356 & 2.5768 & 2.7315 \\
KT6-2-1 & 3 & 2.59150 & 0.03356 & 2.5141 & 2.6689 \\
\hline
\end{tabular}

$\begin{array}{llll}\text { KT6-2-2 } & 32.67220 & 0.03356 & 2.5948\end{array}$

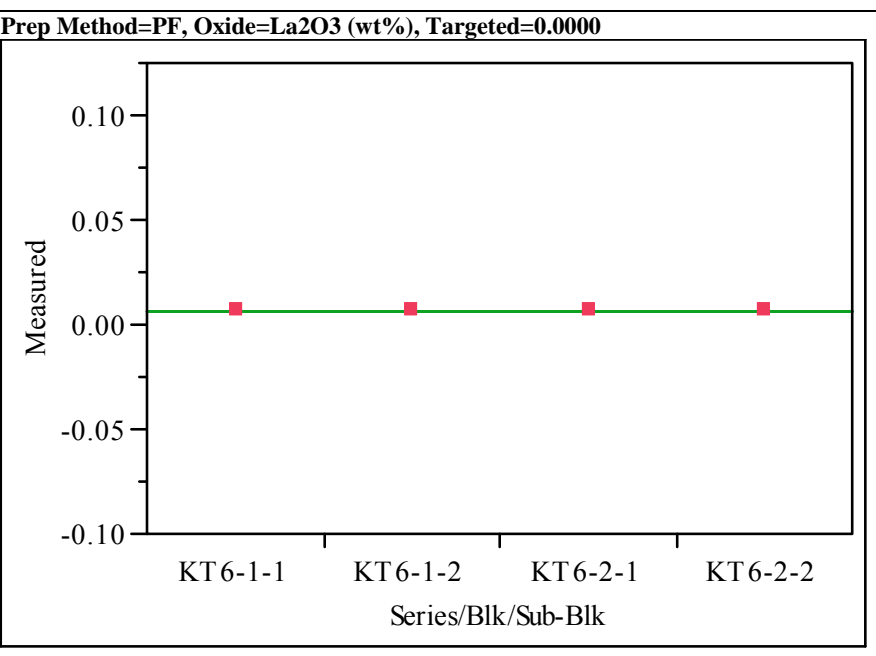

\section{Oneway Anova}

Summary of Fit

Rsquare

Adj Rsquare

Root Mean Square Error $\quad 0$

Mean of Response $\quad 0.005864$

Observations (or Sum Wgts) $\quad 12$

Analysis of Variance

Source DF Sum of Squares Mean Square F Ratio Prob > F

$\begin{array}{lrrr}\text { Series/Blk/Sub-Blk } & 3 & 0 & 0 \\ \text { Error } & 8 & 0 & 0 \\ \text { C } & 1 & 0 & \end{array}$

$\begin{array}{lrr}\text { Error } & 8 & 0 \\ \text { C. Total } & 11 & 0\end{array}$

Means for Oneway Anova

Level Number Mean Std Error Lower 95\% Upper 95\%

\begin{tabular}{lrrrrr} 
KT6-1-1 & 3 & 0.005864 & 0 & 0.00586 & 0.00586 \\
\hline
\end{tabular}

$\begin{array}{llllll}\text { KT6-1-1 } & 3 & 0.005864 & 0 & 0.00586 & 0.00586 \\ \text { KT6-1-2 } & 3 & 0.005864 & 0 & 0.00586 & 0.00586\end{array}$

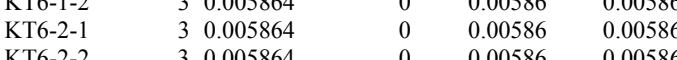

Std Error uses a pooled estimate of error variance 
Exhibit A-3. Statistical Evaluation of the ICP-AES Calibration Effects from the KT06 Batch 1 Results by Oxide. (continued)

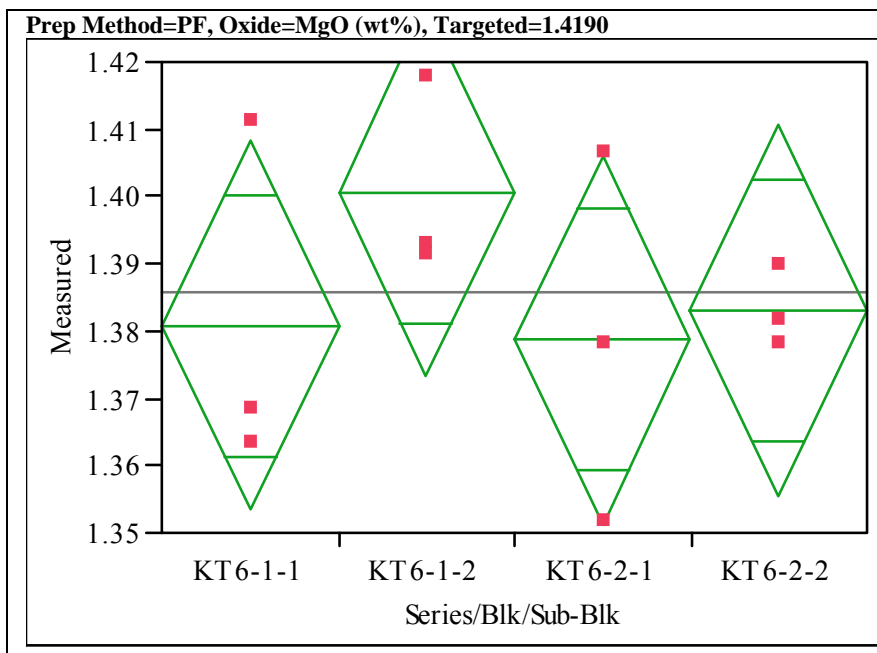

\section{Oneway Anova}

Summary of Fit

Rsquare $\quad 0.212532$

-0.08277
Root Rsquare
Mean Square Error $\quad 0.020646$

Root Mean Square Error $\quad 0.020646$

$\begin{array}{lr}\text { Observations (or Sum Wgts) } & 12\end{array}$

Analysis of Variance

Source DF Sum of Squares Mean Square F Ratio Prob $>$ F

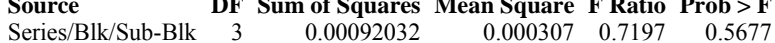

$\begin{array}{llll}\text { Series/Blk/Sub-Blk } & 3 & 0.00092032 & 0.000307 \\ \text { Error } & 8 & 0.00340995 & 0.000426\end{array}$

C. Total

$11 \quad 0.00433027$

Means for Oneway Anova

Level Number Mean Std Error Lower 95\% Upper 95\%

$\begin{array}{lrrrrr}\text { LT6-1-1 } & 3 & 1.38081 & 0.01192 & 1.3533 & 1.4083 \\ \text { KT } & 3 & 1.40071 & 0.01192 & 1.3732 & 1.4282\end{array}$

$\begin{array}{llllll}\text { KT6-1-1 } & 3 & 1.38081 & 0.01192 & 1.3533 & 1.4083 \\ \text { KT6-1-2 } & 3 & 1.40071 & 0.01192 & 1.3732 & 1.4282\end{array}$

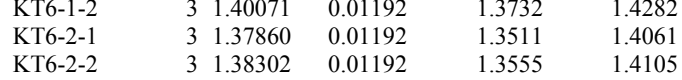

Std Error uses a pooled estimate of error variance

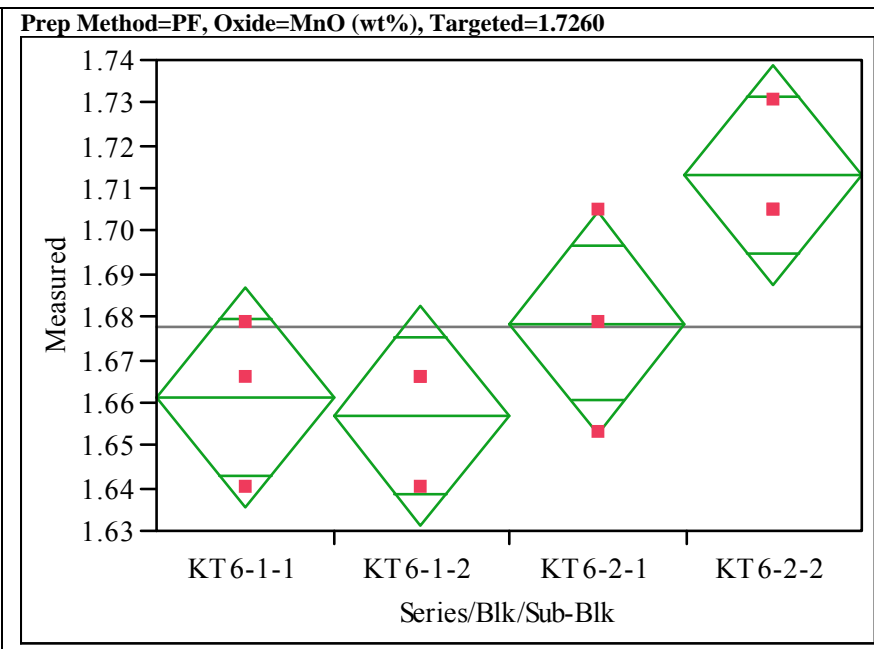

\section{Oneway Anova}

Summary of Fit

Rsquare $\quad 0.659843$

$\begin{array}{ll} & 0.532283 \\ \text { Root Mean Square Error } & 0.019368\end{array}$

Root Mean Square Error $\quad 0.019368$

Observations (or Sum Wgts) 1.677484

Analysis of Variance

Source DF Sum of Squares Mean Square F Ratio Prob $>$ F

$\begin{array}{lrrrrr}\text { Source } & \text { DF } & \text { Sum of Squares } & \text { Mean Square } & & \\ \text { Series/Blk/Sub-Blk Ratio } & 3 & 0.00582130 & 0.001940 & 5.1728 & 0.0281\end{array}$

$\begin{array}{llll}\text { Error } & 8 & 0.00300096 & 0.000375\end{array}$

$\begin{array}{lrr}\text { C. Total } & 11 & 0.00882225\end{array}$

Means for Oneway Anova

Level Number Mean Std Error Lower 95\% Upper 95\%

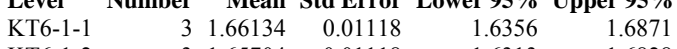

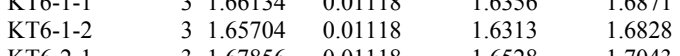

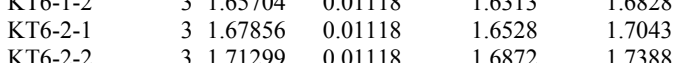

Std Error uses a pooled estimate of error variance 
Exhibit A-3. Statistical Evaluation of the ICP-AES Calibration Effects from the KT06 Batch 1 Results by Oxide. (continued)

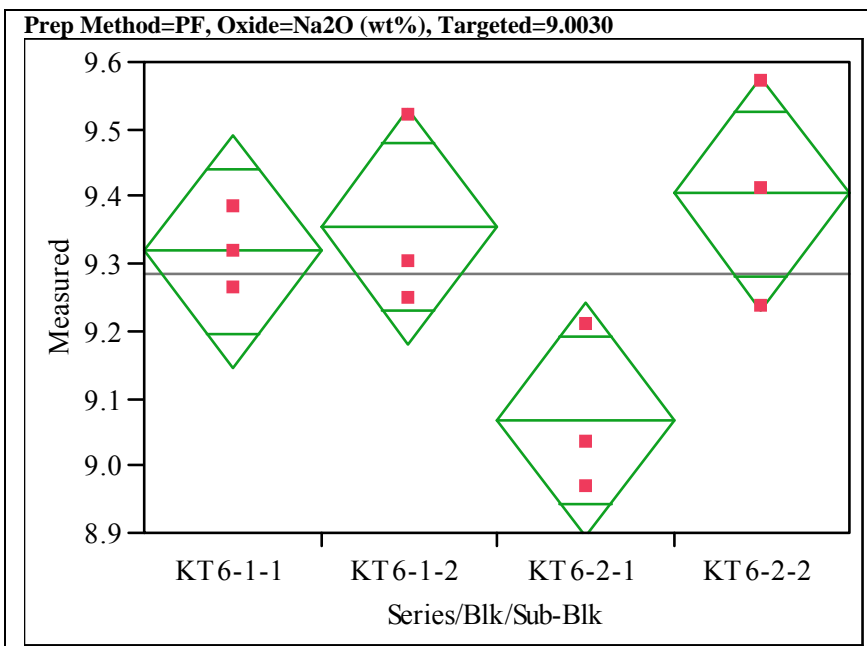

\section{Oneway Anova}

Summary of Fit

$\begin{array}{ll}\text { Rsquare } & 0.598268 \\ \text { Adj } & 0.447619\end{array}$

0.447619
Adj Rsquare

Root Mean Square Error $\quad 0.13052$
Mean of Response

\begin{tabular}{lr} 
Mbservations (or Sum Wgts) & 9.286597 \\
\hline
\end{tabular}

Analysis of Variance

Source DF Sum of Squares Mean Square F Ratio Prob > F

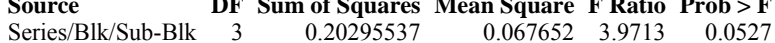

$\begin{array}{lrrr}\text { Series/Blk/Sub-Blk } & 3 & 0.20295537 & 0.067652 \\ \text { Error } & 8 & 0.13628280 & 0.017035\end{array}$

$11 \quad 0.33923817$

Means for Oneway Anova

Level Number Mean Std Error Lower 95\% Upper 95\%

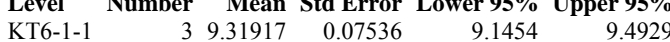

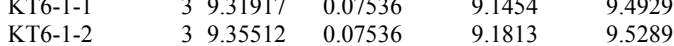

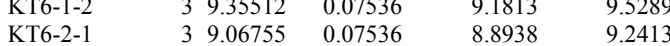

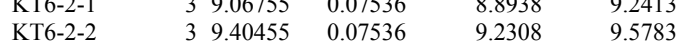

Std Error uses a pooled estimate of error variance

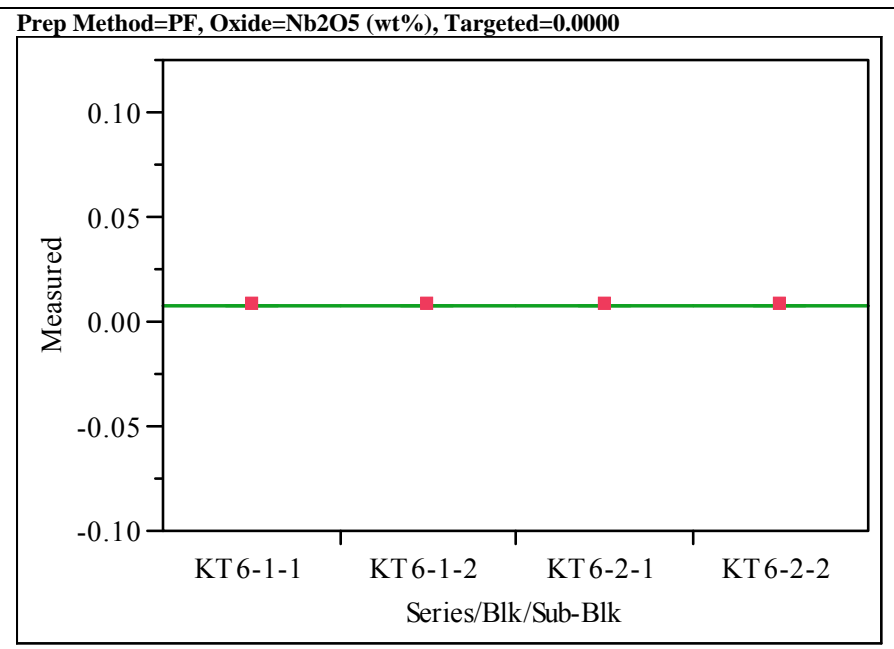

\section{Oneway Anova}

Summary of Fit

Rsquare

Adj Rsquare

-0.375
Adj Rsquare

Root Mean Square Error $\quad 1.06 \mathrm{e}-18$

Observations (or Sum Wgts) 0.007153

Analysis of Variance

Source DF Sum of Squares Mean Square F Ratio Prob $>$ F

$\begin{array}{lrrrrr}\text { Sources/Blk/Sub-Blk } & 3 & 0 & 0 & 0.0000 & 1.0000\end{array}$

$\begin{array}{lrrr}\text { Series/Blk/Sub-Blk } & 3 & 9.0278 \mathrm{e}-36 & 1.128 \mathrm{e}-36 \\ \text { Error } & 8 & 0 & \end{array}$

$11 \quad 9.0278 \mathrm{e}-36$

Means for Oneway Anova

Level Number Mean Std Error Lower 95\% Upper 95\%

$\begin{array}{lrrrrr}\text { Level } & \text { Number } & \text { Mean } & \text { Std Error } & \text { Lower } 95 \% & \text { Upper 95\% } \\ \text { KT6-1-1 } & 3 & 0.007153 & 6.133 \mathrm{e}-19 & 0.00715 & 0.00715 \\ \text { KT6-1-2 } & 3 & 0.007153 & 6.133-19 & 0.00715 & 0.00715\end{array}$

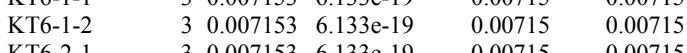

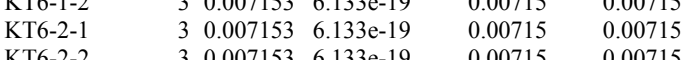

Std Error uses a pooled estimate of error variance 
Exhibit A-3. Statistical Evaluation of the ICP-AES Calibration Effects from the KT06 Batch 1 Results by Oxide. (continued)

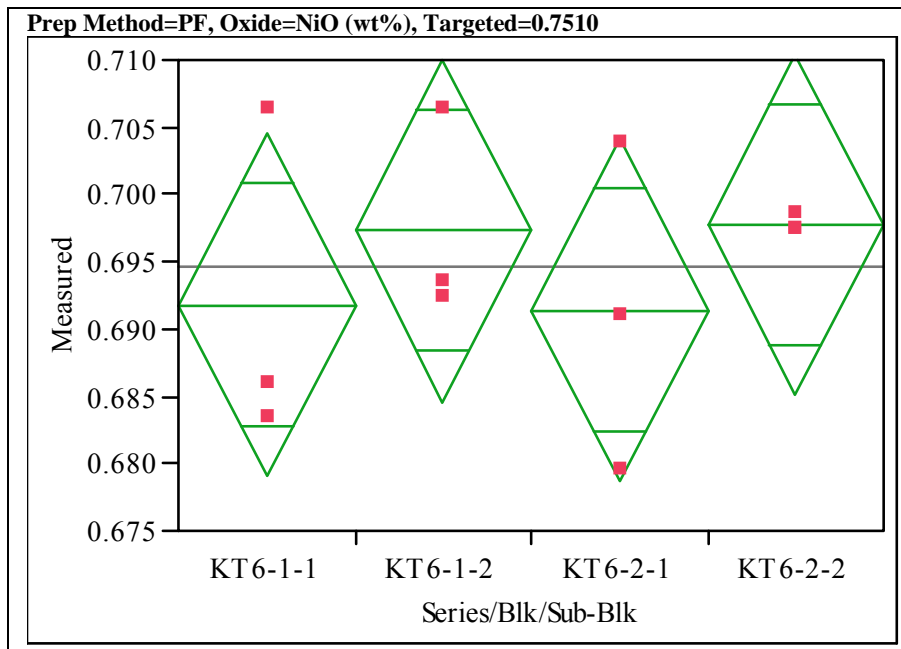

Oneway Anova
Summary of Fit

Rsquare $\quad 0.127343$

-0.1999
Adj Rsquare

$\begin{array}{ll}\text { Root Mean Square Error } & 0.009544 \\ \text { Mean of Response } & 0.694573\end{array}$

$\begin{array}{lr}\text { Mbservations (or Sum Wgts) } & 12\end{array}$

Analysis of Variance

$\begin{array}{lrrrrr}\text { Source } & \text { DF } & \text { Sum of Squares } & \text { Mean Square } & \text { F Ratio } & \text { Prob }>\text { F } \\ \text { Series/Blk/Sub-Blk } & 3 & 0.00010633 & 0.000035 & 0.3891 & 0.7641\end{array}$

$\begin{array}{llll}\text { Series/Blk/Sub-Blk } & 3 & 0.00010633 & 0.000035 \\ \text { Error } & 8 & 0.00072867 & 0.000091 \\ \text { C } & 11 & 0.00083500 & \end{array}$

C. Total

$11 \quad 0.00083500$

0.000091

Means for Oneway Anova

Level Number Mean Std Error Lower 95\% Upper 95\%

$\begin{array}{lrrrrr}\text { KT6-1-1 } & 3 & 0.691816 & 0.00551 & 0.67911 & 0.70452\end{array}$

$\begin{array}{llllll}\text { KT6-1-1 } & 3 & 0.691816 & 0.00551 & 0.67911 & 0.70452 \\ \text { KT6-1-2 } & 3 & 0.697330 & 0.00551 & 0.68462 & 0.71004 \\ \text { KT6-2-1 } & 3 & 0.691392 & 0.00551 & 0.67869 & 0.70410\end{array}$

$\begin{array}{llllll}\text { KT6-1-2 } & 3 & 0.697330 & 0.00551 & 0.68462 & 0.71004 \\ \text { KT6-2-1 } & 3 & 0.691392 & 0.00551 & 0.67869 & 0.70410\end{array}$

KT6-2-2 $10.697754-0.00551-0.68$

Prep Method $=$ PF, Oxide $=\mathbf{P b O}(\mathrm{wt} \%)$, Targeted $=\mathbf{0 . 0 0 0 0}$

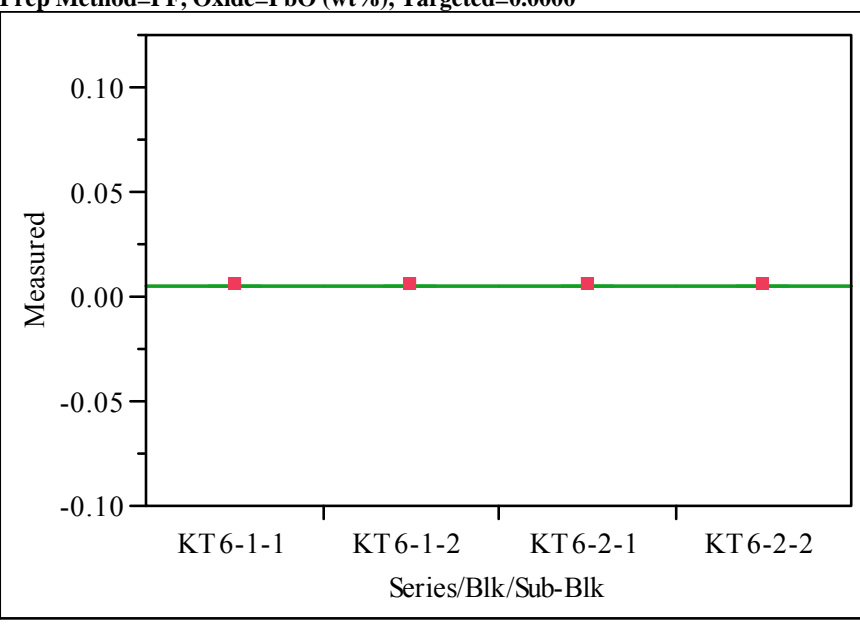

\section{Oneway Anova}

Summary of Fit

Rsquare

Adj Rsquare

-0.375
Adj Rsquare

Root Mean Square Error $\quad 1.06 \mathrm{e}-18$

Observations (or Sum Wgts) 0.005386

Analysis of Variance

Source DF Sum of Squares Mean Square F Ratio Prob $>$ F

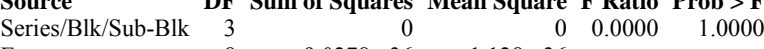

$\begin{array}{lrrr}\text { Error } & 8 & 9.0278 \mathrm{e}-36 & 1.128 \mathrm{e}-36 \\ \text { C. Total } & 11 & 9.0278 \mathrm{e}-36 & \end{array}$

Means for Oneway Anova

Level Number Mean Std Error Lower 95\% Upper 95\%

$\begin{array}{lrrrrr}\text { Level } & \text { Number } & \text { Mean } & \text { Std Error } & \text { Lower } 95 \% & \text { Upper 95\% } \\ \text { KT6-1-1 } & 3 & 0.005386 & 6.133 \mathrm{e}-19 & 0.00539 & 0.00539\end{array}$

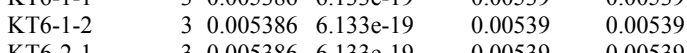

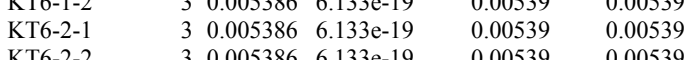

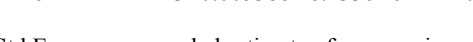

Std Error uses a pooled estimate of error variance 
Exhibit A-3. Statistical Evaluation of the ICP-AES Calibration Effects from the KT06 Batch 1 Results by Oxide. (continued)

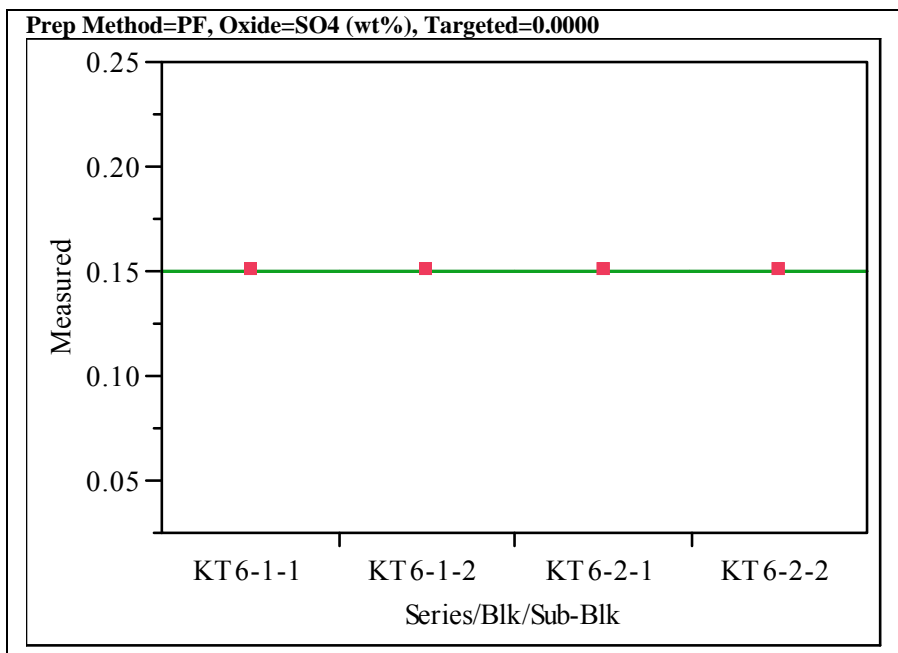

\section{Oneway Anova}

Summary of Fit

Rsquare

Adj Rsquare

$\begin{array}{lr}\text { Root Mean Square Error } & 0 \\ \text { Mean of Response } & 0.149795\end{array}$

Analysis of Variance

Source DF Sum of Squares Mean Square F Ratio Prob $>$ F

$\begin{array}{lrrr}\text { Source } & \text { DF } & \text { Sum of Squares } & \text { Mean Square } \\ \text { Series/Blk/Sub-Blk } & 3 & 0 & 0 \\ \text { Error } & 8 & 0 & 0 \\ \text { C. } & 1 & 0 & \end{array}$

Error

C. Total

Means for Oneway Anova

Level Number Mean Std Error Lower 95\% Upper 95\%

$\begin{array}{llllll}\text { KT6-1-1 } & 3 & 0.149795 & 0 & 0.14980 & 0.14980 \\ \text { KT6-1-2 } & & 3 & 0.149795 & & 0.14980\end{array}$

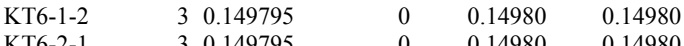

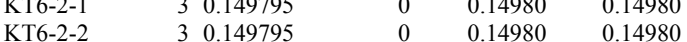

Std Error uses a pooled estimate of error variance

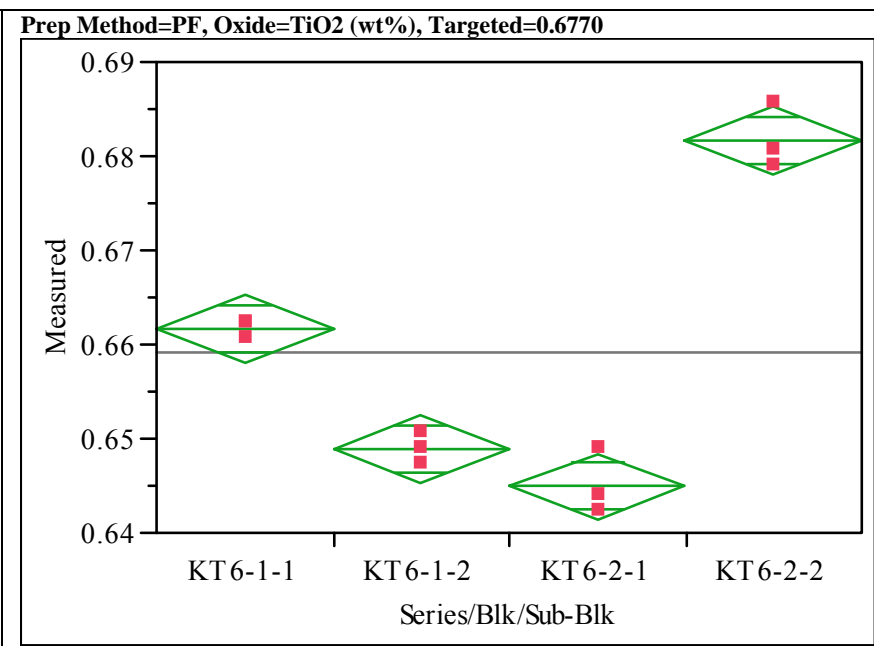

\section{Oneway Anova}

Summary of Fit

$\begin{array}{ll}\text { Rsquare } & 0.977882 \\ \text { Adj Rsquare } & 0.969588\end{array}$

0.969588
Root Mean Square Error $\quad 0.002637$

Root Mean Square Error $\quad 0.002637$

Observations (or Sum Wots)

Analysis of Variance

Source DF Sum of Squares Mean Square F Ratio Prob $>$ F

$\begin{array}{lrrrrr}\text { Source } & \text { DF } & \text { Sum of Squares } & \text { Mean Square } & \text { F Ratio } \\ \text { Series/Blk/Sub-Blk } & 3 & 0.00246018 & 0.000820 & 117.9000 & <.0001\end{array}$

$\begin{array}{lrrr}\text { Error } & 8 & 0.00005564 & 6.956 \mathrm{e}-6\end{array}$

$\begin{array}{lrr}\text { C. Total } & 11 & 0.00251583\end{array}$

Means for Oneway Anova

Level Number Mean Std Error Lower 95\% Upper 95\%

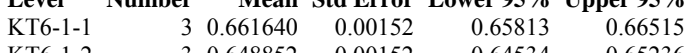

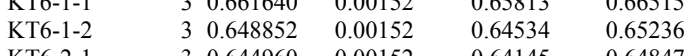

$\begin{array}{llllll}\text { KT6-1-2 } & 3 & 0.648852 & 0.00152 & 0.64534 & 0.65236 \\ \text { KT6-2-1 } & 3 & 0.644960 & 0.00152 & 0.64145 & 0.64847 \\ \text { KT6-2-2 } & 3 & 0.681656 & 0.00152 & 0.67814 & 0.68517\end{array}$

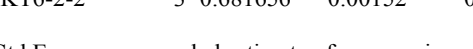

Std Error uses a pooled estimate of error variance 
Exhibit A-3. Statistical Evaluation of the ICP-AES Calibration Effects from the KT06 Batch 1 Results by Oxide. (continued)

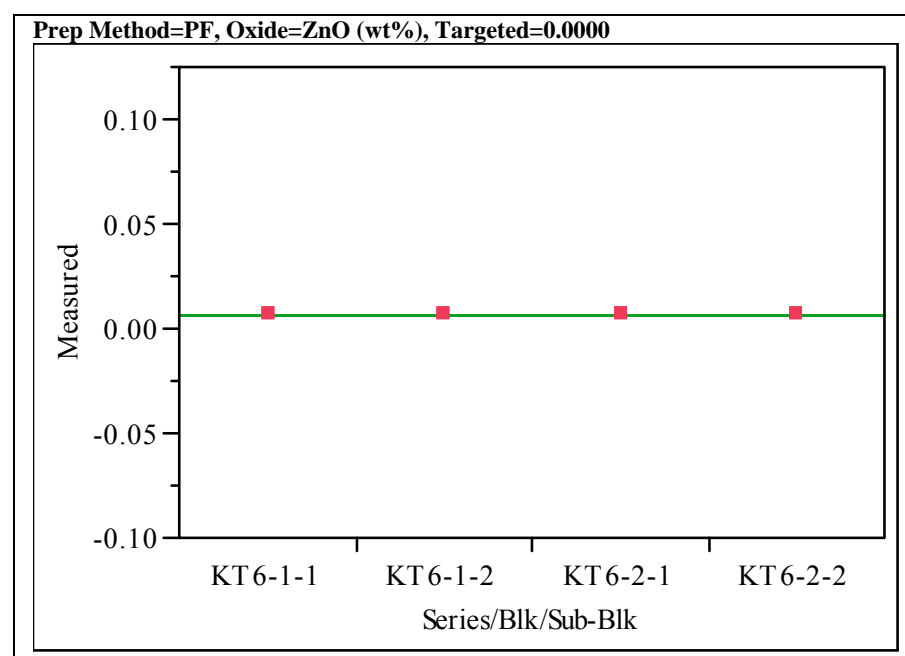

\section{Oneway Anova}

Summary of Fit

Rsquare

Adj Rsquare

Root Mean Square Error $\quad 0$
Mean of Response

Mean of Response $\quad 0.006224$

Analysis of Variance

Source DF Sum of Squares Mean Square F Ratio Prob $>$ F

$\begin{array}{lrrr}\text { Source } & \text { DF } & \text { Sum of Squares } & \text { Mean Square } \\ \text { Series/Blk/Sub-Blk } & 3 & 0 & 0 \\ \text { Error } & 8 & 0 & 0 \\ \text { C. } & 1 & 0 & \end{array}$

Error

0

C. Total

11

Means for Oneway Anova

Level Number Mean Std Error Lower 95\% Upper 95\%

$\begin{array}{lrrrrr}\text { KT6-1-1 } & 3 & 0.006224 & 0 & 0.00622 & 0.00622\end{array}$

$\begin{array}{llllll}\text { KT6-1-1 } & 3 & 0.006224 & 0 & 0.00622 & 0.00622 \\ \text { KT6-1-2 } & 3 & 0.006224 & 0 & 0.00622 & 0.00622\end{array}$

$\begin{array}{llllll}\text { KT6-1-1 } & 3 & 0.006224 & 0 & 0.00622 & 0.00622 \\ \text { KT6-1-2 } & 3 & 0.006224 & 0 & 0.00622 & 0.00622 \\ \text { KT6-2-2 } & 3 & 0.006224 & 0 & 0.00622 & 0.00622\end{array}$

Std Error uses a pooled estimate of error variance

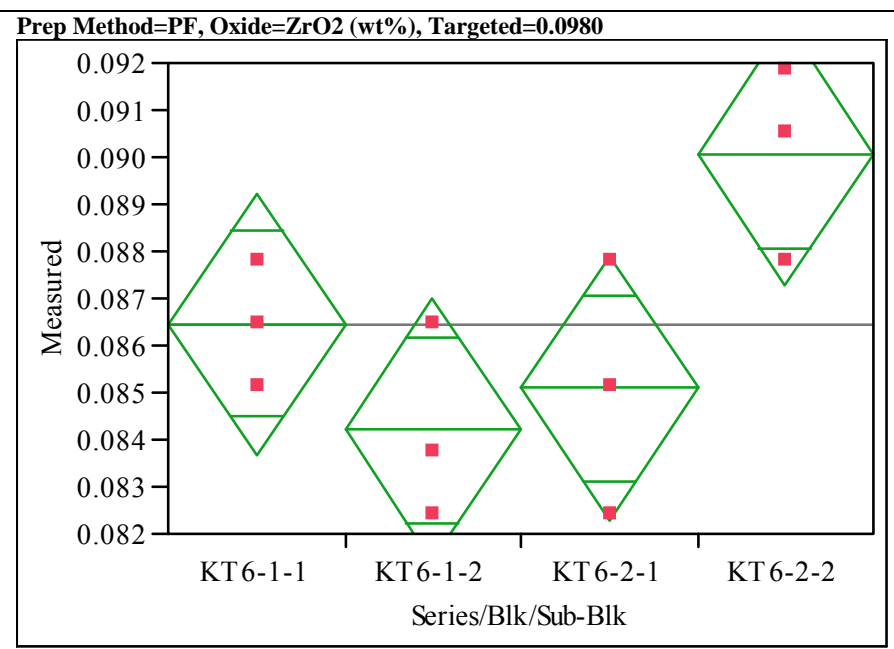

\section{Oneway Anova}

Summary of Fit

$\begin{array}{ll}\text { Rsquare } & 0.628205 \\ \text { Adj Rsquare } & 0.488782\end{array}$

$\begin{array}{lr}\text { Adj Rsquare } & 0.488782 \\ \text { Root Mean Square Error } \quad 0.0021\end{array}$

$\begin{array}{lr}\text { Root Mean Square Error } & 0.0021 \\ \text { Mean of Response } & 0.086451\end{array}$

Observations (or Sum Wgts) 0.086451

Analysis of Variance

Source DF Sum of Squares Mean Square F Ratio Prob $>$ F

$\begin{array}{lrrrrr}\text { Source } & \text { DF } & \text { Sum of Squares } & \text { Mean Square } & & \\ \text { Series/Blk/Sub-Blk } & 3 & 0.00005961 & 0.000020 & 4.5057 & 0.0394\end{array}$

$\begin{array}{lrrr}\text { Error } & 8 & 0.00003528 & 4.41 \mathrm{e}-6\end{array}$

$\begin{array}{lrr}\text { C. Total } & 11 & 0.00009488\end{array}$

Means for Oneway Anova

Level Number Mean Std Error Lower 95\% Upper 95\%

$\begin{array}{lrrrrr}\text { Level } & \text { Number } & \text { Mean } & \text { Std Error } & \text { Lower 95\% } & \text { Opper 95\% } \\ \text { KT6-1-1 } & 3 & 0.086451 & 0.00121 & 0.08366 & 0.08925\end{array}$

$\begin{array}{llllll}\text { KT6-1-1 } & 3 & 0.086451 & 0.00121 & 0.08366 & 0.08925 \\ \text { KT6-1-2 } & 3 & 0.084200 & 0.00121 & 0.08140 & 0.08700 \\ \text { KT6-2-1 } & 3 & 0.085100 & 0.00121 & 0.08230 & 0.08790\end{array}$

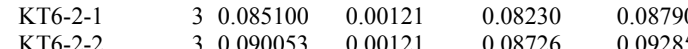

Std Error uses a pooled estimate of error variance 


\section{Exhibit A-4. Plots of Measured versus Targeted Concentrations by} KT06 Glass ID by Oxide.
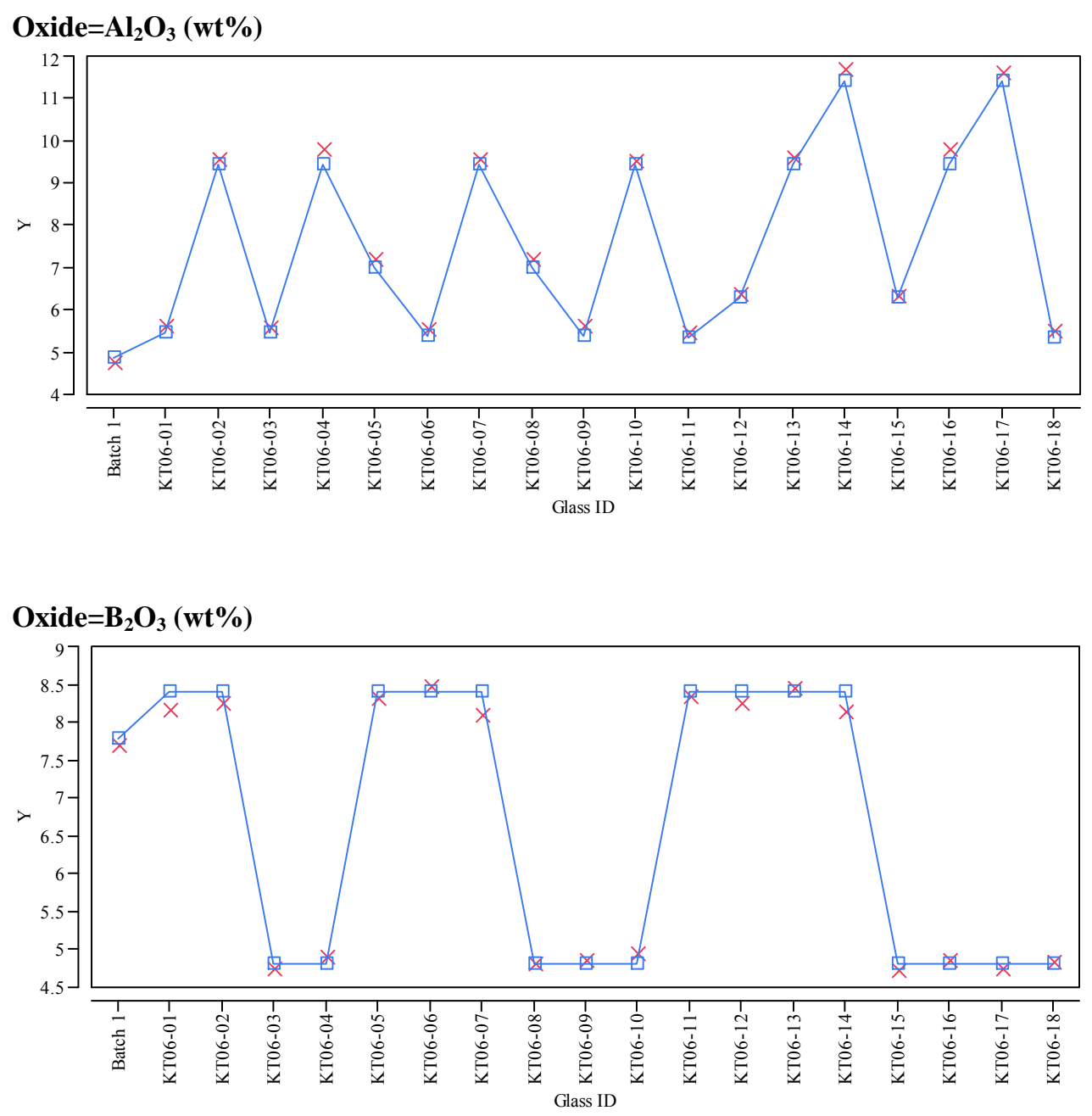

\section{Oxide $=\mathrm{BaO}(\mathrm{wt} \%)$}

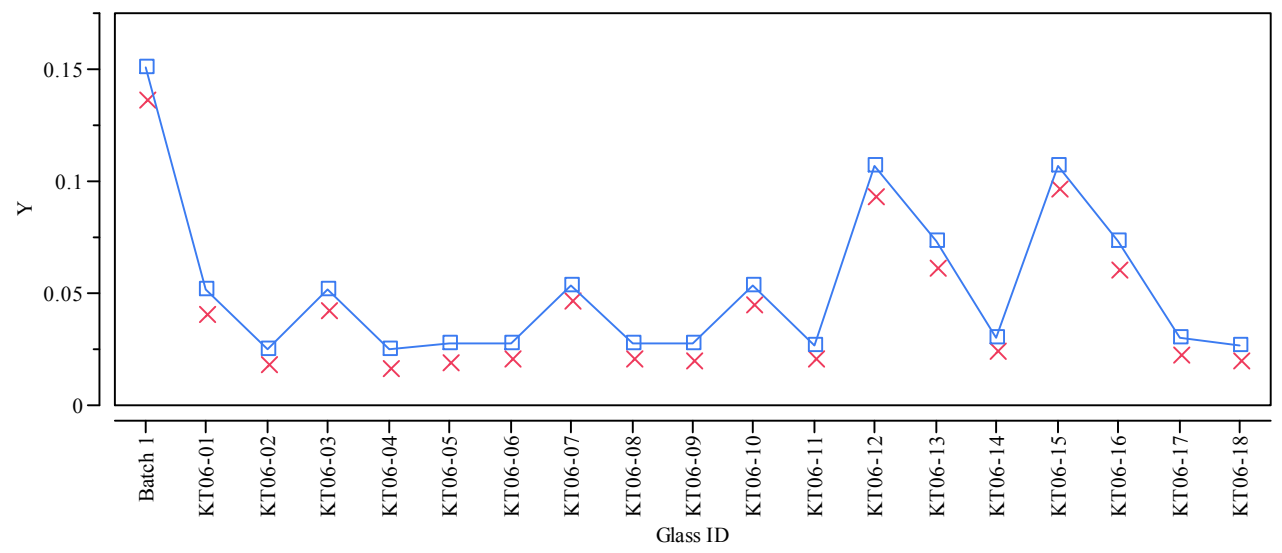

$\mathrm{Y} \times$ Measured $\square$ - Targeted 
Exhibit A-4. Plots of Measured versus Targeted Concentrations by KT06 Glass ID by Oxide. (continued)
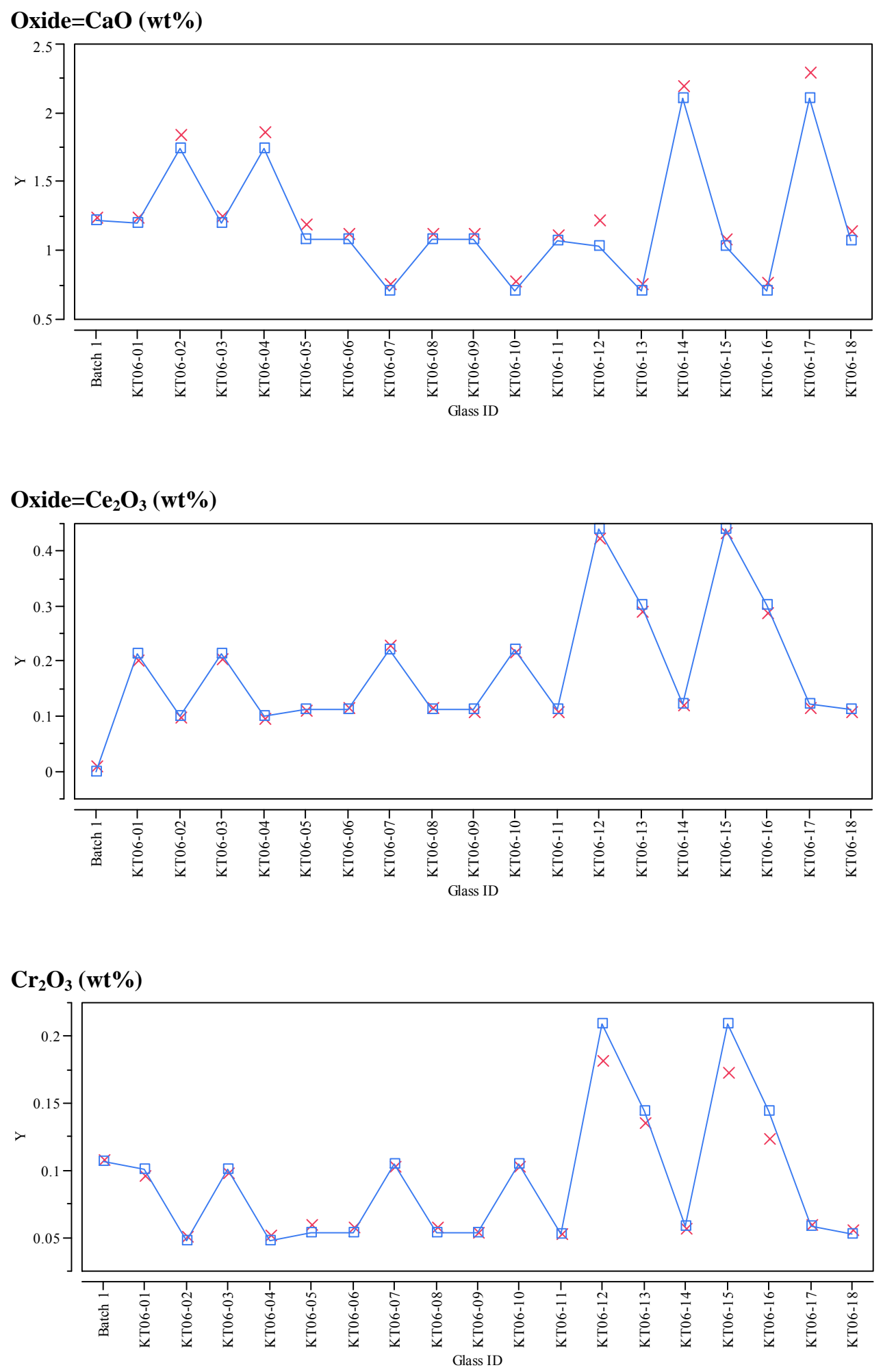

$\mathrm{Y} \times$ Measured $\square-$ Targeted 
Exhibit A-4. Plots of Measured versus Targeted Concentrations by KT06 Glass ID by Oxide. (continued)

\section{Oxide $=\mathrm{CuO}(\mathrm{wt} \%)$}

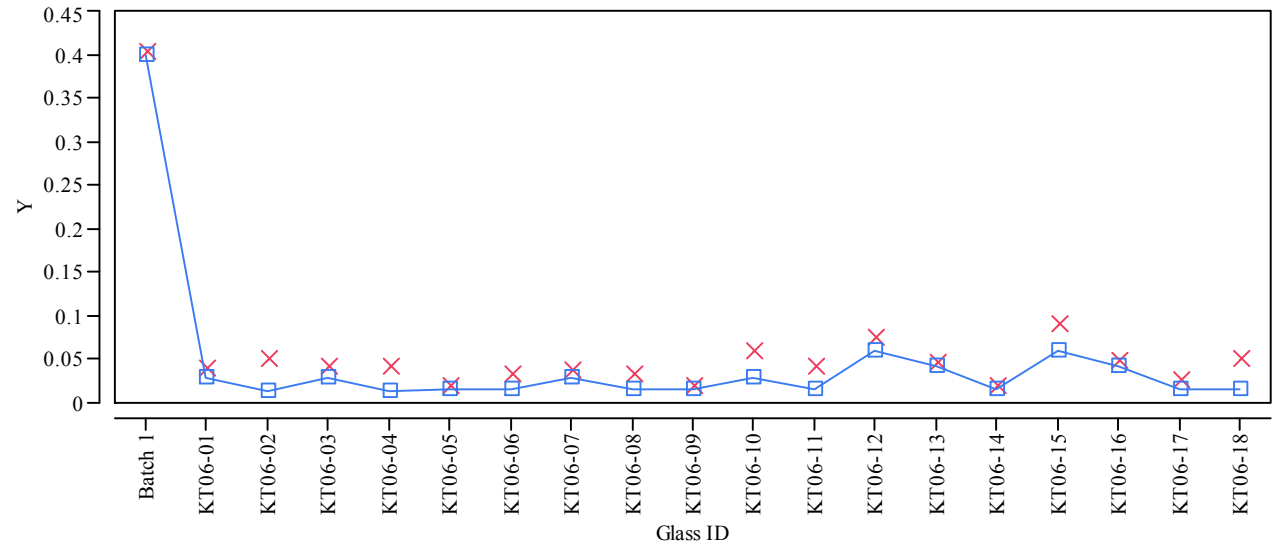

\section{Oxide $=\mathrm{Fe}_{2} \mathrm{O}_{3}(\mathrm{wt} \%)$}

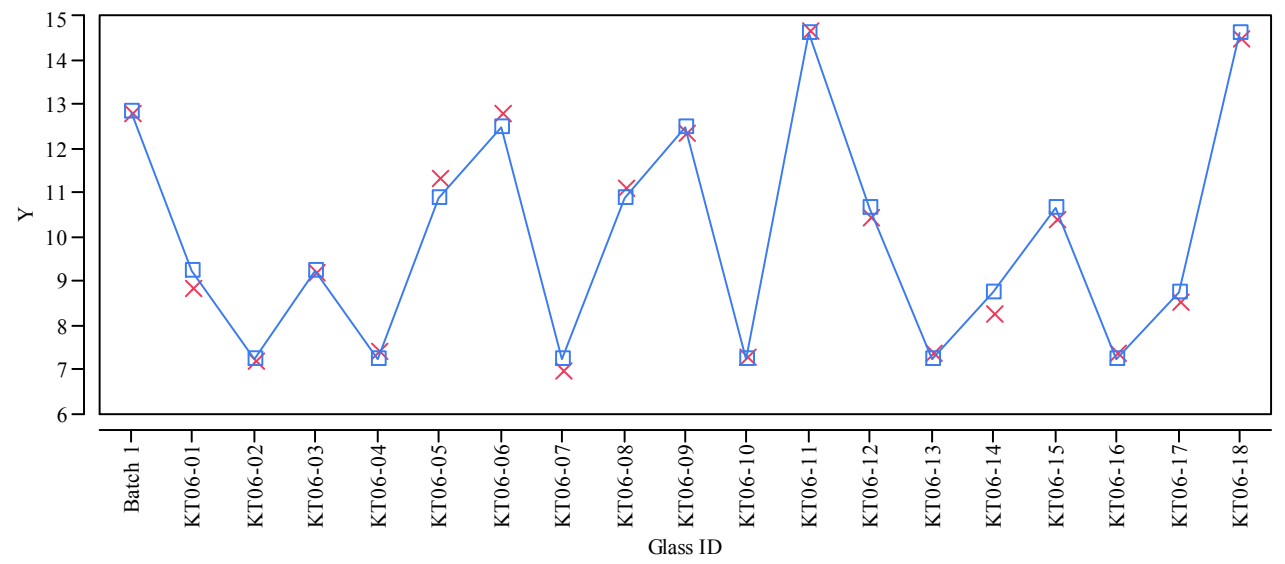

\section{Oxide $=\mathrm{K}_{2} \mathbf{O}(\mathbf{w t} \%)$}

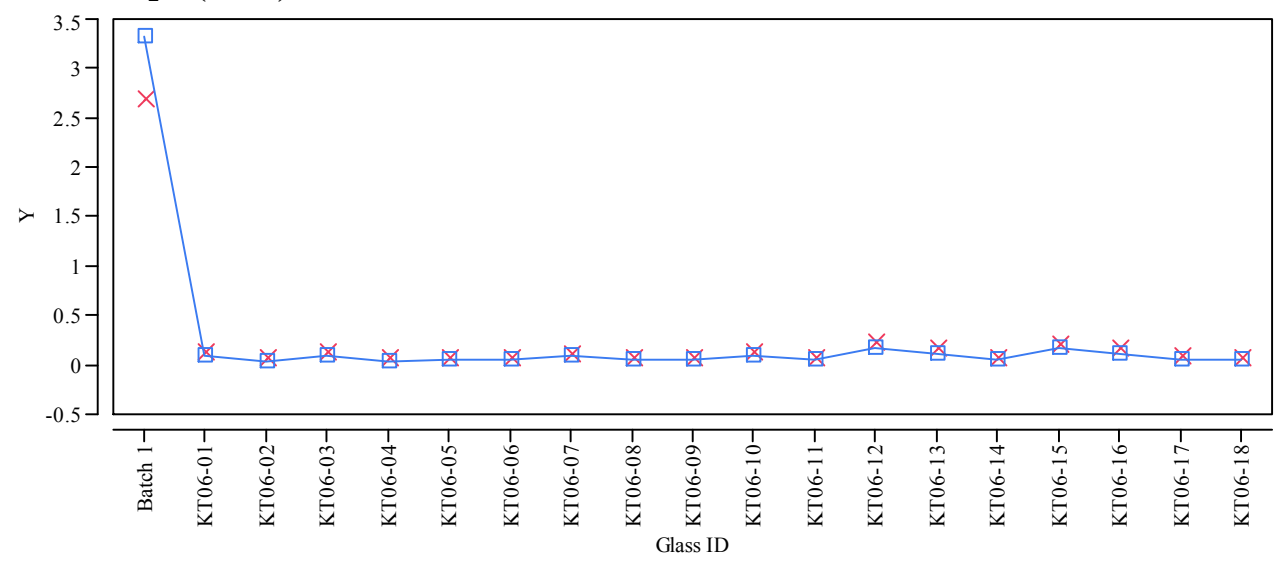

Y $\times$ Measured $\square$ Targeted 


\section{Exhibit A-4. Plots of Measured versus Targeted Concentrations by} KT06 Glass ID by Oxide. (continued)

Oxide $=\mathrm{La}_{2} \mathrm{O}_{3}(\mathrm{wt} \%)$

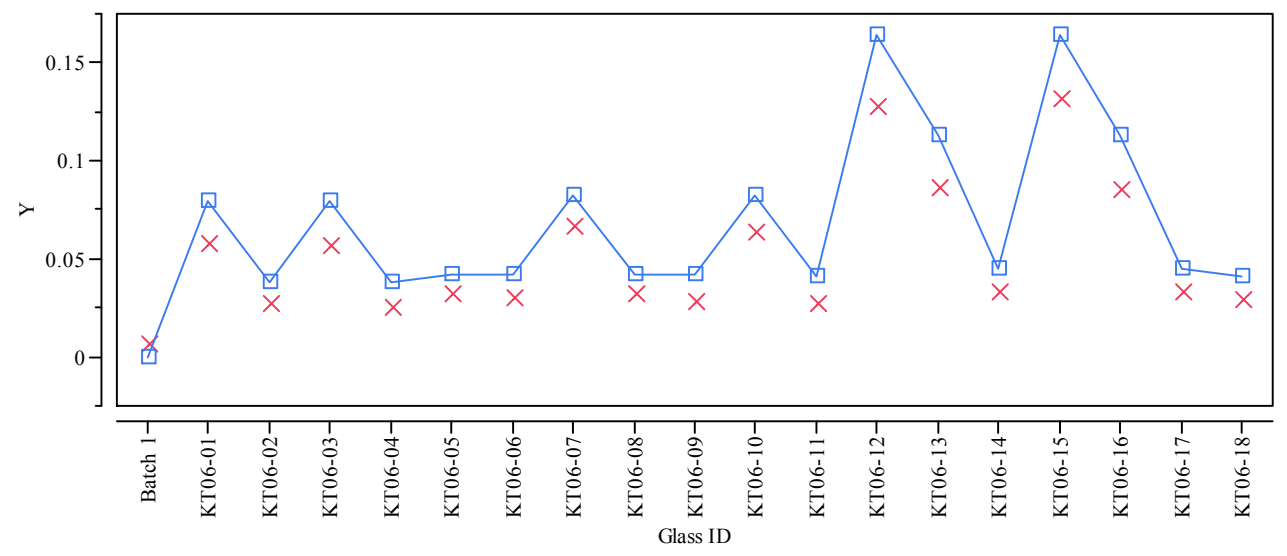

\section{Oxide $=\mathrm{Li}_{2} \mathrm{O}(\mathrm{wt} \%)$}

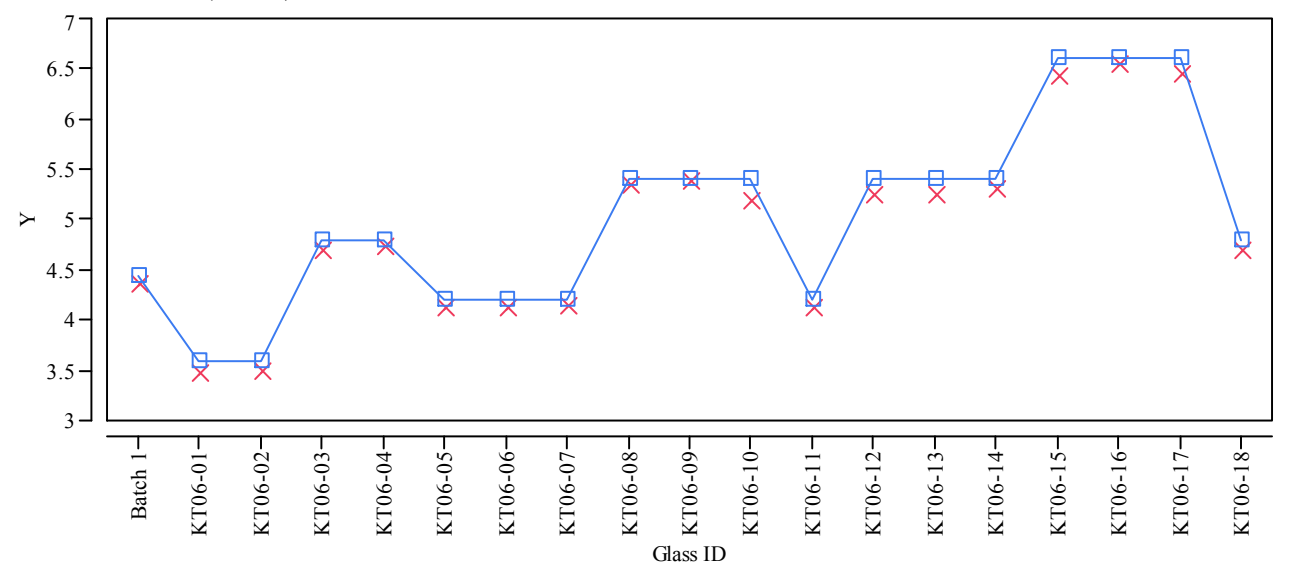

\section{Oxide $=\mathrm{MgO}(\mathrm{wt} \%)$}

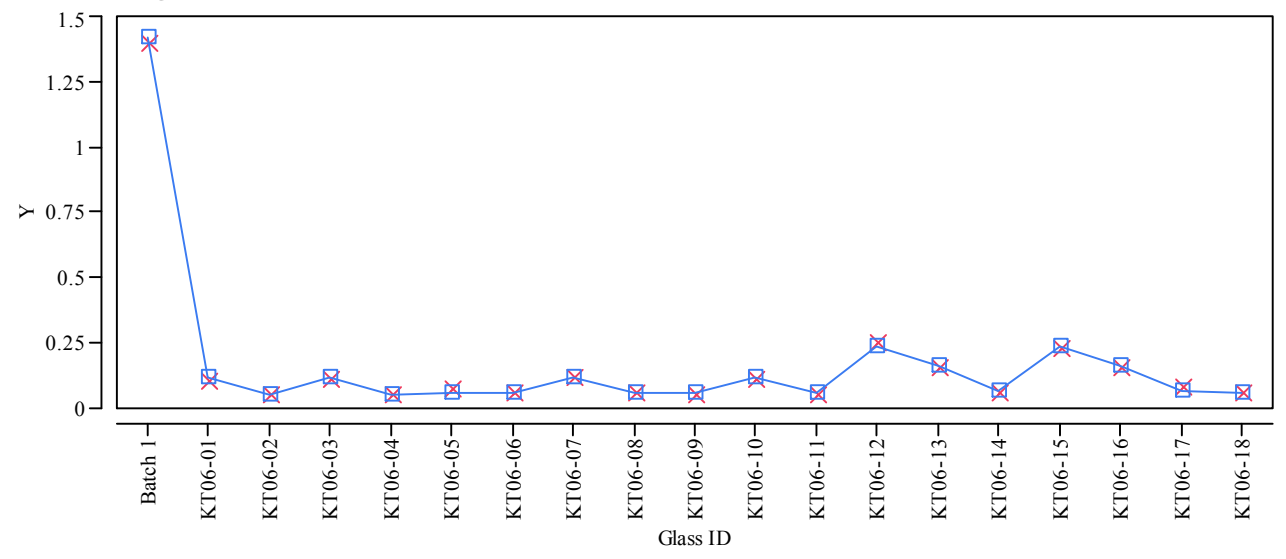

Y $\times$ Measured $\square$ - Targeted 
Exhibit A-4. Plots of Measured versus Targeted Concentrations by KT06 Glass ID by Oxide. (continued)

\section{Oxide $=\mathrm{MnO}(\mathrm{wt} \%)$}

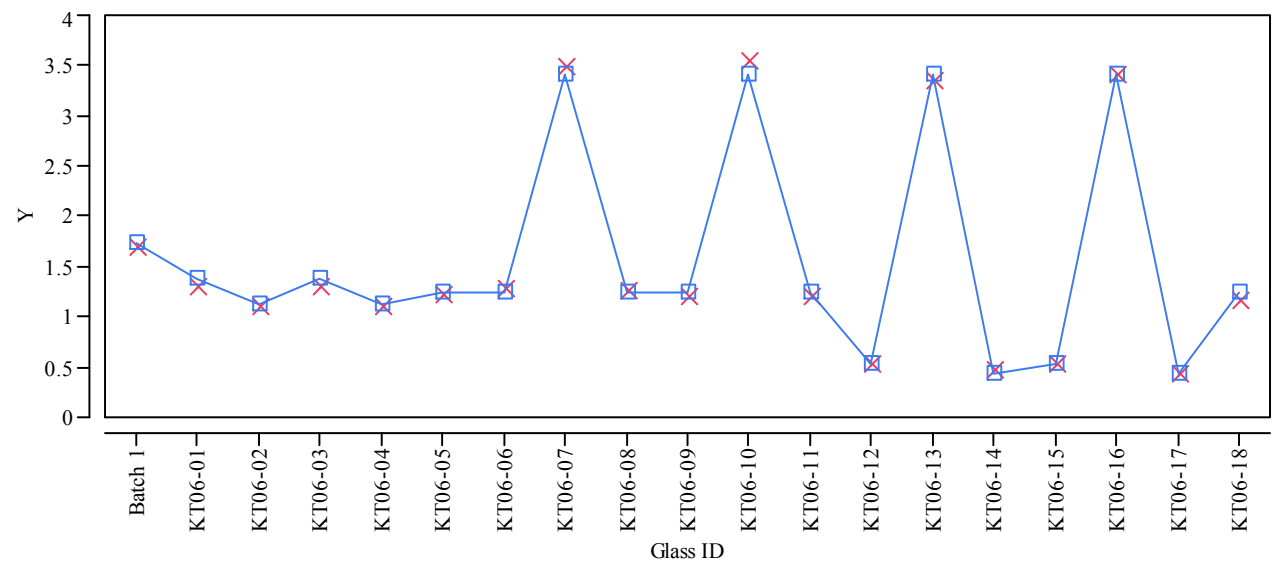

\section{Oxide $=\mathrm{Na}_{2} \mathrm{O}(\mathrm{wt} \%)$}

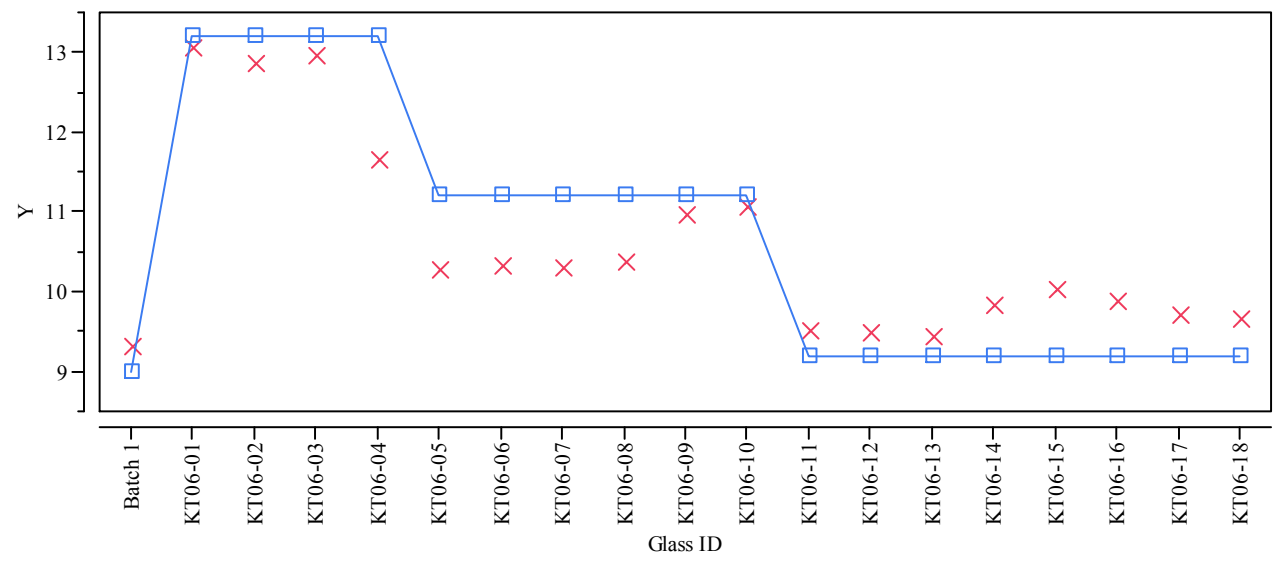

\section{Oxide $=\mathrm{Nb}_{2} \mathrm{O}_{5}(\mathrm{wt} \%)$}

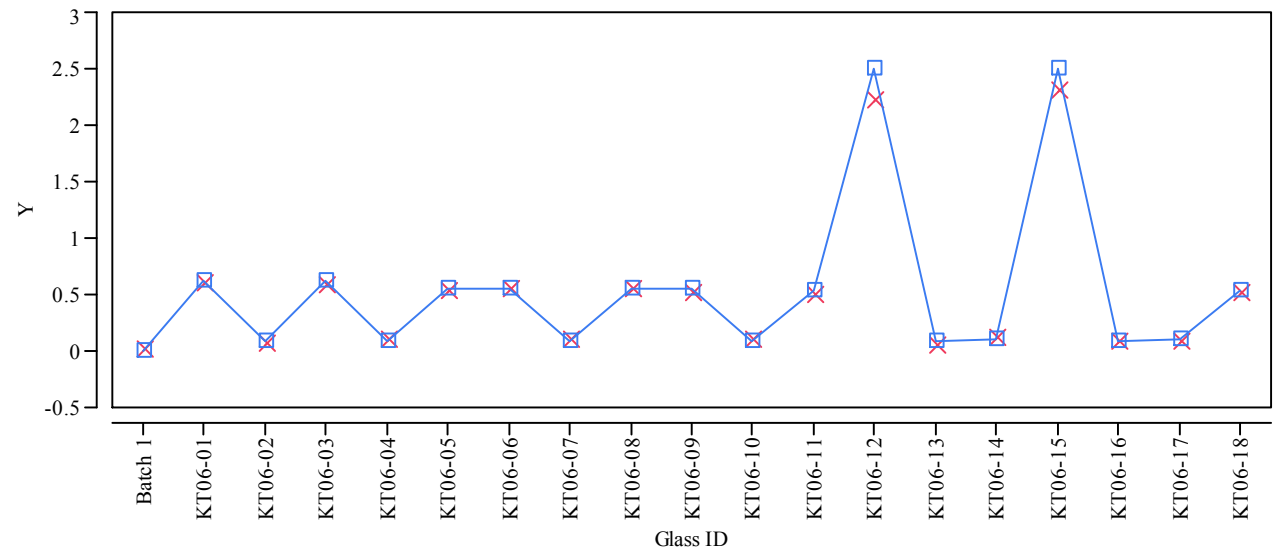

$\mathrm{Y} \times$ Measured $\square$ - Targeted 


\section{Exhibit A-4. Plots of Measured versus Targeted Concentrations by} KT06 Glass ID by Oxide. (continued)

\section{Oxide $=\mathrm{NiO}(\mathrm{wt} \%)$}
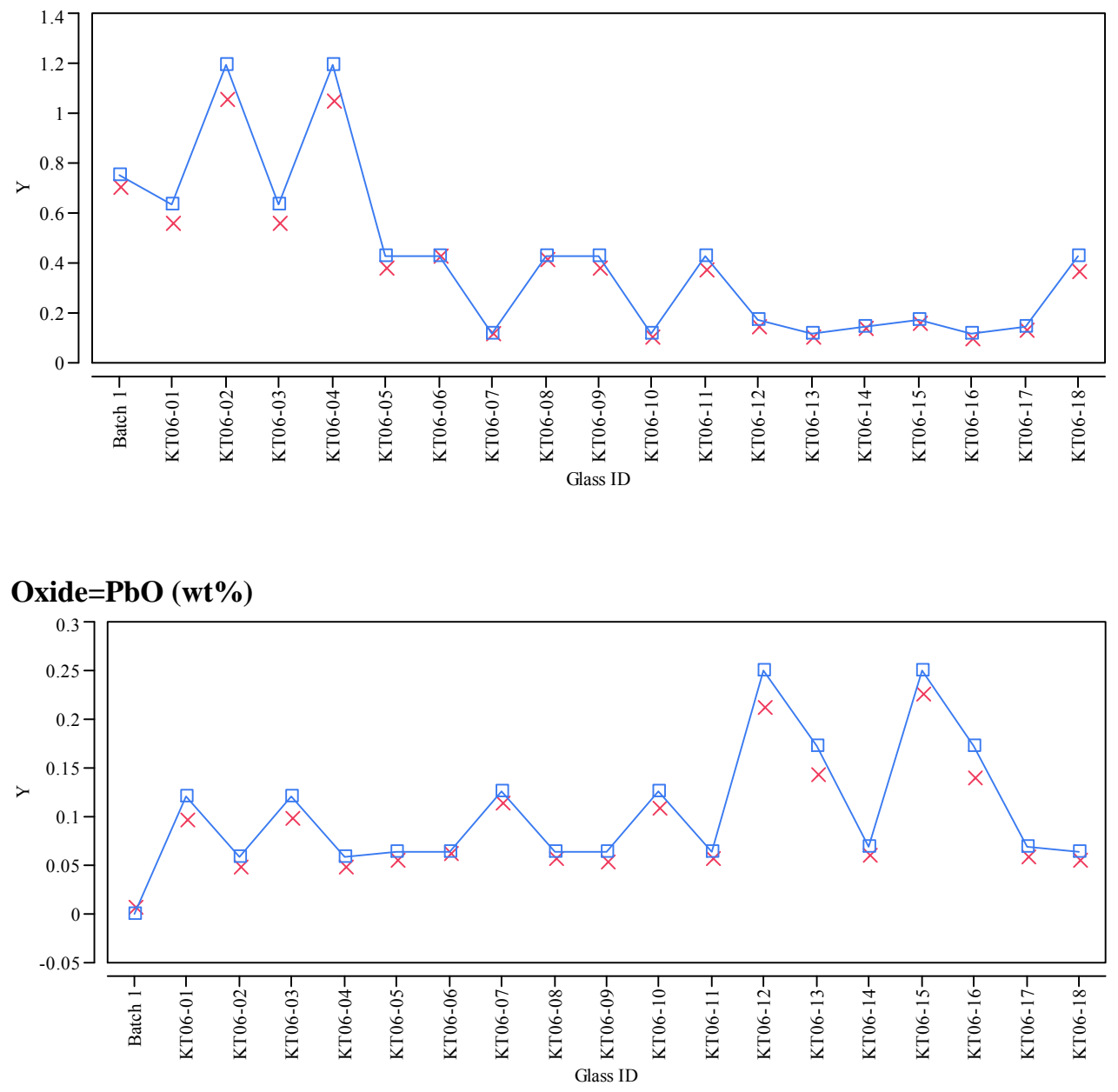

\section{Oxide $=\mathrm{SiO}_{2}(\mathrm{wt} \%)$}

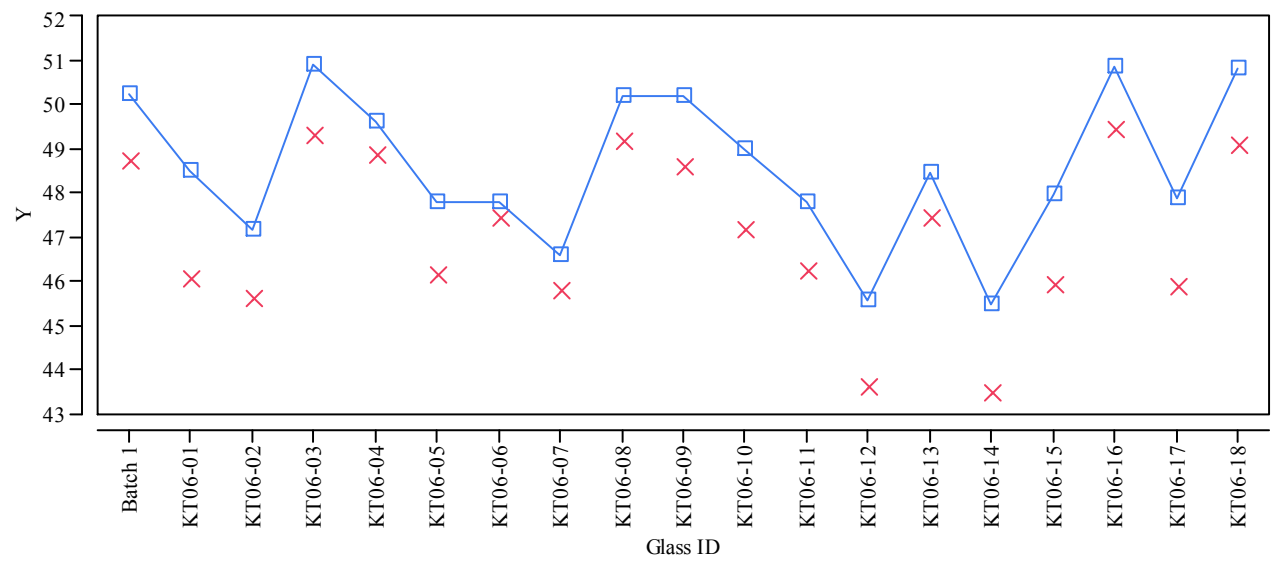

$\mathrm{Y} \times$ Measured $\square$ - Targeted 
Exhibit A-4. Plots of Measured versus Targeted Concentrations by KT06 Glass ID by Oxide. (continued)

Oxide $=\mathrm{SO}_{4}(\mathrm{wt} \%)$

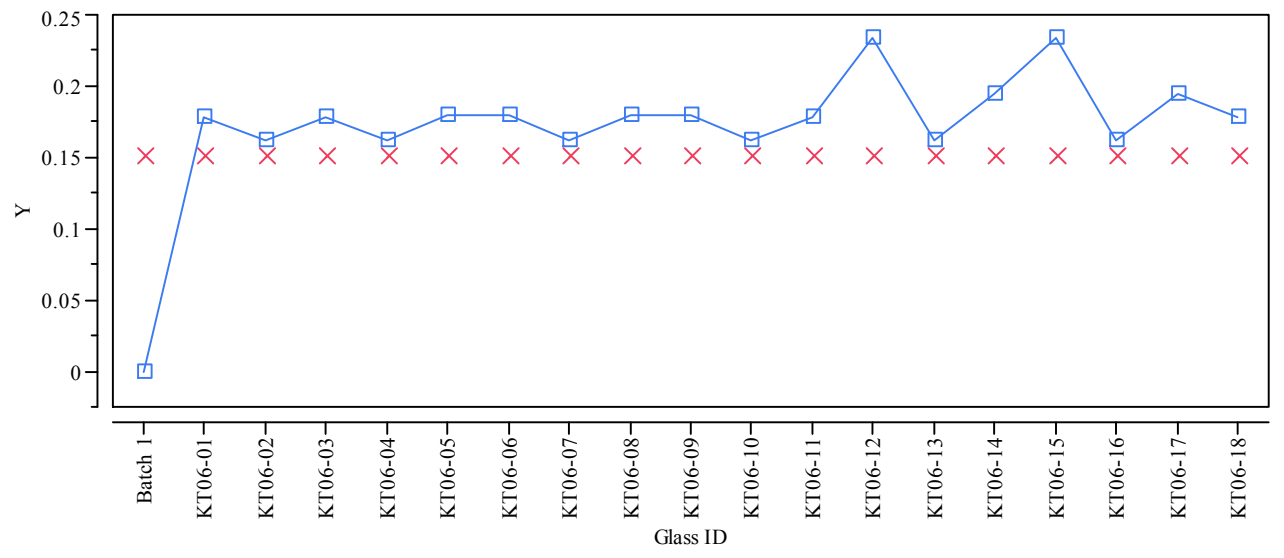

Oxide $=\mathrm{TiO}_{2}(\mathrm{wt} \%)$

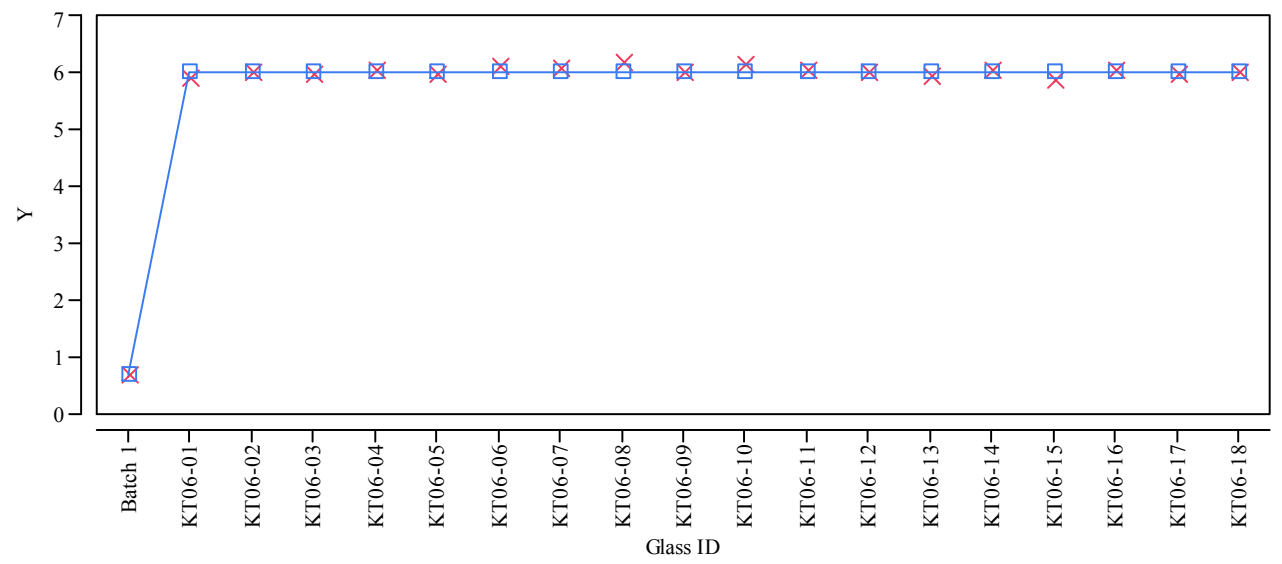

Oxide $=\mathrm{ZnO}(\mathrm{wt} \%)$

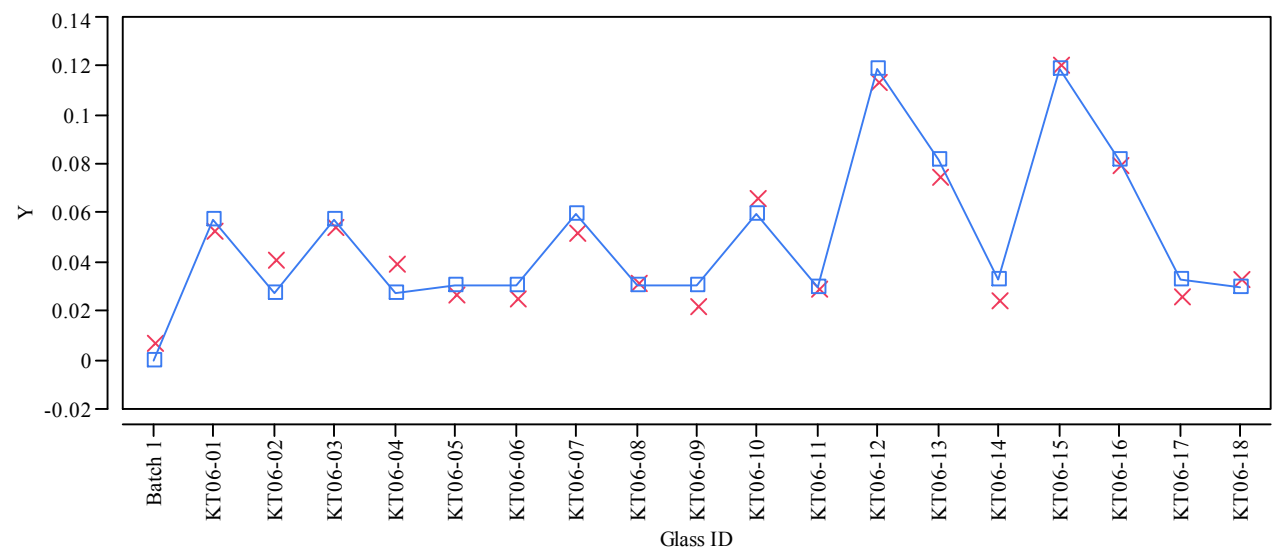

Y $\times$ Measured $\square$ - Targeted 


\section{Exhibit A-4. Plots of Measured versus Targeted Concentrations by} KT06 Glass ID by Oxide. (continued)

Oxide $=\mathrm{ZrO}_{2}(\mathrm{wt} \%)$

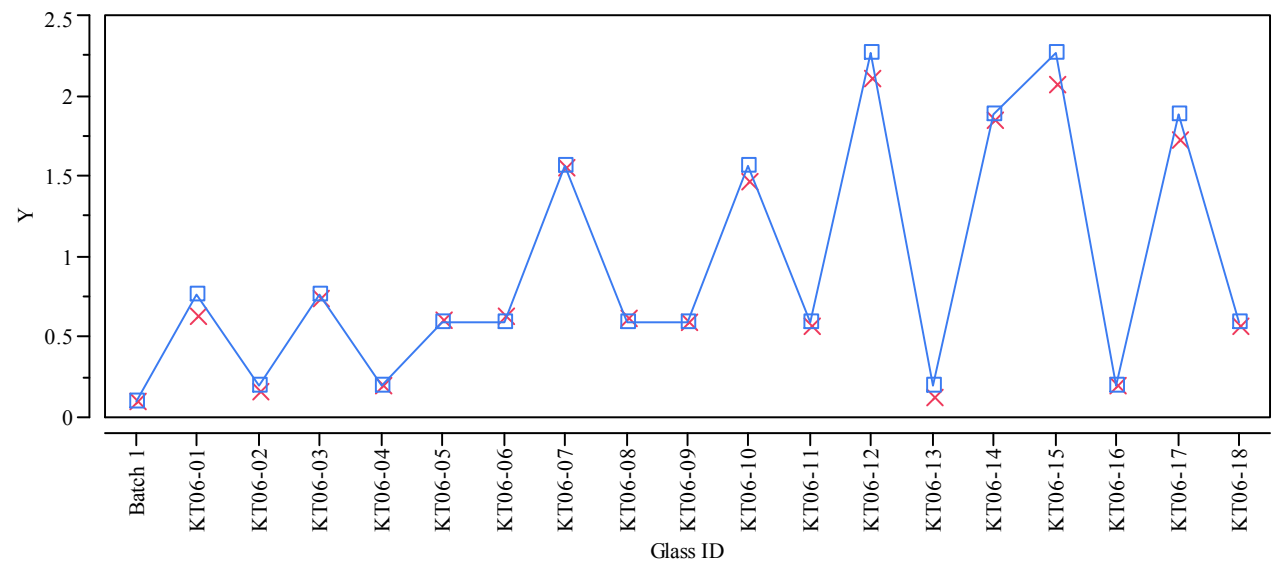

Sum of Oxides

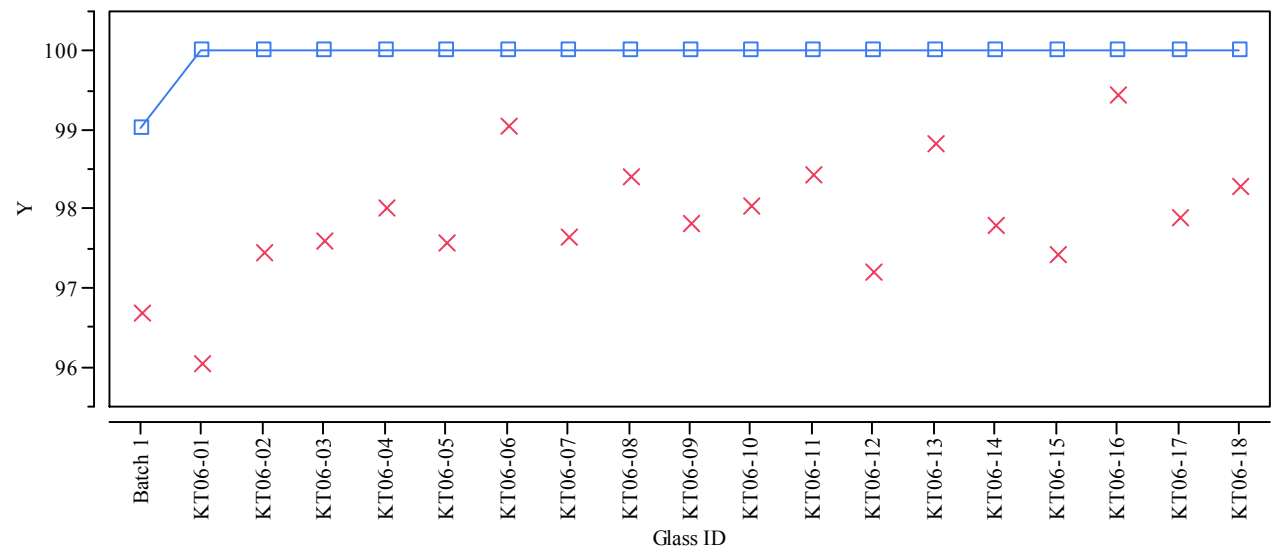

$\mathrm{Y} \times$ Measured $\square-$ Targeted 
SRNL-STI-2010-00687

Revision 0

Appendix B. Data Supporting the PCT Measurements of the KT06-Series Glasses 
Table B-1. Measurements of the PCT Solutions for the KT06-Series Glasses As-Received (ar) and After Appropriate Adjustments (ppm).

\begin{tabular}{|c|c|c|c|c|c|c|c|c|c|c|c|c|}
\hline Glass ID & Heat Treatment & Block & Seq & Lab ID & B (ar) & Li (ar) & Na (ar) & Si (ar) & B (ppm) & Li (ppm) & $\mathrm{Na}(\mathrm{ppm})$ & Si (ppm) \\
\hline Soln Std & ref & 1 & 1 & std-11 & 21.3 & 9.88 & 84.5 & 50.3 & 21.30 & 9.88 & 84.50 & 50.30 \\
\hline KT06-17 & quenched & 1 & 2 & d043 & 4.99 & 12.5 & 17.2 & 50.1 & 8.32 & 20.83 & 28.67 & 83.50 \\
\hline KT06-17 & $\operatorname{ccc}$ & 1 & 3 & $\mathrm{~d} 040$ & 4.80 & 12.5 & 17.8 & 51.4 & 8.00 & 20.83 & 29.67 & 85.67 \\
\hline blank & ref & 1 & 4 & d092 & 0.116 & $<1.00$ & 4.01 & $<0.100$ & 0.19 & 0.83 & 6.68 & 0.08 \\
\hline KT06-11 & quenched & 1 & 5 & $\mathrm{~d} 088$ & 9.32 & 9.11 & 18.3 & 56.1 & 15.53 & 15.18 & 30.50 & 93.50 \\
\hline KT06-13 & quenched & 1 & 6 & $\mathrm{~d} 050$ & 7.93 & 10.0 & 15.8 & 54.7 & 13.22 & 16.67 & 26.33 & 91.17 \\
\hline KT06-01 & $\mathrm{ccc}$ & 1 & 7 & d111 & 8.14 & 6.27 & 33.5 & 52.8 & 13.57 & 10.45 & 55.83 & 88.00 \\
\hline KT06-15 & quenched & 1 & 8 & $\mathrm{~d} 090$ & 5.23 & 14.6 & 20.3 & 60.7 & 8.72 & 24.33 & 33.83 & 101.17 \\
\hline KT06-09 & $\mathrm{ccc}$ & 1 & 9 & d103 & 5.81 & 12.7 & 30.2 & 72.6 & 9.68 & 21.17 & 50.33 & 121.00 \\
\hline KT06-07 & ccc & 1 & 10 & $\mathrm{~d} 057$ & 6.46 & 6.59 & 14.3 & 44.0 & 10.77 & 10.98 & 23.83 & 73.33 \\
\hline KT06-03 & $\mathrm{ccc}$ & 1 & 11 & $\mathrm{~d} 086$ & 5.09 & 9.95 & 43.1 & 67.9 & 8.48 & 16.58 & 71.83 & 113.17 \\
\hline Soln Std & ref & 1 & 12 & std-12 & 19.5 & 9.85 & 82.3 & 51.1 & 19.50 & 9.85 & 82.30 & 51.10 \\
\hline KT06-03 & quenched & 1 & 13 & $\mathrm{~d} 013$ & 5.67 & 10.1 & 43.9 & 69.4 & 9.45 & 16.83 & 73.17 & 115.67 \\
\hline KT06-05 & $\mathrm{ccc}$ & 1 & 14 & d113 & 7.56 & 7.59 & 18.0 & 52.2 & 12.60 & 12.65 & 30.00 & 87.00 \\
\hline KT06-13 & $\mathrm{ccc}$ & 1 & 15 & $\mathrm{~d} 003$ & 8.09 & 9.79 & 16.6 & 56.5 & 13.48 & 16.32 & 27.67 & 94.17 \\
\hline KT06-05 & quenched & 1 & 16 & $\mathrm{~d} 067$ & 7.58 & 7.78 & 16.7 & 50.3 & 12.63 & 12.97 & 27.83 & 83.84 \\
\hline KT06-09 & quenched & 1 & 17 & $\mathrm{~d} 079$ & 5.78 & 12.7 & 30.6 & 72.6 & 9.63 & 21.17 & 51.00 & 121.00 \\
\hline KT06-11 & $\mathrm{ccc}$ & 1 & 18 & $\mathrm{~d} 110$ & 8.04 & 8.84 & 20.9 & 59.2 & 13.40 & 14.73 & 34.83 & 98.67 \\
\hline KT06-07 & quenched & 1 & 19 & $\mathrm{~d} 063$ & 6.95 & 7.62 & 15.5 & 46.3 & 11.58 & 12.70 & 25.83 & 77.17 \\
\hline KT06-01 & quenched & 1 & 20 & $\mathrm{~d} 020$ & 8.02 & 6.44 & 34.1 & 54.7 & 13.37 & 10.73 & 56.83 & 91.17 \\
\hline KT06-15 & $\mathrm{ccc}$ & 1 & 21 & $\mathrm{~d} 085$ & 4.88 & 14.4 & 21.0 & 62.3 & 8.13 & 24.00 & 35.00 & 103.84 \\
\hline EA & ref & 1 & 22 & $\mathrm{~d} 054$ & 22.0 & 7.67 & 65.9 & 39.3 & 366.67 & 127.83 & 1098.34 & 655.00 \\
\hline Soln Std & ref & 1 & 23 & std-13 & 19.4 & 9.85 & 83.3 & 49.8 & 19.40 & 9.85 & 83.30 & 49.80 \\
\hline Soln Std & ref & 2 & 1 & std-21 & 20.9 & 10.0 & 84.5 & 51.8 & 20.90 & 10.00 & 84.50 & 51.80 \\
\hline KT06-17 & $\mathrm{ccc}$ & 2 & 2 & $\mathrm{~d} 048$ & 5.09 & 12.1 & 17.3 & 51.0 & 8.48 & 20.17 & 28.83 & 85.00 \\
\hline EA & ref & 2 & 3 & $\mathrm{~d} 021$ & 22.5 & 7.87 & 66.6 & 41.1 & 375.00 & 131.17 & 1110.00 & 685.00 \\
\hline KT06-15 & $\mathrm{ccc}$ & 2 & 4 & $\mathrm{~d} 008$ & 5.21 & 14.3 & 21.8 & 63.4 & 8.68 & 23.83 & 36.33 & 105.67 \\
\hline KT06-01 & ccc & 2 & 5 & $\mathrm{~d} 024$ & 8.28 & 6.37 & 38.0 & 55.0 & 13.80 & 10.62 & 63.33 & 91.67 \\
\hline KT06-15 & quenched & 2 & 6 & $\mathrm{~d} 036$ & 5.39 & 15.1 & 20.9 & 64.4 & 8.98 & 25.17 & 34.83 & 107.34 \\
\hline KT06-07 & quenched & 2 & 7 & d112 & 7.01 & 7.45 & 15.6 & 46.1 & 11.68 & 12.42 & 26.00 & 76.83 \\
\hline KT06-11 & $\mathrm{ccc}$ & 2 & 8 & $\mathrm{~d} 068$ & 8.15 & 9.09 & 19.8 & 61.3 & 13.58 & 15.15 & 33.00 & 102.17 \\
\hline KT06-03 & quenched & 2 & 9 & $\mathrm{~d} 075$ & 5.30 & 10.2 & 44.9 & 71.3 & 8.83 & 17.00 & 74.83 & 118.84 \\
\hline KT06-09 & quenched & 2 & 10 & $\mathrm{~d} 058$ & 5.87 & 12.8 & 30.5 & 75.3 & 9.78 & 21.33 & 50.83 & 125.50 \\
\hline KT06-11 & quenched & 2 & 11 & $\mathrm{~d} 023$ & 8.87 & 8.97 & 18.9 & 56.9 & 14.78 & 14.95 & 31.50 & 94.84 \\
\hline Soln Std & ref & 2 & 12 & std-22 & 20.1 & 10.0 & 83.3 & 51.8 & 20.10 & 10.00 & 83.30 & 51.80 \\
\hline KT06-01 & quenched & 2 & 13 & $\mathrm{~d} 005$ & 8.35 & 6.38 & 33.4 & 54.7 & 13.92 & 10.63 & 55.67 & 91.17 \\
\hline KT06-05 & $\mathrm{ccc}$ & 2 & 14 & $\mathrm{~d} 044$ & 7.46 & 7.39 & 18.8 & 51.7 & 12.43 & 12.32 & 31.33 & 86.17 \\
\hline KT06-07 & $\mathrm{ccc}$ & 2 & 15 & $\mathrm{~d} 073$ & 6.47 & 6.59 & 14.9 & 45.3 & 10.78 & 10.98 & 24.83 & 75.50 \\
\hline KT06-09 & ccc & 2 & 16 & d004 & 5.77 & 12.7 & 28.8 & 74.8 & 9.62 & 21.17 & 48.00 & 124.67 \\
\hline KT06-13 & quenched & 2 & 17 & $\mathrm{~d} 026$ & 7.57 & 10.0 & 16.6 & 56.5 & 12.62 & 16.67 & 27.67 & 94.17 \\
\hline KT06-13 & $\mathrm{ccc}$ & 2 & 18 & d089 & 7.62 & 9.76 & 17.0 & 57.9 & 12.70 & 16.27 & 28.33 & 96.50 \\
\hline KT06-17 & quenched & 2 & 19 & $\mathrm{~d} 082$ & 4.26 & 12.6 & 17.0 & 51.6 & 7.10 & 21.00 & 28.33 & 86.00 \\
\hline KT06-05 & quenched & 2 & 20 & $\mathrm{~d} 105$ & 7.41 & 8.09 & 19.6 & 53.7 & 12.35 & 13.48 & 32.67 & 89.50 \\
\hline KT06-03 & $\mathrm{ccc}$ & 2 & 21 & $\mathrm{~d} 038$ & 4.93 & 10.0 & 43.1 & 70.1 & 8.22 & 16.67 & 71.83 & 116.84 \\
\hline Soln Std & ref & 2 & 22 & std-33 & 19.6 & 10.1 & 86.6 & 52.2 & 19.60 & 10.10 & 86.60 & 52.20 \\
\hline Soln Std & ref & 3 & 1 & std-31 & 19.0 & 9.85 & 81.1 & 49.0 & 19.00 & 9.85 & 81.10 & 49.00 \\
\hline KT06-17 & quenched & 3 & 2 & $\mathrm{~d} 104$ & 2.86 & 12.7 & 17.2 & 49.5 & 4.77 & 21.17 & 28.67 & 82.50 \\
\hline KT06-03 & quenched & 3 & 3 & $\mathrm{~d} 081$ & 3.73 & 10.2 & 44.2 & 69.3 & 6.22 & 17.00 & 73.67 & 115.50 \\
\hline KT06-09 & quenched & 3 & 4 & d039 & 4.01 & 12.5 & 30.4 & 71.1 & 6.68 & 20.83 & 50.67 & 118.50 \\
\hline KT06-07 & quenched & 3 & 5 & $\mathrm{~d} 041$ & 5.25 & 7.44 & 14.8 & 43.1 & 8.75 & 12.40 & 24.67 & 71.83 \\
\hline KT06-03 & $\mathrm{ccc}$ & 3 & 6 & d049 & 3.41 & 9.90 & 43.0 & 66.1 & 5.68 & 16.50 & 71.67 & 110.17 \\
\hline KT06-13 & quenched & 3 & 7 & $\mathrm{~d} 070$ & 5.75 & 10.1 & 16.9 & 52.6 & 9.58 & 16.83 & 28.17 & 87.67 \\
\hline KT06-15 & $\mathrm{ccc}$ & 3 & 8 & $\mathrm{~d} 102$ & 3.32 & 14.3 & 21.8 & 60.1 & 5.53 & 23.83 & 36.33 & 100.17 \\
\hline KT06-05 & $\mathrm{ccc}$ & 3 & 9 & d107 & 5.31 & 7.34 & 17.4 & 47.8 & 8.85 & 12.23 & 29.00 & 79.67 \\
\hline KT06-15 & quenched & 3 & 10 & $\mathrm{~d} 016$ & 3.34 & 14.6 & 23.4 & 59.8 & 5.57 & 24.33 & 39.00 & 99.67 \\
\hline KT06-01 & $\mathrm{ccc}$ & 3 & 11 & $\mathrm{~d} 017$ & 5.75 & 6.08 & 32.4 & 49.3 & 9.58 & 10.13 & 54.00 & 82.17 \\
\hline Soln Std & ref & 3 & 12 & std-32 & 17.6 & 9.60 & 79.1 & 46.7 & 17.60 & 9.60 & 79.10 & 46.70 \\
\hline KT06-13 & $\mathrm{ccc}$ & 3 & 13 & d097 & 6.43 & 9.87 & 18.5 & 54.6 & 10.72 & 16.45 & 30.83 & 91.00 \\
\hline КT06-17 & $\mathrm{ccc}$ & 3 & 14 & d019 & 2.53 & 12.0 & 16.8 & 46.3 & 4.22 & 20.00 & 28.00 & 77.17 \\
\hline
\end{tabular}


Table B-1. Measurements of the PCT Solutions for the KT06-Series Glasses As-Received (ar) and After Appropriate Adjustments (ppm). (continued)

\begin{tabular}{|c|c|c|c|c|c|c|c|c|c|c|c|c|}
\hline Glass ID & Heat Treatment & Block & Seq & Lab ID & B (ar) & Li (ar) & Na (ar) & Si (ar) & B (ppm) & Li (ppm) & Na (ppm) & Si (ppm) \\
\hline KT06-05 & \begin{tabular}{|c|} 
quenched \\
\end{tabular} & 3 & 15 & $\mathrm{~d} 018$ & 5.84 & 7.99 & 16.9 & 48.9 & 9.73 & 13.32 & 28.17 & 81.50 \\
\hline KT06-11 & $\mathrm{ccc}$ & 3 & 16 & d047 & 6.51 & 9.11 & 19.4 & 57.3 & 10.85 & 15.18 & 32.33 & 95.50 \\
\hline EA & ref & 3 & 17 & $\mathrm{~d} 022$ & 29.8 & 9.91 & 88.7 & 44.9 & 496.67 & 165.17 & 1478.34 & 748.33 \\
\hline KT06-07 & $\mathrm{ccc}$ & 3 & 18 & $\mathrm{~d} 055$ & 4.88 & 6.60 & 15.1 & 40.7 & 8.13 & 11.00 & 25.17 & 67.83 \\
\hline KT06-11 & quenched & 3 & 19 & $\mathrm{~d} 032$ & 7.27 & 8.91 & 18.0 & 51.9 & 12.12 & 14.85 & 30.00 & 86.50 \\
\hline KT06-09 & $\mathrm{ccc}$ & 3 & 20 & d091 & 4.14 & 13.1 & 31.2 & 73.0 & 6.90 & 21.83 & 52.00 & 121.67 \\
\hline KT06-01 & quenched & 3 & 21 & $\mathrm{~d} 011$ & 6.16 & 6.38 & 34.4 & 50.1 & 10.27 & 10.63 & 57.33 & 83.50 \\
\hline Soln Std & ref & 3 & 22 & std-33 & 17.8 & 9.69 & 81.4 & 45.7 & 17.80 & 9.69 & 81.40 & 45.70 \\
\hline Soln Std & ref & 4 & 1 & std-41 & 21.2 & 9.81 & 80.5 & 50.7 & 21.20 & 9.81 & 80.50 & 50.70 \\
\hline KT06-16 & $\mathrm{ccc}$ & 4 & 2 & $\mathrm{~d} 046$ & 5.84 & 12.7 & 21.2 & 67.9 & 9.73 & 21.17 & 35.33 & 113.17 \\
\hline KT06-18 & quenched & 4 & 3 & d099 & 5.32 & 9.24 & 19.4 & 58.7 & 8.87 & 15.40 & 32.33 & 97.84 \\
\hline ARM-1 & ref & 4 & 4 & $\mathrm{~d} 066$ & 9.81 & 7.79 & 21.6 & 34.8 & 16.35 & 12.98 & 36.00 & 58.00 \\
\hline KT06-06 & $\mathrm{ccc}$ & 4 & 5 & d108 & 8.70 & 8.08 & 20.1 & 55.1 & 14.50 & 13.47 & 33.50 & 91.84 \\
\hline KT06-16 & quenched & 4 & 6 & $\mathrm{~d} 095$ & 5.34 & 13.3 & 21.2 & 69.5 & 8.90 & 22.17 & 35.33 & 115.84 \\
\hline KT06-14 & quenched & 4 & 7 & $\mathrm{~d} 002$ & 7.62 & 10.0 & 14.2 & 43.6 & 12.70 & 16.67 & 23.67 & 72.67 \\
\hline KT06-12 & $\mathrm{ccc}$ & 4 & 8 & d115 & 8.72 & 10.5 & 19.4 & 52.2 & 14.53 & 17.50 & 32.33 & 87.00 \\
\hline KT06-12 & quenched & 4 & 9 & $\mathrm{~d} 093$ & 9.01 & 11.2 & 19.1 & 52.7 & 15.02 & 18.67 & 31.83 & 87.84 \\
\hline KT06-04 & $\mathrm{ccc}$ & 4 & 10 & $\mathrm{~d} 069$ & 3.93 & 7.62 & 28.3 & 51.1 & 6.55 & 12.70 & 47.17 & 85.17 \\
\hline KT06-06 & quenched & 4 & 11 & $\begin{array}{l}\mathrm{d} 098 \\
\end{array}$ & 8.51 & 8.20 & 19.6 & 53.4 & 14.18 & 13.67 & 32.67 & 89.00 \\
\hline Soln Std & ref & 4 & 12 & std-42 & 19.0 & 9.70 & 80.1 & 49.2 & 19.00 & 9.70 & 80.10 & 49.20 \\
\hline KT06-10 & quenched & 4 & 13 & $\mathrm{~d} 078$ & 5.06 & 10.7 & 27.1 & 59.0 & 8.43 & 17.83 & 45.17 & 98.34 \\
\hline KT06-08 & $\mathrm{ccc}$ & 4 & 14 & $\mathrm{~d} 042$ & 5.23 & 11.4 & 24.0 & 67.0 & 8.72 & 19.00 & 40.00 & 111.67 \\
\hline KT06-10 & $\mathrm{ccc}$ & 4 & 15 & $\mathrm{~d} 014$ & 5.04 & 11.0 & 28.8 & 62.2 & 8.40 & 18.33 & 48.00 & 103.67 \\
\hline KT06-18 & $\mathrm{ccc}$ & 4 & 16 & d096 & 4.91 & 9.22 & 20.4 & 61.4 & 8.18 & 15.37 & 34.00 & 102.34 \\
\hline KT06-14 & $\mathrm{ccc}$ & 4 & 17 & $\mathrm{~d} 084$ & 6.75 & 9.46 & 14.0 & 42.7 & 11.25 & 15.77 & 23.33 & 71.17 \\
\hline KT06-02 & quenched & 4 & 18 & $\mathrm{~d} 060$ & 7.30 & 5.85 & 30.1 & 47.6 & 12.17 & 9.75 & 50.17 & 79.33 \\
\hline KT06-02 & $\mathrm{ccc}$ & 4 & 19 & d116 & 6.69 & 5.26 & 28.7 & 46.0 & 11.15 & 8.77 & 47.83 & 76.67 \\
\hline KT06-04 & quenched & 4 & 20 & $\mathrm{~d} 100$ & 4.84 & 8.85 & 28.5 & 56.6 & 8.07 & 14.75 & 47.50 & 94.34 \\
\hline KT06-08 & quenched & 4 & 21 & d064 & 5.04 & 10.7 & 21.8 & 63.1 & 8.40 & 17.83 & 36.33 & 105.17 \\
\hline Soln Std & ref & 4 & 22 & std-43 & 19.7 & 9.79 & 81.2 & 49.6 & 19.70 & 9.79 & 81.20 & 49.60 \\
\hline Soln Std & ref & 5 & 1 & std-51 & 19.9 & 10.0 & 80.3 & 50.3 & 19.90 & 10.00 & 80.30 & 50.30 \\
\hline KT06-12 & quenched & 5 & 2 & $\mathrm{~d} 074$ & 9.19 & 11.7 & 19.4 & 55.6 & 15.32 & 19.50 & 32.33 & 92.67 \\
\hline KT06-08 & $\mathrm{ccc}$ & 5 & 3 & $\mathrm{~d} 071$ & 5.34 & 11.8 & 22.3 & 70.1 & 8.90 & 19.67 & 37.17 & 116.84 \\
\hline KT06-02 & $\mathrm{ccc}$ & 5 & 4 & $\mathrm{~d} 001$ & 6.69 & 5.46 & 28.7 & 47.0 & 11.15 & 9.10 & 47.83 & 78.33 \\
\hline KT06-04 & $\mathrm{ccc}$ & 5 & 5 & d053 & 3.86 & 8.03 & 25.6 & 52.9 & 6.43 & 13.38 & 42.67 & 88.17 \\
\hline KT06-16 & $\mathrm{ccc}$ & 5 & 6 & $\mathrm{~d} 012$ & 5.08 & 13.3 & 22.0 & 70.3 & 8.47 & 22.17 & 36.67 & 117.17 \\
\hline KT06-02 & quenched & 5 & 7 & $\mathrm{~d} 034$ & 7.51 & 6.22 & 31.7 & 49.5 & 12.52 & 10.37 & 52.83 & 82.50 \\
\hline KT06-18 & $\mathrm{ccc}$ & 5 & 8 & d006 & 4.94 & 9.78 & 22.1 & 64.1 & 8.23 & 16.30 & 36.83 & 106.84 \\
\hline KT06-14 & quenched & 5 & 9 & d114 & 7.45 & 10.4 & 14.7 & 44.6 & 12.42 & 17.33 & 24.50 & 74.33 \\
\hline ARM-1 & ref & 5 & 10 & $\mathrm{~d} 065$ & 9.94 & 8.39 & 21.3 & 36.9 & 16.57 & 13.98 & 35.50 & 61.50 \\
\hline KT06-04 & quenched & 5 & 11 & $\mathrm{~d} 101$ & 4.86 & 9.42 & 28.5 & 59.3 & 8.10 & 15.70 & 47.50 & 98.84 \\
\hline Soln Std & ref & 5 & 12 & std-52 & 20.0 & 10.3 & 82.4 & 51.5 & 20.00 & 10.30 & 82.40 & 51.50 \\
\hline KT06-18 & quenched & 5 & 13 & d109 & 5.46 & 10.0 & 18.5 & 62.0 & 9.10 & 16.67 & 30.83 & 103.34 \\
\hline KT06-10 & quenched & 5 & 14 & $\mathrm{~d} 035$ & 5.22 & 12.0 & 29.0 & 64.9 & 8.70 & 20.00 & 48.33 & 108.17 \\
\hline KT06-10 & $\mathrm{ccc}$ & 5 & 15 & d077 & 4.86 & 11.0 & 26.5 & 61.5 & 8.10 & 18.33 & 44.17 & 102.50 \\
\hline KT06-06 & $\mathrm{ccc}$ & 5 & 16 & $\mathrm{~d} 072$ & 8.38 & 8.43 & 21.9 & 56.3 & 13.97 & 14.05 & 36.50 & 93.84 \\
\hline KT06-12 & $\mathrm{ccc}$ & 5 & 17 & d056 & 8.35 & 10.9 & 17.7 & 53.0 & 13.92 & 18.17 & 29.50 & 88.34 \\
\hline KT06-08 & quenched & 5 & 18 & $\mathrm{~d} 015$ & 5.03 & 11.6 & 23.3 & 66.9 & 8.38 & 19.33 & 38.83 & 111.50 \\
\hline KT06-14 & $\mathrm{ccc}$ & 5 & 19 & $\mathrm{~d} 083$ & 7.09 & 10.4 & 14.2 & 45.8 & 11.82 & 17.33 & 23.67 & 76.33 \\
\hline KT06-16 & quenched & 5 & 20 & $\mathrm{~d} 025$ & 5.23 & 14.3 & 22.1 & 73.5 & 8.72 & 23.83 & 36.83 & 122.50 \\
\hline KT06-06 & quenched & 5 & 21 & $\mathrm{~d} 087$ & 8.47 & 8.62 & 19.9 & 54.8 & 14.12 & 14.37 & 33.17 & 91.34 \\
\hline Soln Std & ref & 5 & 22 & std-53 & 20.1 & 10.5 & 81.2 & 52.1 & 20.10 & 10.50 & 81.20 & 52.10 \\
\hline Soln Std & ref & 6 & 1 & std-61 & 19.6 & 9.86 & 79.9 & 50.4 & 19.60 & 9.86 & 79.90 & 50.40 \\
\hline KT06-12 & quenched & 6 & 2 & d059 & 8.69 & 11.1 & 18.5 & 52.6 & 14.48 & 18.50 & 30.83 & 87.67 \\
\hline KT06-04 & $\mathrm{ccc}$ & 6 & 3 & d076 & 3.64 & 7.98 & 27.1 & 53.2 & 6.07 & 13.30 & 45.17 & 88.67 \\
\hline KT06-14 & $\mathrm{ccc}$ & 6 & 4 & d045 & 6.59 & 10.0 & 13.5 & 45.1 & 10.98 & 16.67 & 22.50 & 75.17 \\
\hline KT06-06 & quenched & 6 & 5 & d051 & 8.07 & 8.20 & 18.8 & 53.8 & 13.45 & 13.67 & 31.33 & 89.67 \\
\hline KT06-18 & quenched & 6 & 6 & d007 & 4.65 & 9.66 & 18.1 & 60.8 & 7.75 & 16.10 & 30.17 & 101.34 \\
\hline KT06-02 & $\mathrm{ccc}$ & 6 & 7 & d031 & 6.01 & 5.31 & 28.0 & 45.7 & 10.02 & 8.85 & 46.67 & 76.17 \\
\hline KT06-02 & quenched & 6 & 8 & d052 & 7.04 & 6.04 & 29.8 & 48.9 & 11.73 & 10.07 & 49.67 & 81.50 \\
\hline
\end{tabular}


Table B-1. Measurements of the PCT Solutions for the KT06-Series Glasses As-Received (ar) and After Appropriate Adjustments (ppm). (continued)

\begin{tabular}{|c|c|c|c|c|c|c|c|c|c|c|c|c|}
\hline Glass ID & Heat Treatment & Block & Seq & Lab ID & B (ar) & Li (ar) & Na (ar) & Si (ar) & B (ppm) & Li (ppm) & $\mathrm{Na}(\mathrm{ppm})$ & Si (ppm) \\
\hline KT06-16 & quenched & 6 & 9 & d094 & 5.51 & 15.3 & 42.2 & 78.7 & 9.18 & 25.50 & 70.33 & 131.17 \\
\hline KT06-14 & quenched & 6 & 10 & $\mathrm{~d} 037$ & 7.38 & 10.7 & 15.7 & 46.2 & 12.30 & 17.83 & 26.17 & 77.00 \\
\hline KT06-12 & $\mathrm{ccc}$ & 6 & 11 & $\mathrm{~d} 029$ & 7.89 & 10.5 & 19.0 & 51.8 & 13.15 & 17.50 & 31.67 & 86.34 \\
\hline Soln Std & ref & 6 & 12 & std-62 & 19.6 & 10.1 & 83.3 & 51.1 & 19.60 & 10.10 & 83.30 & 51.10 \\
\hline KT06-08 & quenched & 6 & 13 & $\mathrm{~d} 027$ & 5.38 & 11.0 & 21.3 & 64.3 & 8.97 & 18.33 & 35.50 & 107.17 \\
\hline KT06-16 & $\mathrm{ccc}$ & 6 & 14 & $\mathrm{~d} 080$ & 4.82 & 13.1 & 20.7 & 69.7 & 8.03 & 21.83 & 34.50 & 116.17 \\
\hline KT06-10 & quenched & 6 & 15 & $\mathrm{~d} 062$ & 4.35 & 11.1 & 28.4 & 61.7 & 7.25 & 18.50 & 47.33 & 102.84 \\
\hline KT06-10 & $\mathrm{ccc}$ & 6 & 16 & $\mathrm{~d} 028$ & 4.45 & 10.8 & 27.1 & 61.6 & 7.42 & 18.00 & 45.17 & 102.67 \\
\hline KT06-04 & quenched & 6 & 17 & $\mathrm{~d} 030$ & 4.30 & 9.12 & 28.4 & 58.2 & 7.17 & 15.20 & 47.33 & 97.00 \\
\hline KT06-06 & $\operatorname{ccc}$ & 6 & 18 & $\mathrm{~d} 106$ & 7.65 & 7.81 & 18.9 & 52.9 & 12.75 & 13.02 & 31.50 & 88.17 \\
\hline ARM-1 & ref & 6 & 19 & $\mathrm{~d} 061$ & 9.09 & 8.06 & 20.2 & 35.7 & 15.15 & 13.43 & 33.67 & 59.50 \\
\hline KT06-08 & $\mathrm{ccc}$ & 6 & 20 & $\mathrm{~d} 033$ & 4.96 & 11.9 & 22.5 & 70.5 & 8.27 & 19.83 & 37.50 & 117.50 \\
\hline blank & ref & 6 & 21 & $\mathrm{~d} 009$ & $<0.100$ & $<1.00$ & $<0.100$ & $<0.100$ & 0.08 & 0.83 & 0.08 & 0.08 \\
\hline KT06-18 & ccc & 6 & 22 & $\mathrm{~d} 010$ & 4.22 & 9.62 & 19.0 & 63.0 & 7.03 & 16.03 & 31.67 & 105.00 \\
\hline Soln Std & ref & 6 & 23 & std-63 & 19.7 & 10.1 & 80.8 & 51.3 & 19.70 & 10.10 & 80.80 & 51.30 \\
\hline
\end{tabular}


Table B-2. Normalized PCT Results for the KT06-Series Glasses by Heat Treatment by Compositional View.

\begin{tabular}{|c|c|c|c|c|c|c|c|c|c|c|}
\hline Glass ID & $\begin{array}{c}\text { Heat } \\
\text { Treatment }\end{array}$ & $\begin{array}{l}\text { Comp } \\
\text { View }\end{array}$ & $\begin{array}{c}\log \text { NL } \\
{[B(g / L)]}\end{array}$ & $\begin{array}{c}\log N L \\
{[\mathrm{Li}(\mathrm{g} / \mathrm{L})]}\end{array}$ & $\begin{array}{c}\log \mathrm{NL} \\
{[\mathrm{Na}(\mathrm{g} / \mathrm{L})]}\end{array}$ & $\begin{array}{c}\log N L \\
{[\mathrm{Si}(\mathrm{g} / \mathrm{L})]}\end{array}$ & $\begin{array}{c}\text { NL } \\
B(g / L)\end{array}$ & $\begin{array}{c}\text { NL } \\
\mathrm{Li}(\mathrm{g} / \mathrm{L})\end{array}$ & $\begin{array}{c}\mathrm{NL} \\
\mathrm{Na}(\mathrm{g} / \mathrm{L})\end{array}$ & $\begin{array}{c}\text { NL } \\
\text { Si (g/L) }\end{array}$ \\
\hline ARM & ref & reference & -0.3408 & -0.2438 & -0.3112 & -0.5616 & 0.456 & 0.570 & 0.488 & 0.274 \\
\hline EA & ref & reference & 1.0662 & 0.8511 & 0.9897 & 0.4845 & 11.647 & 7.097 & 9.765 & 3.051 \\
\hline KT06-01 & $\mathrm{ccc}$ & measured & -0.3176 & -0.1892 & -0.2248 & -0.3920 & 0.481 & 0.647 & 0.596 & 0.406 \\
\hline KT06-02 & ccc & measured & -0.3752 & -0.2572 & -0.3024 & -0.4416 & 0.422 & 0.553 & 0.498 & 0.362 \\
\hline KT06-03 & $\mathrm{ccc}$ & measured & -0.3006 & -0.1173 & -0.1264 & -0.3078 & 0.500 & 0.763 & 0.748 & 0.492 \\
\hline KT06-04 & ccc & measured & -0.3771 & -0.2229 & -0.2832 & -0.4173 & 0.420 & 0.599 & 0.521 & 0.383 \\
\hline KT06-05 & ccc & measured & -0.3639 & -0.1877 & -0.4023 & -0.4081 & 0.433 & 0.649 & 0.396 & 0.391 \\
\hline KT06-06 & $\mathrm{ccc}$ & measured & -0.2810 & -0.1506 & -0.3545 & -0.3851 & 0.524 & 0.707 & 0.442 & 0.412 \\
\hline KT06-07 & $\mathrm{ccc}$ & measured & -0.4075 & -0.2406 & -0.4915 & -0.4717 & 0.391 & 0.575 & 0.322 & 0.338 \\
\hline KT06-08 & $\mathrm{ccc}$ & measured & -0.2375 & -0.1027 & -0.3027 & -0.2989 & 0.579 & 0.789 & 0.498 & 0.502 \\
\hline KT06-09 & $\mathrm{ccc}$ & measured & -0.2394 & -0.0656 & -0.2092 & -0.2681 & 0.576 & 0.860 & 0.618 & 0.539 \\
\hline KT06-10 & $\mathrm{ccc}$ & measured & -0.2823 & -0.1201 & -0.2532 & -0.3303 & 0.522 & 0.758 & 0.558 & 0.467 \\
\hline KT06-11 & $\mathrm{ccc}$ & measured & -0.3135 & -0.1043 & -0.3237 & -0.3400 & 0.486 & 0.786 & 0.475 & 0.457 \\
\hline KT06-12 & ccc & measured & -0.2662 & -0.1372 & -0.3525 & -0.3685 & 0.542 & 0.729 & 0.444 & 0.428 \\
\hline KT06-13 & $\mathrm{ccc}$ & measured & -0.3296 & -0.1713 & -0.3832 & -0.3729 & 0.468 & 0.674 & 0.414 & 0.424 \\
\hline KT06-14 & $\mathrm{ccc}$ & measured & -0.3466 & -0.1710 & -0.4969 & -0.4372 & 0.450 & 0.675 & 0.318 & 0.365 \\
\hline KT06-15 & $\mathrm{ccc}$ & measured & -0.2996 & -0.0949 & -0.3159 & -0.3178 & 0.502 & 0.804 & 0.483 & 0.481 \\
\hline KT06-16 & $\mathrm{ccc}$ & measured & -0.2358 & -0.1450 & -0.3134 & -0.3006 & 0.581 & 0.716 & 0.486 & 0.500 \\
\hline KT06-17 & ccc & measured & -0.3470 & -0.1668 & -0.3960 & -0.4144 & 0.450 & 0.681 & 0.402 & 0.385 \\
\hline KT06-18 & $\mathrm{ccc}$ & measured & -0.2820 & -0.1352 & -0.3217 & -0.3403 & 0.522 & 0.733 & 0.477 & 0.457 \\
\hline KT06-01 & ccc & targeted & -0.3318 & -0.2063 & -0.2306 & -0.4149 & 0.466 & 0.622 & 0.588 & 0.385 \\
\hline KT06-02 & $\mathrm{ccc}$ & targeted & -0.3847 & -0.2737 & -0.3147 & -0.4567 & 0.412 & 0.533 & 0.484 & 0.349 \\
\hline KT06-03 & $\mathrm{ccc}$ & targeted & -0.3074 & -0.1285 & -0.1349 & -0.3219 & 0.493 & 0.744 & 0.733 & 0.477 \\
\hline KT06-04 & $\mathrm{ccc}$ & targeted & -0.3709 & -0.2301 & -0.3380 & -0.4240 & 0.426 & 0.589 & 0.459 & 0.377 \\
\hline KT06-05 & $\mathrm{ccc}$ & targeted & -0.3691 & -0.1968 & -0.4410 & -0.4238 & 0.427 & 0.636 & 0.362 & 0.377 \\
\hline KT06-06 & $\mathrm{ccc}$ & targeted & -0.2791 & -0.1597 & -0.3910 & -0.3889 & 0.526 & 0.692 & 0.406 & 0.408 \\
\hline KT06-07 & $\mathrm{ccc}$ & targeted & -0.4247 & -0.2493 & -0.5285 & -0.4797 & 0.376 & 0.563 & 0.296 & 0.331 \\
\hline KT06-08 & ccc & targeted & -0.2377 & -0.1094 & -0.3374 & -0.3086 & 0.578 & 0.777 & 0.460 & 0.491 \\
\hline KT06-09 & $\mathrm{ccc}$ & targeted & -0.2374 & -0.0692 & -0.2198 & -0.2825 & 0.579 & 0.853 & 0.603 & 0.522 \\
\hline KT06-10 & $\mathrm{ccc}$ & targeted & -0.2724 & -0.1388 & -0.2591 & -0.3472 & 0.534 & 0.726 & 0.551 & 0.450 \\
\hline KT06-11 & $\mathrm{ccc}$ & targeted & -0.3179 & -0.1135 & -0.3107 & -0.3545 & 0.481 & 0.770 & 0.489 & 0.442 \\
\hline KT06-12 & $\mathrm{ccc}$ & targeted & -0.2748 & -0.1509 & -0.3407 & -0.3877 & 0.531 & 0.706 & 0.456 & 0.410 \\
\hline KT06-13 & $\mathrm{ccc}$ & targeted & -0.3285 & -0.1860 & -0.3730 & -0.3824 & 0.469 & 0.652 & 0.424 & 0.415 \\
\hline KT06-14 & $\mathrm{ccc}$ & targeted & -0.3616 & -0.1799 & -0.4693 & -0.4570 & 0.435 & 0.661 & 0.339 & 0.349 \\
\hline KT06-15 & ccc & targeted & -0.3094 & -0.1083 & -0.2792 & -0.3369 & 0.490 & 0.779 & 0.526 & 0.460 \\
\hline KT06-16 & $\mathrm{ccc}$ & targeted & -0.2331 & -0.1497 & -0.2840 & -0.3134 & 0.585 & 0.708 & 0.520 & 0.486 \\
\hline KT06-17 & $\mathrm{ccc}$ & targeted & -0.3545 & -0.1784 & -0.3743 & -0.4332 & 0.442 & 0.663 & 0.422 & 0.369 \\
\hline KT06-18 & $\mathrm{ccc}$ & targeted & -0.2815 & -0.1469 & -0.3013 & -0.3555 & 0.523 & 0.713 & 0.500 & 0.441 \\
\hline KT06-01 & quenched & measured & -0.3086 & -0.1781 & -0.2322 & -0.3853 & 0.491 & 0.664 & 0.586 & 0.412 \\
\hline KT06-02 & quenched & measured & -0.3229 & -0.2043 & -0.2721 & -0.4194 & 0.475 & 0.625 & 0.535 & 0.381 \\
\hline KT06-03 & quenched & measured & -0.2615 & -0.1079 & -0.1138 & -0.2953 & 0.548 & 0.780 & 0.769 & 0.507 \\
\hline KT06-04 & quenched & measured & -0.2895 & -0.1588 & -0.2598 & -0.3730 & 0.513 & 0.694 & 0.550 & 0.424 \\
\hline KT06-05 & quenched & measured & -0.3507 & -0.1587 & -0.4113 & -0.4046 & 0.446 & 0.694 & 0.388 & 0.394 \\
\hline KT06-06 & quenched & measured & -0.2749 & -0.1381 & -0.3728 & -0.3912 & 0.531 & 0.728 & 0.424 & 0.406 \\
\hline KT06-07 & quenched & measured & -0.3748 & -0.1845 & -0.4761 & -0.4535 & 0.422 & 0.654 & 0.334 & 0.352 \\
\hline KT06-08 & quenched & measured & -0.2397 & -0.1258 & -0.3182 & -0.3277 & 0.576 & 0.749 & 0.481 & 0.470 \\
\hline KT06-09 & quenched & measured & -0.2423 & -0.0713 & -0.2027 & -0.2710 & 0.572 & 0.849 & 0.627 & 0.536 \\
\hline KT06-10 & quenched & measured & -0.2746 & -0.1075 & -0.2421 & -0.3299 & 0.531 & 0.781 & 0.573 & 0.468 \\
\hline KT06-11 & quenched & measured & -0.2639 & -0.1051 & -0.3605 & -0.3729 & 0.545 & 0.785 & 0.436 & 0.424 \\
\hline KT06-12 & quenched & measured & -0.2336 & -0.1095 & -0.3454 & -0.3580 & 0.584 & 0.777 & 0.451 & 0.439 \\
\hline KT06-13 & quenched & measured & -0.3496 & -0.1614 & -0.4069 & -0.3865 & 0.447 & 0.690 & 0.392 & 0.411 \\
\hline KT06-14 & quenched & measured & -0.3055 & -0.1532 & -0.4680 & -0.4345 & 0.495 & 0.703 & 0.340 & 0.368 \\
\hline KT06-15 & quenched & measured & -0.2838 & -0.0820 & -0.3167 & -0.3200 & 0.520 & 0.828 & 0.482 & 0.479 \\
\hline KT06-16 & quenched & measured & -0.2252 & -0.1053 & -0.2096 & -0.2732 & 0.595 & 0.785 & 0.617 & 0.533 \\
\hline KT06-17 & quenched & measured & -0.3494 & -0.1527 & -0.4001 & -0.4067 & 0.447 & 0.704 & 0.398 & 0.392 \\
\hline KT06-18 & quenched & measured & -0.2419 & -0.1311 & -0.3617 & -0.3568 & 0.573 & 0.740 & 0.435 & 0.440 \\
\hline KT06-01 & quenched & targeted & -0.3228 & -0.1953 & -0.2380 & -0.4083 & 0.476 & 0.638 & 0.578 & 0.391 \\
\hline KT06-02 & quenched & targeted & -0.3324 & -0.2208 & -0.2844 & -0.4345 & 0.465 & 0.602 & 0.520 & 0.368 \\
\hline KT06-03 & quenched & targeted & -0.2684 & -0.1192 & -0.1223 & -0.3095 & 0.539 & 0.760 & 0.755 & 0.490 \\
\hline KT06-04 & quenched & targeted & -0.2832 & -0.1660 & -0.3147 & -0.3796 & 0.521 & 0.682 & 0.485 & 0.417 \\
\hline KT06-05 & quenched & targeted & -0.3560 & -0.1679 & -0.4501 & -0.4204 & 0.441 & 0.679 & 0.355 & 0.380 \\
\hline KT06-06 & quenched & targeted & -0.2730 & -0.1473 & -0.4093 & -0.3950 & 0.533 & 0.712 & 0.390 & 0.403 \\
\hline KT06-07 & quenched & targeted & -0.3920 & -0.1931 & -0.5131 & -0.4615 & 0.406 & 0.641 & 0.307 & 0.346 \\
\hline KT06-08 & quenched & targeted & -0.2400 & -0.1324 & -0.3529 & -0.3374 & 0.576 & 0.737 & 0.444 & 0.460 \\
\hline KT06-09 & quenched & targeted & -0.2403 & -0.0749 & -0.2134 & -0.2854 & 0.575 & 0.842 & 0.612 & 0.518 \\
\hline KT06-10 & quenched & targeted & -0.2648 & -0.1262 & -0.2481 & -0.3468 & 0.544 & 0.748 & 0.565 & 0.450 \\
\hline KT06-11 & quenched & targeted & -0.2683 & -0.1143 & -0.3475 & -0.3874 & 0.539 & 0.769 & 0.449 & 0.410 \\
\hline
\end{tabular}


Table B-2. Normalized PCT Results for the KT06-Series Glasses by Heat Treatment by Compositional View. (continued)

\begin{tabular}{|c|c|c|c|c|c|c|c|c|c|c|}
\hline Glass ID & $\begin{array}{c}\text { Heat } \\
\text { Treatment }\end{array}$ & $\begin{array}{l}\text { Comp } \\
\text { View }\end{array}$ & $\begin{array}{c}\log N L \\
{[B(g / L)]}\end{array}$ & $\begin{array}{c}\log N L \\
{[\mathrm{Li}(\mathrm{g} / \mathrm{L})]}\end{array}$ & $\begin{array}{c}\log \mathrm{NL} \\
{[\mathrm{Na}(\mathrm{g} / \mathrm{L})]}\end{array}$ & $\begin{array}{c}\log N L \\
{[\mathrm{Si}(\mathrm{g} / \mathrm{L})]}\end{array}$ & $\begin{array}{c}\text { NL } \\
B(g / L)\end{array}$ & $\begin{array}{c}\mathrm{NL} \\
\mathrm{Li}(\mathrm{g} / \mathrm{L})\end{array}$ & $\begin{array}{c}\mathrm{NL} \\
\mathrm{Na}(\mathrm{g} / \mathrm{L})\end{array}$ & $\begin{array}{c}\text { NL } \\
\mathrm{Si}(\mathrm{g} / \mathrm{L})\end{array}$ \\
\hline KT06-12 & quenched & targeted & -0.2422 & -0.1233 & -0.3336 & -0.3771 & 0.572 & 0.753 & 0.464 & 0.420 \\
\hline KT06-13 & quenched & targeted & -0.3486 & -0.1761 & -0.3967 & -0.3960 & 0.448 & 0.667 & 0.401 & 0.402 \\
\hline KT06-14 & quenched & targeted & -0.3205 & -0.1620 & -0.4404 & -0.4544 & 0.478 & 0.689 & 0.363 & 0.351 \\
\hline KT06-15 & quenched & targeted & -0.2936 & -0.0954 & -0.2800 & -0.3391 & 0.509 & 0.803 & 0.525 & 0.458 \\
\hline KT06-16 & quenched & targeted & -0.2225 & -0.1100 & -0.1802 & -0.2860 & 0.599 & 0.776 & 0.660 & 0.518 \\
\hline KT06-17 & quenched & targeted & -0.3569 & -0.1643 & -0.3784 & -0.4255 & 0.440 & 0.685 & 0.418 & 0.375 \\
\hline KT06-18 & quenched & targeted & -0.2414 & -0.1428 & -0.3414 & -0.3720 & 0.574 & 0.720 & 0.456 & 0.425 \\
\hline
\end{tabular}


Exhibit B-1. KT06 PCT Measurements (as Common Logarithms) in Analytical Sequence by Element.

Variability Chart for log[B ppm]
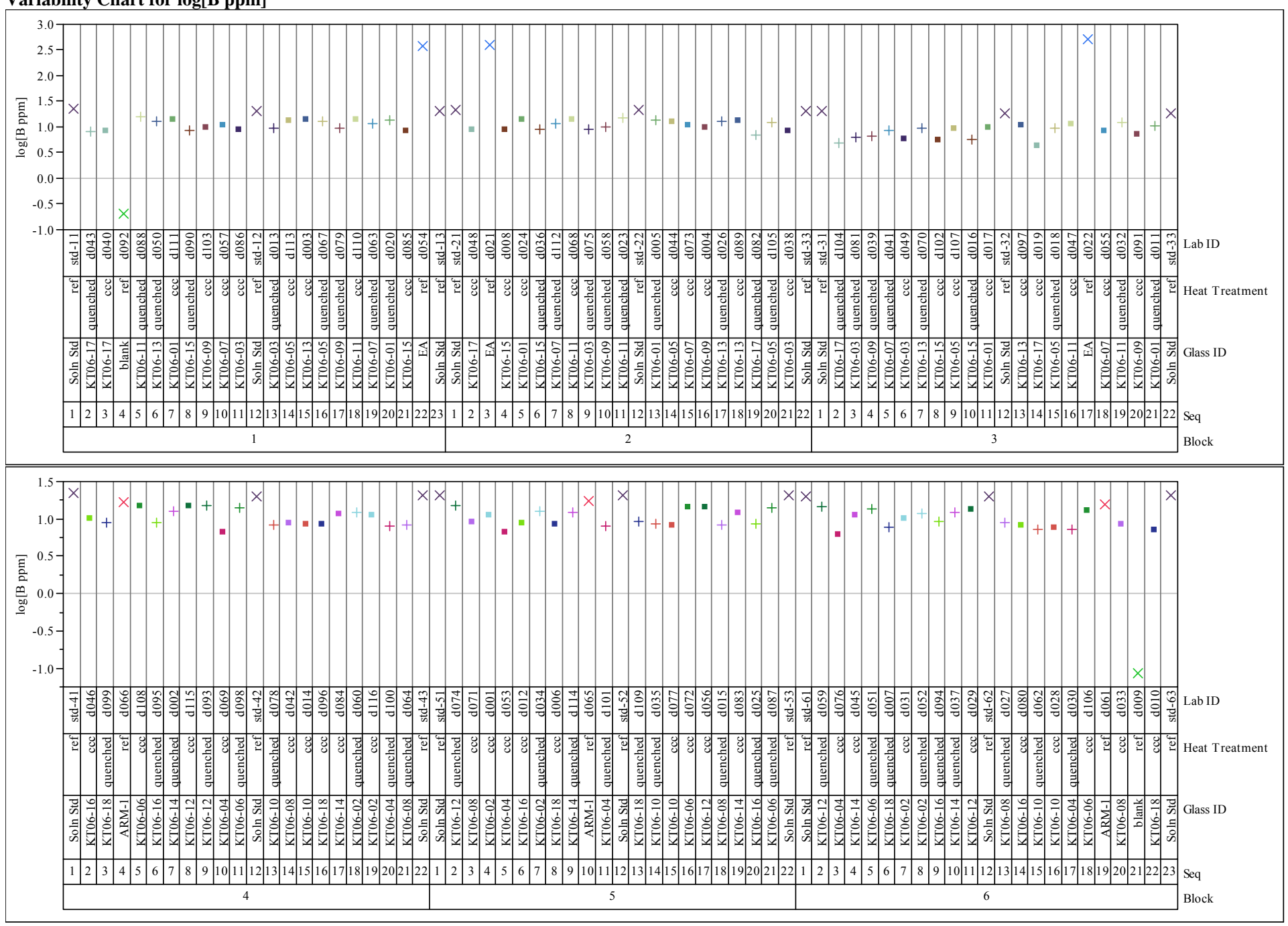
Exhibit B-1. KT06 PCT Measurements (as Common Logarithms) in Analytical Sequence by Element. (continued) Variability Chart for log[Li ppm]
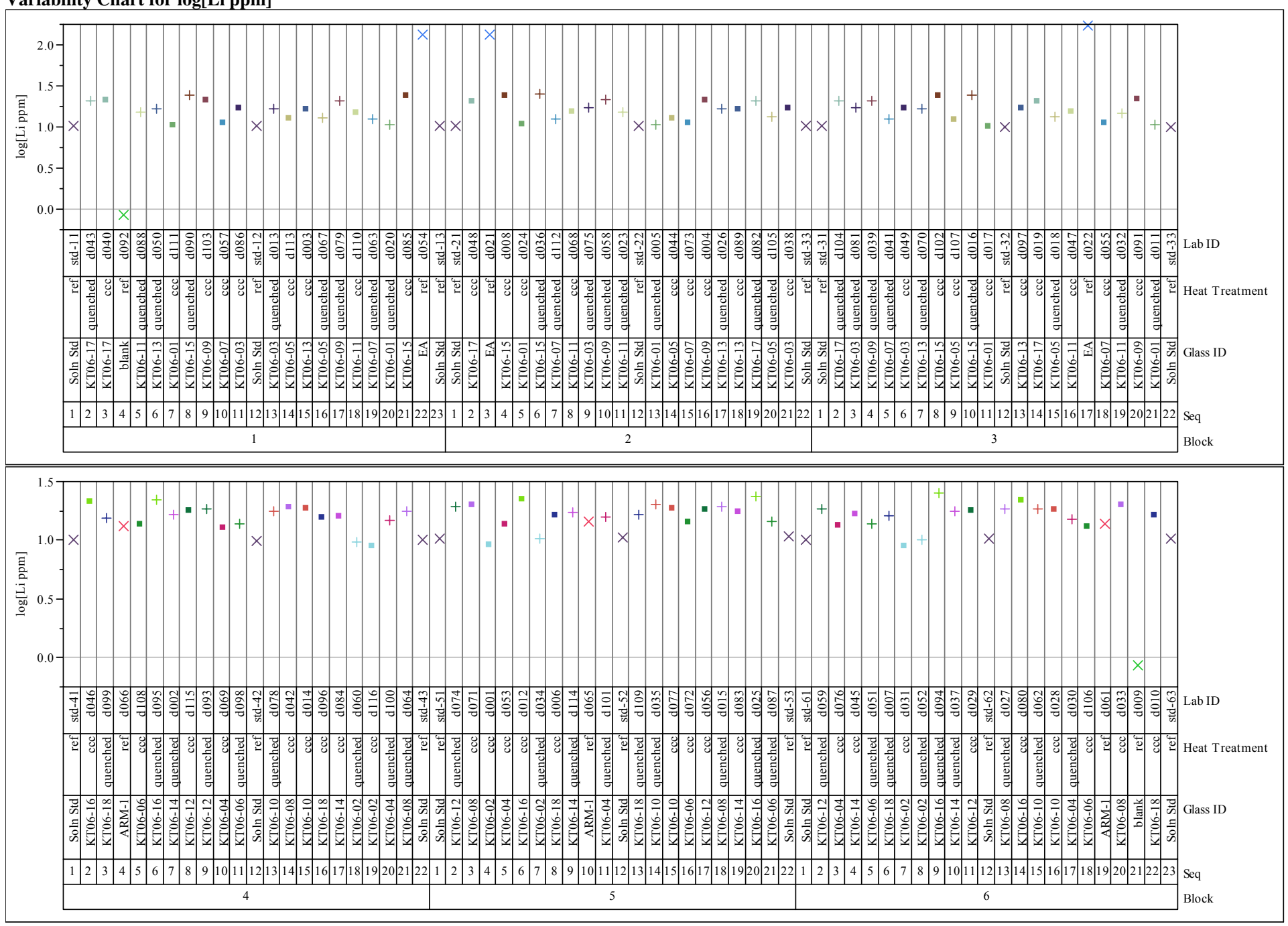
Exhibit B-1. KT06 PCT Measurements (as Common Logarithms) in Analytical Sequence by Element. (continued) Variability Chart for log[Na ppm]
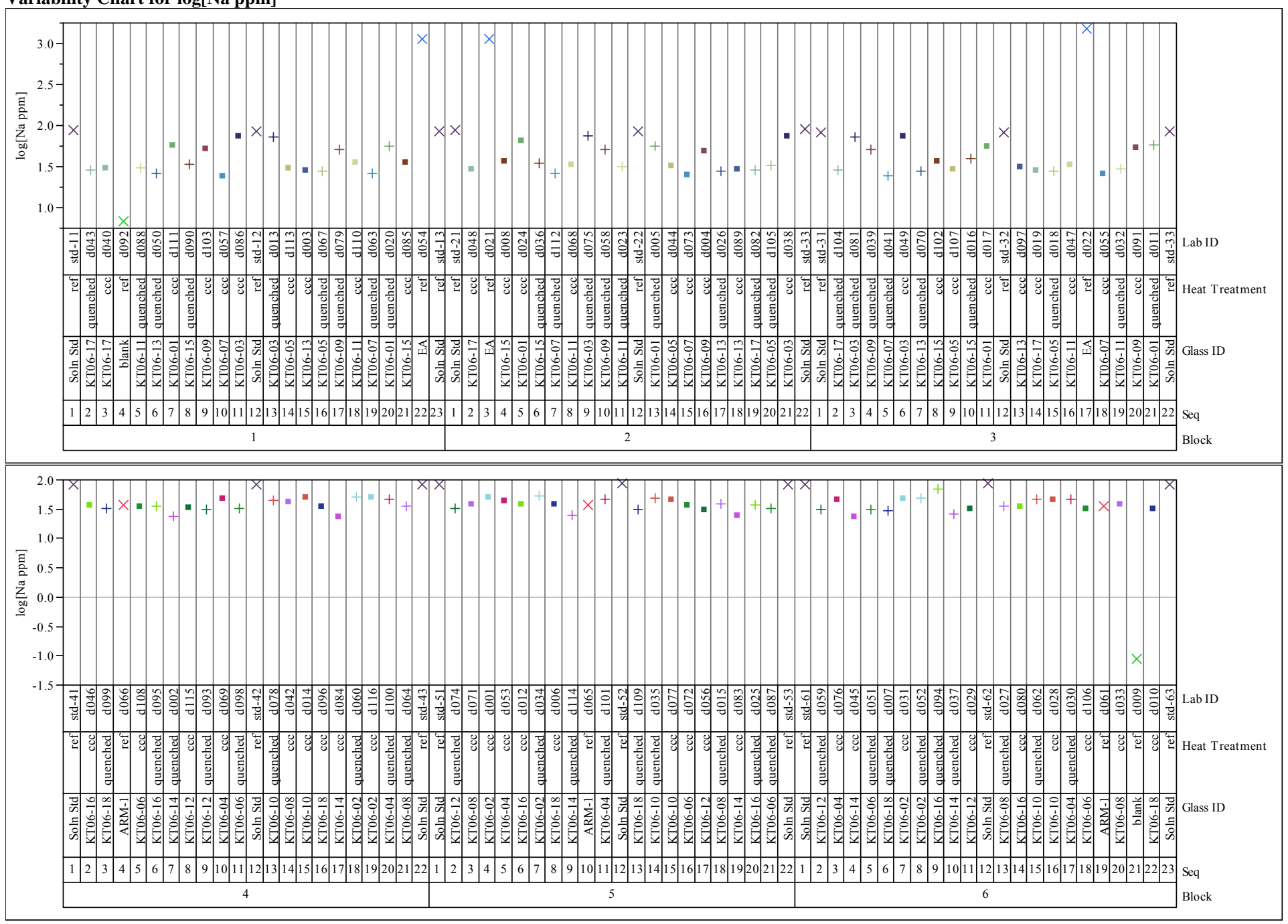
Exhibit B-1. KT06 PCT Measurements (as Common Logarithms) in Analytical Sequence by Element. (continued) Variability Chart for log[Si ppm]
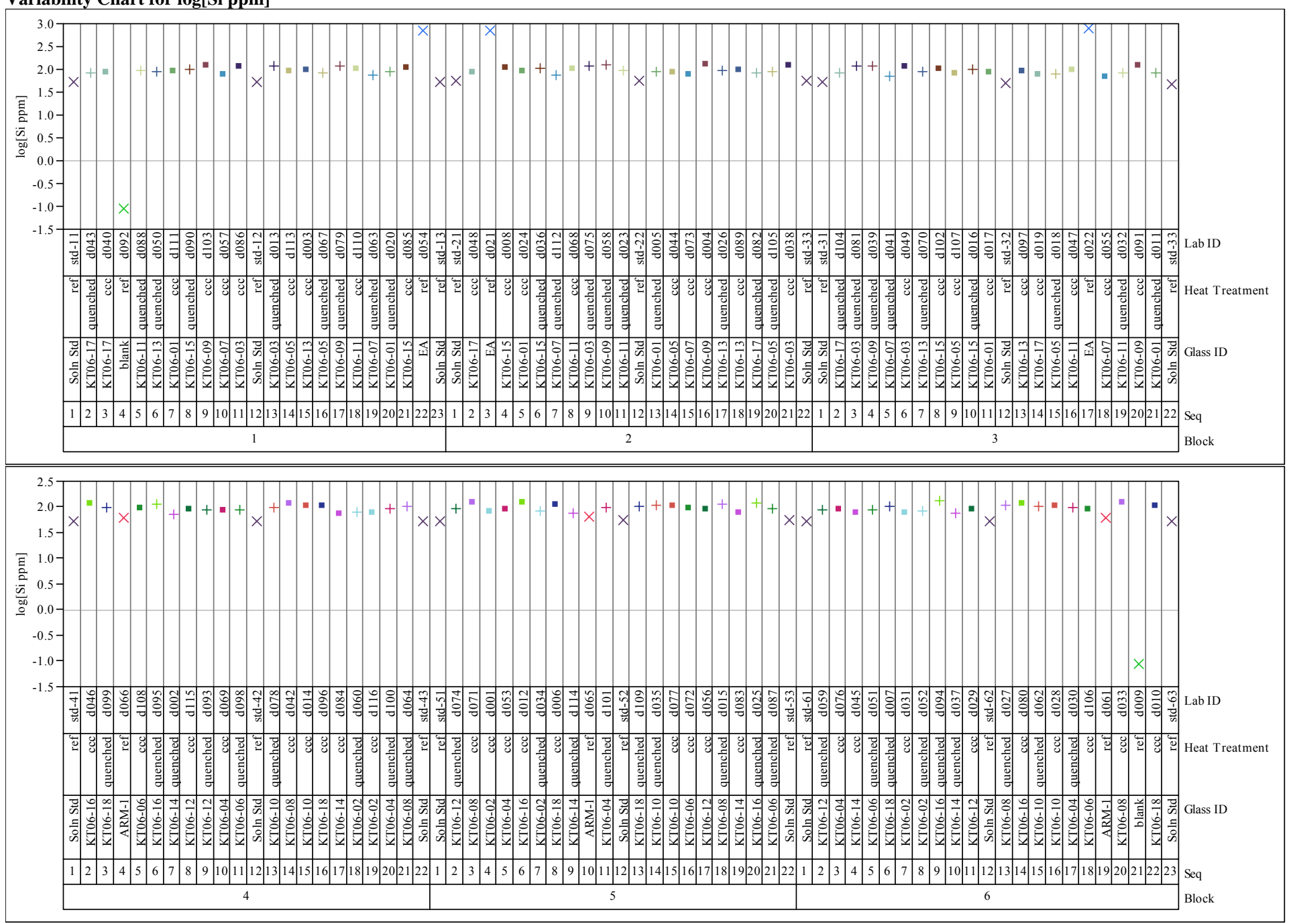
Exhibit B-2. Statistical Evaluation of the ICP-AES Calibration Effects from the Multi-Element Standard Solution Results by Oxide.

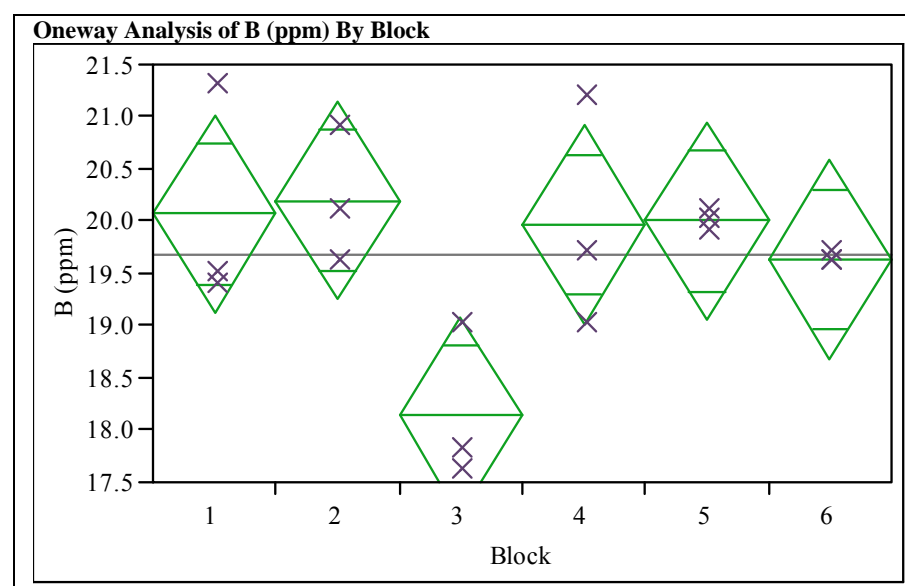

Oneway Anova

Summary of Fit

0.567761

Adj Rsquare $\quad 0.387661$

Root Mean Square Error $\quad 0.755351$

$\begin{array}{lr}\text { Mean of Response } & 19.66667 \\ \text { Observations (or Sum Wgts) } & 18\end{array}$

Analysis of Variance

Source DF Sum of Squares Mean Square F Ratio Prob $>$ F

$\begin{array}{lrrrrr}\text { Block } & 5 & 8.993333 & 1.79867 & 3.1525 & 0.0479\end{array}$

$\begin{array}{lrrr}\text { Error } & 12 & 6.846667 & 0.57056\end{array}$

$\begin{array}{llr}\text { C. Total } & 17 & 15.840000\end{array}$

Means for Oneway Anova

Level Number Mean Std Error Lower 95\% Upper 95\%

$\begin{array}{rrrrrr}1 & 3 & 20.0667 & 0.43610 & 19.116 & 21.017\end{array}$

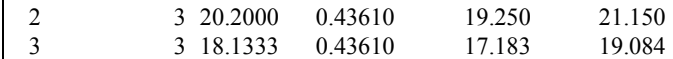

$\begin{array}{llllll}4 & 3 & 19.9667 & 0.43610 & 19.016 & 20.917 \\ 5 & 3 & 20.0000 & 0.43610 & 19.050 & 2.950\end{array}$

$\begin{array}{llllll}5 & 3 & 20.0000 & 0.43610 & 19.050 & 20.950 \\ 6 & 3 & 19.6333 & 0.43610 & 18.683 & 20.584\end{array}$

Std Error uses a pooled estimate of error variance

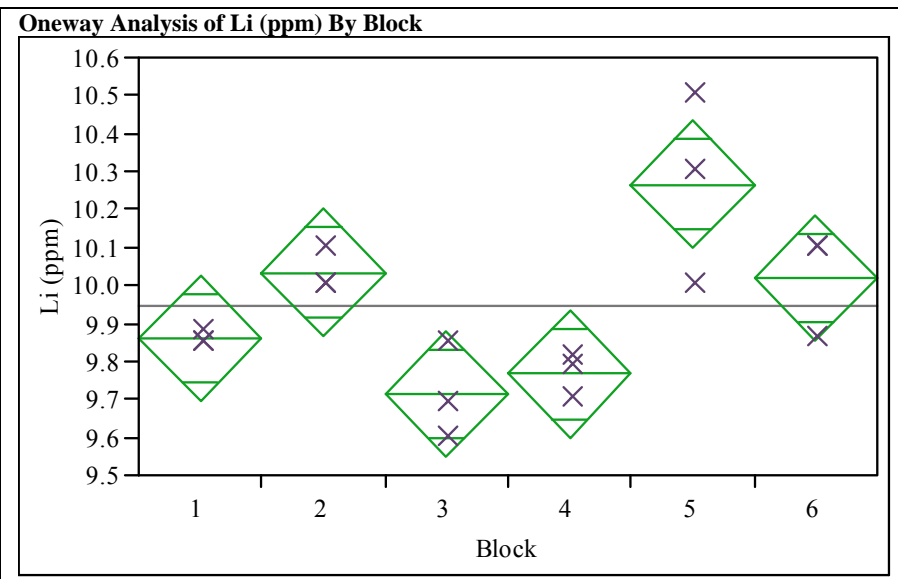

\section{Oneway Anova}

Summary of Fit

\section{Rsquare}

Adj Rsquare $\quad 0.748492$

0.643697

Mean

\begin{tabular}{lr} 
Observations (or Sum Wgts) & 9.943333 \\
\hline
\end{tabular}

Analysis of Variance

Source DF Sum of Squares Mean Square F Ratio Prob > F

$\begin{array}{llllll}\text { Block } & 5 & 0.62873333 & 0.125747 & 7.1424 & 0.0026\end{array}$

$\begin{array}{llll}\text { Error } & 12 & 0.21126667 & 0.017606\end{array}$

C. Total $17 \quad 0.84000000$

Means for Oneway Anova

Level Number Mean Std Error Lower 95\% Upper 95\%

$\begin{array}{lllllr}1 & 3 & 9.8600 & 0.07661 & 9.693 & 10.027\end{array}$

$\begin{array}{rrrrr}3 & 9.8600 & 0.07661 & 9.693 & 10.027 \\ 3 & 10.0333 & 0.07661 & 9.866 & 10.200 \\ 3 & 9.7133 & 0.07661 & 9.546 & 9.880 \\ 3 & 9.7667 & 0.07661 & 9.600 & 9.934 \\ 3 & 10.2667 & 0.07661 & 10.100 & 10.434 \\ 3 & 10.0200 & 0.07661 & 9.853 & 10.187\end{array}$

td Error uses a pooled estimate of error variance 
Exhibit B-2. Statistical Evaluation of the ICP-AES Calibration Effects from the Multi-Element Standard Solution Results by Oxide. (continued)

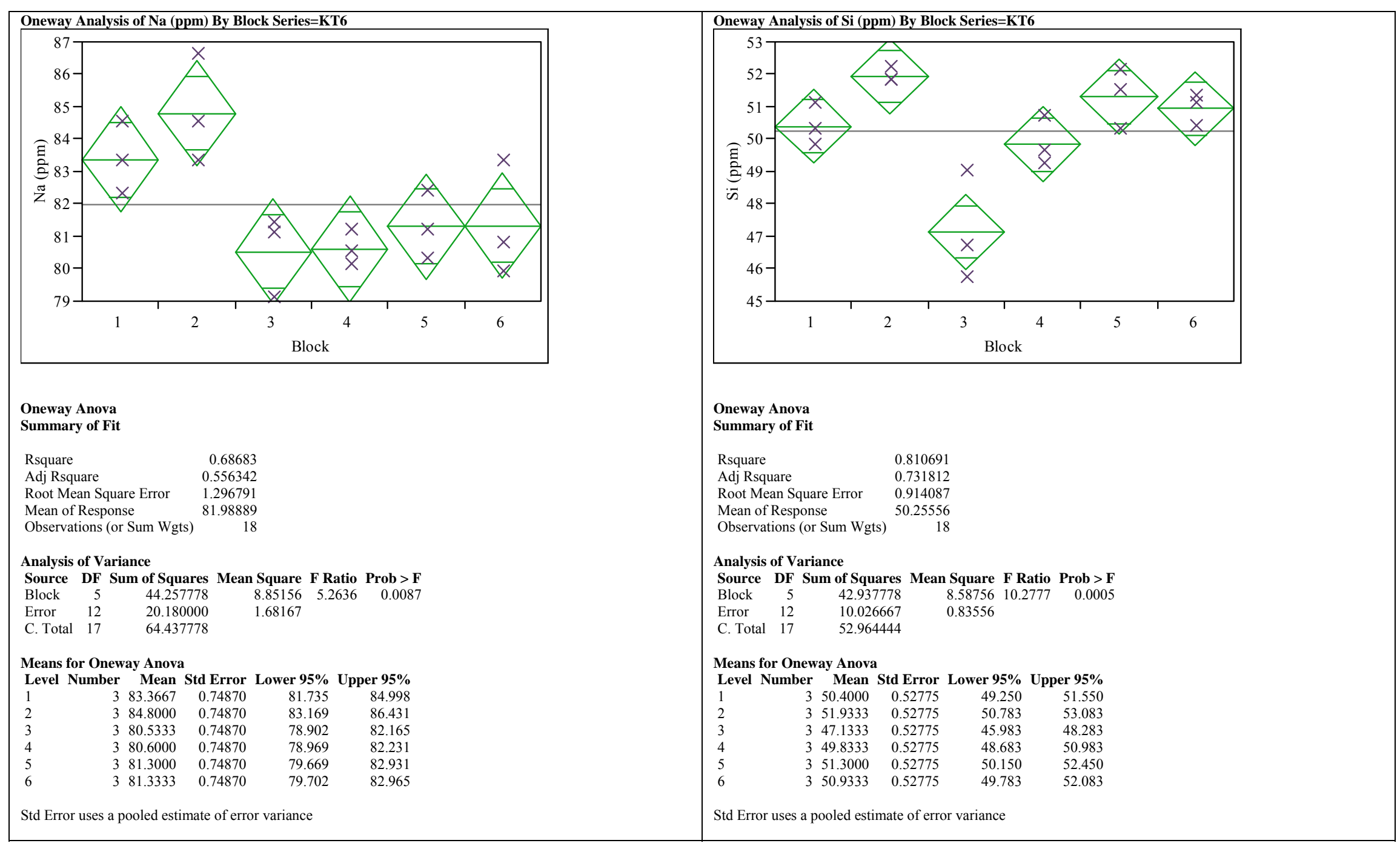




\section{Exhibit B-3. KT06 PCT Results (as common logarithms) Grouped by Glass ID and Heat Treatment.}

Variability Chart for log[B ppm]
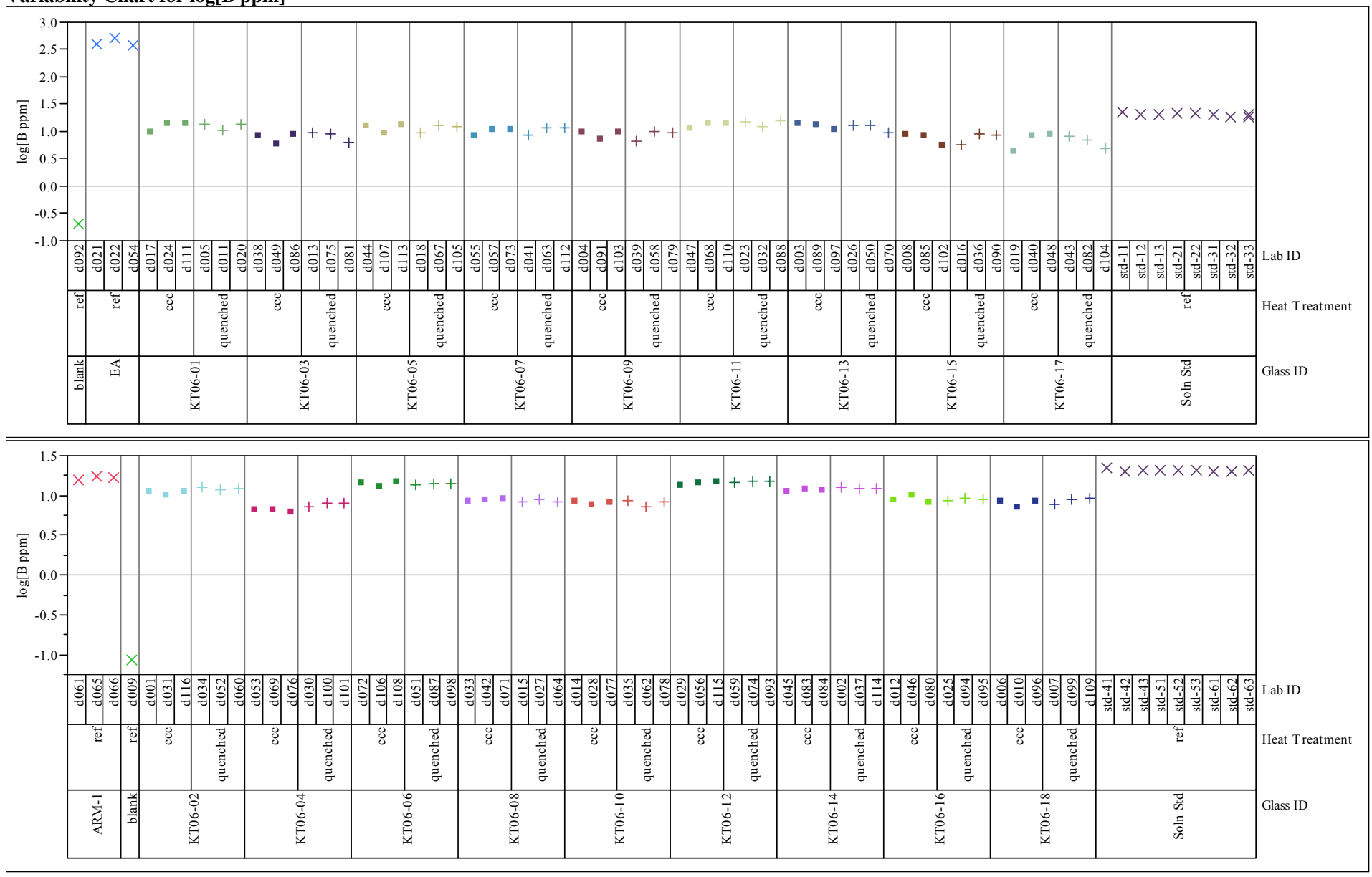
Exhibit B-3. KT06 PCT Results (as common logarithms) Grouped by Glass ID and Heat Treatment. (continued) Variability Chart for $\log [\mathrm{Li}$ ppm]
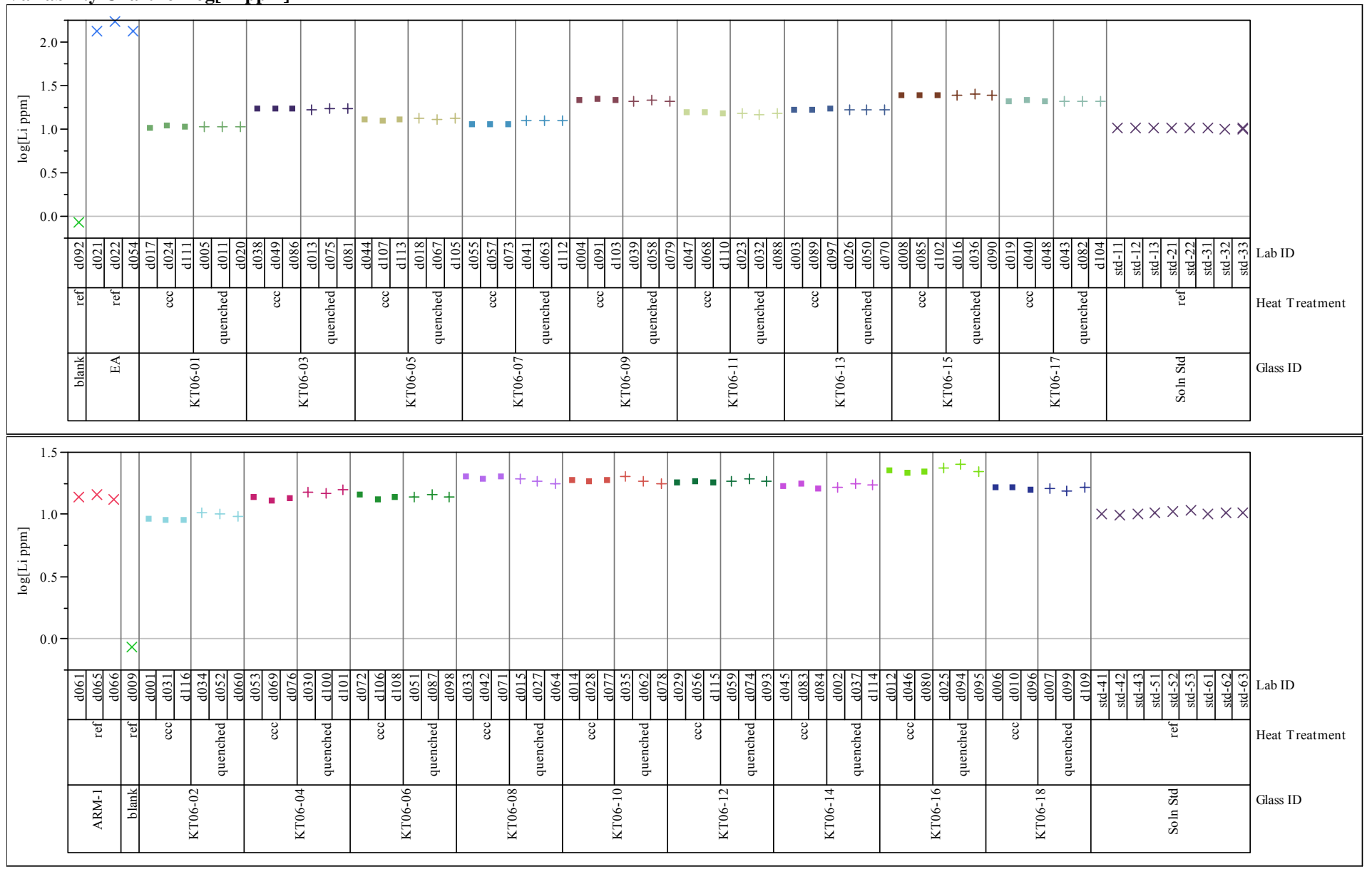
Exhibit B-3. KT06 PCT Results (as common logarithms) Grouped by Glass ID and Heat Treatment. (continued) Variability Chart for $\log [\mathrm{Na}$ ppm]
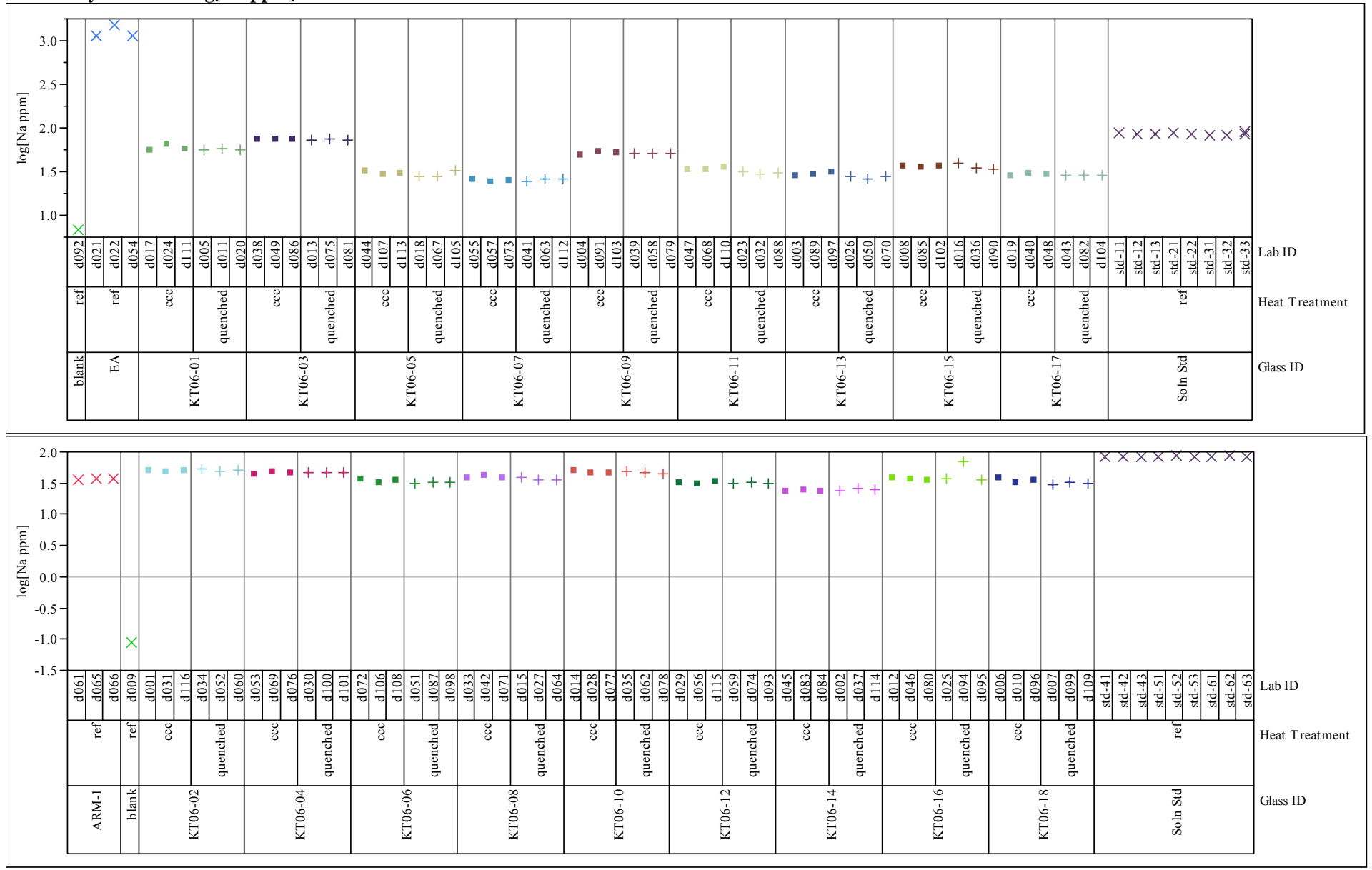
Exhibit B-3. KT06 PCT Results (as common logarithms) Grouped by Glass ID and Heat Treatment. (continued) Variability Chart for $\log [\mathrm{Si}$ ppm]
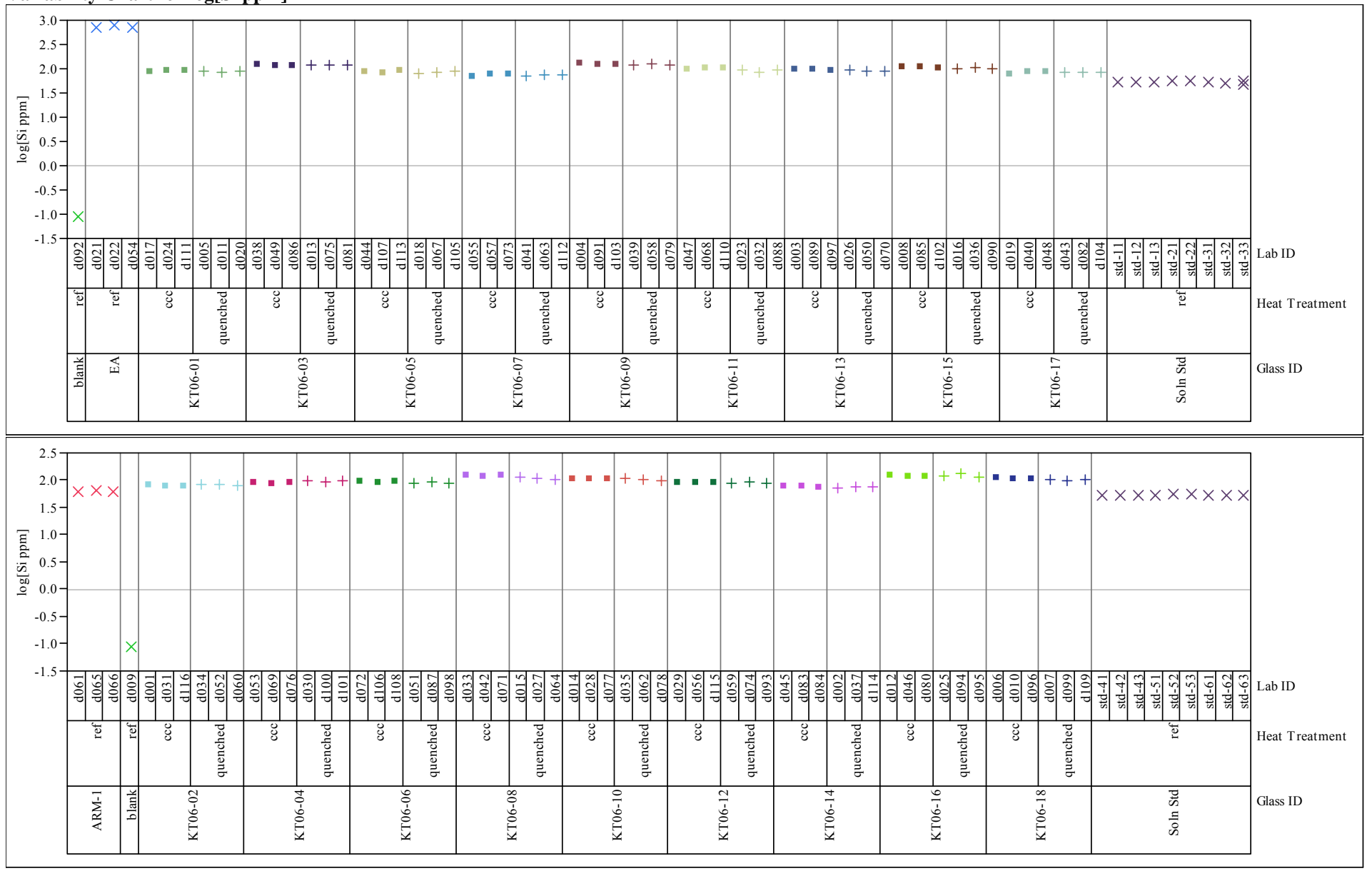


\section{Exhibit B-4. Correlations and Scatter Plots of the KT06 Normalized PCTs Over All} Compositional Views and Heat Treatments.

\section{Multivariate Correlations}

$\begin{array}{ccccc} & \log \mathbf{N L}[\mathbf{B}(\mathbf{g} / \mathbf{L})] & \log \mathbf{N L}[\mathbf{L i}(\mathbf{g} / \mathbf{L})] & \log \mathbf{N L}[\mathbf{N a}(\mathbf{g} / \mathbf{L})] & \log \text { NL[Si (g/L)] } \\ \log \text { NL[B }(\mathrm{g} / \mathrm{L})] & 1.0000 & 0.9733 & 0.8979 & 0.9447 \\ \log \mathrm{NL}[\mathrm{Li}(\mathrm{g} / \mathrm{L})] & 0.9733 & 1.0000 & 0.8744 & 0.9609 \\ \log \mathrm{NL}[\mathrm{Na}(\mathrm{g} / \mathrm{L})] & 0.8979 & 0.8744 & 1.0000 & 0.9113 \\ \log \text { NL[Si (g/L)] } & 0.9447 & 0.9609 & 0.9113 & 1.0000\end{array}$

\section{Scatterplot Matrix}

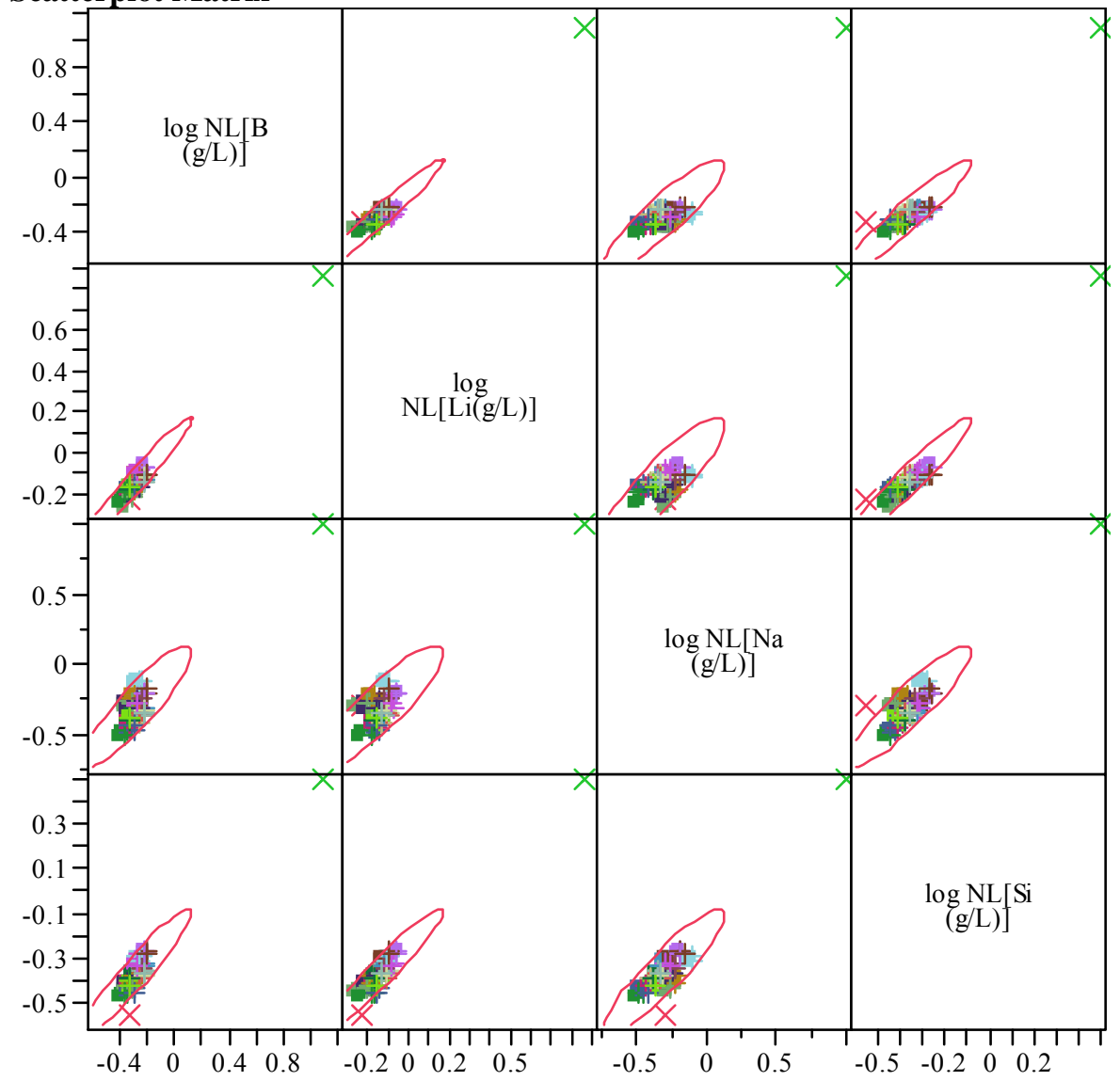


Exhibit B-5. Effects of Heat Treatment for the KT06 Glasses by Compositional View.

Variability Chart for log NL[B (g/L)]

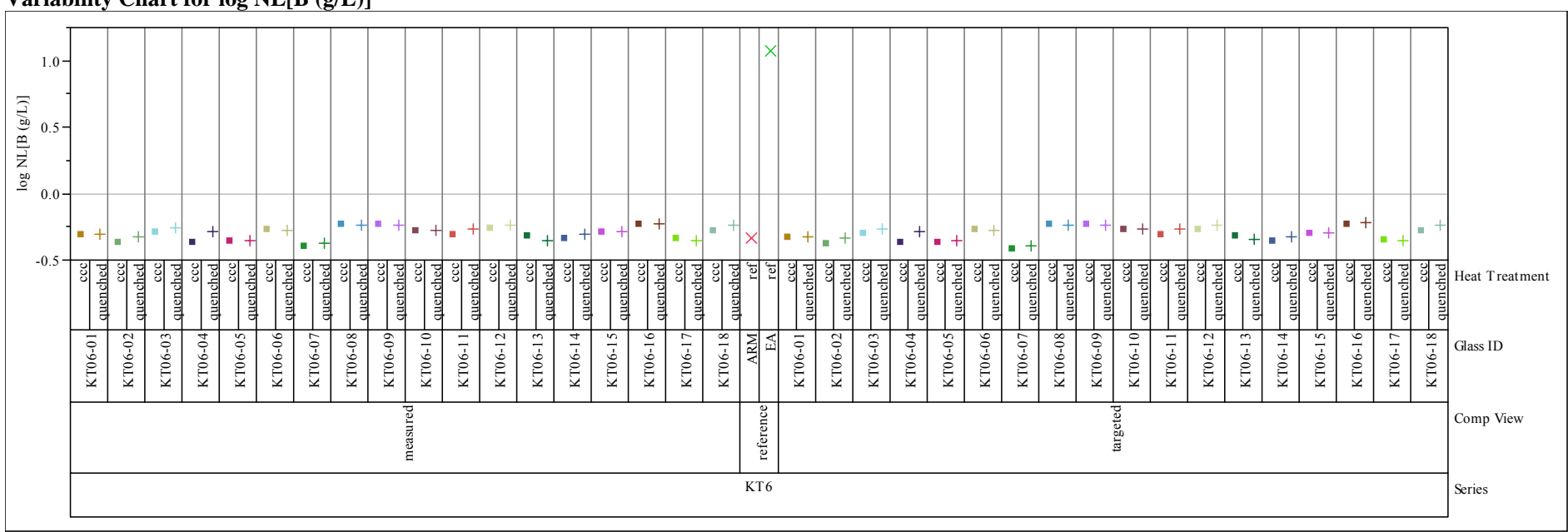

Variability Chart for $\log \mathrm{NL}[\mathrm{Li}(\mathrm{g} / \mathrm{L})]$

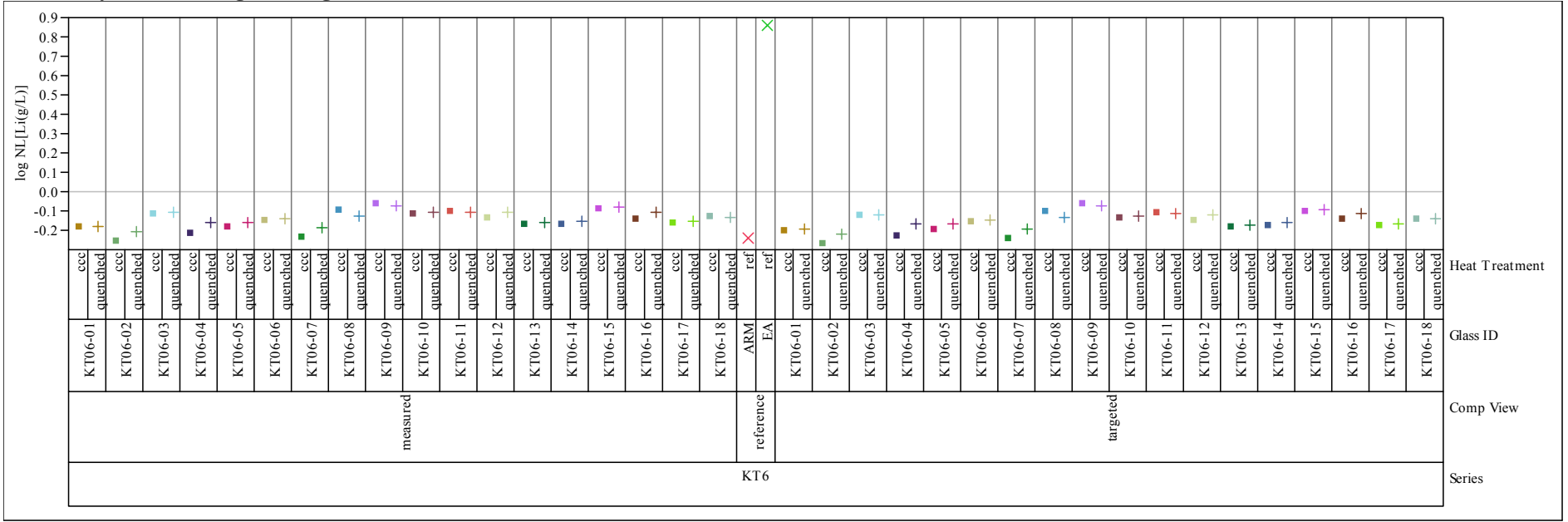


Exhibit B-5. Effects of Heat Treatment for the KT06 Glasses by Compositional View. (continued)

Variability Chart for $\log N L[N a(g / L)]$

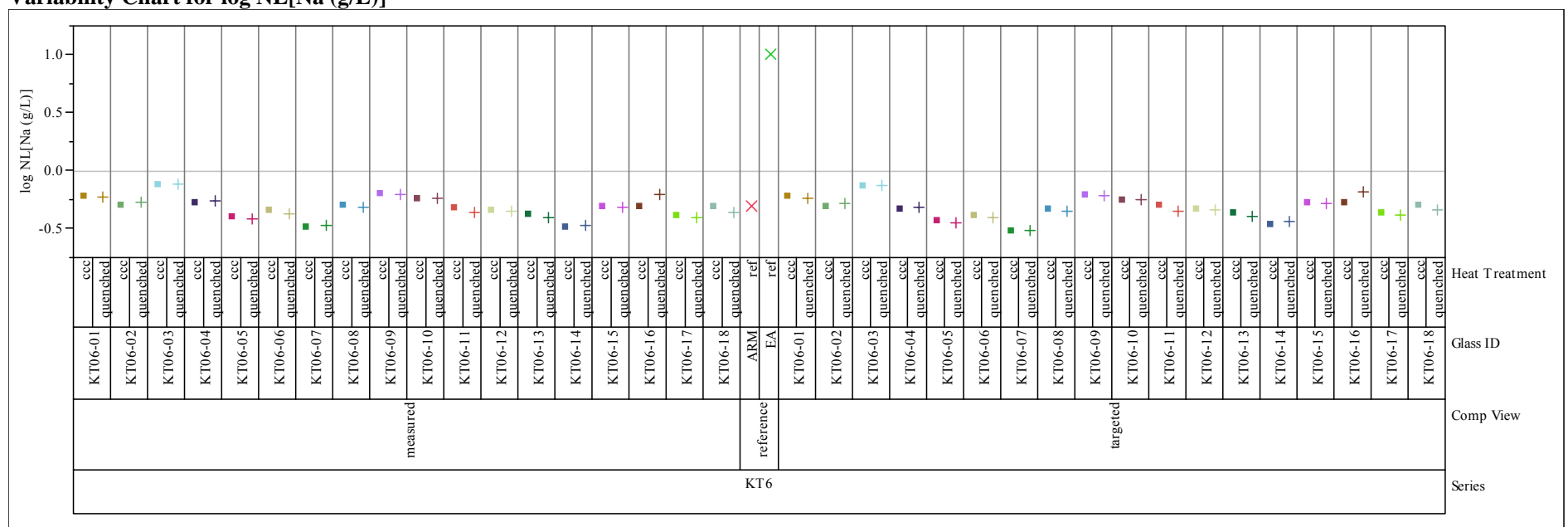

Variability Chart for log NL[Si (g/L)]

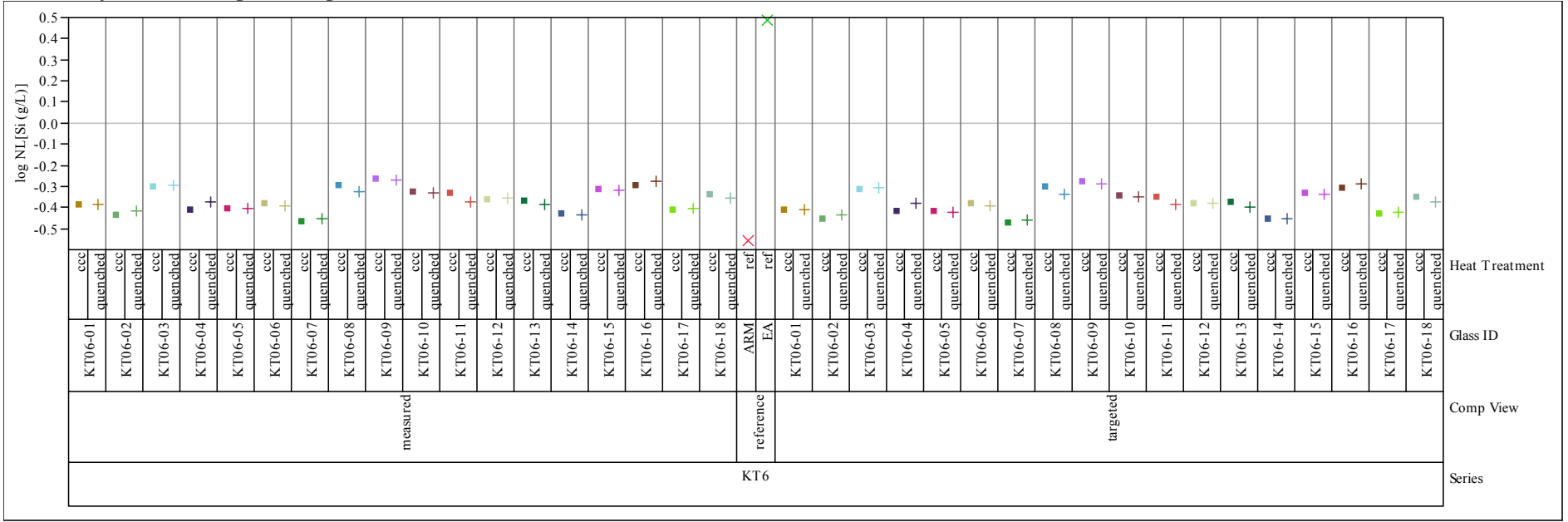


Exhibit B-6. PCT Measurements versus Durability Model Predictions.
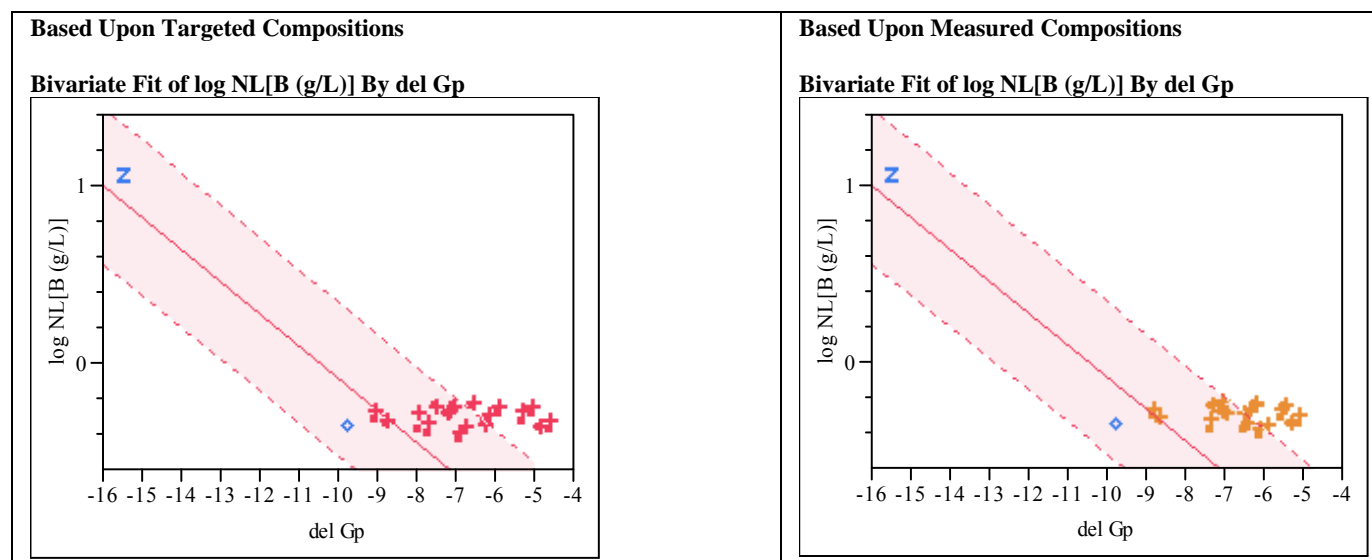

Bivariate Fit of log NL[Li (g/L)] By del Gp

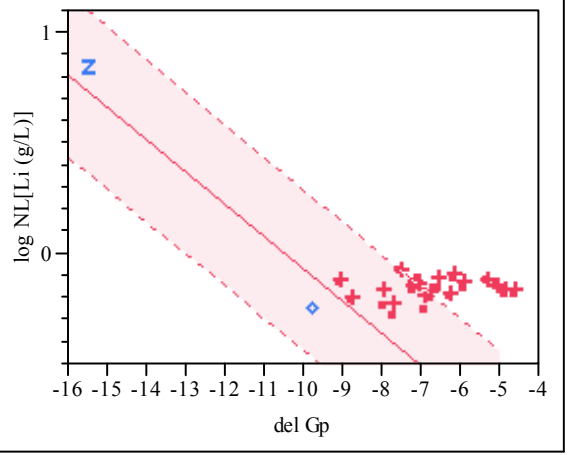

Bivariate Fit of $\log \mathrm{NL}[\mathrm{Na}(\mathrm{g} / \mathrm{L})]$ By del Gp

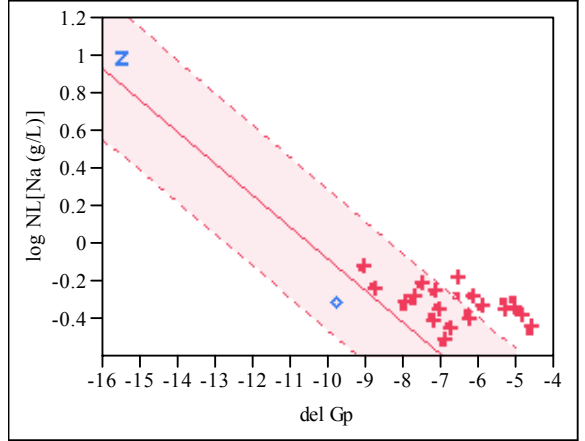

Bivariate Fit of log NL[Si (g/L)] By del Gp

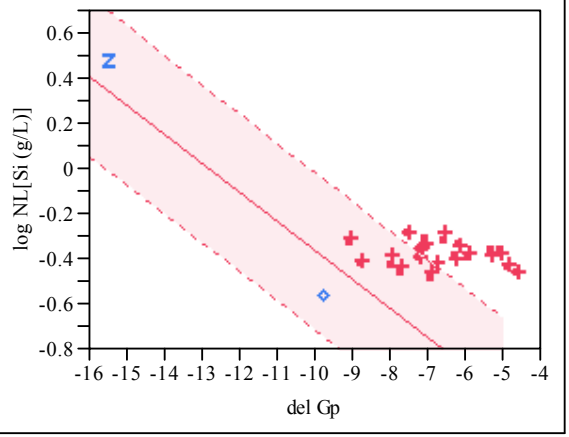

Bivariate Fit of $\log N L[\mathrm{Li}(\mathrm{g} / \mathrm{L})]$ By del Gp

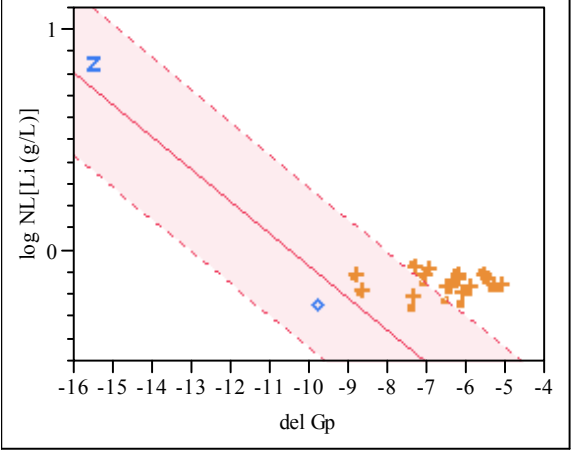

Bivariate Fit of $\log$ NL[Na (g/L)] By del Gp

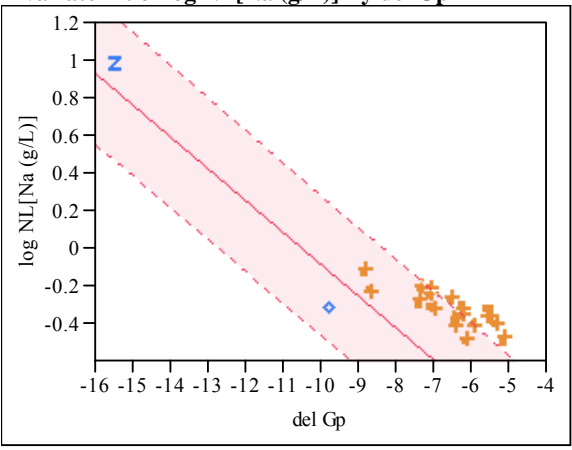

Bivariate Fit of $\log$ NL[Si (g/L)] By del Gp

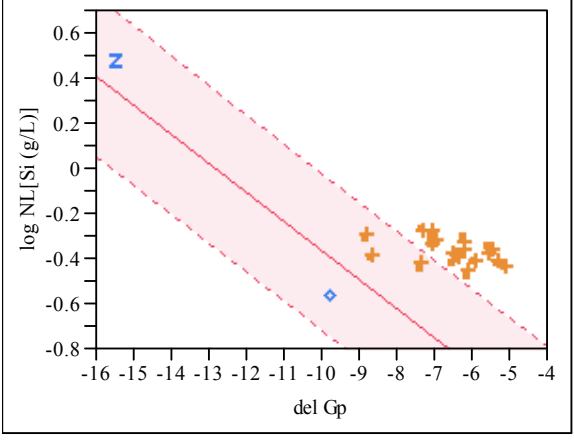




\section{Exhibit B-7. PCT Measurements versus Durability Model Predictions} for Amorphous Glasses Only.

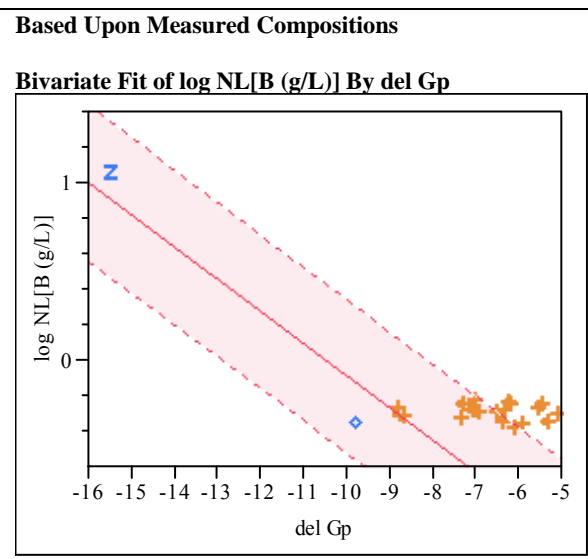

Bivariate Fit of $\log$ NL[Li (g/L)] By del Gp

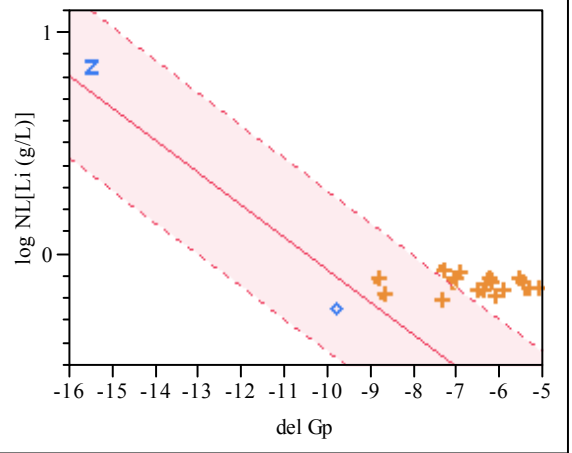

Bivariate Fit of $\log \mathrm{NL}[\mathrm{Na}(\mathrm{g} / \mathrm{L})]$ By del Gp

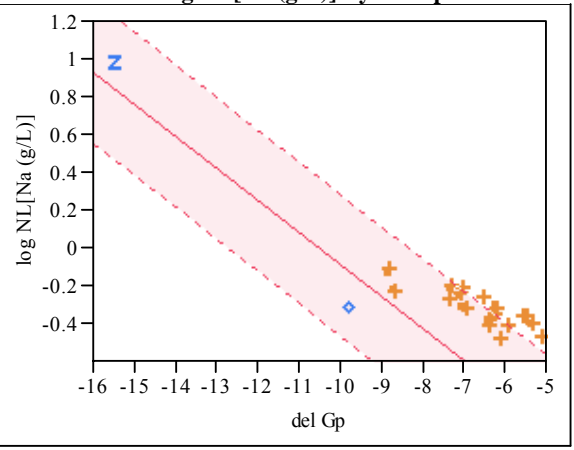

Bivariate Fit of log NL[Si (g/L)] By del Gp

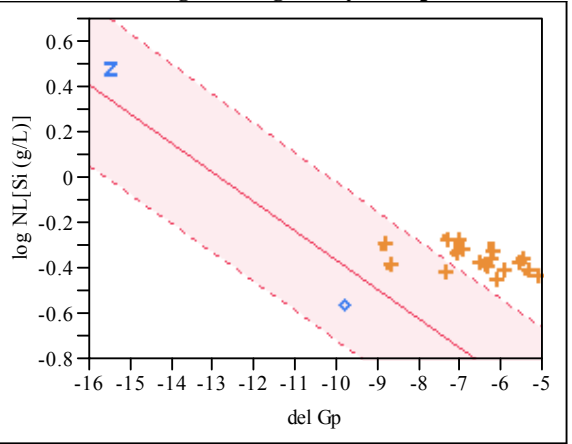


Appendix C. Results from Fitting Fulcher Equations to the Viscosity Measurements for the KT06 Glasses 


\section{Exhibit C-1. Results from Fitting Fulcher Equations to the Viscosity Measurements of the KT01-Series Glasses.}

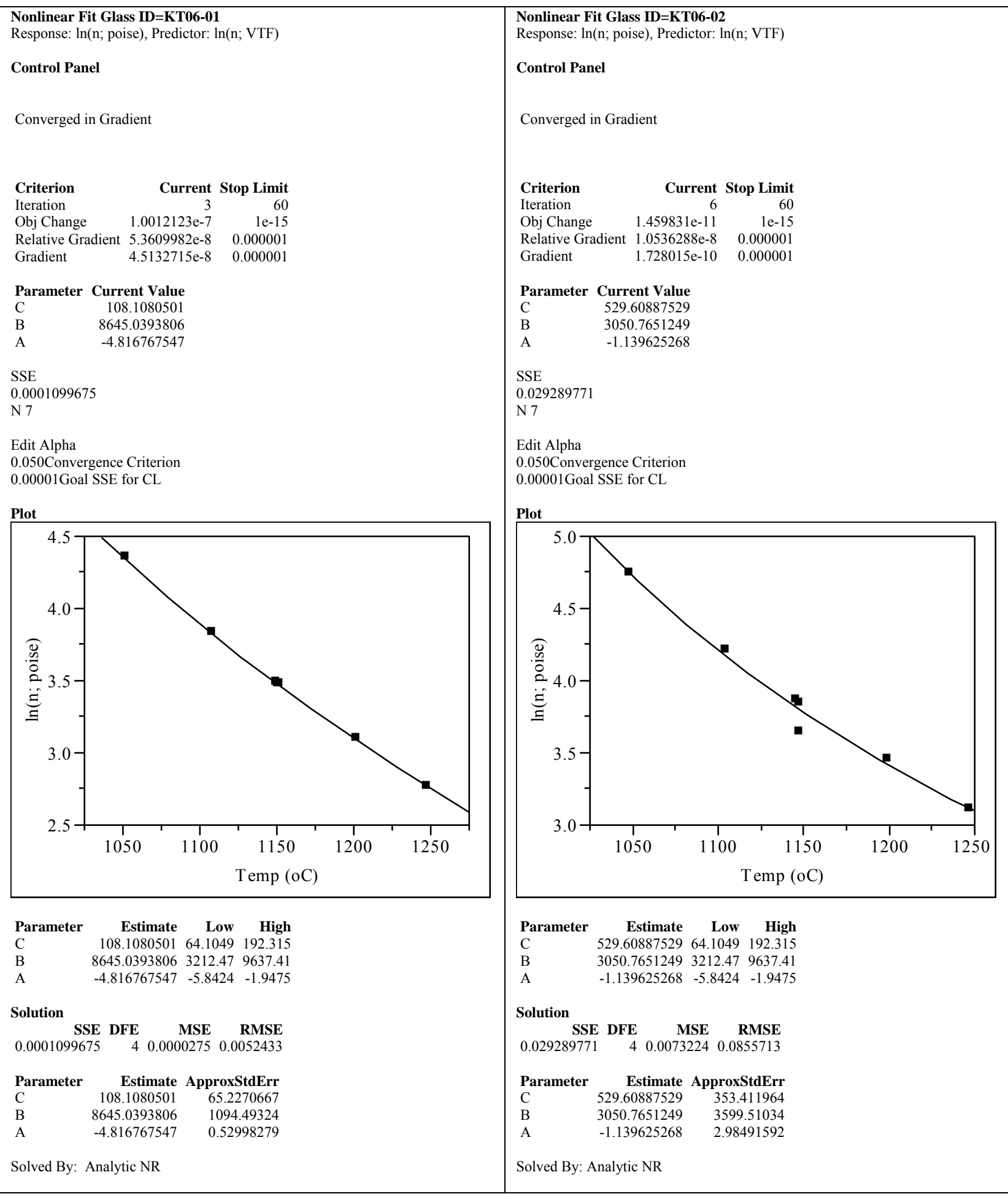




\section{Exhibit C-1. Results from Fitting Fulcher Equations to the Viscosity Measurements of the KT01-Series Glasses. (continued)}

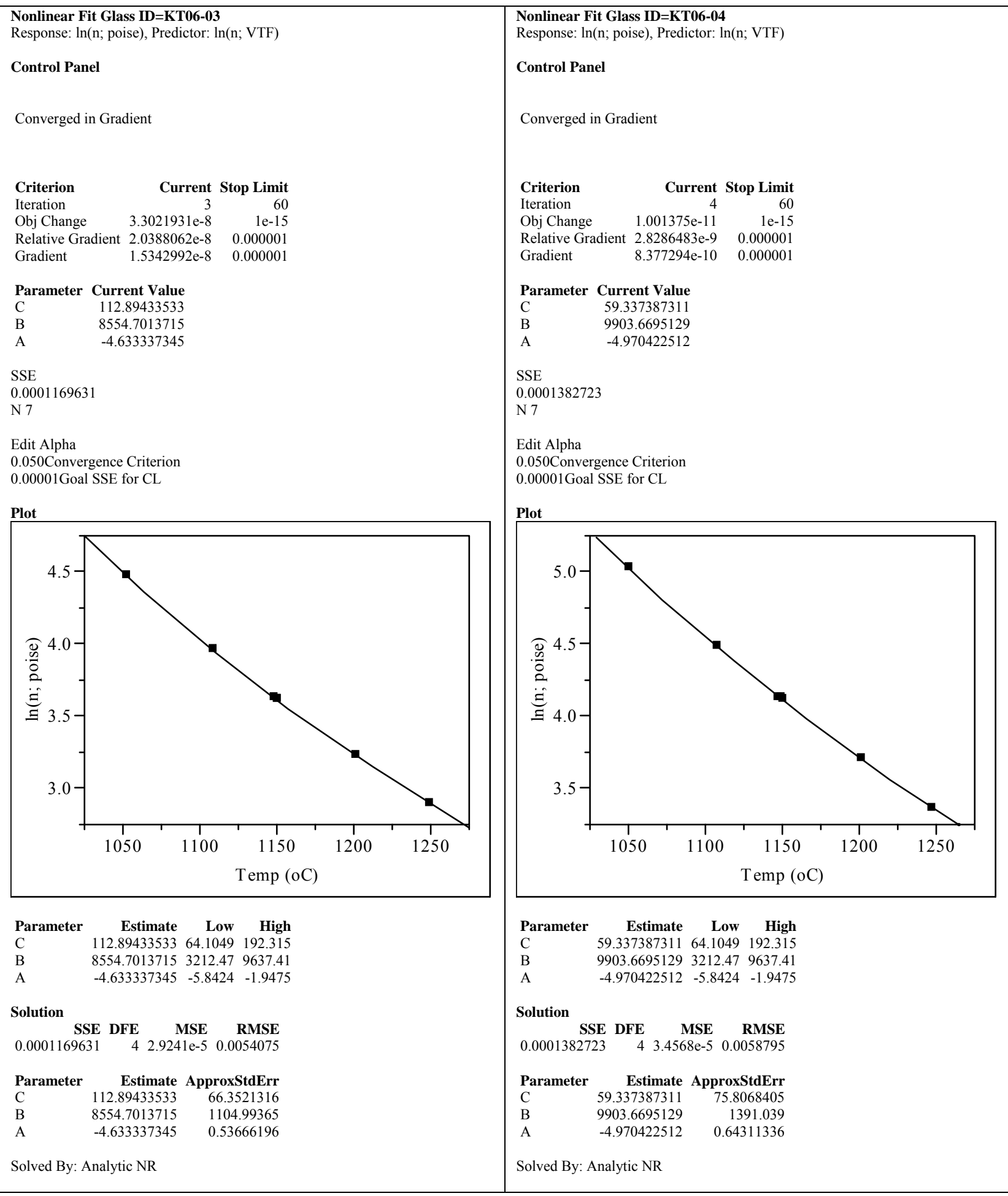




\section{Exhibit C-1. Results from Fitting Fulcher Equations to the Viscosity Measurements of the KT01-Series Glasses. (continued)}

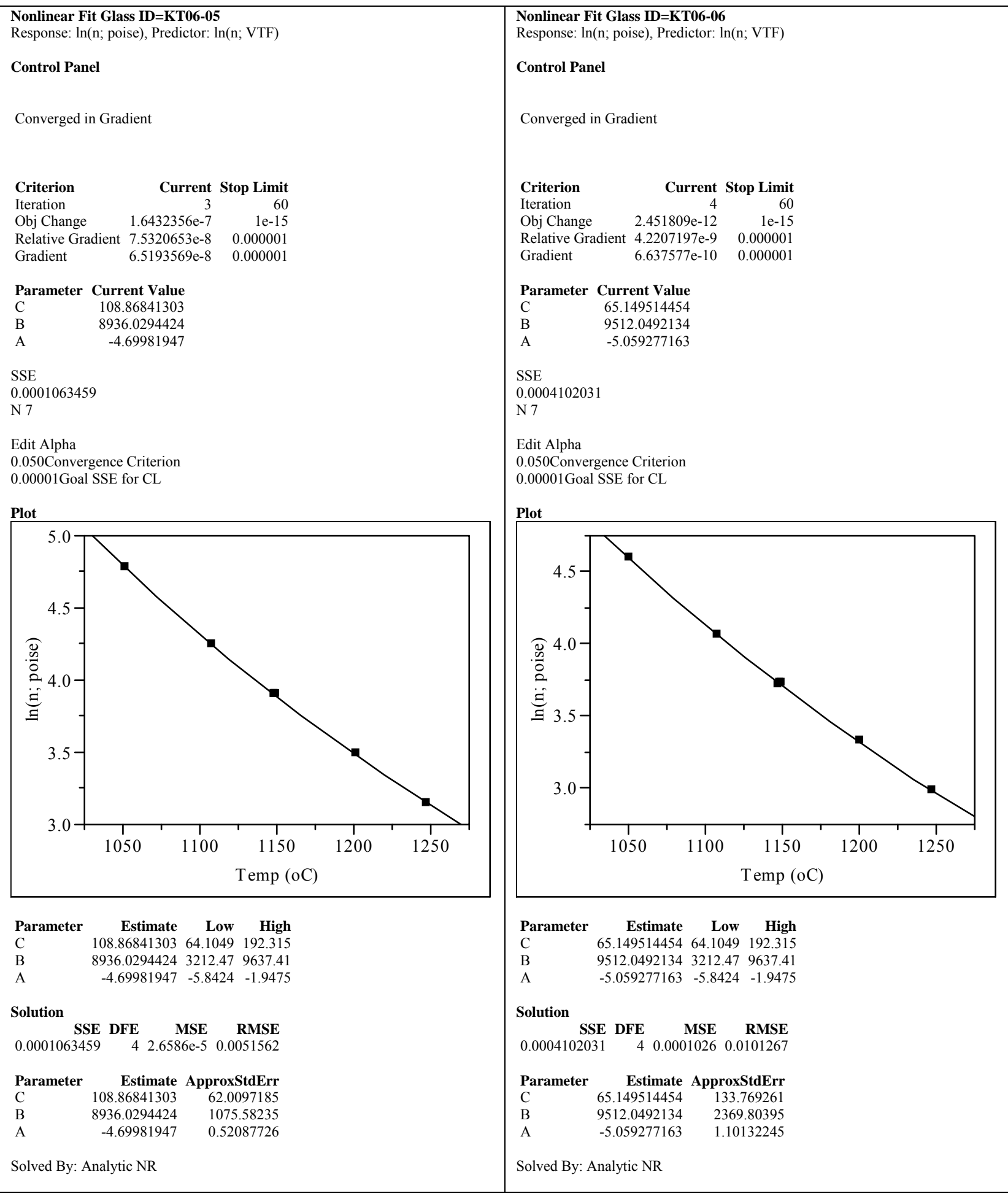




\section{Exhibit C-1. Results from Fitting Fulcher Equations to the Viscosity Measurements of the KT01-Series Glasses. (continued)}

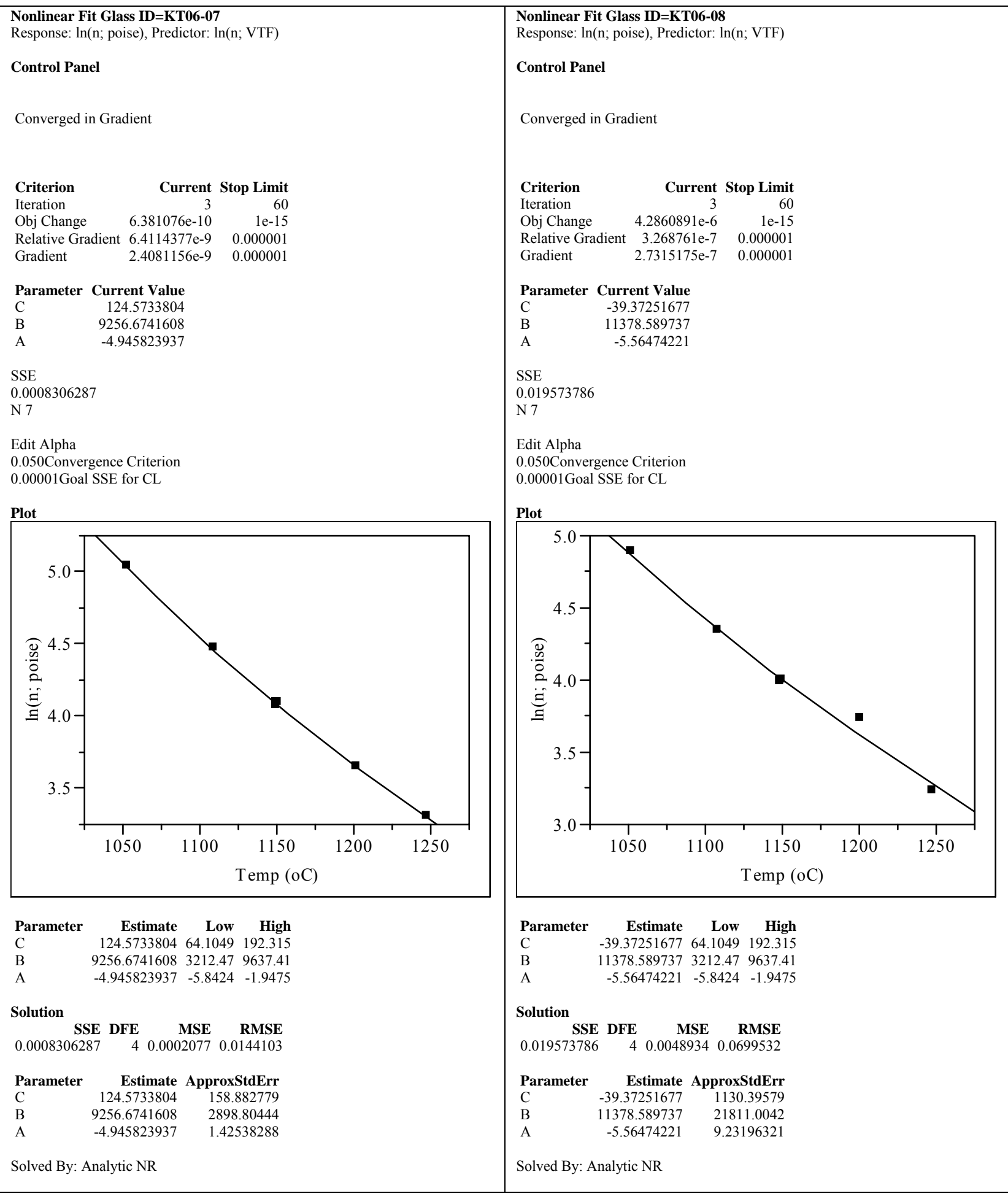




\section{Exhibit C-1. Results from Fitting Fulcher Equations to the Viscosity Measurements of the KT01-Series Glasses. (continued)}

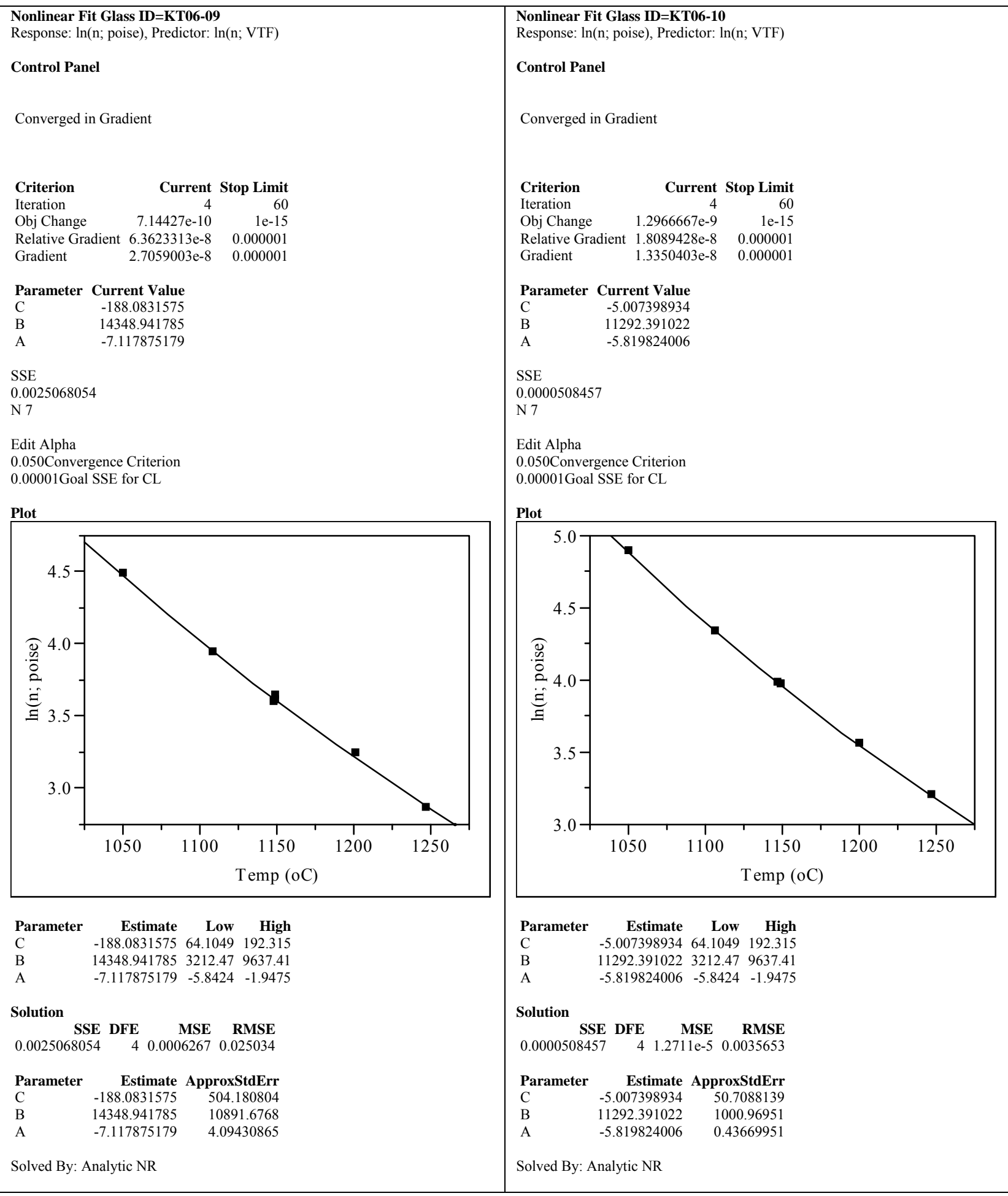




\section{Exhibit C-1. Results from Fitting Fulcher Equations to the Viscosity Measurements of the KT01-Series Glasses. (continued)}

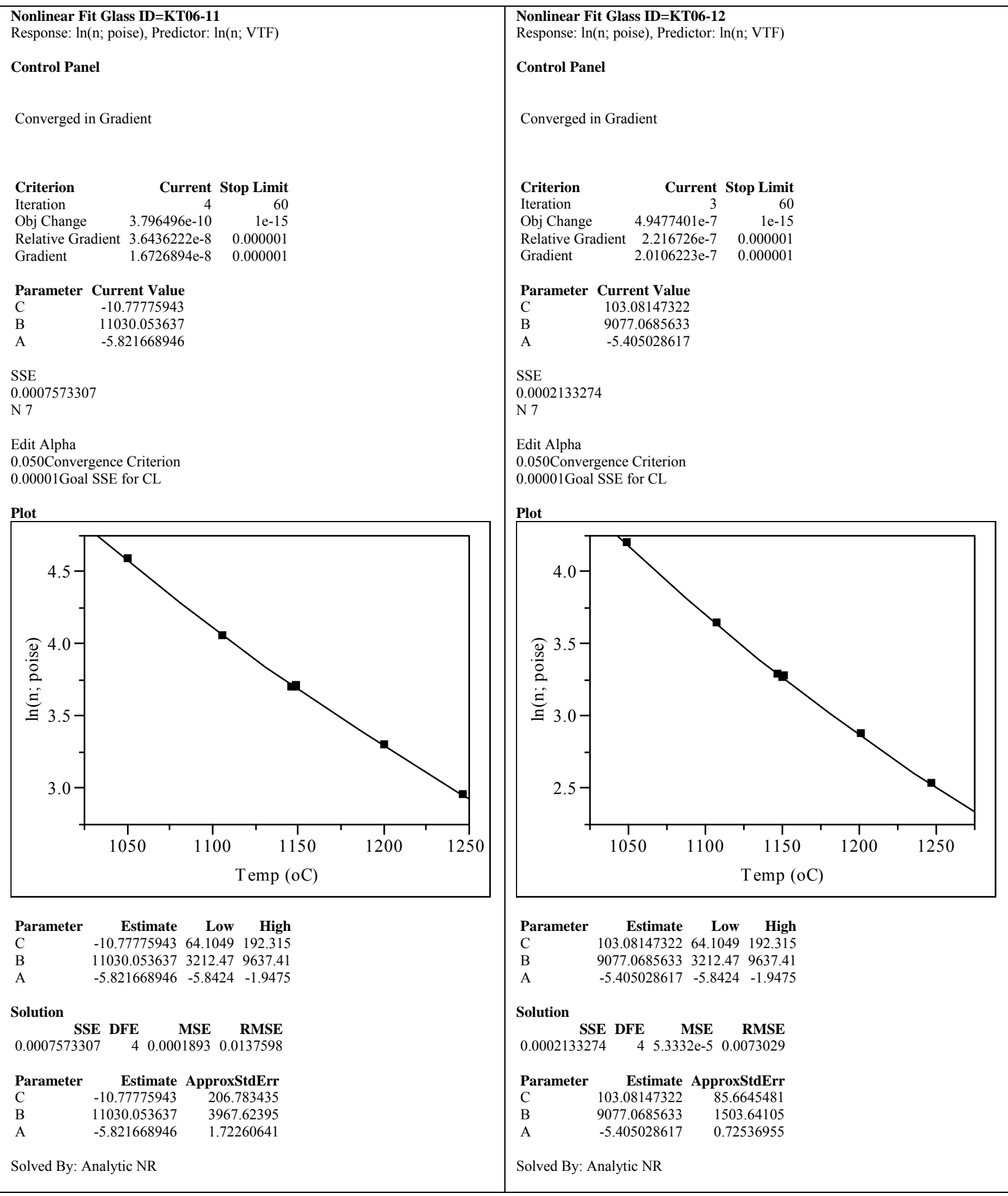




\section{Exhibit C-1. Results from Fitting Fulcher Equations to the Viscosity Measurements of the KT01-Series Glasses. (continued)}

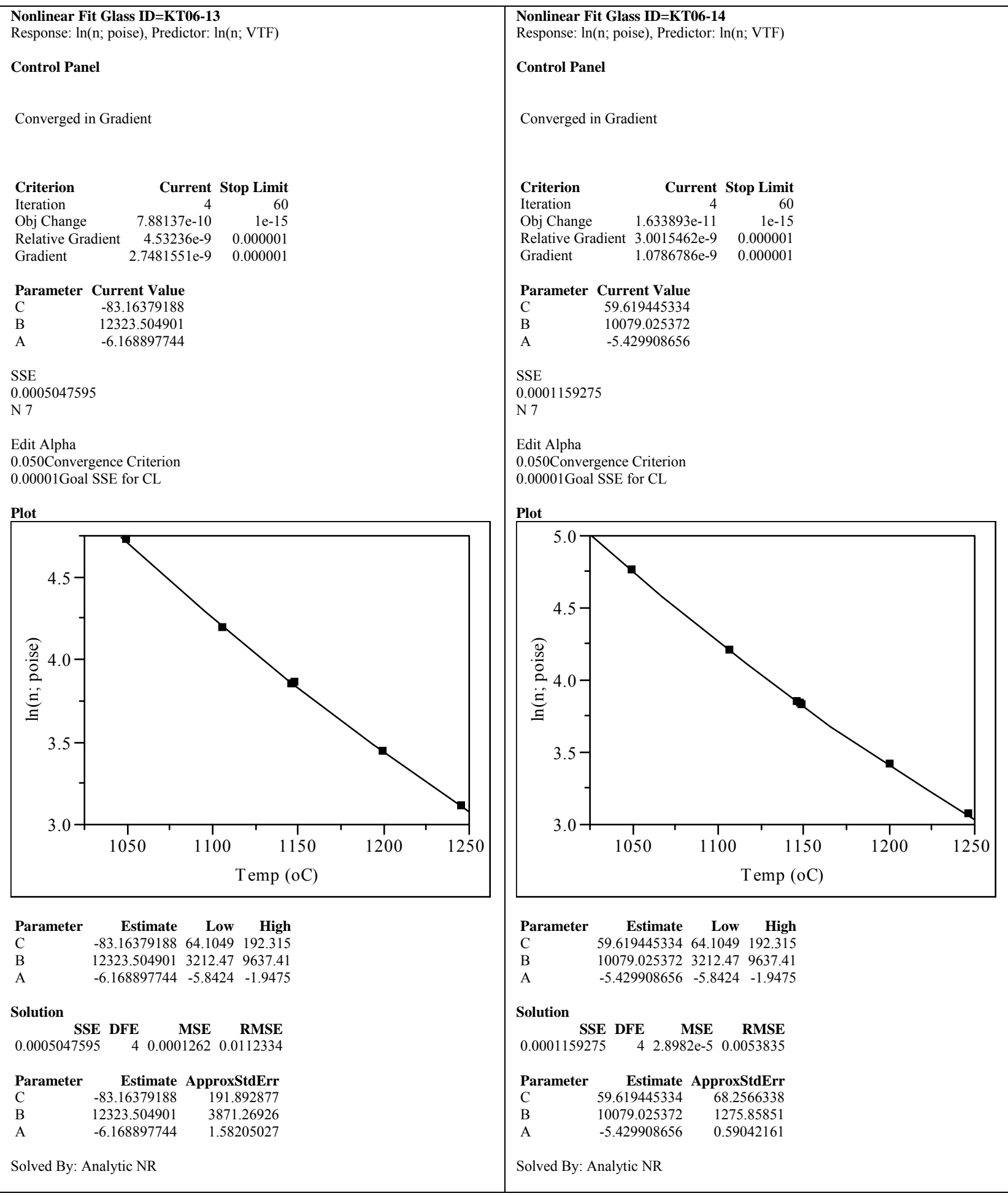




\section{Exhibit C-1. Results from Fitting Fulcher Equations to the Viscosity Measurements of the KT01-Series Glasses. (continued)}

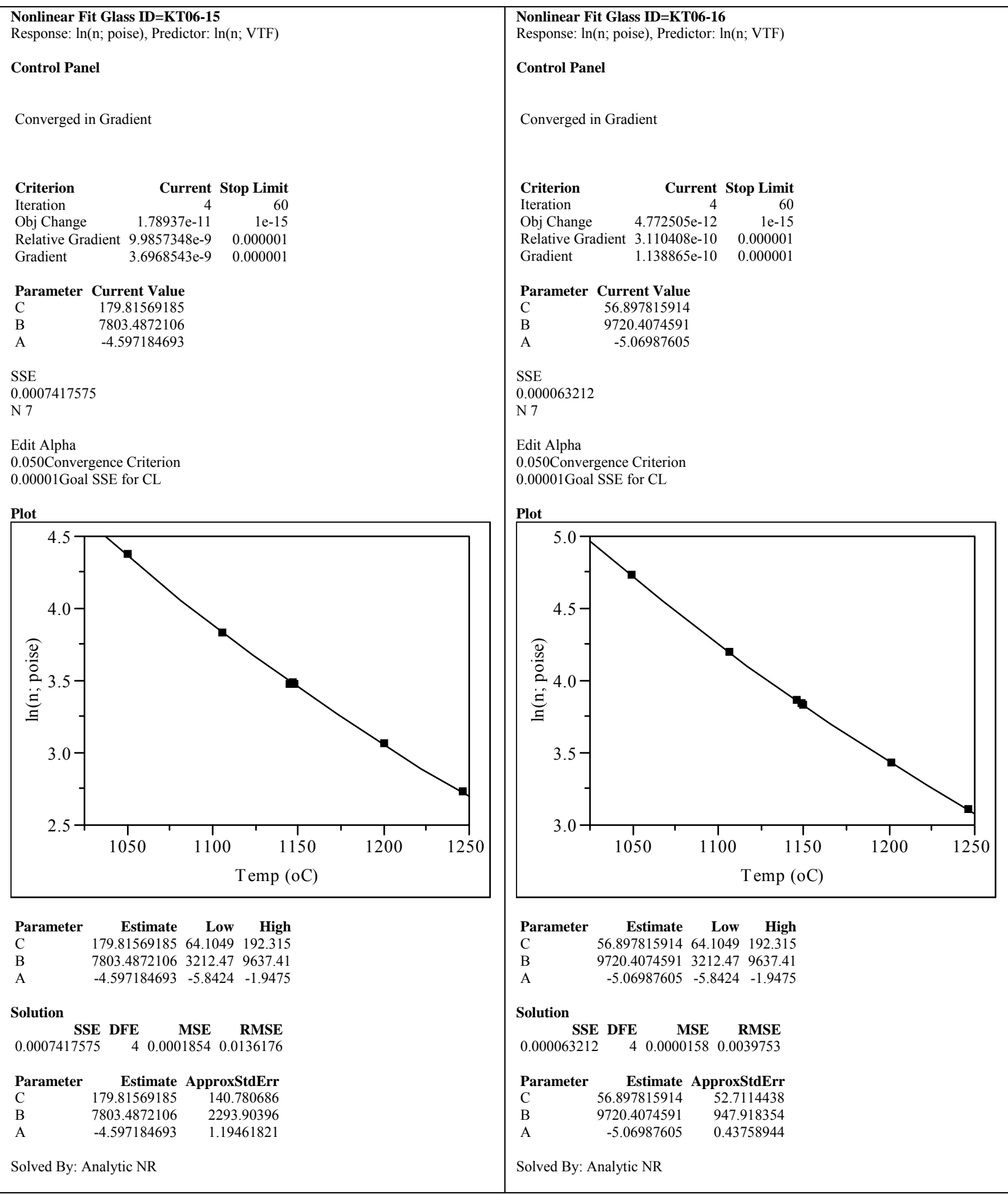




\section{Exhibit C-1. Results from Fitting Fulcher Equations to the Viscosity Measurements of the KT01-Series Glasses. (continued)}

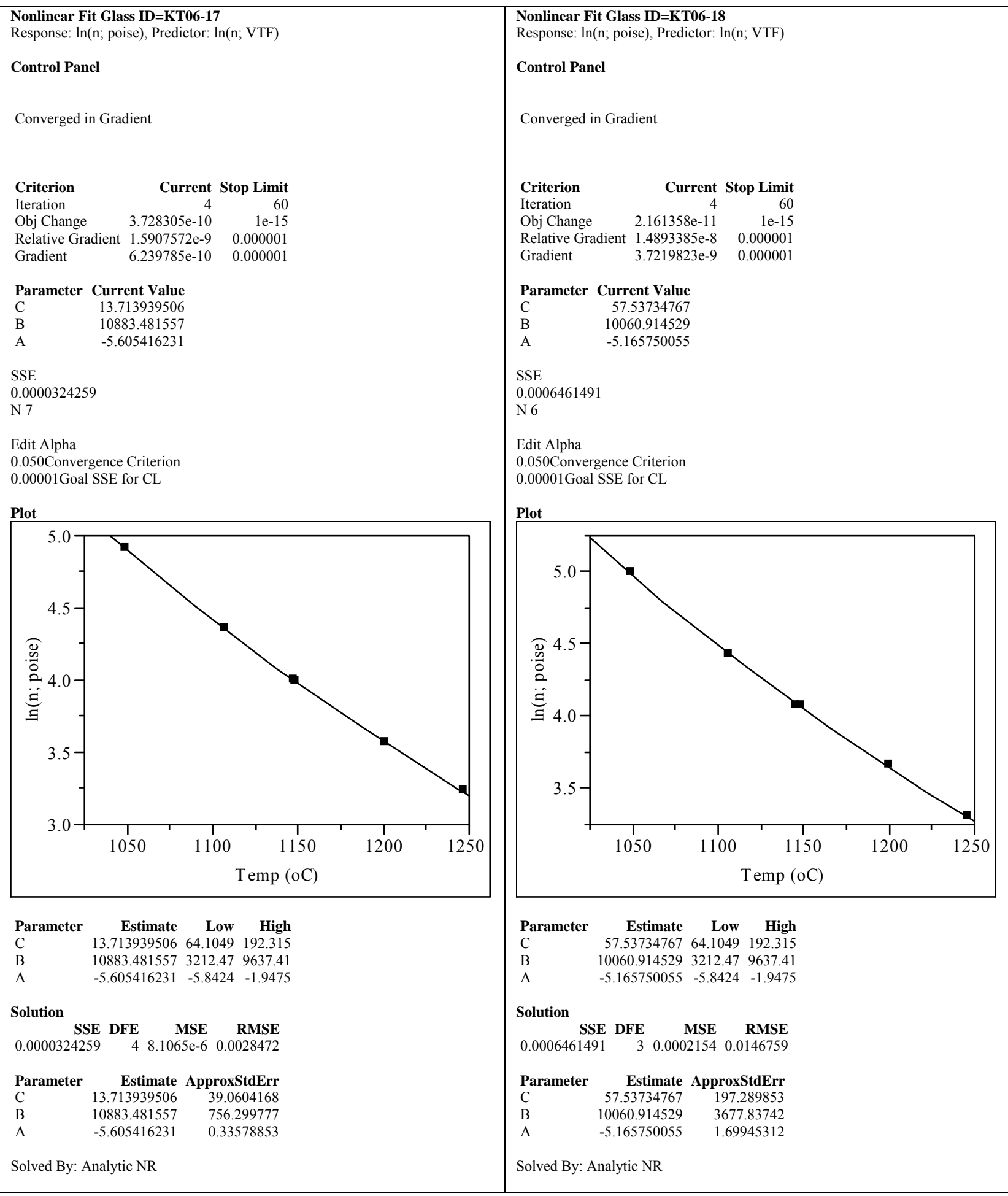


Exhibit C-2. Model Predicted Viscosities with Confidence Intervals (CI) and

Measured Viscosities (Fulcher Fits) at $1150{ }^{\circ} \mathrm{C}$ for the KT06-Series Glasses by Compositional View.

\begin{tabular}{|c|c|c|c|c|c|c|}
\hline $\begin{array}{c}\text { Compositional } \\
\text { View }\end{array}$ & Glass ID & $\begin{array}{c}\text { Viscosity } \\
\text { Prediction (P) }\end{array}$ & $\begin{array}{c}\text { Lower CI for } \\
\text { Prediction (P) }\end{array}$ & $\begin{array}{l}\text { Upper CI for } \\
\text { Prediction (P) }\end{array}$ & $\begin{array}{c}\text { Meas. Visc. } \\
\text { (Fulcher) (P) }\end{array}$ & $\begin{array}{c}\text { Model } \\
\text { Predictable? }\end{array}$ \\
\hline measured & KT06-01 & 44.58 & 30.41 & 65.37 & 32.48 & yes \\
\hline measured & KT06-02 & 73.29 & 50.01 & 107.41 & 43.72 & no \\
\hline measured & KT06-03 & 49.00 & 33.42 & 71.83 & 37.16 & yes \\
\hline measured & KT06-04 & 93.93 & 64.08 & 137.69 & 60.95 & no \\
\hline measured & KT06-05 & 56.41 & 38.49 & 82.68 & 48.58 & yes \\
\hline measured & KT06-06 & 47.65 & 32.50 & 69.86 & 40.8 & yes \\
\hline measured & KT06-07 & 92.04 & 62.79 & 134.90 & 59.22 & no \\
\hline measured & KT06-08 & 61.14 & 41.72 & 89.61 & 54.72 & yes \\
\hline measured & KT06-09 & 42.21 & 28.78 & 61.90 & 36.8 & yes \\
\hline measured & KT06-10 & 77.09 & 52.61 & 112.98 & 52.3 & no \\
\hline measured & KT06-11 & 43.91 & 29.94 & 64.38 & 39.67 & yes \\
\hline measured & KT06-12 & 33.63 & 22.92 & 49.35 & 26.19 & yes \\
\hline measured & KT06-13 & 78.15 & 53.32 & 114.53 & 45.81 & no \\
\hline measured & KT06-14 & 63.54 & 43.35 & 93.11 & 45.32 & yes \\
\hline measured & KT06-15 & 32.97 & 22.47 & 48.39 & 31.38 & yes \\
\hline measured & KT06-16 & 71.88 & 49.05 & 105.34 & 45.72 & no \\
\hline measured & KT06-17 & 66.39 & 45.30 & 97.30 & 53.13 & yes \\
\hline measured & KT06-18 & 57.93 & 39.53 & 84.91 & 57.03 & yes \\
\hline targeted & KT06-01 & 48.12 & 32.82 & 70.55 & 32.48 & no \\
\hline targeted & KT06-02 & 72.43 & 49.42 & 106.14 & 43.72 & no \\
\hline targeted & KT06-03 & 50.58 & 34.51 & 74.15 & 37.16 & yes \\
\hline targeted & KT06-04 & 74.74 & 51.00 & 109.54 & 60.95 & yes \\
\hline targeted & KT06-05 & 53.78 & 36.69 & 78.83 & 48.58 & yes \\
\hline targeted & KT06-06 & 41.85 & 28.54 & 61.37 & 40.8 & yes \\
\hline targeted & KT06-07 & 77.88 & 53.14 & 114.13 & 59.22 & yes \\
\hline targeted & KT06-08 & 56.27 & 38.39 & 82.48 & 54.72 & yes \\
\hline targeted & KT06-09 & 44.32 & 30.23 & 64.98 & 36.8 & yes \\
\hline targeted & KT06-10 & 80.11 & 54.67 & 117.41 & 52.3 & no \\
\hline targeted & KT06-11 & 50.14 & 34.21 & 73.50 & 39.67 & yes \\
\hline targeted & KT06-12 & 38.53 & 26.27 & 56.51 & 26.19 & no \\
\hline targeted & KT06-13 & 81.79 & 55.81 & 119.87 & 45.81 & no \\
\hline targeted & KT06-14 & 73.45 & 50.12 & 107.65 & 45.32 & no \\
\hline targeted & KT06-15 & 41.08 & 28.01 & 60.25 & 31.38 & yes \\
\hline targeted & KT06-16 & 83.85 & 57.22 & 122.90 & 45.72 & no \\
\hline targeted & KT06-17 & 75.84 & 51.75 & 111.14 & 53.13 & yes \\
\hline targeted & KT06-18 & 66.21 & 45.18 & 97.03 & 57.03 & yes \\
\hline
\end{tabular}


Exhibit C-3. KT06-Series Measured Versus Predicted Viscosity Values Based on Measured and Target Compositions.

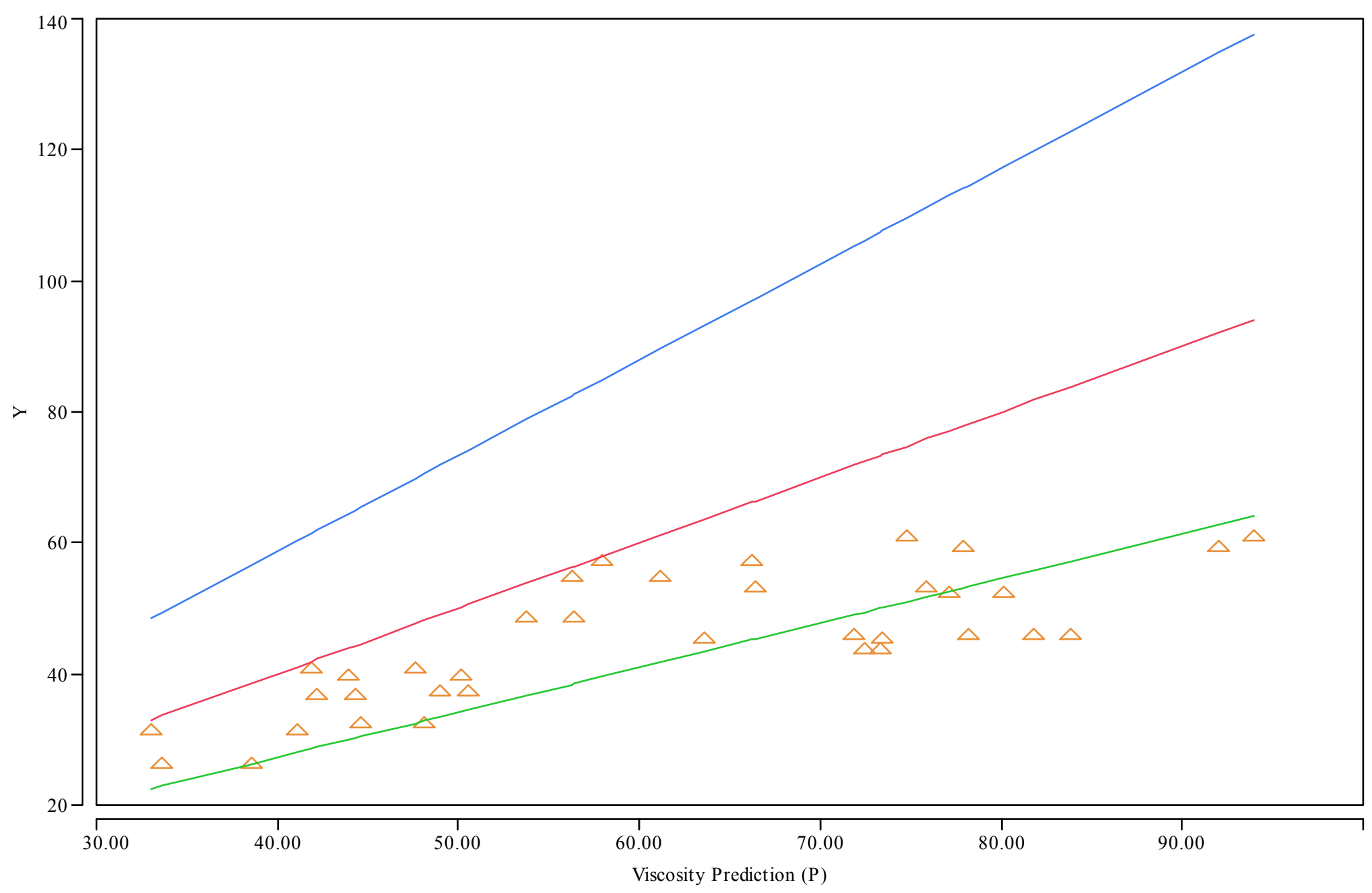

$\mathrm{Y}$ —Viscosity Prediction (P) — Lower CI for Ind. $\quad$ - Upper CI for Ind. $\quad \therefore$ Visc Meas (Fulcher) (P) 


\section{Distribution:}

J. W. Amoroso, 999-W

C. J. Bannochie, 773-42A

A. B. Barnes, 999-W

A. L. Billings, 999-W

J. M. Bricker, 704-27S

M. A. Broome, 704-29S

C. L. Crawford, 773-42A

D. A. Crowley, 773-43A

R. E. Edwards, 766-H

T. B. Edwards, 999-W

A. P. Fellinger, 773-41A

T. L. Fellinger, 704-26S

S. D. Fink, 773-A

K. M. Fox, 999-W

B. J. Giddings, 786-5A

J. M. Gillam, 766-H

B. A. Hamm, 766-H

C. C. Herman, 999-W

D. T. Herman, 735-11A

R. N. Hinds, 704-S

E. W. Holtzscheiter, 704-15S

T. H. Huff, 766-H
J. F. Iaukea, 704-30S

P. R. Jackson, 703-46A

C. M. Jantzen, 773-A

F. C. Johnson, 999-W

D. C. Koopman, 999-W

D. D. Larsen, 766-H

T. E. Laupa, 766-H

P. L. Lee, 703-41A

S. L. Marra, 773-A

D. H. Miller, 999-W

J. E. Occhipinti, 704-S

D. K. Peeler, 999-W

F. M. Pennebaker, 773-42A

J. W. Ray, 704-S

M. A. Rios-Armstrong, 766-H

H. B. Shah, 766-H

D. C. Sherburne, 704-S

A. V. Staub, 704-27S

M. E. Stone, 999-W

J. P. Vaughan, 773-41A

W. R. Wilmarth, 773-A 